\author{
Mon ograph \\ urn:1sid:zoobank.org:pub:226B6C59-8620-4A29-9BEF-359BE67A1A2C
}

\title{
The Changhsingian (Late Permian) ammonoids from Baghuk Mountain (Central Iran)
}

\author{
Dieter KORN ${ }^{1, *}$, Vachik HAIRAPETIAN ${ }^{2}$, Abbas GHADERI ${ }^{3}$, Lucyna LEDA ${ }^{4}$, \\ Martin SCHOBBEN ${ }^{5} \&$ Amir AKBARI ${ }^{6}$ \\ ${ }^{1,4}$ Museum für Naturkunde, Leibniz Institut for Research on Evolution and Biodiversity, \\ Invalidenstraße 43, 10115 Berlin, Germany. \\ ${ }^{2,6}$ Department of Geology, Esfahan (Khorasgan) Branch, Islamic Azad University, Esfahan, Iran. \\ ${ }^{3}$ Department of Geology, Faculty of Science, Ferdowsi University of Mashhad, \\ Azadi Square, 9177948974, Mashhad, Iran. \\ ${ }^{5}$ Utrecht University, Department of Earth Sciences, Princetonlaan 8A, \\ 3584 CB Utrecht, The Netherlands. \\ *Corresponding author: dieter.korn@mfn.berlin \\ ${ }^{2}$ Email: vhairap@gmail.com \\ ${ }^{3}$ Email: aghaderi@um.ac.ir \\ [4Email: lucyna.skorpion3@wp.pl \\ ${ }^{5}$ Email: schobbenmartin@gmail.com \\ ${ }^{6}$ Email: amakbari80@yahoo.com \\ ${ }^{1}$ urn:1sid:zoobank.org:author:286CA4F3-7EBC-4AEF-A66A-B2508D001367 \\ ${ }^{2}$ urn:lsid:zoobank.org:author:1AB10F8F-4576-481B-9270-5DCD25110DBB \\ ${ }^{3}$ urn:1sid:zoobank.org:author:925F2B42-7326-4461-B2A6-83CB83ECCC63 \\ ${ }^{4}$ urn:lsid:zoobank.org:author:81481AFA-C8EE-4E90-A954-FD0E7987621E \\ ${ }^{5}$ urn:lsid:zoobank.org:author:44C2A45A-B16C-434F-8F22-FC9C0FCA2551 \\ ${ }^{6}$ urn:lsid:zoobank.org:author:3C9DB6F9-2034-418F-876C-49359D07D29F
}

\begin{abstract}
The Changhsingian (Late Permian) Hambast Formation of sections at Baghuk Mountain (Central Iran) has yielded diverse ammonoid assemblages composed of the genera Pseudogastrioceras, Shevyrevites, Arasella, Dzhulfites, Paratirolites, Clivotirolites gen. nov., Esfahanites gen. nov., Alibashites, Lutites gen. nov., Abichites and Stoyanowites. The succession of ammonoid species allows for a subdivision of the rock unit into biozones, which largely correlate with the occurrences in northwestern Iran. Three new genera, Clivotirolites Korn \& Hairapetian gen. nov., Esfahanites Korn \& Hairapetian gen. nov. and Lutites Korn \& Hairapetian gen. nov., as well as 19 new species are described: Shevyrevites corrugatus Korn \& Hairapetian sp. nov., Arasella falcata Korn \& Hairapetian sp. nov., Dzhulfites brevisellatus Korn \& Hairapetian sp. nov., Paratirolites rubens Korn \& Hairapetian sp. nov., Paratirolites lanceolobatus Korn \& Hairapetian sp. nov., Paratirolites robustus Korn \& Hairapetian sp. nov., Paratirolites baghukensis Korn \& Hairapetian sp. nov., Paratirolites aduncus Korn \& Hairapetian sp. nov., Clivotirolites decoratus Korn \& Hairapetian gen. et sp. nov., Clivotirolites petilus Korn \& Hairapetian gen. et sp. nov., Esfahanites armatus Korn \& Hairapetian gen. et sp. nov., Lutites paucis Korn \& Hairapetian gen. et sp. nov., Lutites lyriformis Korn \& Hairapetian gen. et sp. nov., Lutites
\end{abstract}


profundus Korn \& Hairapetian gen. et sp. nov., Lutites alius Korn \& Hairapetian gen. et sp. nov., Lutites plicatus Korn \& Hairapetian gen. et sp. nov., Abichites ovalis Korn \& Hairapetian sp. nov., Abichites infirmus Korn \& Hairapetian sp. nov. and Stoyanowites parallelus Korn \& Hairapetian sp. nov. The material described here is, together with the material from NW Iran, the most diverse assemblage known from the interval before the end-Permian mass extinction.

Keywords. Ammonoids, Late Permian, Central Iran, biostratigraphy, morphometrics.

Korn D., Hairapetian V., Ghaderi A., Leda L., Schobben M. \& Akbari A. 2021. The Changhsingian (Late Permian) ammonoids from Baghuk Mountain (Central Iran). European Journal of Taxonomy 776: 1-106.

https://doi.org/10.5852/ejt.2021.776.1559

\section{Introduction}

The evolution of the organisms at the transition from the Palaeozoic to the Mesozoic is currently one of the major study areas in the field of palaeontology. Intensive investigations, however, are often hampered by the low number of regions in which fossil-rich sedimentary successions are exposed, both in the marine and the terrestrial realm. Sections that represent the deeper shelf and contain ammonoid assemblages, for instance, are known from only few regions worldwide, such as the Transcaucasus/NW Iranian region (e.g., Stoyanow 1910; Shevyrev 1965, 1968; Stepanov et al. 1969; Teichert et al. 1973; Kotlyar et al. 1983; Zakharov 1992; Ghaderi et al. 2014; Korn et al. 2016, 2019; Korn \& Ghaderi 2019) and South China (e.g., Zhao et al. 1978; Zheng 1981; Liang 1983; Yang 1987; Yang \& Yang 1992). For this reason, any new occurrence of latest Permian ammonoids bears the potential for a significant contribution to the knowledge of this fossil group.

Late Permian ammonoids from the area of Abadeh in Central Iran were discovered only half a century ago by Taraz $(1969,1971,1973)$ who briefly mentioned this discovery in several short reports. Subsequently, these sections in the Hambast Range (Kuh-e-Hambast; Fig. 1) were intensely studied by the Iranian-Japanese Research Group (Taraz et al. 1981) where a total of 50 (but almost half of them in open nomenclature) Wuchiapingian and Changhsingian ammonoid species were listed in a stratigraphic
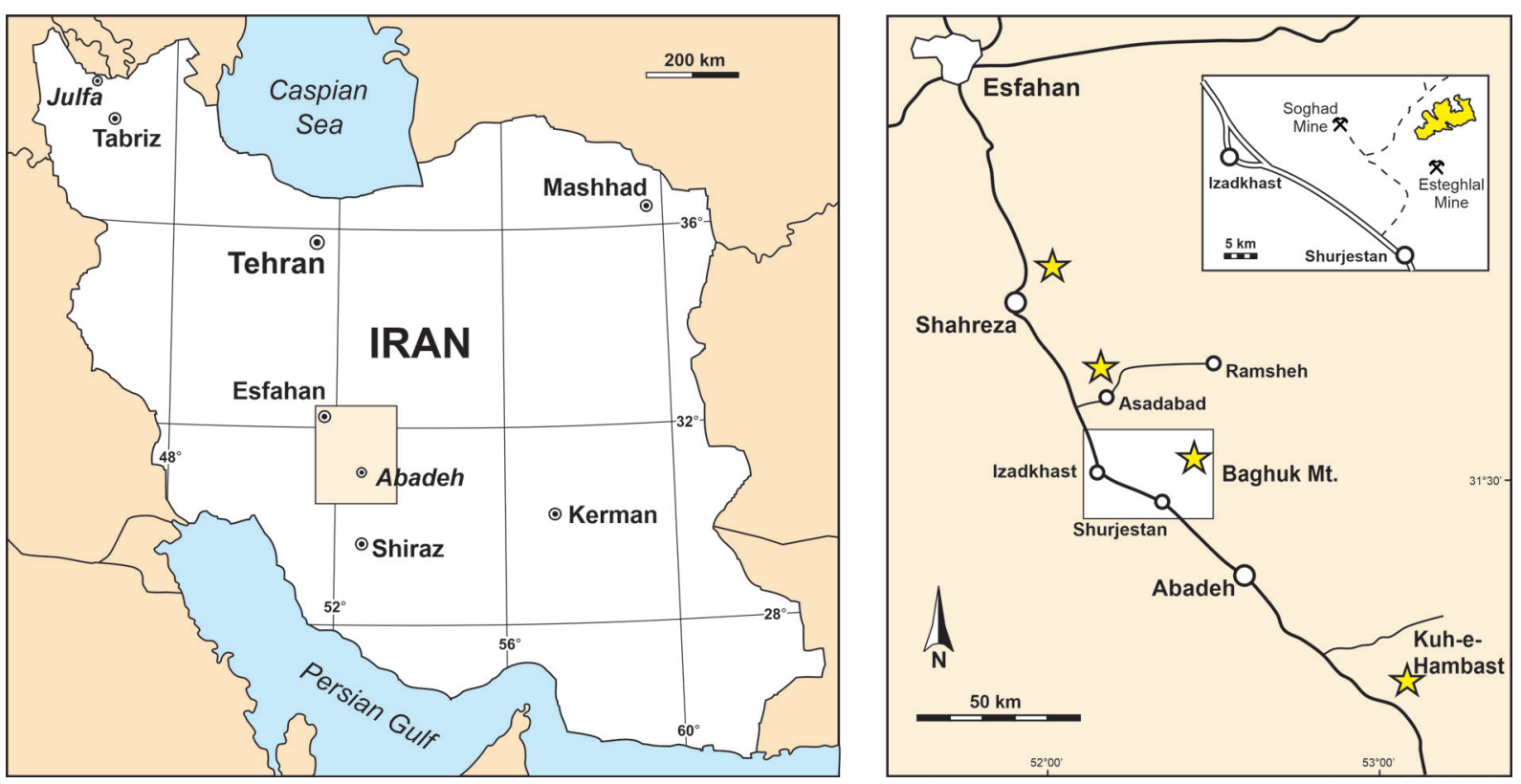

Fig. 1. Geographic position of Permian-Triassic boundary sections at Baghuk Mountain. 
chart. Descriptions of the Permian and the less species-rich Triassic assemblages were provided in the monographs by Bando $(1979,1981)$. In the first article, more than twenty ammonoid species, some in open nomenclature, were assigned to the Changhsingian.

The range charts of the ammonoids from the Hambast Range provided by Bando (1979) and Taraz et al. (1981) showed a mixture of Wuchiapingian and Changhsingian ammonoids, which putatively co-occur in some of the horizons. Araxoceras Ruzhencev, 1959, a characteristic early Wuchiapingian ammonoid genus, for instance, was reported to co-occur with the characteristic Changhsingian genera Shevyrevites Teichert \& Kummel, 1973 and Paratirolites Stoyanow, 1910. Problems of this kind in the stratigraphic succession of genera and species have not been discussed since. However, Zakharov et al. (2010) revised some Wuchiapingian ammonoids from the Hambast range and did not report such a co-occurrence.

The discovery of an ammonoid-bearing succession of Late Permian age at Baghuk Mountain allows for a study of the stratigraphic range of a number of ammonoid species in great detail. The outcrops enabled us to collect a large number of more than 570 determinable ammonoid specimens, of which 220 were collected in situ with precise assignment to the respective horizon. In the following, we present the first monographic description of the Changsingian species of these assemblages, which range among the most diverse in a global scale.

\section{Material and methods}

\section{Investigated outcrops}

Permian-Triassic strata are exposed in a number of outcrops at Baghuk Mountain (Fig. 1), a locality in Central Iran between the cities of Shahreza and Abadeh, that had a palaeogeographic position in the Palaeotethys near the equator (e.g., Stampfli \& Borel 2002) (Fig. 2). We investigated a total of eight parallel sections, all of which are very similar in their lithological succession (four of them illustrated in Fig. 3).

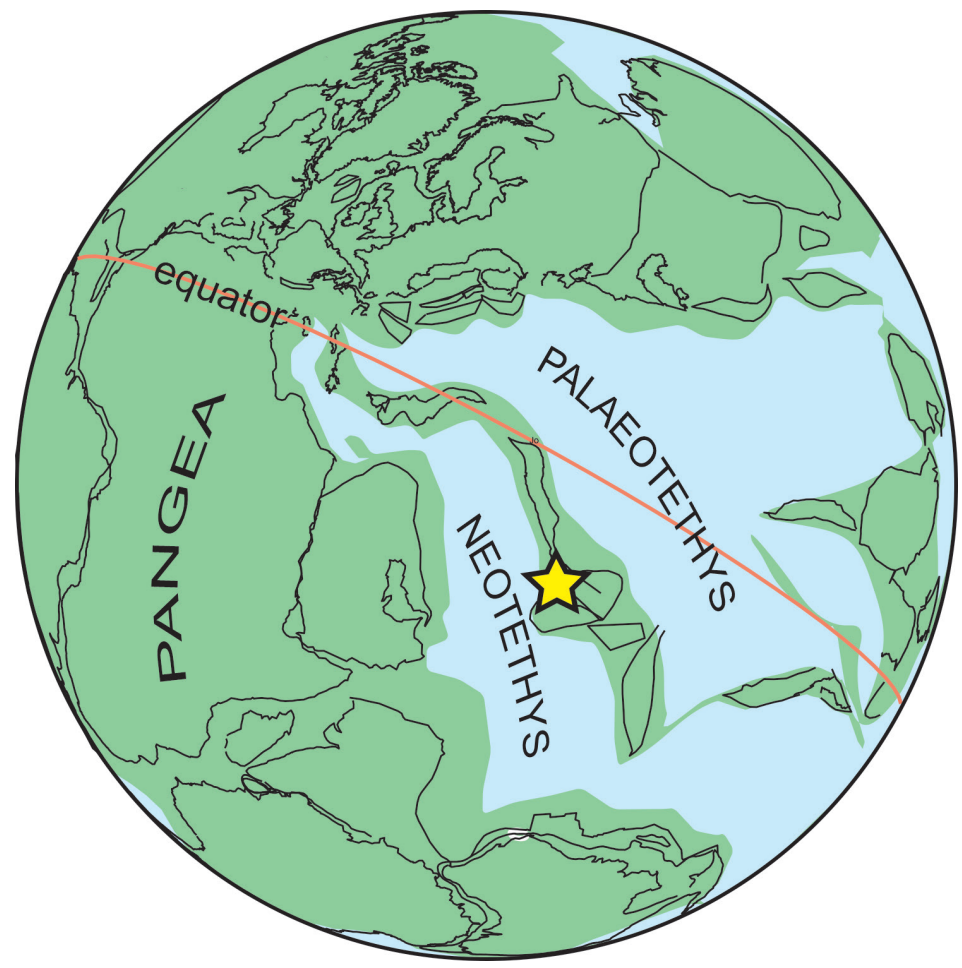

Fig. 2. Palaeogeographic position of the Baghuk Mountain area (after Stampfli \& Borel 2002). 
The Changhsingian stage is, in all sections of the area between Shahreza and Abadeh, composed of two major lithological units, (1) the upper part of the Hambast Formation (Taraz et al. 1981) and (2) the 'Boundary Clay', which was named Baghuk Member in the Central Iranian sections (Korn et al. 2021) and Aras Member in the sections of the Julfa region (Ghaderi et al. 2014).

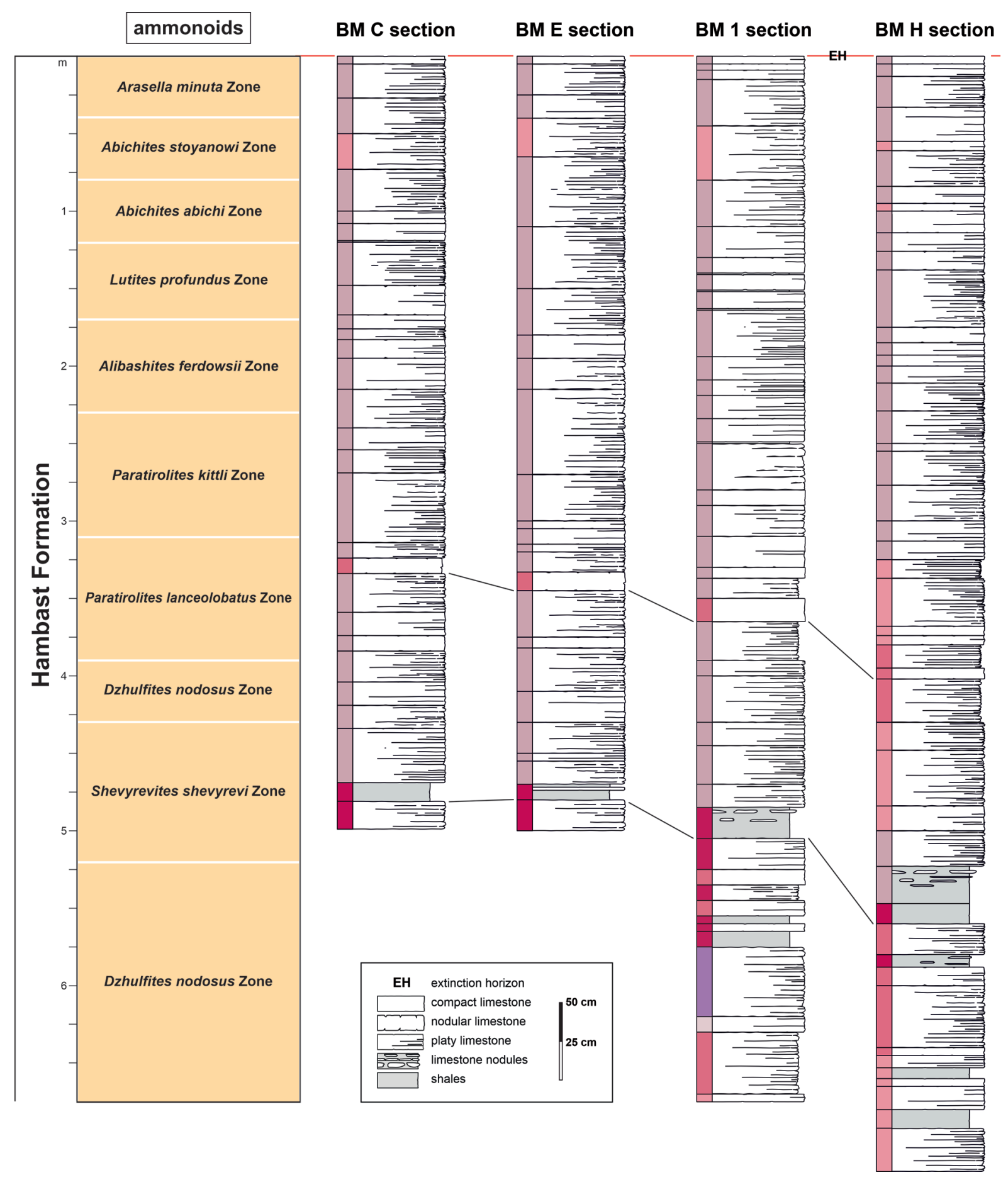

Fig. 3. Four selected columnar sections of the upper part of the Hambast Formation (Paratirolites Limestone equivalent) at Baghuk Mountain with their ammonoid zonation. 
(1) The upper part of the Hambast Formation has a thickness of about $17 \mathrm{~m}$, of which ca $8 \mathrm{~m}$ belong in the Wuchiapingian and $9 \mathrm{~m}$ in the Changhsingian (based on the discovery of a specimen of Vedioceras Ruzhencev, 1962 about 9.50 metres below the extinction horizon). Of these, the upper four metres can be correlated with the Paratirolites Limestone of the Julfa region. The unit ends with the end-Permian extinction event at the base of the Baghuk Member ('Boundary Clay'). The upper part of the Hambast Formation is nearly monotonic in its lithology, being composed of micritic nodular limestone forming beds of less than $10 \mathrm{~cm}$ thickness (Leda et al. 2014; Korn et al. 2021; Heuer et al. in press). Thin marly shale units of up to $40 \mathrm{~cm}$ thickness are intercalated and can be used as local index horizons. The most conspicuous of these is the purple shale unit within the range of the ammonoid species Shevyrevites shevyrevi; it has, in the parallel sections, a position between 4.70 and $5.50 \mathrm{~m}$ below the extinction horizon. A second very conspicuous local index horizon is a reddish-brown marly and compact limestone bed of 7 to $15 \mathrm{~cm}$ thickness in a position between 3.30 and $3.90 \mathrm{~m}$ below the extinction horizon.

(2) The interval described as the Baghuk Member ('Boundary Clay') is much more variable in thickness, composition and lithological succession. The unit begins with a shale unit of 50 to $100 \mathrm{~cm}$ thickness, but in section $\mathrm{C}$, a grey nodular limestone of $8 \mathrm{~cm}$ thickness is present close to the base. It yielded only poorly preserved ammonoids (Korn et al. 2021). At some places, the so-called 'calcite fans' (Taraz et al. 1981), recently interpreted as digitate stromatilites (Baud et al. 2021) occur in the upper part of this unit.

We sampled the following sections for ammonoids at Baghuk Mountain (for a detailed description of the sections, see Korn et al. 2021):

Baghuk Mountain A section $\left(31.56354^{\circ} \mathrm{N}, 52.43763^{\circ} \mathrm{E}\right)$ : it is the south-westernmost of the sections and exposes, in moderate outcrop conditions, the Hambast Formation and the early Triassic strata. Only a few ammonoids have been collected.

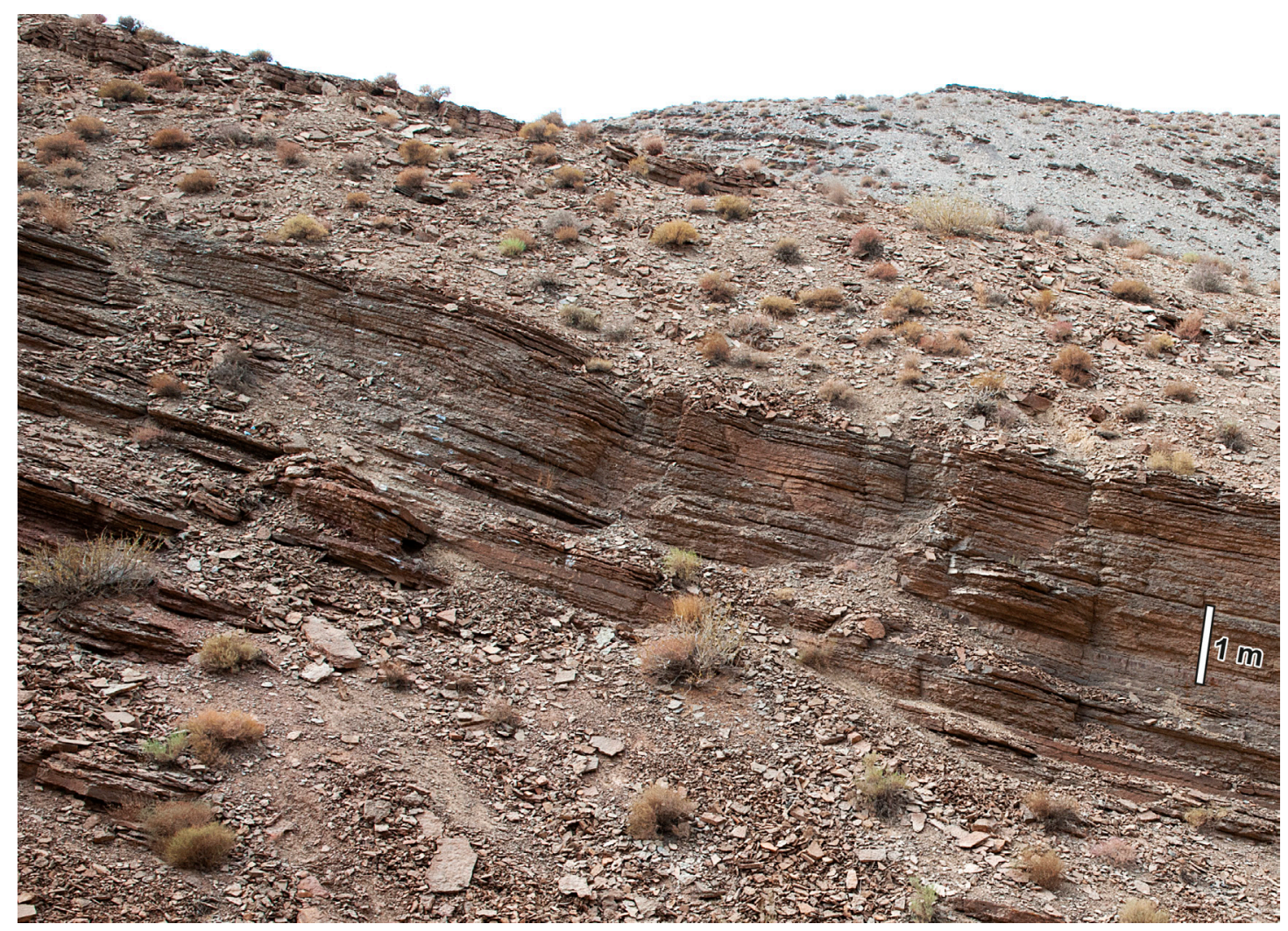

Fig. 4. The upper portion of the Hambast Formation (Paratirolites Limestone equivalent) in Baghuk Mountain 1 section. 
Baghuk Mountain 1 section $\left(31.56745^{\circ} \mathrm{N}, 52.44357^{\circ}\right.$ E; Fig. 5): it is the north-easternmost of the sections. The top five metres of the Hambast Formation are excellently exposed in a vertical gorge outcrop. The outcrop yielded numerous ammonoids with precise stratigraphic position (Figs 4-5).

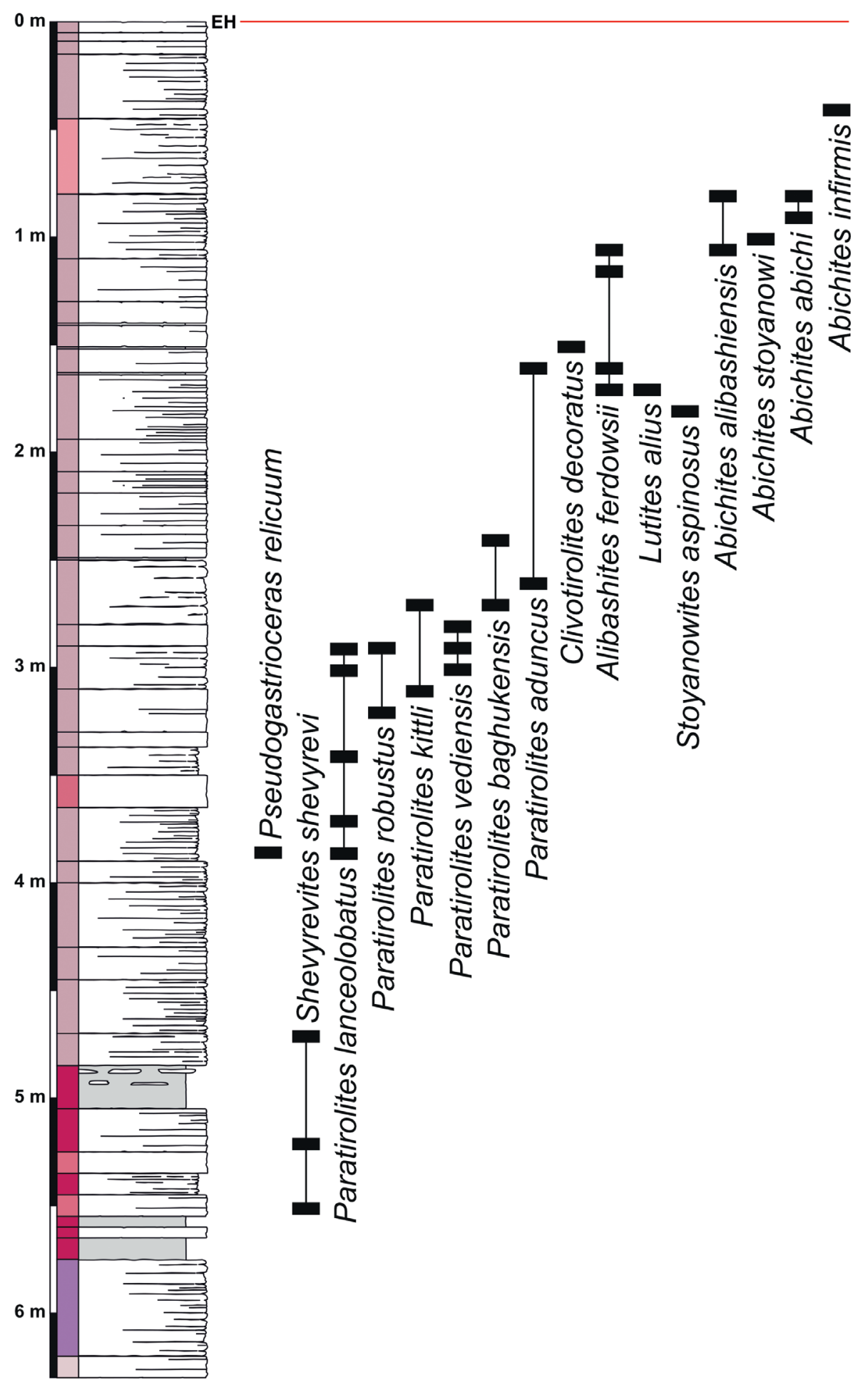

Fig. 5. The stratigraphic occurrence of the ammonoid species in the upper part of the Hambast Formation at Baghuk Mountain 1 section. $\mathrm{EH}=$ extinction horizon. 


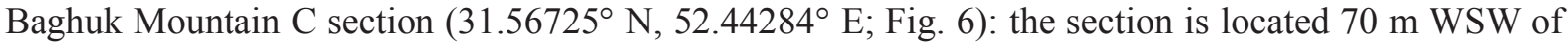
Baghuk Mountain 1 section in the next small gorge. The topmost four metres of the Hambast formation are exposed in a vertical gorge outcrop, followed by well-exposed Baghuk Member ('Boundary Clay') and the Claraia Beds, which belong to the earliest Triassic.

Baghuk Mountain E section $\left(31.56642^{\circ} \mathrm{N}, 52.44284^{\circ} \mathrm{E}\right.$; Fig. 7): the section is located $90 \mathrm{~m}$ south of the $\mathrm{C}$ section on the eastern side of the same gorge.

Baghuk Mountain G section (31.56681 ${ }^{\circ} \mathrm{N}, 52.44305^{\circ} \mathrm{E}$; Fig. 8): the section is located $50 \mathrm{~m}$ southsoutheast of the $\mathrm{C}$ section on the eastern side of the same gorge.

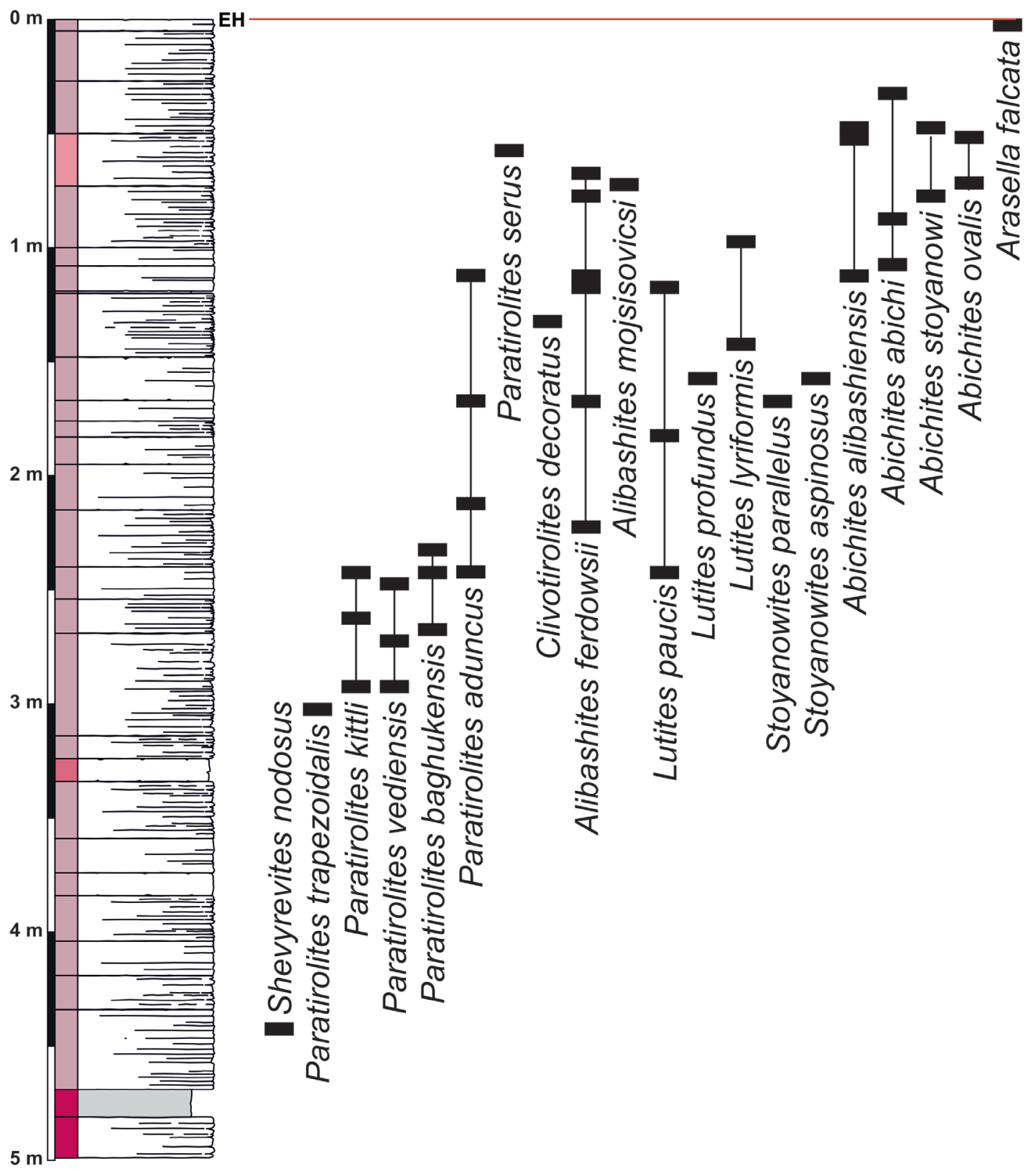

Fig. 6. The stratigraphic occurrence of the ammonoid species in the upper part of the Hambast Formation at Baghuk Mountain $\mathrm{C}$ section. $\mathrm{EH}=$ extinction horizon. 
Baghuk Mountain H section (31.56701 ${ }^{\circ} \mathrm{N}, 52.44350^{\circ}$ E; Fig. 9): the section is located $50 \mathrm{~m}$ south of Baghuk Mountain 1 section along the strike in the same gorge.

Baghuk Mountain F section $\left(31.56663^{\circ} \mathrm{N}, 52.44328^{\circ} \mathrm{E}\right)$ : the section is located $50 \mathrm{~m} \mathrm{SSW}$ of Baghuk Mountain $\mathrm{H}$ section along the strike in the same gorge. It is composed of several small fossiliferous outcrops.

Baghuk Mountain B section $\left(31.56425^{\circ} \mathrm{N}, 52.44159^{\circ} \mathrm{E}\right): 350 \mathrm{~m}$ south-southwest of the Baghuk Mountain C section.

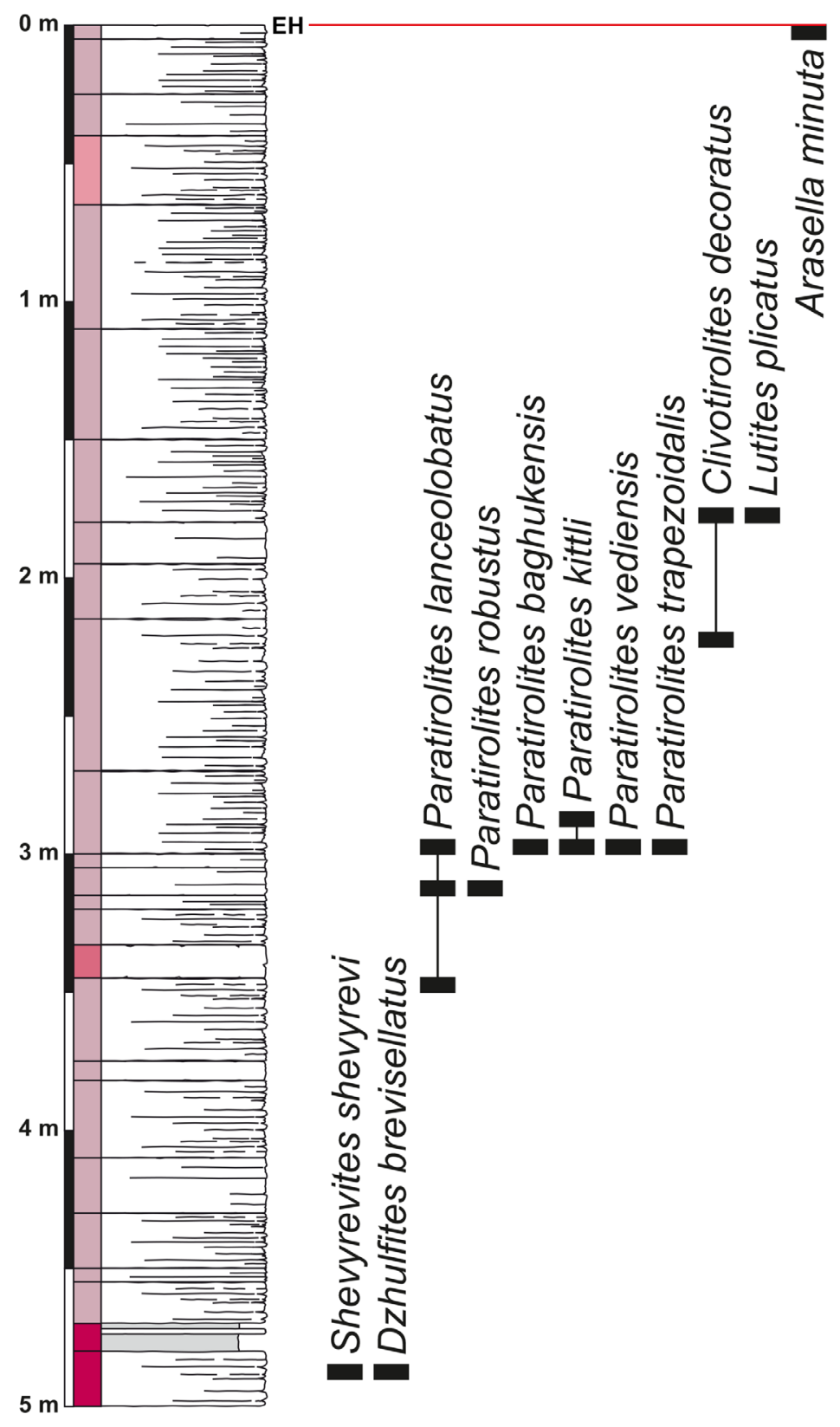

Fig. 7. The stratigraphic occurrence of the ammonoid species in the upper part of the Hambast Formation at Baghuk Mountain E section. EH=extinction horizon. 


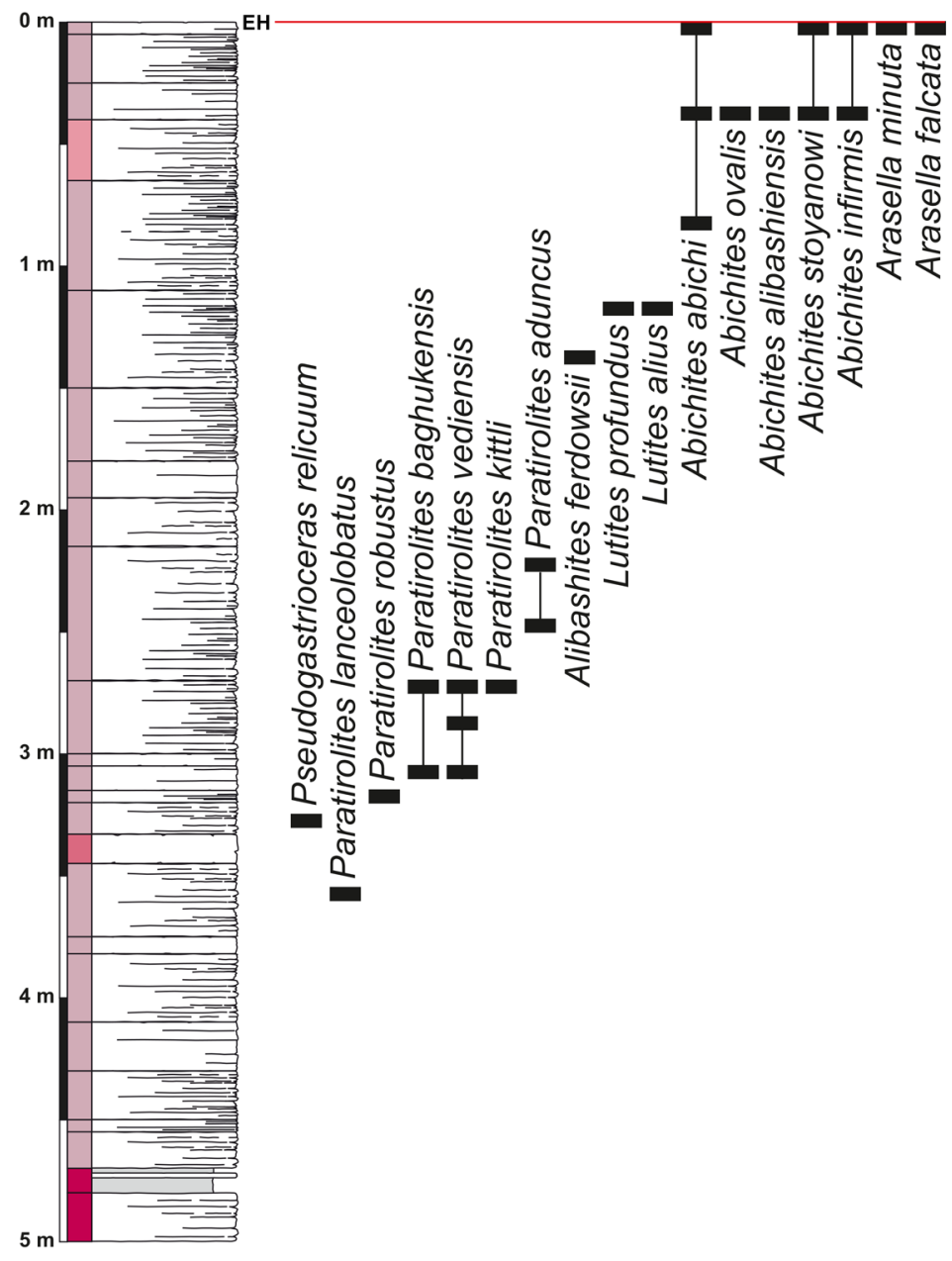

Fig. 8. The stratigraphic occurrence of the ammonoid species in the upper part of the Hambast Formation at Baghuk Mountain $\mathrm{G}$ section. $\mathrm{EH}=$ extinction horizon.

\section{Biostratigraphy of the Late Permian ammonoids from Central Iran}

\section{Hambast Range}

The Late Permian ammonoid succession in the Hambast range was outlined in two monographs by Bando (1979) and Taraz et al. (1981). While in the first of these the ammonoid material was described, a range chart was added to a detailed lithological description of the sections in the second.

Bando (1979) subdivided the Late Permian Hambast Formation in two units; he attributed the stratigraphically lower Unit 6 (dark grey limestone and marl) to the "Dzhulfian" (= Wuchiapingian) Araxoceras rotoides Zone with the Araxoceras rotoides and the Vedioceras nakamurai subzones and the stratigraphically upper Unit 7 (red to purple marly limestone) to the "Dorashamian" (= Changhsingian) Shevyrevites shevyrevi Zone with the Shevyrevites shevyrevi and the Paratirolites kittli subzones. According to Bando (1979), the latter subzone has a thickness of 12 metres and contains, besides several species of Paratirolites Stoyanow, 1910, also Araxoceras Ruzhencev, 1959, Julfotoceras Bando, 1973, Dzhulfoceras Ruzhencev, 1962, Shevyrevites Teichert \& Kummel, 1973 and Iranites Teichert \& Kummel, 1973 - genera which are not known to co-occur with Paratirolites at any other place. 


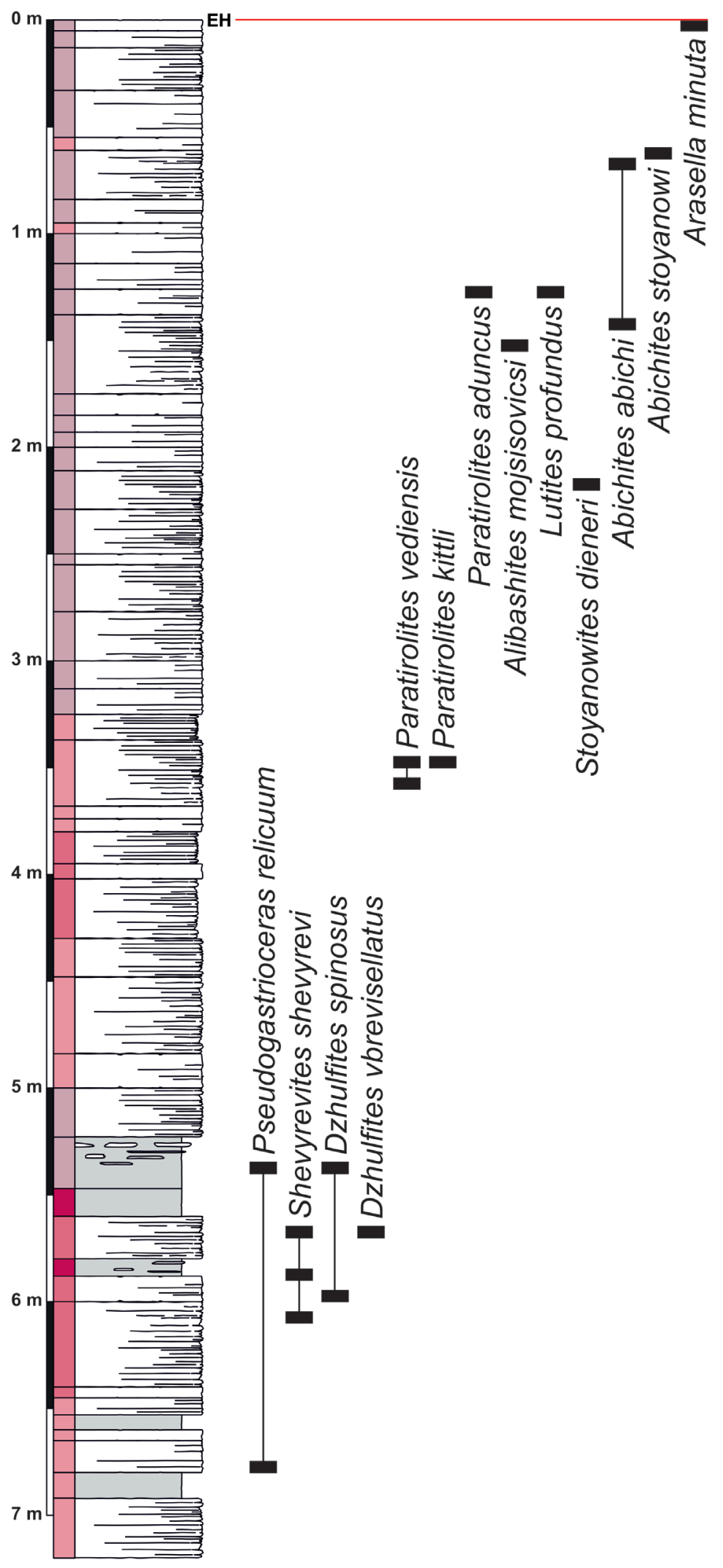

Fig. 9. The stratigraphic occurrence of the ammonoid species in the upper part of the Hambast Formation at Baghuk Mountain $\mathrm{H}$ section. $\mathrm{EH}=$ extinction horizon. 
The conspicuous discrepancy in the putative ammonoid succession between the Hambast Range and other regions such as NW Iran (e.g., Ghaderi et al. 2014; Korn et al. 2016, 2019; Kiessling et al. 2018) and Baghuk Mountain (this paper) is surprising. According to current knowledge, all Late Permian sections between Shahreza and the Hambast Range are very similar in their lithology; significant changes in thickness and lithology are not known. Kozur (2005), for instance, showed that the sections of the Hambast Range do not differ, in their thickness of the latest Permian portion, from the sections in NW Iran. There is thus no reason to assume large differences in the thickness of subunits of the Hambast Formation and their ammonoid succession between the neighbouring sections in the Hambast Range and Baghuk Mountain. It is more likely that mixing of material described by Bando (1979) resulted in the discrepancies.

\section{Baghuk Mountain}

All of the sections at Baghuk Mountain show a very similar lithological succession (Fig. 3), and hence correlation between them can easily be done with laterally continuous beds. The interval studied here comprises of the upper part of the Hambast Formation, of which the top four metres are an equivalent of the Paratirolites Limestone of Transcaucasia and NW Iran (e.g., Ghaderi et al. 2014; Leda et al. 2014; Korn et al. 2016; Kiessling et al. 2018). In contrast to the NW Iranian sections, the Late Permian succession at Baghuk Mountain is almost entirely composed of carbonates; a shale equivalent of the Zal Member is missing in Central Iran.

We recorded a total of 37 Changhsingian ammonoid species from Baghuk Mountain; material of all except for four were collected in situ with distinct stratigraphic position (Figs 5-9) and the remaining are from float collections.

Of the classical succession of ammonoids known from Transcaucasia (Shevyrev 1965, 1968; Teichert et al. 1973) with the genera Phisonites, Iranites, Dzhulfites, Shevyrevites and Paratirolites, only the latter three have been recorded at Baghuk Mountain. However, when compared with the sections near Julfa, several other differences occur between the two sites (Fig. 10):

\begin{tabular}{|c|c|c|}
\hline Julfa & Baghuk Mountain & Conodont zonation \\
\hline \multirow{2}{*}{ Arasella minuta Zone } & \multirow{2}{*}{ Arasella minuta Zone } & Clarkina hauschkei Zone \\
\hline & & Clarkina abadehensis Zone \\
\hline Abichites stoyanowi Zone & Abichites stoyanowi Zone & \multirow{4}{*}{ Clarkina yini Zone } \\
\hline Abichites abichi Zone & Abichites abichi Zone & \\
\hline Alibashites mojsisovicsi Zone & Alibashites profundus Zone & \\
\hline Stoyanowites dieneri Zone & Alibashites ferdowsii Zone & \\
\hline Paratirolites kittli Zono & Paratirolites kittli Zone & \multirow[b]{2}{*}{ Clarkina bachmanni Zone } \\
\hline Paratirolites trapezoidalis Zone & Paratirolites lanceolobatus Zone & \\
\hline Dzhulfites zalensis Zone & Shevyrevites nodosus Zone & \multirow{2}{*}{ Clarkina changxingensis Zone } \\
\hline Shevyrevites shevyrevi Zone & Shevyrevites shevyrevi Zone & \\
\hline Dzhufites spinosus Zone & Dzhufites spinosus Zone & Clarkina subcarinata Zone \\
\hline
\end{tabular}

Fig. 10. Correlation of the ammonoid zonations of the Julfa region in NW Iran (after Korn et al. 2016) and Baghuk Mountain with the conodont stratigraphy (after Farshid et al. 2016). 
- An interval between Shevyrevites shevyrevi and first Paratirolites, characterised by species of Dzhulfites in the Julfa region, has not been found at Baghuk Mountain. At Baghuk Mountain, Shevyrevites nodosus serves as an index fossil for this interval.

- The earliest species of Paratirolites at Baghuk Mountain is P. lanceolobatus sp. nov. (Fig. 11); P. trapezoidalis, the index in the Julfa sections, is rare at Baghuk Mountain and thus less suitable.

- The first occurrences of ammonoid species near Julfa and Baghuk Mountain differs to some degree. For instance, the zones of Stoyanowites dieneri and Alibashites mojsisovicsi of the Julfa sections

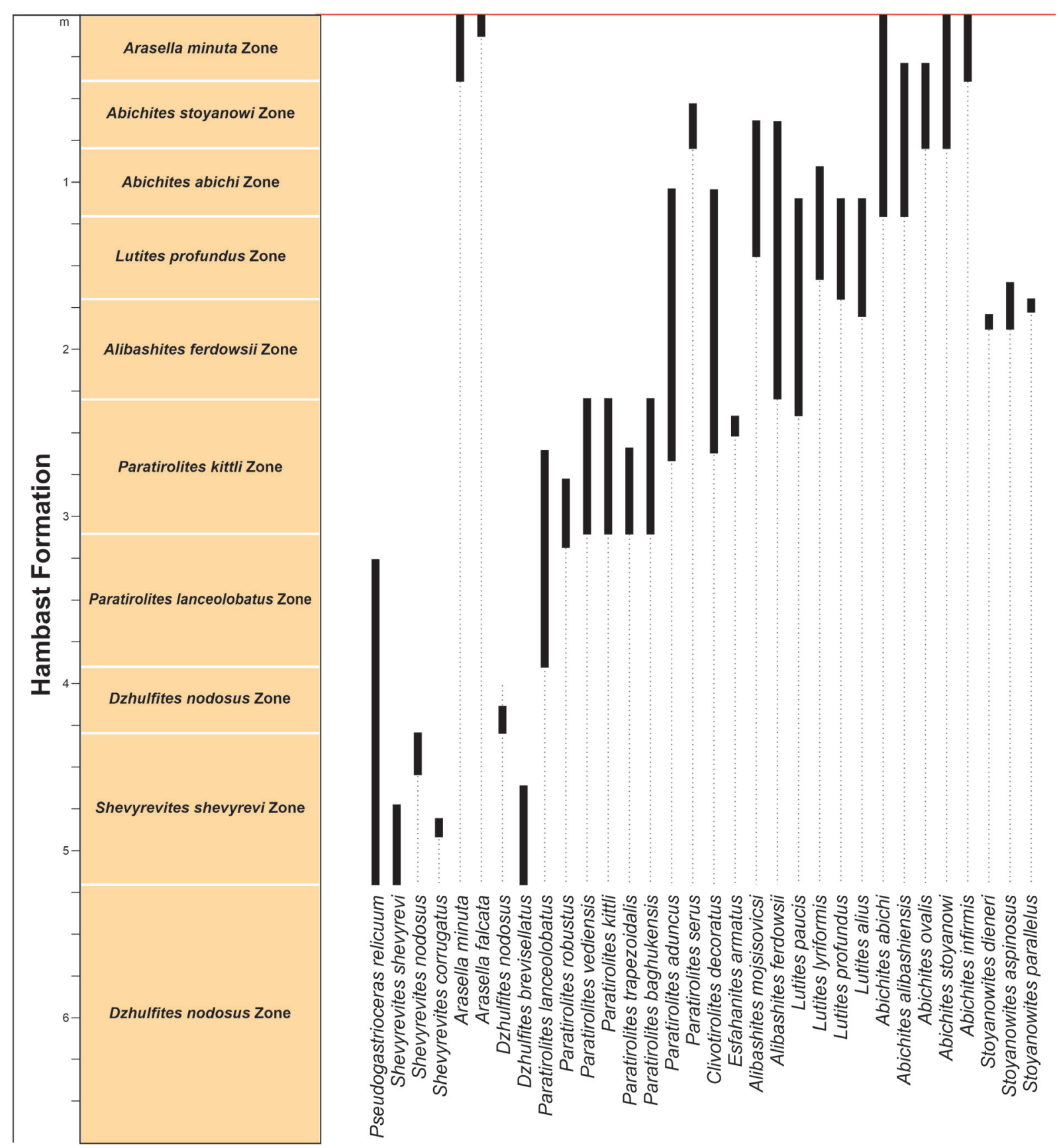

Fig. 11. Summary of the stratigraphic occurrence of the ammonoid species at Baghuk Mountain. 
have to be replaced, in the Baghuk Mountain sections, by the zones of Alibashites ferdowsii and Lutites profundus gen. et sp. nov.

- The genera Clivotirolites gen. nov. and Esfahanites gen. nov. are not known from Julfa.

- The genus Alibashites is more common and diverse at Baghuk Mountain.

Similarities are as follows:

- The general stratigraphic position of the genera Paratirolites, Alibashites, Abichites and Stoyanowites at Baghuk Mountain agrees with Julfa.

- At the top of the Paratirolites Limestone, in both regions occur very small ammonoids of the genus Arasella with simple suture line (Fig. 12).

In the systematic descriptions of the ammonoids, stratigraphic positions of the records are given in metres below the extinction horizon (the plane that separates the nodular limestone from the Baghuk Member). Baghuk Mountain C section was used as the reference; the other sections were correlated by graphic correlation using the two index horizons (red shale with Shevyrevites and dark-red limestone marker bed) as references.

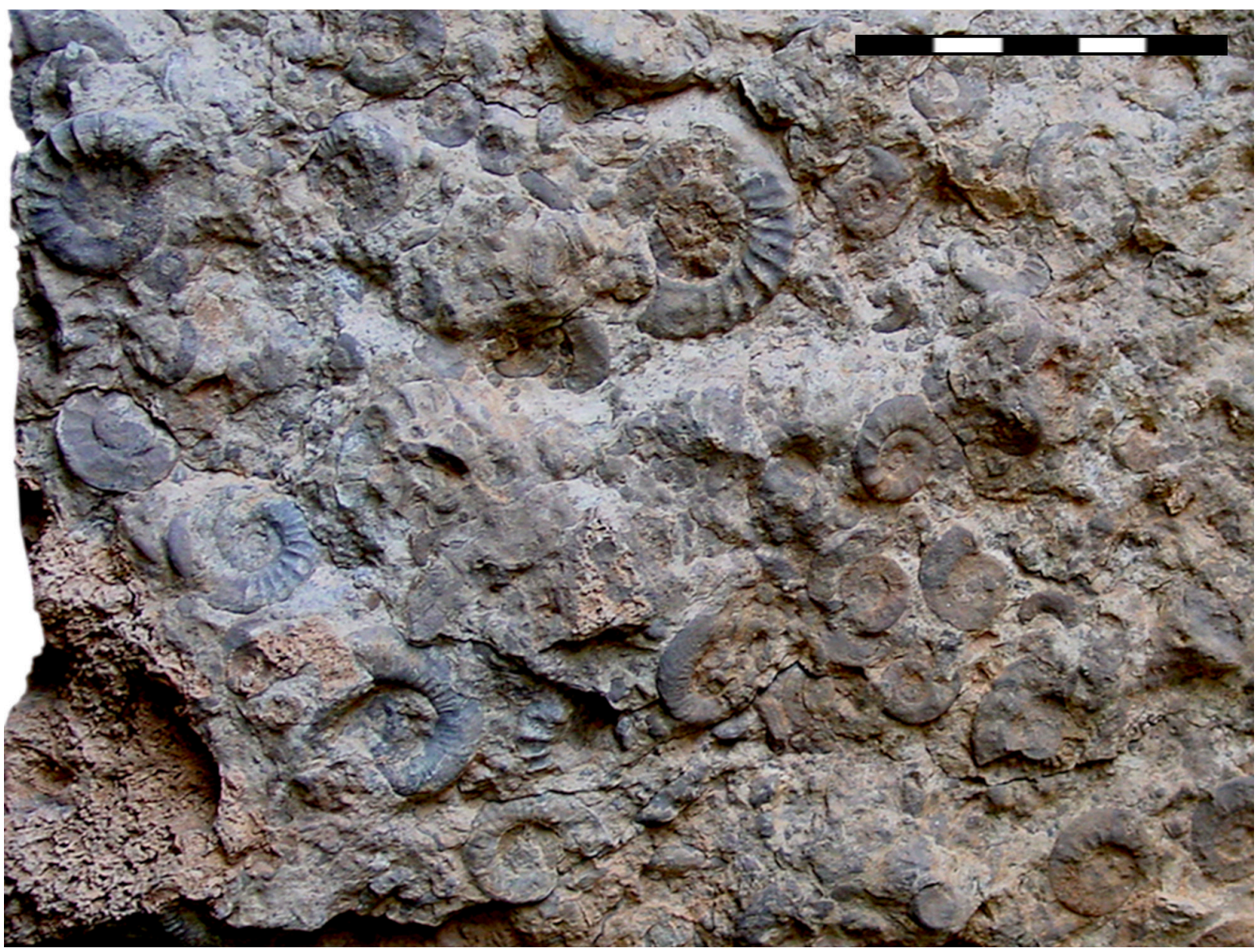

Fig. 12. Mass occurrence of small ammonoids of the genus Arasella Korn in Ghaderi et al., 2014 on the bedding surface at the base of the topmost $5 \mathrm{~cm}$ limestone bed, Baghuk Mountain section H. Scale bar units $=10 \mathrm{~mm}$. 


\section{Specimens studied}

We investigated a total of more than 700 specimens from the upper seven metres of the Hambast Formation, of which 571 specimens were identified to the species level. The following species are represented:

Pseudogastrioceras relicuum Korn \& Ghaderi in Korn et al., 2016 - 5 specimens

Shevyrevites shevyrevi Teichert \& Kummel in Teichert et al., $1973-173$ specimens

Shevyrevites nodosus (Shevyrev, 1965) - 5 specimens

Shevyrevites corrugatus Korn \& Hairapetian sp. nov. - 2 specimens

Arasella minuta (Zakharov in Kotlyar et al., 1983) - 13 specimens

Arasella falcata Korn \& Hairapetian sp. nov. - 5 specimens

Dzhulfites spinosus Shevyrev, 1965 - 8 specimens

Dzhulfites brevisellatus Korn \& Hairapetian sp. nov. -3 specimens

Paratirolites rubens Korn \& Hairapetian sp. nov. - 2 specimens

Paratirolites lanceolobatus Korn \& Hairapetian sp. nov. - 25 specimens

Paratirolites robustus Korn \& Hairapetian sp. nov. -9 specimens

Paratirolites vediensis Shevyrev, 1965 - 28 specimens

Paratirolites kittli Stoyanow, 1910 - 29 specimens

Paratirolites coronatus Korn \& Ghaderi in Korn et al., 2016 - 1 specimen

Paratirolites trapezoidalis Shevyrev, 1965 - 6 specimens

Paratirolites baghukensis Korn \& Hairapetian sp. nov. - 31 specimens

Paratirolites aduncus Korn \& Hairapetian sp. nov. - 51 specimens

Paratirolites quadratus Korn \& Ghaderi in Korn et al., 2016 - 3 specimens

Paratirolites serus Korn \& Ghaderi in Korn et al., 2016 - 4 specimens

Clivotirolites decoratus Korn \& Hairapetian gen. et sp. nov. - 24 specimens

Clivotirolites petilus Korn \& Hairapetian gen. et sp. nov. - 1 specimen

Esfahanites armatus Korn \& Hairapetian gen. et sp. nov. -6 specimens

Alibashites mojsisovicsi (Stoyanow, 1910) - 4 specimens

Alibashites ferdowsii Korn \& Ghaderi in Korn et al., 2016 - 18 specimens

Lutites paucis Korn \& Hairapetian gen. et sp. nov. -3 specimens

Lutites lyriformis Korn \& Hairapetian gen. et sp. nov. -8 specimens

Lutites profundus Korn \& Hairapetian gen. et sp. nov. -7 specimens

Lutites alius Korn \& Hairapetian gen. et sp. nov. -9 specimens

Lutites plicatus Korn \& Hairapetian gen. et sp. nov. -1 specimen

Abichites abichi Shevyrev, 1965 - 22 specimens

Abichites alibashiensis Korn \& Ghaderi in Korn et al., 2016 - 18 specimens

Abichites ovalis Korn \& Hairapetian sp. nov. - 13 specimens

Abichites stoyanowi (Kiparisova in Voinova et al., 1947) - 10 specimens

Abichites infirmis Korn \& Hairapetian sp. nov. -6 specimens

Stoyanowites dieneri (Stoyanow, 1910) - 8 specimens

Stoyanowites aspinsus Korn \& Ghaderi in Korn et al., 2016 - 5 specimens

Stoyanowites parallelus Korn \& Hairapetian sp. nov. - 4 specimens

All specimens were embedded in thin bedded flaser limestone and display a specific mode of preservation (Leda et al. 2014). The upper surface of the originally aragonitic ammonoid conchs is truncated by dissolution, whereas the lower face is usually much better preserved (Fig. 13). Dissolution of the shell material probably resulted from selective, partial dissolution of aragonite. This mode of preservation is the reason for the incomplete specimens, which are usually preserved only on one side. For this reason, the specimens are illustrated here by photographs in lateral view, while dorsal views are shown as reconstructions. 
Descriptions of the ammonoids largely follow the scheme and terminology proposed by Korn (2010) and Klug et al. (2015) for Palaeozoic ammonoids (Fig. 14). For the shape of the cross sections, an additional explanation of terminology was given by Korn et al. (2016), distinguishing between trapezoidal, quadrate, subtrapezoidal, circular and oval (Fig. 15). The terminology of the suture line follows Korn et al. (2003), meaning that a difference between an A-mode (goniatitic) and U-mode (prolecanitic and thus also ceratitic) sutural ontogeny, as proposed by Schindewolf (1929), is not accepted. The sutural elements described here are therefore external (E), adventive (A), lateral (L), umbilical (U) and internal (I) lobes (Fig. 15). In the following, the stratigraphic position of individual specimens and the range of species are explained in metres below the extinction horizon (top surface of the Hambast Formation).

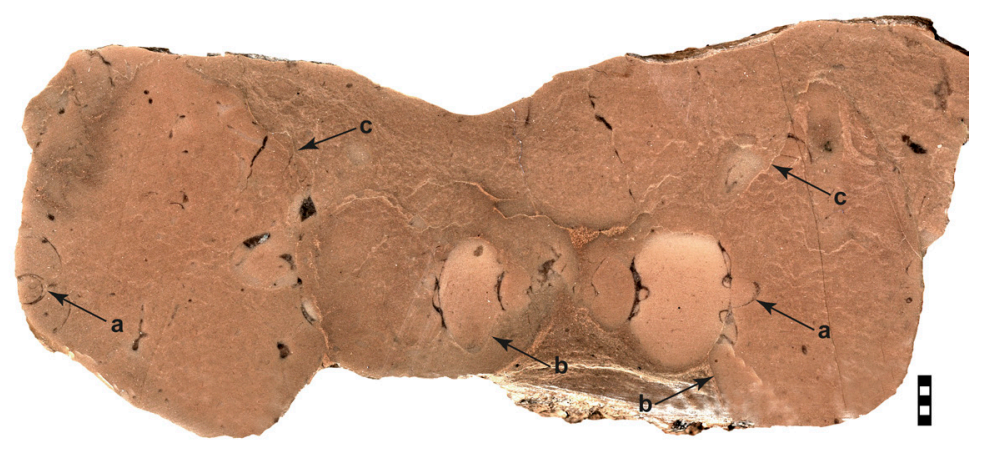

Fig. 13. Cross section of a specimen of Paratirolites sp. from Baghuk Mountain, MB.C.22215; note the different states of preservation of shell walls and septa: $a=$ recrystallized but rather well-preserved shell wall and septa preferably in the mid-dorsal portion of the ammonoid conch; $b=$ dissolved shell wall but sharp demarcation of the ammonoid's internal mould from the sediment at the lower side of the ammonoid conch; $\mathrm{c}=$ dissolved shell wall and nearly continuous transition from the ammonoid's internal mould towards the sediment on the upper side of the ammonoid conch (from Leda et al. 2014).

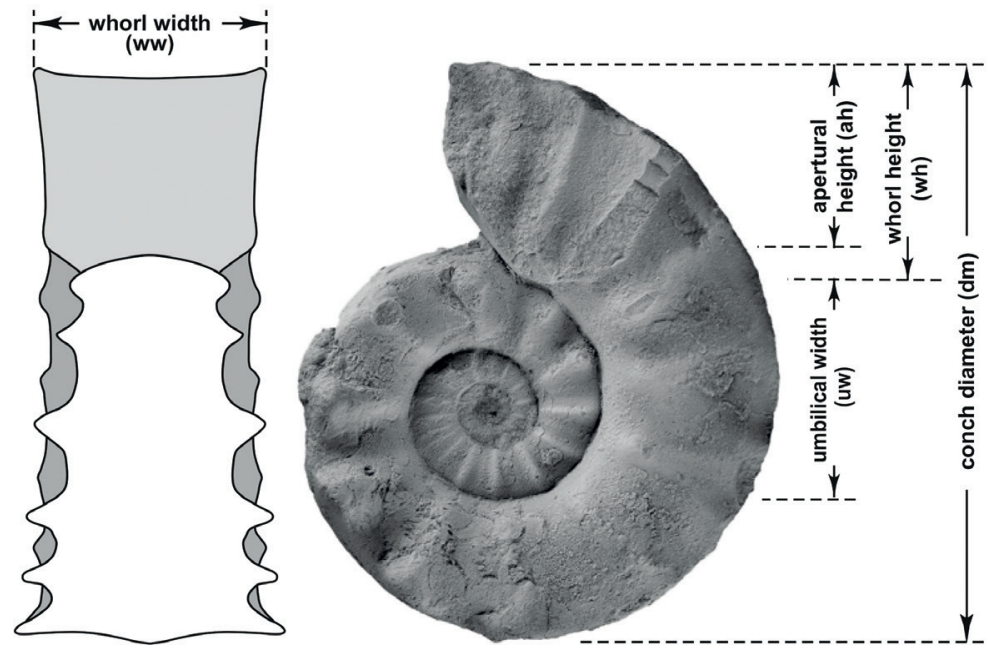

Fig. 14. Descriptive terms for the conch geometry of the ammonoids described here (from Korn et al. 2016). 

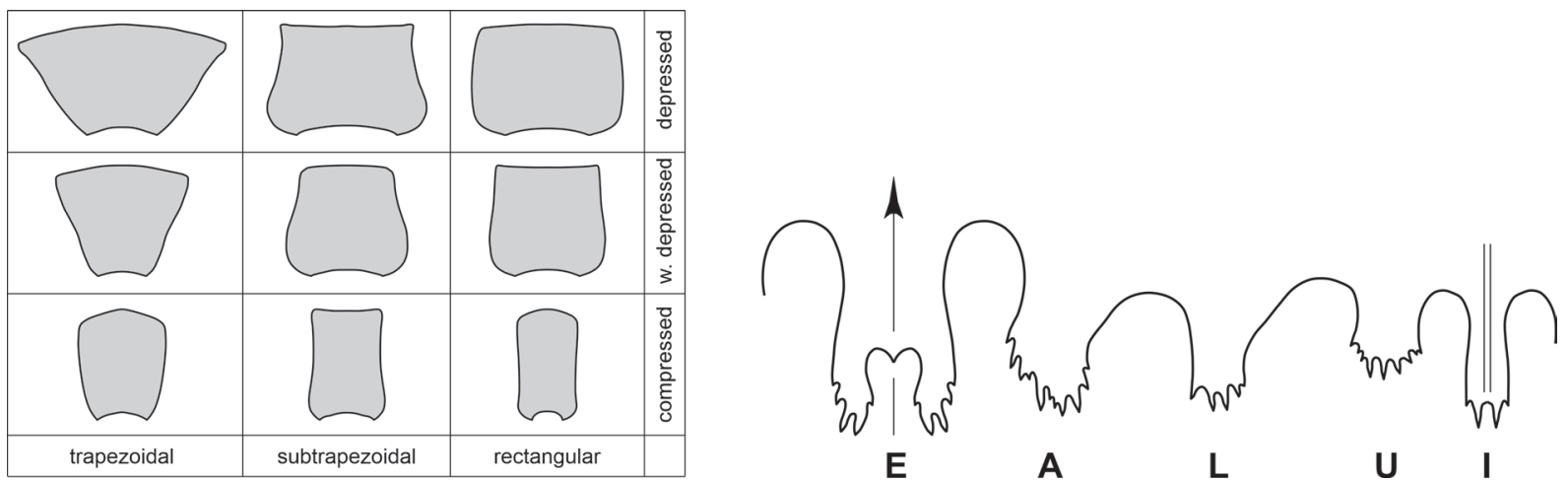

Fig. 15. Descriptive terms for the whorl profiles and suture lines (exemplified in Paratirolites kittli Stoyanow, 1910) of the paratirolitid ammonoids described here (from Korn et al. 2016).

\section{Abbreviations used in the species descriptions:}

$\begin{array}{ll}\text { ah } & =\text { apertural height } \\ \mathrm{dm} & =\text { conch diameter } \\ \mathrm{IZR} & =\text { imprint zone rate } \\ \mathrm{uw} & =\text { umbilical width } \\ \mathrm{WER} & =\text { whorl expansion rate } \\ \mathrm{wh} & =\text { whorl height } \\ \mathrm{ww} & =\text { whorl width }\end{array}$

\section{Abbreviations of the repositories:}

MB.C. = Cephalopod collection of the Museum für Naturkunde, Berlin

PIN = Palaeontological Institute of the Academy of Sciences, Moscow

$\mathrm{MCZ}=$ Museum of Comparative Zoology, Harvard

Results (Korn \& Hairapetian)

Order Goniatitida Hyatt, 1884

Suborder Goniatitina Hyatt, 1884

Superfamily Neoicocerataidea Hyatt, 1900

Family Paragastrioceratidae Ruzhencev, 1951

Subfamily Pseudogastrioceratinae Furnish, 1966

For the composition of the subfamily, see Korn \& Ghaderi in Korn et al. (2016).

Genus Pseudogastrioceras Spath, 1930

For the composition of the genus, see Korn \& Ghaderi in Korn et al. (2016).

Pseudogastrioceras relicuum Korn \& Ghaderi in Korn et al., 2016

Fig. 16; Table 1

Pseudogastrioceras relicuum Korn \& Ghaderi in Korn et al., 2016: 852, text-fig. 12. 
Table 1. Conch dimensions (partly estimated) and ratios of a specimen of Pseudogastrioceras relicuum Korn \& Ghaderi in Korn et al., 2016 from Baghuk Mountain.

\begin{tabular}{ccccccccccc}
\hline Specimen & dm & ww & wh & uw & ah & ww/dm & ww/wh & uw/dm & WER & IZR \\
\hline MB.C.29661 & 57.4 & - & 28.1 & 5.3 & 16.8 & - & - & 0.09 & 2.00 & 0.40 \\
& 41.5 & 18.5 & 21.3 & 3.1 & - & 0.45 & 0.87 & 0.07 & - & - \\
\hline
\end{tabular}

\section{Diagnosis}

Pseudogastrioceras with moderately large conch; diameter attaining $70 \mathrm{~mm}$. Conch shape thinly discoidal $(\mathrm{ww} / \mathrm{dm}=0.40-0.45)$, involute (uw/ $\mathrm{dm}=0.05-0.10)$ with converging flanks and broadly rounded venter. Ornament with about 15 faint spiral lines on the venter.

\section{Material examined}

\section{Holotype}

IRAN • East Azerbaijan, Ali Bashi N section; Paratirolites Limestone; illustrated by Korn \& Ghaderi in Korn et al. (2016: text-fig. 12); MB.C.25173.

\section{Additional material}

IRAN • 2 specimens; Esfahan Province, Baghuk Mountain 1 section; Hambast Formation; MB.C.29659 to MB.C.29660 - 1 specimen; Esfahan Province, Baghuk Mountain G section; Hambast Formation; MB.C.29661 - 2 specimens; Esfahan Province, Baghuk Mountain H section; Hambast Formation; MB.C.29662 to MB.C.29663.

\section{Description}

All specimens are rather poorly preserved, but MB.C.29661 is the best of them, though somewhat deformed (Fig. 16). It is a corroded specimen with a $56 \mathrm{~mm}$ conch diameter, which does not allow accurate measurements of the conch.

\section{Stratigraphic range}

Paratirolites Limestone; 6.80 to $3.30 \mathrm{~m}$ below the extinction horizon (Dzhulfites nodosus Zone to Paratirolites lanceolobatus Zone).

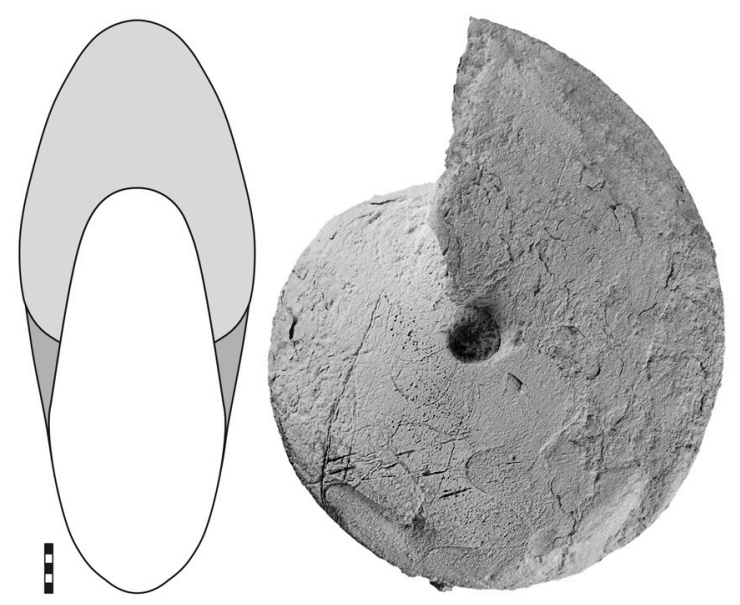

Fig. 16. Pseudogastrioceras relicuum Korn \& Ghaderi, 2016, lateral and reconstructed dorsal views of specimen MB.C.29661. Scale bar units $=1 \mathrm{~mm}$. 
Order Ceratitida Hyatt, 1884

Suborder Paraceltitina Shevyrev, 1968

Superfamily Xenodiscoidea Frech, 1902

Family Xenodiscidae Frech, 1902

\section{Diagnosis}

Representatives of the superfamily Xenodiscoidea with a small to moderately large conch, in which the ontogeny displays up to three stages, beginning with an unsculptured initial stage followed by a juvenile stage with transverse ribs, and an adult stage with a weakening of the sculpture. Suture line with unserrated or weakly serrated, short but rather wide external lobe; adventive, lateral and umbilical lobe often multidentate; some species with a simplified suture line without serrations.

\section{Included Permian genera}

Iranites Teichert \& Kummel, 1973; Laibinoceras Yang, 1987; Multisulcites Liang, 1983; Paraceltitoides Zheng \& Chen, 1979; Penglaites Yang, 1987; Phisonites Shevyrev, 1965; Shevyrevites Teichert \& Kummel in Teichert et al., 1973; Xenodiscus Waagen, 1879.

Genus Shevyrevites Teichert \& Kummel in Teichert et al., 1973

\section{Type species}

Shevyrevites shevyrevi Teichert \& Kummel in Teichert et al., 1973, by original designation.

\section{Diagnosis}

Representatives of the family Xenodiscidae with a moderately large to large conch; maximum adult diameter between 60 and $80 \mathrm{~mm}$. Subadult stage with a trapezoidal whorl profile, adult stage variable. Subadult stage with small to large conical ventrolateral nodes, adult stage with a weakening sculpture with predominant ribs. Suture line with external lobe that does not reach the depth of the adventive lobe; prongs of the external lobe simple or bifid.

\section{Included species}

Shevyrevites shevyrevi Teichert \& Kummel in Teichert et al., 1973; Bernhardites nodosus Shevyrev, 1965; Shevyrevites corrugatus Korn \& Hairapetian sp. nov.

\section{Remarks}

The species of Shevyrevites show a coarse ornament consisting of lateral ribs and sometimes also coarse conical nodes in the inner whorls, and are hereby clearly separated from the other genera of the family. Regarding the presence of ventrolateral nodes, there are some similarities to the genera of the family Dzhulfitidae, but these differ in the shape of the suture line: while the external lobe is wide in Shevyrevites, it is always narrow in the Dzhulfitidae.

Teichert \& Kummel (in Teichert et al. 1973) caused some nomenclatorial confusion with their opinion on the species of their new genus Shevyrevites. They made clear that "Celtites radiosus", the Triassic type species of Bernhardites Shevyrev, 1965, differs from the Late Permian forms and that for the latter, a new genus name (Shevyrevites) had to be introduced. At the same time, they treated the two species "Bernhardites radiosus (Frech in Noetling, 1905)" and "Bernhardites nodosus Shevyrev, 1965", both of which were separated by Shevyrev (1965), as synonyms; they described these under the new genus and species name Shevyrevites shevyrevi. This procedure is not accepTable because it suppresses the species name Shevyrevites nodosus, which in case of synonymy of the two species has priority over Shevyrevites shevyrevi. However, this problem is regarded here minor, as we accept both species as valid. 
Shevyrevites shevyrevi Teichert \& Kummel in Teichert et al., 1973

Fig. 17; Table 2

Shevyrevites shevyrevi Teichert \& Kummel in Teichert et al., 1973: 410, pl. 3 figs 1-3, 6.

Bernhardites radiosus - Shevyrev 1965: 171, pl. 21 fig. 7; 1968: 86, pl. 1 fig. 7, pl. 2 fig. 1.

Shevyrevites shevyrevi - Bando 1979: 133, pl. 5 figs 1, 5, pl. 8 figs 6-7. - Korn et al. 2019: 46, textfigs 11-12.

non Shevyrevites shevyrevi - Zhao et al. 1978: 107, pl. 11 figs 2-4, 6-7.

\section{Diagnosis}

Species of Shevyrevites with conch reaching $70 \mathrm{~mm}$ dm. Subadult stage with oval, compressed whorl profile (ww/wh $=0.70-0.90)$ and rounded venter; 30 coarse ribs per volution. Adult stage with rectangular and compressed whorl profile ( $\mathrm{ww} / \mathrm{wh}=0.70-0.80$ ), flattened flanks, flattened venter and subangular ventrolateral shoulder; coarse and sharp ribs on the flank, venter smooth. Prongs of external lobe usually bifid; altogether 20-25 notches of E, A and L lobes.

\section{Type material}

Holotype

IRAN • East Azerbaijan, Ali Bashi Mountains; Ali Bashi Formation; illustrated by Teichert \& Kummel in Teichert et al. (1973: pl. 3 figs 1-2); MCZ 9678.

\section{Material examined}

IRAN • 30 specimens; Esfahan Province, Baghuk Mountain 1 section; Hambast Formation; MB.C.29664 to MB.C.29669 - 4 specimens; Esfahan Province, Baghuk Mountain B section; Hambast Formation; MB.C.29670 to MB.C.29673 12 specimens; Esfahan Province, Baghuk Mountain E section; Hambast Formation; MB.C.29674 to MB.C.29678 • 2 specimens; Esfahan Province, Baghuk Mountain G section; Hambast Formation; MB.C.29679 - 33 specimens; Esfahan Province, Baghuk Mountain H section; Hambast Formation; MB.C.29680 to MB.C.29687 • 92 specimens; Esfahan Province, Baghuk Mountain; Hambast Formation; MB.C.29688 to MB.C.29712.

\section{Description}

There is little morphological variation in the material when the conch proportions are regarded. specimen MB.C.29674 is an incomplete but comparatively well-preserved specimen with $52 \mathrm{~mm}$ diameter (Fig. 17A). It is extremely discoidal $(\mathrm{ww} / \mathrm{wh}=0.24)$ and evolute $(\mathrm{uw} / \mathrm{dm}=0.48)$ with a compressed, parallel-sided whorl profile with flat venter and an angular ventrolateral shoulder. The sculpture consists, on the last volution of the phragmocone as well as the body chamber, of sharp and slightly sigmoidal ribs on the flanks; on half a volution around 20 of such ribs can be counted.

The suture line of specimen MB.C.29674 has a short external lobe with concave flanks and bifid prongs (Fig. 17D). The ventrolateral saddle is asymmetric and appears dorsally inclined. The adventive lobe is semicircular in shape with twelve small notches of equal size. In contrast to this is the lateral lobe almost flat at its base; it is also serrated by numerous small notches.

There is some variation in the shape of the venter. In contrast to specimen MB.C.29674, the other two figured specimens MB.C.29672 (Fig. 17B) and MB.C.29670 (Fig. 17C) show a less flattened or even a rounded venter. These two specimens do not show as sharp ribs as specimen MB.C.29674.

\section{Remarks}

Shevyrevites shevyrevi differs from $S$. nodosus in the lack of the coarse nodes of the subadult stage and from $S$. corrugatus sp. nov. in the much coarser and less numerous ribs. 
Table 2. Conch dimensions (partly estimated) and ratios of selected specimens of Shevyrevites shevyrevi Teichert \& Kummel in Teichert et al. (1973) from Baghuk Mountain.

\begin{tabular}{ccccccccccc}
\hline Specimen & dm & ww & wh & uw & ah & ww/dm & ww/wh & uw/dm & WER & IZR \\
\hline MB.C.29674 & 52.1 & 12.3 & 15.4 & 24.8 & 15.2 & 0.24 & 0.80 & 0.48 & 1.99 & 0.01 \\
MB.C.29670 & 45.4 & 9.9 & 14.4 & 18.9 & 14.1 & 0.22 & 0.69 & 0.42 & 2.10 & 0.02 \\
MB.C.29672 & 43.8 & 11.2 & 13.4 & 20.9 & 13.0 & 0.26 & 0.84 & 0.48 & 2.02 & 0.03 \\
MB.C.29705.5 & 56.8 & 12.5 & 16.8 & 26.4 & 16.0 & 0.22 & 0.74 & 0.46 & 1.94 & 0.05 \\
MB.C.29676.2 & 54.3 & 12.8 & 17.2 & 25.3 & 16.6 & 0.24 & 0.74 & 0.47 & 2.07 & 0.03 \\
MB.C.29676.3 & 50.1 & 11.2 & 16.2 & 22.2 & 15.6 & 0.22 & 0.69 & 0.44 & 2.11 & 0.04 \\
MB.C.29676.1 & 48.8 & 12.5 & 15.5 & 23.3 & 15.0 & 0.26 & 0.81 & 0.48 & 2.08 & 0.03 \\
MB.C.29705.4 & 47.7 & 11.7 & 13.9 & 21.5 & 13.4 & 0.25 & 0.84 & 0.45 & 1.93 & 0.04 \\
MB.C.29693.1 & 46.8 & 10.7 & 13.2 & 22.2 & 12.5 & 0.23 & 0.81 & 0.47 & 1.86 & 0.05 \\
MB.C.29705.7 & 45.2 & 11.4 & 13.7 & 20.1 & 13.4 & 0.25 & 0.83 & 0.44 & 2.02 & 0.02 \\
MB.C.29676.4 & 45.0 & 11.7 & 12.9 & 22.4 & 12.3 & 0.26 & 0.91 & 0.50 & 1.89 & 0.05 \\
MB.C.29704.1 & 35.6 & 9.2 & 9.5 & 17.9 & 9.2 & 0.26 & 0.97 & 0.50 & 1.82 & 0.03 \\
\hline
\end{tabular}
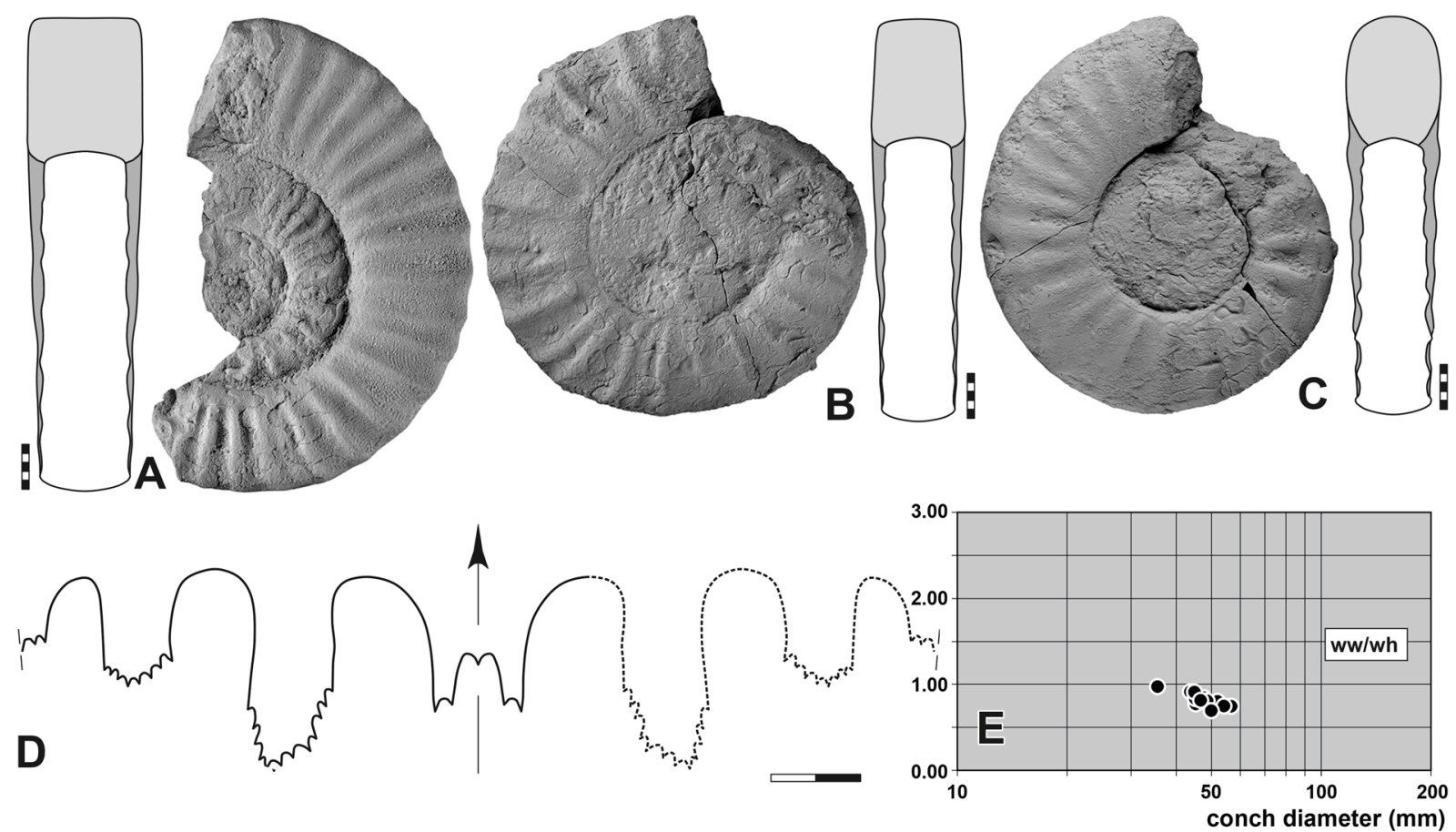

Fig. 17. Shevyrevites shevyrevi Teichert \& Kummel in Teichert et al., 1973. A. Lateral and dorsal view, specimen MB.C.29674, section E, float. B. Lateral and dorsal view, specimen MB.C.29672, section B, float. C. Lateral and dorsal view, specimen MB.C.29670, section B, float. D. Suture line, specimen MB.C.29674, at $10.8 \mathrm{~mm}$ ww, $13.0 \mathrm{~mm}$ wh. E. Whorl profile proportions. Abbreviations: see Material and methods. Scale bar units $=1 \mathrm{~mm}$. 


\section{Stratigraphic range}

Upper part of the Hambast Formation; 5.20 to $4.70 \mathrm{~m}$ below the extinction horizon (Shevyrevites shevyrevi Zone).

Shevyrevites nodosus (Shevyrev, 1965)

Fig. 18; Table 3

Bernhardites nodosus Shevyrev, 1965: 171, pl. 21 fig. 8.

Bernhardites nodosus - Shevyrev 1968: 87, pl. 2 fig. 2.

Shevyrevites nodosus - Korn et al. 2019: 46, text-fig. 13.

non Shevyrevites nodosus - Korn in Ghaderi et al. 2014: text-fig. 7d.

\section{Diagnosis}

Species of Shevyrevites with conch reaching $80 \mathrm{~mm} \mathrm{dm}$. Subadult stage with circular, slightly compressed whorl profile $(\mathrm{ww} / \mathrm{wh}=0.60-0.75)$ and rounded venter; 10 coarse lateral nodes per volution. Adult stage with parallel-sided, slightly compressed whorl profile $(\mathrm{ww} / \mathrm{wh}=0.60-0.75)$, flattened venter and subangular ventrolateral shoulder; radial plications. Prongs of external lobe simple or bifid; altogether about 15 notches of $\mathrm{E}, \mathrm{A}$ and $\mathrm{L}$ lobes.

\section{Type material}

\section{Holotype}

ARMENIA • Ogbin; Late Permian; illustrated by Shevyrev (1965: pl. 24 fig. 1); PIN 1478/31.

\section{Material examined}

IRAN • 1 specimen; Esfahan Province, Baghuk Mountain C section; Hambast Formation; MB.C.29713 • 1 specimen; Esfahan Province, Baghuk Mountain E section; Hambast Formation; MB.C.29714 • 1 specimen; Esfahan Province, Baghuk Mountain G section; Hambast Formation; MB.C.29715 • 2 specimens; Esfahan Province, Baghuk Mountain; Hambast Formation; MB.C.29716 to MB.C.29717.

\section{Description}

Specimen MB.C.29713 has $53 \mathrm{~mm}$ diameter and shows the partly crushed phragmocone and less than half a volution of the terminal body chamber (Fig. 18). The whorl profile of the body chamber is

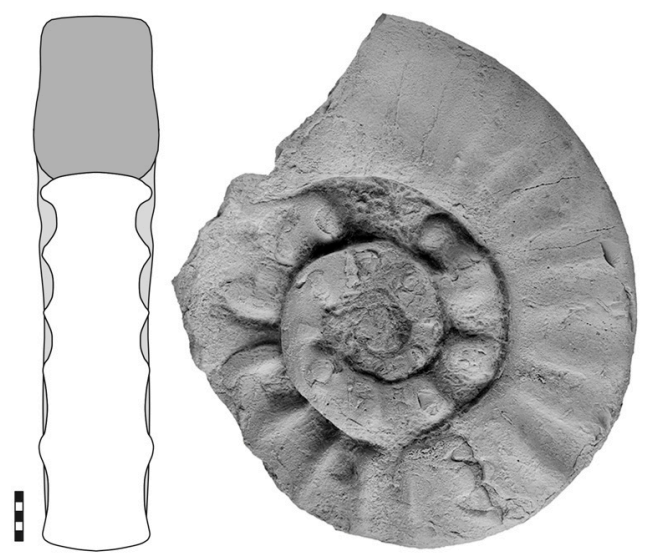

Fig. 18. Shevyrevites nodosus (Shevyrev, 1965), lateral and reconstructed dorsal view of specimen MB.C.29713. Scale bar units $=1 \mathrm{~mm}$. 
Table 3. Conch dimensions (partly estimated) and ratios of selected specimens of Shevyrevites nodosus Shevyrev, 1965 from Baghuk Mountain.

\begin{tabular}{ccccccccccc}
\hline Specimen & $\mathbf{d m}$ & $\mathbf{w w}$ & $\mathbf{w h}$ & $\mathbf{u w}$ & $\mathbf{a h}$ & $\mathbf{w w} / \mathbf{d m}$ & $\mathbf{w w} / \mathbf{w h}$ & $\mathbf{u w} / \mathbf{d m}$ & WER & IZR \\
\hline MB.C.29713 & 53.2 & 11.9 & 15.6 & 24.8 & 15.2 & 0.22 & 0.76 & 0.47 & 1.96 & 0.03 \\
MB.C.29714 & 45.1 & 9.9 & 14.8 & 23.6 & 14.0 & 0.22 & 0.67 & 0.52 & 2.10 & 0.05 \\
\hline
\end{tabular}

subtrapezoidal with weakly converging flanks, a subangular ventrolateral shoulder and a flattened venter. The sculpture of the phragmocone differs significantly from the body chamber; while the phragmocone bears coarse conical nodes (10 per volution) and later elongate sharp ribs on the midflank, the body chamber has weak and blunt radial ribs. Only portions of the suture line can be seen on the flank; they show a finely serrated adventive lobe.

\section{Remarks}

Shevyrevites nodous differs in the coarse lateral nodes of the subadult stage from $S$. shevyrevi and S. corrugatus sp. nov.

\section{Stratigraphic range}

Upper part of the Hambast Formation; $4.45 \mathrm{~m}$ below the extinction horizon (Shevyrevites nodosus Zone).

Shevyrevites corrugatus Korn \& Hairapetian sp. nov. urn:1sid:zoobank.org:act:89B3129F-6478-4C46-9CD6-DDCD7C735BF0

Fig. 19; Table 4

\section{Diagnosis}

Species of Shevyrevites with conch reaching $60 \mathrm{~mm} \mathrm{dm}$. Subadult stage with oval, slightly compressed whorl profile $(\mathrm{ww} / \mathrm{wh}=0.60-0.75)$ and rounded venter; multiple fine ribs. Adult stage with parallelsided, slightly compressed whorl profile $(\mathrm{ww} / \mathrm{wh}=0.60-0.75)$, rounded venter and rounded ventrolateral shoulder; multiple fine riblets on the flank. Prongs of external lobe bifid; altogether 11 notches of E, A and L lobes.

\section{Etymology}

From the Latin 'corrugatus', meaning 'folded', because of the corrugate sculpture.

\section{Material examined}

\section{Holotype}

IRAN • Esfahan Province, Baghuk Mountain A section; Hambast Formation; illustrated in Fig. 19B; MB.C.29718.

\section{Paratype}

IRAN • 1 specimen; Esfahan Province, Baghuk Mountain A section; Hambast Formation; MB.C.29719; illustrated in Fig. 19A.

\section{Description}

Holotype MB.C. 29718 has $37 \mathrm{~mm}$ conch diameter and shows half of a volution preserved that belongs to the terminal body chamber (Fig. 19B); the maximum phragmocone diameter is $27 \mathrm{~mm}$. The phragmocone 
Table 4. Conch dimensions (partly estimated) and ratios of selected specimens of Shevyrevites corrugatus Korn \& Hairapetian sp. nov. from Baghuk Mountain.

\begin{tabular}{ccccccccccc}
\hline Specimen & $\mathbf{d m}$ & ww & wh & uw & ah & ww/dm & ww/wh & uw/dm & WER & IZR \\
\hline MB.C.29719 & 41.1 & 9.3 & 12.8 & 18.2 & - & 0.23 & 0.73 & 0.44 & - & - \\
MB.C.29718 & 36.7 & 7.3 & 11.5 & 15.7 & 10.2 & 0.20 & 0.63 & 0.43 & 1.92 & 0.11 \\
\hline
\end{tabular}

shows rather densely spaced septa (18 per volution), but the last four are then strikingly crowded and indicate adulthood. The conch is extremely discoidal $(\mathrm{ww} / \mathrm{dm}=0.20)$ and subevolute $(\mathrm{uw} / \mathrm{dm}=0.43)$ with applanate flanks and a rounded venter. The sculpture consists of numerous densely spaced and sharp radial riblets (about 30 on half a volution in the adult stage), which on the body chamber extend with a shallow concave sinus across the flanks.

The suture line of the holotype has a nearly parallel-sided, weakly pouched external lobe that is almost as deep as the adventive lobe; it has asymmetric prongs that are subdivided by two notches. The slightly asymmetric ventrolateral saddle is inverted U-shaped and followed by the asymmetric adventive lobe with five small notches, an asymmetric lateral saddle and an asymmetric lateral lobe with four notches (Fig. 19C).

\section{Remarks}

The new species differs from the other species of Shevyrevites by the much weaker sculpture, which consists of feeble riblets in contrast to the coarser ribs in $S$. shevyrevi and the conical nodes in $S$. nodosus.

\section{Stratigraphic range}

Upper part of the Hambast Formation; float but probably $4.80 \mathrm{~m}$ below the extinction horizon (red nodular limestone in the Shevyrevites shevyrevi Zone).

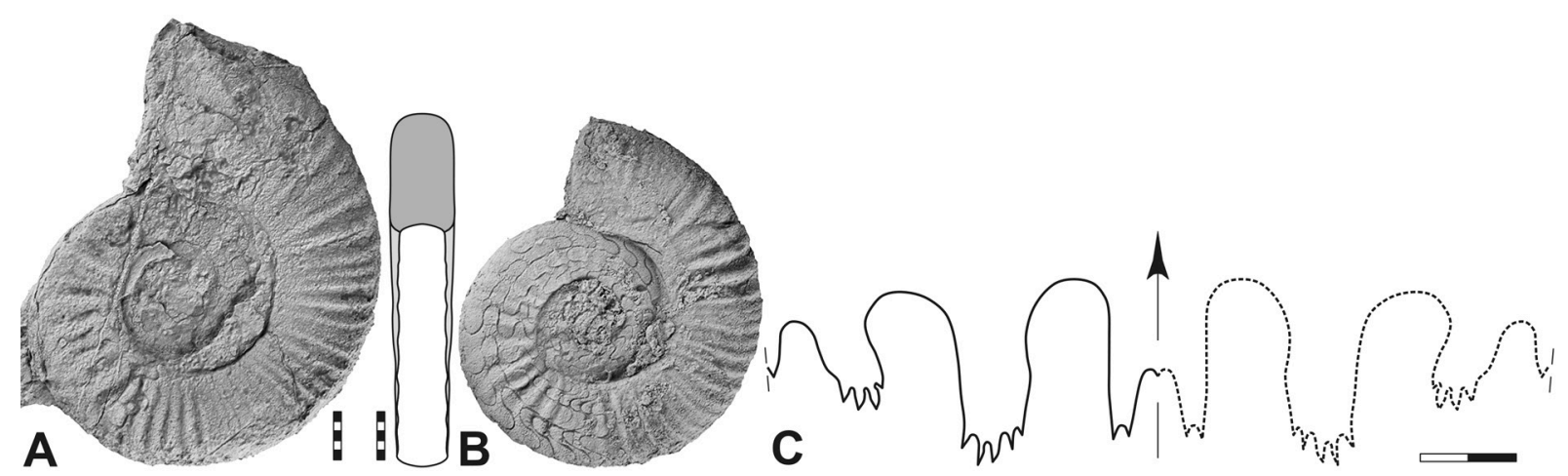

Fig. 19. Shevyrevites corrugatus Korn \& Hairapetian sp. nov. A. Lateral and dorsal view, paratype MB.C.29719, section A, float. B. Lateral and dorsal view, holotype MB.C.29718, section A, float. C. Suture line, holotype MB.C.29718, at $9.4 \mathrm{~mm}$ wh. Abbreviation: see Material and methods. Scale bar units $=1 \mathrm{~mm}$. 


\section{Type species}

Genus Arasella Korn in Ghaderi et al., 2014

Sinoceltites? minutus Zakharov in Kotlyar et al., 1983, by original designation

\section{Included species}

Sinoceltites? minutus Zakharov in Kotlyar et al., 1983; Arasella falcata Korn \& Hairapetian sp. nov.

\section{Remarks}

The genus Arasella is somewhat problematic because of its very simple suture line; an unambiguous attribution to a distinct family is therefore difficult. The shape of the external lobe rather speaks for placing it in the family Xenodiscidae rather than the Dzhulfitidae. The shape of the conch and the sculpture are similar to the early Changhsingian Shevyrevites, but this genus has multidentate adventive and lateral lobes.

Arasella minuta (Zakharov, 1983)

Fig. 20; Table 5

Sinoceltites? minutus Zakharov in Kotlyar et al., 1983: 153, pl. 15 fig. 1, 2.

Arasella minuta - Korn in Ghaderi et al. 2014: text-fig. 7I. - Korn \& Ghaderi in Korn et al. 2016: 887, text-fig. 44.

\section{Diagnosis}

Species of Arasella with conch reaching $35 \mathrm{~mm} \mathrm{dm}$. Subadult and adult stage with circular whorl profile $(\mathrm{ww} / \mathrm{wh}=0.85-1.05)$ and rounded venter; 20-22 sharp ribs on the flanks. External lobe with V-shaped prongs; adventive and lateral lobes broadly rounded.

\section{Type material}

\section{Holotype}

AZERBAIJAN • Nakhichevan Province, Akhura; probably top of the Paratirolites Limestone; illustrated by Zakharov (in Kotlyar et al. 1983: pl. 15 fig. 1); BPI 4/813.

\section{Material examined}

IRAN • 1 specimen; Esfahan Province, Baghuk Mountain C section; Hambast Formation; MB.C.29720 • 3 specimens; Esfahan Province, Baghuk Mountain E section; Hambast Formation; MB.C.29721 to MB.C.29723 - 8 specimens; Esfahan Province, Baghuk Mountain G section; Hambast Formation; MB.C.29724 to MB.C.29729 • 1 specimen; Esfahan Province, Baghuk Mountain H section; Hambast Formation; MB.C.29730 - 2 specimens; Esfahan Province, Baghuk Mountain; Hambast Formation; MB.C.29731 to MB.C.29732.

\section{Description}

Specimen MB.C.29720 has $25 \mathrm{~mm}$ conch diameter and is moderately well preserved (Fig. 20A). Less than half of the last volution belongs to the body chamber. The extremely and evolute conch (uw/ $\mathrm{dm}=0.48$ ) shows a nearly circular whorl profile of the body chamber. The sculpture of the phragmocone and the terminal body chamber does not differ markedly; the phragmocone has slightly coarser but more rounded radial and sharp ribs on the flank, while the ribs on the body chamber are sharper and coarsest in the ventrolateral area. There are about 15 ribs per half volution. 
Table 5. Conch dimensions (partly estimated) and ratios of selected specimens of Arasella minuta (Zakharov in Kotlyar et al. 1983) from Baghuk Mountain.

\begin{tabular}{ccccccccccc}
\hline Specimen & $\mathbf{d m}$ & $\mathbf{w w}$ & $\mathbf{w h}$ & $\mathbf{u w}$ & $\mathbf{a h}$ & $\mathbf{w w} / \mathbf{d m}$ & $\mathbf{w w} / \mathbf{w h}$ & $\mathbf{u w} / \mathbf{d m}$ & WER & IZR \\
\hline MB.C.29732 & 27.5 & 7.1 & 7.3 & 13.3 & 6.8 & 0.26 & 0.97 & 0.48 & 1.76 & 0.07 \\
MB.C.29720 & 25.5 & - & 6.9 & 12.1 & 6.7 & - & - & 0.48 & 1.84 & 0.03 \\
\hline
\end{tabular}

\section{Remarks}

Species of Arasella minuta can easily be separated from all other contemporaneous ammonoids from the Iranian localities because of its very simple suture line with rounded adventive and lateral lobes and the short external lobe (Korn et al. 2016). Arasella falcata sp. nov. possesses a much weaker sculpture with ribs coarsest in in dorsolateral area.

\section{Stratigraphic range}

Topmost part of the Hambast Formation; immediately below the extinction horizon (Arasella minuta Zone).
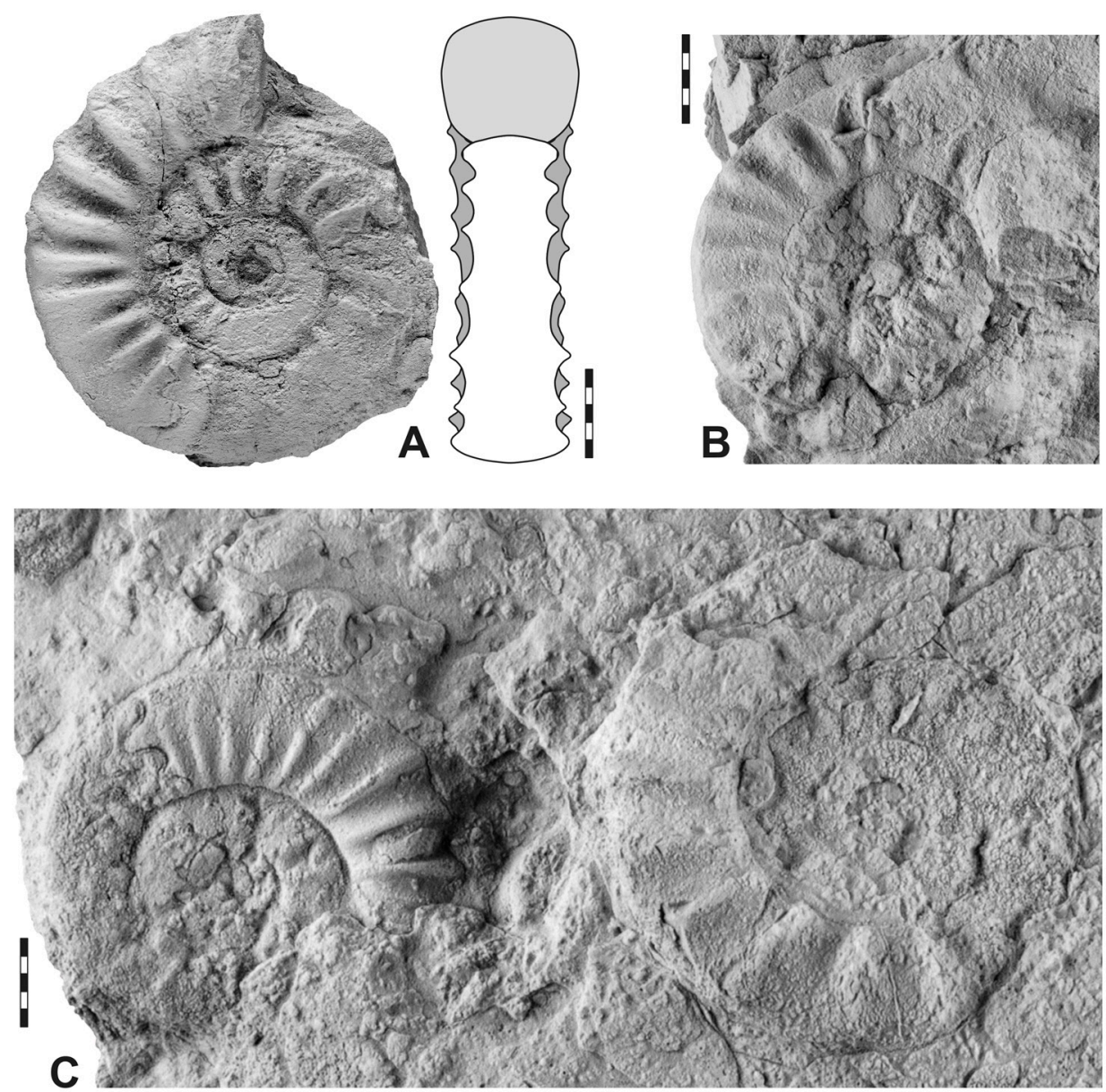

Fig. 20. Arasella minuta (Zakharov, 1983). A. Lateral and dorsal view, specimen MB.C.29720, section C, -0.05 m. B. Lateral view, specimen MB.C.29728, section G, -0.05 m. C. Arasella falcata Korn \& Hairapetian sp. nov.; right = specimen MB.C.29731; left=paratype MB.C.29737, section C, -0.05 m. Scale bar units $=1 \mathrm{~mm}$. 
Arasella falcata Korn \& Hairapetian sp. nov.

urn:Isid:zoobank.org:act:B2DA940A-842C-452B-8906-A29E07291FFE

Fig. 21; Table 6

\section{Diagnosis}

Species of Arasella with conch reaching $35 \mathrm{~mm} \mathrm{dm}$. Subadult and adult stage with compressed whorl profile $(\mathrm{ww} / \mathrm{wh}=0.60-0.70)$ and rounded venter; 25 curved ribs which are coarsest on the inner flanks.

\section{Etymology}

From the Latin 'falx', meaning 'sickle', because of the rib course.

\section{Material examined}

\section{Holotype}

IRAN - Esfahan Province, Baghuk Mountain C section; Hambast Formation, $0.05 \mathrm{~m}$ below top; illustrated in Fig. 21A; MB.C.29734.

\section{Paratypes}

IRAN 1 specimen; Esfahan Province, Baghuk Mountain 1 section; Hambast Formation; MB.C.29733 • 1 specimen; Esfahan Province, Baghuk Mountain G section; Hambast Formation; MB.C.29735 •
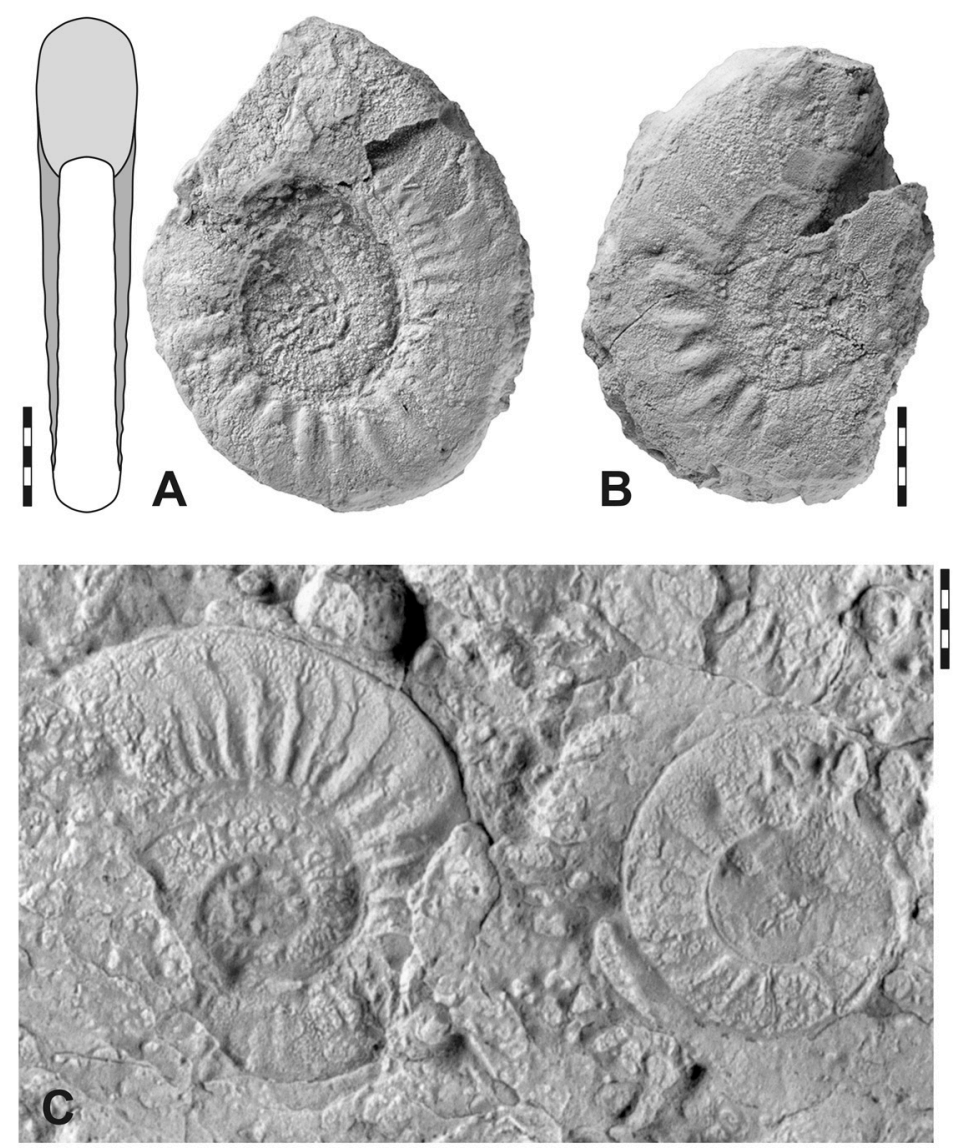

Fig. 21. Arasella falcata Korn \& Hairapetian sp. nov. A. Lateral and dorsal view, holotype MB.C.29734, section C, $-0.05 \mathrm{~m}$. B. Lateral view, paratype MB.C.29733, section 1, $-0.05 \mathrm{~m}$. C. Lateral views, paratype MB.C.29736, section H, $-0.05 \mathrm{~m}$. Scale bar units $=1 \mathrm{~mm}$. 
Table 6. Conch dimensions (partly estimated) and ratios of selected specimens of Arasella falcata Korn \& Hairapetian sp. nov. from Baghuk Mountain.

\begin{tabular}{ccccccccccc}
\hline Specimen & $\mathbf{d m}$ & $\mathbf{w w}$ & $\mathbf{w h}$ & $\mathbf{u w}$ & $\mathbf{a h}$ & $\mathbf{w w} / \mathbf{d m}$ & $\mathbf{w w} / \mathbf{w h}$ & $\mathbf{u w} / \mathbf{d m}$ & WER & IZR \\
\hline MB.C.29734 & 25.1 & 5.1 & 8.1 & 10.4 & 7.1 & 0.20 & 0.63 & 0.41 & 1.94 & 0.12 \\
MB.C.29734 & 18.0 & 3.6 & 5.8 & 7.7 & - & 0.20 & 0.62 & 0.43 & - & - \\
\hline
\end{tabular}

1 specimen; Esfahan Province, Baghuk Mountain H section; Hambast Formation; MB.C.29736 • 1 specimen; Esfahan Province, Baghuk Mountain; Hambast Formation; MB.C.29737.

\section{Description}

Holotype MB.C.29734 is a somewhat corroded specimen with a conch diameter of $24 \mathrm{~mm}$ (Fig. 21A). It is extremely discoidal $(\mathrm{ww} / \mathrm{dm}=0.20)$ and subevolute $(\mathrm{uw} / \mathrm{dm}=0.43)$ with a compressed whorl profile $(\mathrm{ww} / \mathrm{wh}=0.63)$. The flanks are nearly parallel and the venter is rounded. The last volution shows about 25 ribs, which are sharpest and coarsest on the inner flank; they turn slightly forward and become weaker on the outer flank to diminish.

\section{Remarks}

Arasella minuta shows much coarser ribs, particularly on the outer flanks, while A. falcata sp. nov. possesses a much weaker sculpture with ribs strongest in in dorsolateral area.

\section{Stratigraphic range}

Topmost part of the Hambast Formation; immediately below the extinction horizon (Arasella minuta Zone).

Family Dzhulfitidae Shevyrev, 1965

For the composition and diagnosis of the family, see Korn \& Ghaderi in Korn et al. (2016).

Genus Dzhulfites Shevyrev, 1965

\section{Type species}

Dzhulfites spinosus Shevyrev, 1965, by original designation.

\section{Included species}

Dzhulfites hebes Korn \& Ghaderi in Korn et al. (2016); Dzhulfites nodosus Shevyrev, 1965;

Dzhulfites spinosus Shevyrev, 1965; Dzhulfites zalensis Korn \& Ghaderi in Korn et al. (2016); Dzhulfites brevisellatus Korn \& Hairapetian sp. nov.

\section{Diagnosis}

Representatives of the family Dzhulfitidae with moderately large to large conch; maximum adult diameters are between 80 and $160 \mathrm{~mm}$. Subadult stage with trapezoidal whorl profile, adult stage variable. Subadult stage with small to large conical ventrolateral nodes, adult stage with weakening sculpture. Suture line with external lobe that does not reach the depth of the adventive lobe; prongs of external lobe simple to trifid.

\section{Remarks}

For a discussion of the genus, see Korn \& Ghaderi in Korn et al. (2016). 
Dzhulfites spinosus Shevyrev, 1965

Fig. 22; Table 7

Dzhulfites spinosus Shevyrev, 1965: 173, pl. 21 fig. 9, pl. 22 fig. 1.

Dzhulfites spinosus - Shevyrev 1968: 88, pl. 2 figs 3-4. - Korn et al. 2019: 51, text-figs 20-21.

\section{Diagnosis}

Species of Dzhulfites with conch reaching $90 \mathrm{~mm} \mathrm{dm}$. Subadult stage with weakly trapezoidal, moderately depressed whorl profile (ww/wh $=1.50-1.60)$ and broadly rounded venter; $6-8$ coarse conical nodes on midflank per volution. Prongs of external lobe simple to trifid; altogether 14-18 notches of E, A and L lobes.

\section{Type material}

\section{Holotype}

AZERBAIJAN - Nakhichevan Province, Dorasham 2 section; Late Permian; illustrated by Shevyrev (1965: pl. 21 fig. 9); PIN 1478/60.

\section{Material examined}

IRAN • 1 specimen; Esfahan Province, Baghuk Mountain 1 section; Hambast Formation; MB.C.29738 • 1 specimen; Esfahan Province, Baghuk Mountain A section; Hambast Formation; MB.C.29739 • 1 specimen; Esfahan Province, Baghuk Mountain B section; Hambast Formation; MB.C.29740 • 2 specimens; Esfahan Province, Baghuk Mountain E section; Hambast Formation; MB.C.29741 to MB.C.29742 - 1 specimen; Esfahan Province, Baghuk Mountain G section; Hambast Formation; MB.C.29743 - 2 specimens; Esfahan Province, Baghuk Mountain G section; Hambast Formation; MB.C.29744 to MB.C.29745.

\section{Description}

Specimen MB.C.29739 has a conch diameter of $47 \mathrm{~mm}$, but the beginning of the terminal body chamber is already at $31 \mathrm{~mm}$, as indicated by two narrowly spaced septa (Fig. 22B). The weakly corroded specimen shows a ww/wh ratio of 1.50 at $32 \mathrm{~mm} \mathrm{dm}$; the whorl profile is trapezoidal with broadly rounded venter. The sculpture possesses six as well as eight conical midflank nodes on the last two volutions of the phragmocone, respectively.

The suture line of specimen MB.C.29739 has an external lobe that is almost as deep as the adventive lobe; it possesses three small notches. There follow an inverted U-shaped ventrolateral saddle and an adventive lobe that is widest at its base. It has about eight small notches. The parallel-sided lateral saddle is lower than the ventrolateral saddle and the lateral lobe, subdivided by seven very small notches, is only half as deep as the adventive lobe (Fig. 22F).

Specimen MB.C.29743 is a specimen with $48 \mathrm{~mm}$ conch diameter and has a phragmocone diameter of $36 \mathrm{~mm}$ (Fig. 22C). Its body chamber has a rounded-trapezoidal, weakly depressed whorl profile (ww/ $w h=1.30$ ) with broadly rounded venter. In the subadult stage, the ww/wh ratio is higher than 1.50 and the whorl profile has a depressed oval shape. The sculpture in the subadult stage has eight coarse and pointed conical midflank nodes per volution; these nodes become much weaker on the body chamber and are replaced by weak, radial ribs, which are coarsest in the ventrolateral region.

The suture line of specimen MB.C.29743 differs from the preceding in the simple, unsubdivided prongs of the external lobe that is not as deep as the adventive lobe, the inflated ventrolateral saddle and the wider lateral saddle (Fig. 22E). 

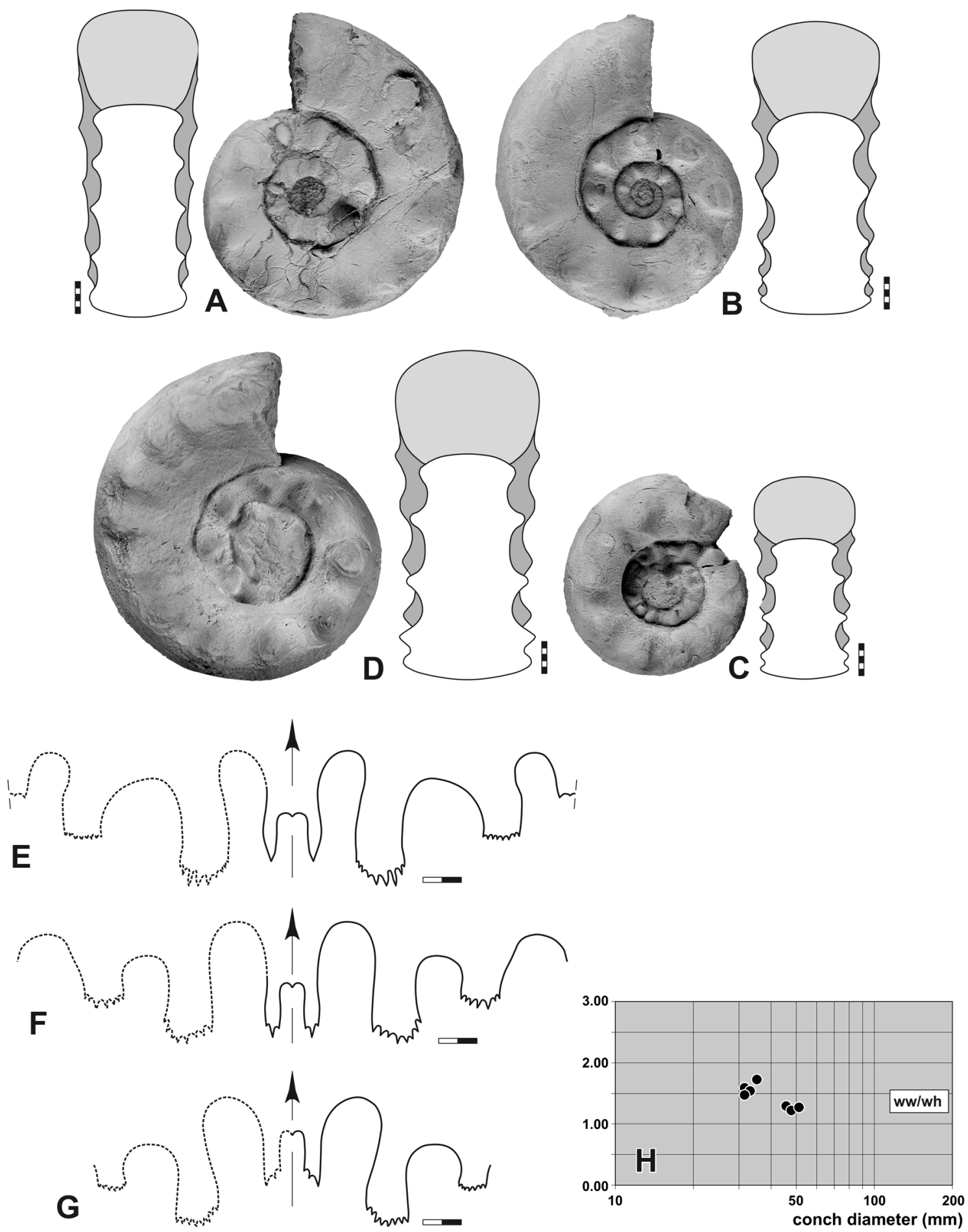

Fig. 22. Dzhulfites spinosus Shevyrev, 1965. A-D. Lateral and dorsal views. A. Specimen MB.C.29741, section E, float. B. Specimen MB.C.29739, float. C. Specimen MB.C.29743, section G, float. D. Specimen MB.C.29744, section H, -5.40 m. E-G. Suture lines. E. Specimen MB.C.29743, at $32.5 \mathrm{~mm} \mathrm{dm}, 16.5 \mathrm{~mm}$ ww, $10.5 \mathrm{~mm}$ wh. F. Holotype. MB.C. 29739 , at $32.0 \mathrm{~mm} \mathrm{dm}, 16.0 \mathrm{~mm}$ ww, $10.0 \mathrm{~mm}$ wh. G. Specimen MB.C.29744, at $29.5 \mathrm{~mm} \mathrm{dm}, 16.5 \mathrm{~mm}$ ww, $9.7 \mathrm{~mm}$ wh. H. Whorl profile proportions. Abbreviations: see Material and methods. Scale bar units $=1 \mathrm{~mm}$. 
Table 7. Conch dimensions (partly estimated) and ratios of selected specimens of Dzhulfites spinosus Shevyrev, 1965 from Baghuk Mountain.

\begin{tabular}{ccccccccccc}
\hline Specimen & dm & ww & wh & uw & ah & ww/dm & ww/wh & uw/dm & WER & IZR \\
\hline MB.C.29743 & 51.4 & 22.5 & 17.8 & 21.7 & 15.8 & 0.44 & 1.26 & 0.42 & 2.08 & 0.11 \\
MB.C.29741 & 48.0 & 18.9 & 15.6 & 21.2 & 14.8 & 0.39 & 1.21 & 0.44 & 2.09 & 0.05 \\
MB.C.29739 & 45.8 & 19.9 & 15.5 & 20.0 & 14.5 & 0.43 & 1.28 & 0.44 & 2.14 & 0.06 \\
MB.C.29744 & 31.6 & 15.8 & 10.8 & 13.2 & - & 0.50 & 1.46 & 0.42 & - & - \\
\hline
\end{tabular}

The suture line of the smaller specimen MB.C.29744 is remarkable because of its asymmetric external lobe with one prong being unsubdivided and the other possessing three small notches. It shows a narrow, dorsally inclined and weakly inflated ventrolateral saddle and a multiply serrated, asymmetric adventive lobe that is widest at its base (Fig. 22G).

\section{Remarks}

Dzhulfites spinosus differs most of the other species of Dzhulfites in the shape of the venter, which is broadly rounded in the new species but more or less flattened in D. nodosus and D. zalensis. Dzhulfites hebes is a very similar species in conch proportions and sculpture, but differs in the coarser, blunt nodes of the sculpture. Paratirolites kittli is a species with similar conch morphology, but possesses a deep external lobe, which is much shorter in D. spinosus.

\section{Stratigraphic range}

Upper part of the Hambast Formation; 7.00 to $4.70 \mathrm{~m}$ below the extinction horizon (Dzhulfites spinosus Zone to Shevyrevites shevyrevi Zone).

Dzhulfites brevisellatus Korn \& Hairapetian sp. nov. urn:1sid:zoobank.org:act:1FDCA9D7-546A-48FA-94E1-0053EB7F7C23

Fig. 23; Table 8

\section{Diagnosis}

Species of Dzhulfites with conch reaching $160 \mathrm{~mm} \mathrm{dm}$. Subadult stage with weakly trapezoidal, moderately depressed whorl profile (ww/wh $=1.50-1.80)$ and broadly rounded venter; $10-13$ coarse conical nodes on midflank per volution. Adult stage with numerous weak ribs and small ventrolateral nodes. Prongs of external lobe bifid or trifid; altogether 15-20 notches of E, A and L lobes.

\section{Etymology}

From the Latin 'brevis', meaning 'low' and 'sella', meaning 'saddle', after the low amplitude of lobes and saddles in the suture line.

\section{Material examined}

\section{Holotype}

IRAN - Esfahan Province, Baghuk Mountain H section; Hambast Formation, $5.70 \mathrm{~m}$ below top; illustrated in Fig. 23B; MB.C.29748.

\section{Paratypes}

IRAN • 1 specimen; Esfahan Province, Baghuk Mountain; Hambast Formation; MB.C.29746 • 1 specimen; Esfahan Province, Baghuk Mountain E section; Hambast Formation; MB.C.29747. 
KORN D. et al., Ammonoids from Baghuk Mountain

Table 8. Conch dimensions (partly estimated) and ratios of selected specimens of Dzhulfites brevisellatus Korn \& Hairapetian sp. nov. from Baghuk Mountain.

\begin{tabular}{ccccccccccc}
\hline Specimen & $\mathbf{d m}$ & $\mathbf{w w}$ & $\mathbf{w h}$ & $\mathbf{u w}$ & $\mathbf{a h}$ & $\mathbf{w w} / \mathbf{d m}$ & $\mathbf{w w} / \mathbf{w h}$ & $\mathbf{u w} / \mathbf{d m}$ & WER & IZR \\
\hline MB.C.29746 & 124.0 & - & 39.0 & 61.0 & 37.0 & - & - & 0.49 & 2.03 & 0.05 \\
MB.C.29748 & 50.4 & 25.1 & 16.6 & 21.7 & 15.0 & 0.50 & 1.51 & 0.43 & 2.03 & 0.10 \\
\hline
\end{tabular}

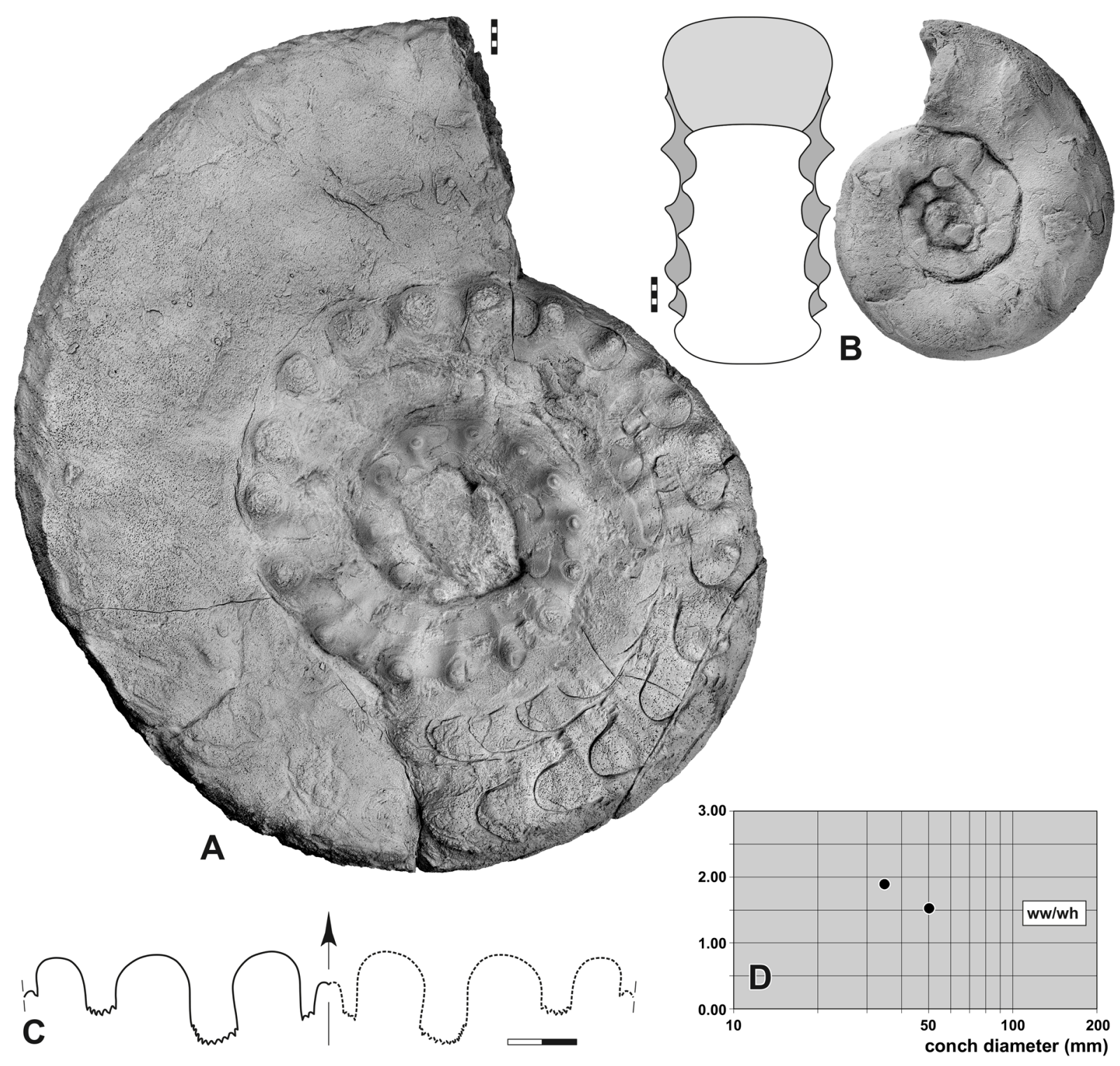

Fig. 23. Dzhulfites brevisellatus Korn \& Hairapetian sp. nov. A-B. Lateral and dorsal views. A. Paratype MB.C.29746, float. B. Holotype MB.C.29748, section H, -5.70 m. C. Suture line, holotype MB.C.29748, at $21.0 \mathrm{~mm}$ ww, $13.5 \mathrm{~mm}$ wh. D. Whorl profile proportions. Abbreviations: see Material and methods. Scale bar units $=1 \mathrm{~mm}$. 


\section{Description}

The large paratype MB.C.29746 has $125 \mathrm{~mm}$ conch diameter, of which half of the last whorl belongs to the strongly weathered body chamber (Fig. 23A). The phragmocone is $90 \mathrm{~mm}$ in diameter and is partly crushed; it shows that the whorl profile is trapezoidal with a broadly rounded venter. The sculpture changes dramatically throughout ontogeny. At $40 \mathrm{~mm}$ dm there are 13 coarse, spiny ventrolateral nodes per volution; these nodes become weaker and more numerous so that the last $120^{\circ}$ of the phragmocone have about 20 weak ventrolateral nodes, which are connected with weak and slightly sinuous radial ribs on the flank. The suture line of the specimen suffered from weathering, but, most probably, the prongs of the very short external lobe are bifid.

Holotype MB.C.29748 is a fairly well-preserved, fully septate specimen with $51 \mathrm{~mm}$ conch diameter (Fig. 23B). It has a weakly trapezoidal whorl profile with broadly rounded flanks and venter. The sculpture shows about ten coarse conical nodes, which are positioned on the midflank, on the last preserved volution.

The suture line of the holotype shows an external lobe with subparallel, weakly diverging flanks and weakly asymmetric, trifid prongs. All three saddles of the outer suture line are similar in shape, being inverted U-shaped and broadly rounded. The adventive lobe and the lateral lobe are similar in shape with parallel flanks and many small notches at the base. They differ in their depth; the adventive lobe is much deeper than the external lobe (Fig. 23C).

\section{Remarks}

Among the species of Dzhulfites, only D. nodosus is similar in conch shape and sculpture, but this species shows an applanate venter in the adult stage. Dzhulfites brevisellatus sp. nov. differs from D. spinosus and the other species of the genus in the suture line, which in D. brevisellatus sp. nov. shows much wider elements; particularly the saddles are wider than the lobes. In the shape of the suture line, D. brevisellatus sp. nov. has some resemblance to representatives of the family Xenodiscidae.

\section{Stratigraphic range}

Upper part of the Hambast Formation; 5.70 to 4.70 m below the extinction horizon (Dzhulfites spinosus Zone to Shevyrevites shevyrevi Zone).

Genus Paratirolites Stoyanow, 1910

\section{Type species}

Paratirolites Kittli Stoyanow, 1910, by original designation.

\section{Included species}

Paratirolites birunii Korn \& Ghaderi, 2016; Paratirolites coronatus Korn \& Ghaderi, 2016; Paratirolites kittli Stoyanow, 1910; Paratirolites multiconus Korn \& Ghaderi in Korn et al., 2016; Paratirolites quadratus Korn \& Ghaderi in Korn et al., 2016; Paratirolites serus Korn \& Ghaderi in Korn et al., 2016; Paratirolites trapezoidalis Shevyrev, 1965; Paratirolites vediensis Shevyrev, 1965; Stephanites (?) Waageni Stoyanow, 1910; Azerbaijan (synonym of Paratirolites kittli Stoyanow, 1910); Paratirolites rubens Korn \& Hairapetian sp. nov.; Paratirolites lanceolobatus Korn \& Hairapetian sp. nov.; Paratirolites robustus Korn \& Hairapetian sp. nov.; Paratirolites baghukensis Korn \& Hairapetian sp. nov.; Paratirolites aduncus Korn \& Hairapetian sp. nov. 


\section{Diagnosis}

Representatives of the family Dzhulfitidae with moderately large to very large conch; maximum adult diameters between 60 and $250 \mathrm{~mm}$. Adult stage with trapezoidal whorl profile. Subadult stage with large conical ventrolateral nodes; adult stage with significantly weakening sculpture. Suture line with deep external lobe; depths of external lobe and adventive lobe are nearly identical.

\section{Remarks}

For a discussion of the genus, see Korn \& Ghaderi in Korn et al. (2016).

Paratirolites rubens Korn \& Hairapetian sp. nov. urn:1sid:zoobank.org:act:C8D262EC-926D-4CAB-AE08-BB8C158CE276

Fig. 24; Table 9

\section{Diagnosis}

Species of Paratirolites with conch reaching $110 \mathrm{~mm} \mathrm{dm}$. Subadult stage with broadly oval, moderately depressed whorl profile $(\mathrm{ww} / \mathrm{wh}=1.60)$ and broadly rounded venter; about 8 coarse ventrolateral nodes per volution. Adult stage with broadly oval, weakly depressed whorl profile (ww/wh $=1.30)$, broadly rounded venter and rounded ventrolateral shoulder; coarse ventrolateral nodes. Prongs of external lobe unserrated; altogether 16 notches of $\mathrm{E}, \mathrm{A}$ and $\mathrm{L}$ lobes.

\section{Etymology}

From the Latin 'rubens', meaning 'red', because of the red limestone horizon where the material comes from.

\section{Material examined}

Holotype

IRAN - Esfahan Province, Baghuk Mountain E section; Hambast Formation; illustrated in Fig. 24; MB.C.29749.

\section{Paratype}

IRAN • 1 specimen; Esfahan Province, Baghuk Mountain E section; Hambast Formation; MB.C.29750.

\section{Description}

Holotype MB.C.29749 is a rather well-preserved individual of $50 \mathrm{~mm}$ conch diameter (Fig. 24A). It is fully chambered with septal crowing at the end; therefore the adult diameter including body chamber has been about $90 \mathrm{~mm}$. The whorl profile is, at $50 \mathrm{~mm}$ conch diameter, broadly oval (ww/wh $=1.80$ ) with broadly convex flanks and venter. Half a volution earlier, the ww/wh ratio is even higher (1.90). The sculpture consists of eight coarse conical nodes with a position on the midflank of the last volution; the penultimate volution bears only six nodes.

The suture line of the holotype has a narrow external lobe that is wider near its base and weakly constricted in the upper part. It possesses very narrow, non-serrated prongs. A narrow and slightly inflated ventrolateral saddle and an asymmetric adventive lobe with ten little notches follow on the sides of the venter, while the continuously rounded lateral saddle and the nearly symmetric lateral lobe (with five small notches) have a position on the flank (Fig. 24B).

\section{Remarks}

Paratirolites rubens sp. nov. is the species of the genus with the lowest number of ventrolateral nodes. Furthermore, the broadly rounded venter is a criterion of clear separation from species such as $P$. vediensis 
Table 9. Conch dimensions (partly estimated) and ratios of selected specimens of Paratirolites rubens Korn \& Hairapetian sp. nov. from Baghuk Mountain.

\begin{tabular}{ccccccccccc}
\hline Specimen & $\mathbf{d m}$ & ww & wh & uw & ah & ww/dm & ww/wh & uw/dm & WER & IZR \\
\hline MB.C.29749 & 51.2 & 24.4 & 18.3 & 20.3 & 16.3 & 0.48 & 1.33 & 0.40 & 2.15 & 0.11 \\
MB.C.29749 & 34.9 & 19.9 & 12.6 & 14.2 & - & 0.57 & 1.58 & 0.41 & - & - \\
\hline
\end{tabular}
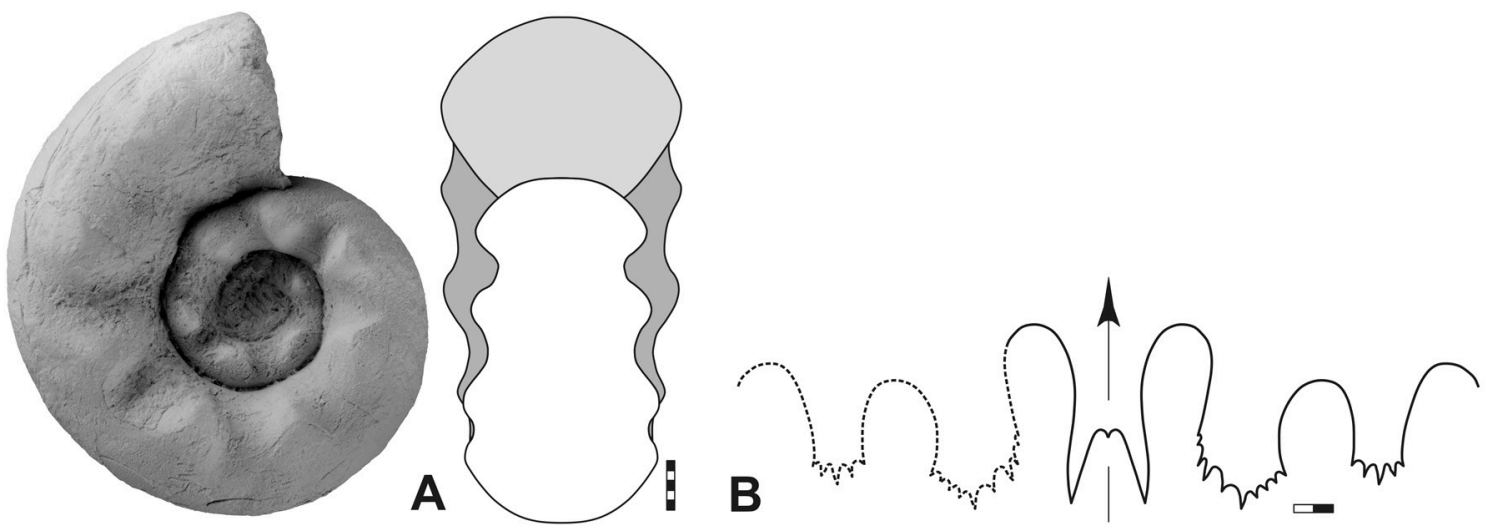

Fig. 24. Paratirolites rubens Korn \& Hairapetian sp. nov. A. Lateral and dorsal view, holotype MB.C.29749, section E, float. B. Suture line, holotype MB.C.29749, at $36.0 \mathrm{~mm} \mathrm{dm,} 22.0 \mathrm{~mm}$ ww, $13.0 \mathrm{~mm}$ wh. Abbreviations: see Material and methods. Scale bar units $=1 \mathrm{~mm}$.

and $P$. kittli. There is also some similarity to the species Dzhulfites spinosus and D. hebes, but these differ in the very short external lobe.

\section{Stratigraphic range}

None of the specimens was collected in situ, but according to the intensive red colour of the host sediment, a position in the Hambast Formation about five metres below the extinction horizon is most likely (probably Shevyrevites shevyrevi Zone).

Paratirolites lanceolobatus Korn \& Hairapetian sp. nov. urn:1sid:zoobank.org:act:EA9569C5-F88F-4487-A528-878A60FB4CE1

Fig. 25; Table 10

\section{Diagnosis}

Species of Paratirolites with conch reaching $90 \mathrm{~mm}$ dm. Subadult stage with weakly trapezoidal, weakly depressed whorl profile $(\mathrm{ww} / \mathrm{wh}=1.10-1.30)$ and broadly rounded venter; about 12 radial ribs ending in coarse conical ventrolateral nodes per volution. Adult stage with rectangular and weakly compressed whorl profile ( $\mathrm{ww} / \mathrm{wh}=0.85-1.00$ ), flattened, weakly tectiform venter and subangular ventrolateral shoulder; numerous rounded ventrolateral nodes. Prongs of external lobe lanceolate and usually unsubdivided; altogether 11-15 notches of E, A and L lobes. 


\section{Etymology}

From the Latin' lancea', meaning 'lance', because of the lanceolate prongs of the external lobe.

\section{Material examined}

\section{Holotype}

IRAN - Esfahan Province, Baghuk Mountain B section; Hambast Formation; illustrated in Fig. 25A; MB.C.29769.

\section{Paratypes}

IRAN • 18 specimens; Esfahan Province, Baghuk Mountain 1 section; Hambast Formation; MB.C.29751 to MB.C.29768 - 3 specimens; Esfahan Province, Baghuk Mountain E section; Hambast Formation; MB.C.29770 to MB.C.29772 1 specimen; Esfahan Province, Baghuk Mountain G section; Hambast Formation; MB.C.29773 - 2 specimens; Esfahan Province, Baghuk Mountain; Hambast Formation; MB.C.29774 to MB.C.29775.

\section{Description}

Holotype MB.C.29769 is a comparatively well-preserved individual with $73 \mathrm{~mm}$ conch diameter; a little more than half of the last whorl belongs to the partly corroded body chamber. The last two and a half whorls of the phragmocone are better preserved (Fig. 25A). The beginning of the terminal body chamber is at $50 \mathrm{~mm}$ diameter; it is well identifiable by the crowding of two septa. This boundary is not identical with spontaneous changes in conch shape and sculpture. At the beginning of the body chamber, the whorl profile is trapezoidal with a flattened, broadly rounded venter; at the end, the whorl profile is slightly trapezoidal with weakly diverging flanks. The rounded, weakly tectiform venter is delimited from the flanks by rounded ventrolateral shoulders. The sculpture shows three ontogenetic stages: (1) The inner whorls (up to $10 \mathrm{~mm} \mathrm{dm}$ ) appear to be smooth without ribs or nodes. (2) The intermediate stage (between 10 and $50 \mathrm{~mm} \mathrm{dm}$ ) shows radial ribs that end in coarse conical ventrolateral nodes (12 per volution in the smaller growth stage and more densely arranged in the larger stage), which weaken at the beginning of the body chamber. (3) The main portion of the body chamber shows smoothening of the sculpture.

The suture line of holotype MB.C.29769 possesses a parallel-sided external lobe with very narrow, lanceolate non-serrated prongs. The ventrolateral saddle is rather narrow (much narrower than the external lobe) and weakly inflated; it is followed by a rather broad, drop-shaped adventive lobe that is multiply serrated, a wide and broadly rounded lateral saddle and a V-shaped, weakly serrated lateral lobe (Fig. 25E).

The smaller paratype MB.C.29770 with $55 \mathrm{~mm}$ conch diameter resembles the holotype in conch proportions and sculpture, but appears to enter the adult growth stage at a smaller conch diameter with a maximum phragmocone diameter of $38 \mathrm{~mm}$ (Fig. 25C). Very coarse ventrolateral nodes are present in an interval of about 270 degrees of the phragmocone. The suture line of this specimen also shows nonserrated prongs of the external lobe.

Suture lines of the further two paratypes MB.C.29751 and MB.C.29757 (both at about $11 \mathrm{~mm}$ whorl height) demonstrate, when compared with the holotype, the variability within the Material examined

Common to all three specimens are the simple prongs of the external lobe, which in the paratypes MB.C.29751 and MB.C.29757 is less deep as the adventive lobe. All three specimens show an asymmetric adventive lobe that appears to be dorsally inclined (Fig. 25E-G). 
Table 10. Conch dimensions (partly estimated) and ratios of selected specimens of Paratirolites lanceolobatus Korn \& Hairapetian sp. nov. from Baghuk Mountain.

\begin{tabular}{ccccccccccc}
\hline Specimen & $\mathbf{d m}$ & ww & wh & uw & ah & ww/dm & ww/wh & uw/dm & WER & IZR \\
\hline MB.C.29769 & 73.3 & 22.6 & 26.6 & 29.6 & 24.1 & 0.31 & 0.85 & 0.40 & 2.22 & 0.09 \\
MB.C.29751 & 65.2 & 19.5 & 22.3 & 29.5 & 20.5 & 0.30 & 0.87 & 0.45 & 2.13 & 0.08 \\
MB.C.29770 & 53.5 & 17.8 & 17.9 & 24.1 & 16.5 & 0.33 & 0.99 & 0.45 & 2.09 & 0.08 \\
MB.C.29752 & 51.9 & 16.2 & 17.4 & 21.4 & 16.0 & 0.31 & 0.93 & 0.41 & 2.09 & 0.08 \\
MB.C.29773 & 51.5 & 17.9 & 16.4 & 23.7 & 15.8 & 0.35 & 1.09 & 0.46 & 2.08 & 0.04 \\
MB.C.29757 & 51.2 & - & 17.2 & 22.7 & 16.7 & - & - & 0.44 & 2.20 & 0.03 \\
MB.C.29758 & 31.6 & 16.8 & 11.4 & 12.7 & 11.0 & 0.53 & 1.47 & 0.40 & 2.35 & 0.04 \\
\hline
\end{tabular}

\section{Remarks}

The new species shows some similarities to species of the genus Dzhulfites, particularly in the reduced depth of the external and lateral lobes. It may thus represent a link between the two genera. The low stratigraphic position at the base of the Paratirolites Limestone supports this hypothesis.

Paratirolites lanceolobatus sp. nov. differs in the non-serrated prongs of the external lobe from most of the other species of the genus. Similar species are the Transcaucasian P. trapezoidalis and P. birunii, but both possess an adult body chamber with numerous small nodes at the angular ventrolateral shoulder. Paratirolites robustus sp. nov. is the most similar of the Central Iranian species but differs in the wider whorl profile $(\mathrm{ww} / \mathrm{wh}=1.20$ at $70 \mathrm{~mm} \mathrm{dm})$ from P. lanceolobatus $\mathrm{sp}$. nov. $(\mathrm{ww} / \mathrm{wh}=0.85)$. Furthermore, P. robustus sp. nov. has bifid prongs of the external lobe.

\section{Stratigraphic range}

Upper part of the Hambast Formation; 3.85 to $2.80 \mathrm{~m}$ below the extinction horizon (Paratirolites lanceolobatus Zone to lower part of the Paratirolites kittli Zone).

Paratirolites robustus Korn \& Hairapetian $\mathrm{sp}$. nov. urn:1sid:zoobank.org:act:10C9CACF-9ED4-4E61-8140-FDBB70154F87

Figs 26-27; Table 11

\section{Diagnosis}

Species of Paratirolites with conch reaching $120 \mathrm{~mm} \mathrm{dm}$. Subadult stage with trapezoidal, weakly depressed whorl profile $(\mathrm{ww} / \mathrm{wh}=1.30-1.50)$ and rounded venter; $8-12$ coarse, radially elongated midflank nodes per volution. Adult stage with trapezoidal and weakly depressed whorl profile

Fig. 25 (next page). Paratirolites lanceolobatus Korn \& Hairapetian sp. nov. A-E. Lateral and dorsal views. A. Holotype MB.C.29769, section B, float. B. Paratype MB.C.29751, section 1, float. C. Paratype MB.C.29770, section E, -3.30 m. D. Paratype MB.C.29752, section A, float. E-H. Suture lines. E. Holotype MB.C.29769, at $13.5 \mathrm{~mm}$ wh. F. Paratype MB.C.29751, at $11.2 \mathrm{~mm}$ wh. G. Paratype MB.C.29757, at $11.2 \mathrm{~mm}$ wh. H. Paratype MB.C.29770, at $11.1 \mathrm{~mm}$ wh. I. Whorl profile proportions. Abbreviations: see Material and methods. Scale bar units $=1 \mathrm{~mm}$. 

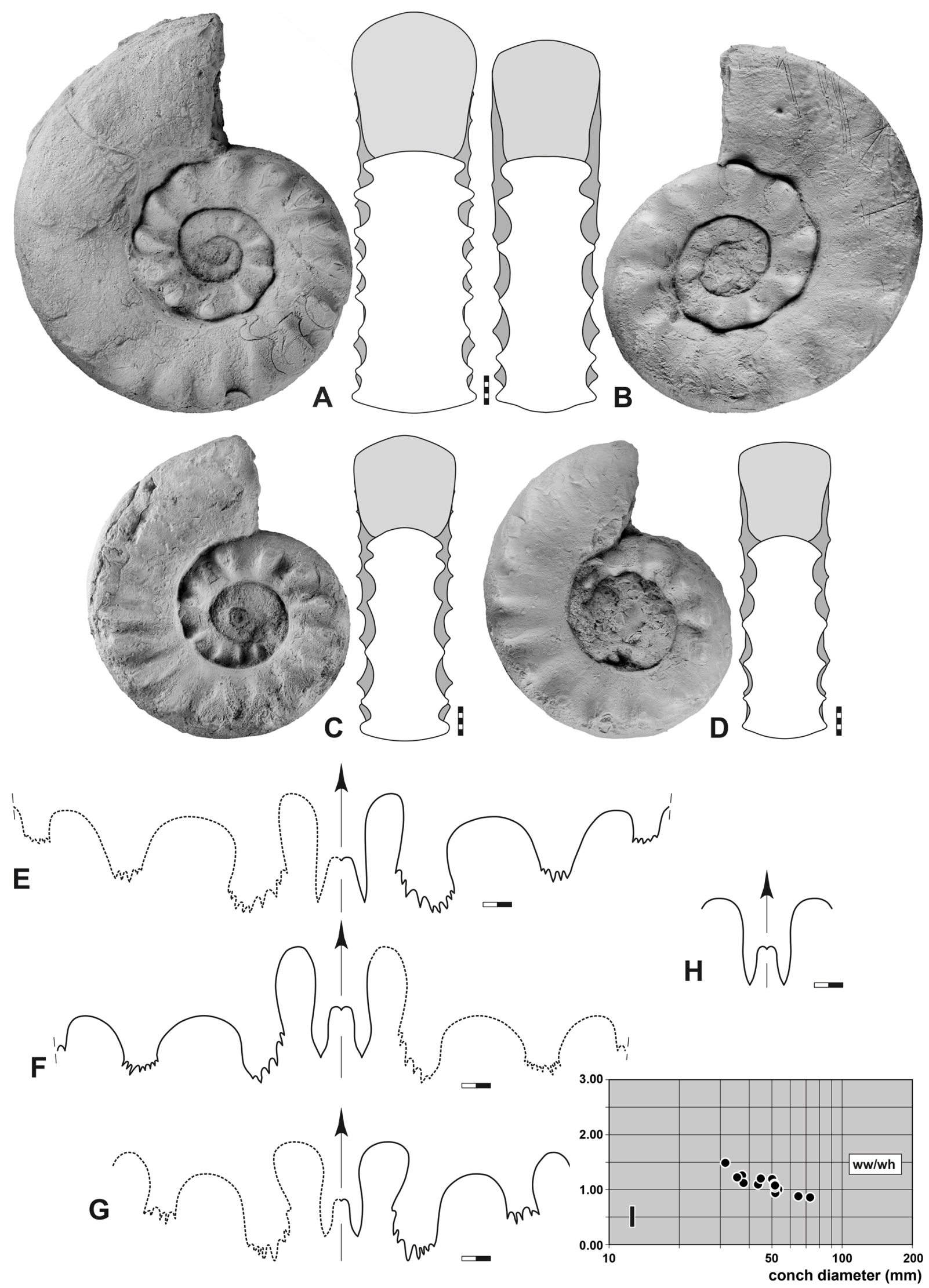
$(\mathrm{ww} / \mathrm{wh}=1.00-1.10)$, flattened, tectiform venter and angular ventrolateral shoulder; numerous weak ribs on flank. Prongs of external lobe simple to trifid; altogether 12-17 notches of E, A and L lobes.

\section{Etymology}

From the Latin 'robustus', meaning 'robust', because of the coarse ribs.

\section{Material examined}

\section{Holotype}

IRAN - Esfahan Province, Baghuk Mountain E section; Hambast Formation, $2.95 \mathrm{~m}$ below top; illustrated in Fig. 26A; MB.C.29778.
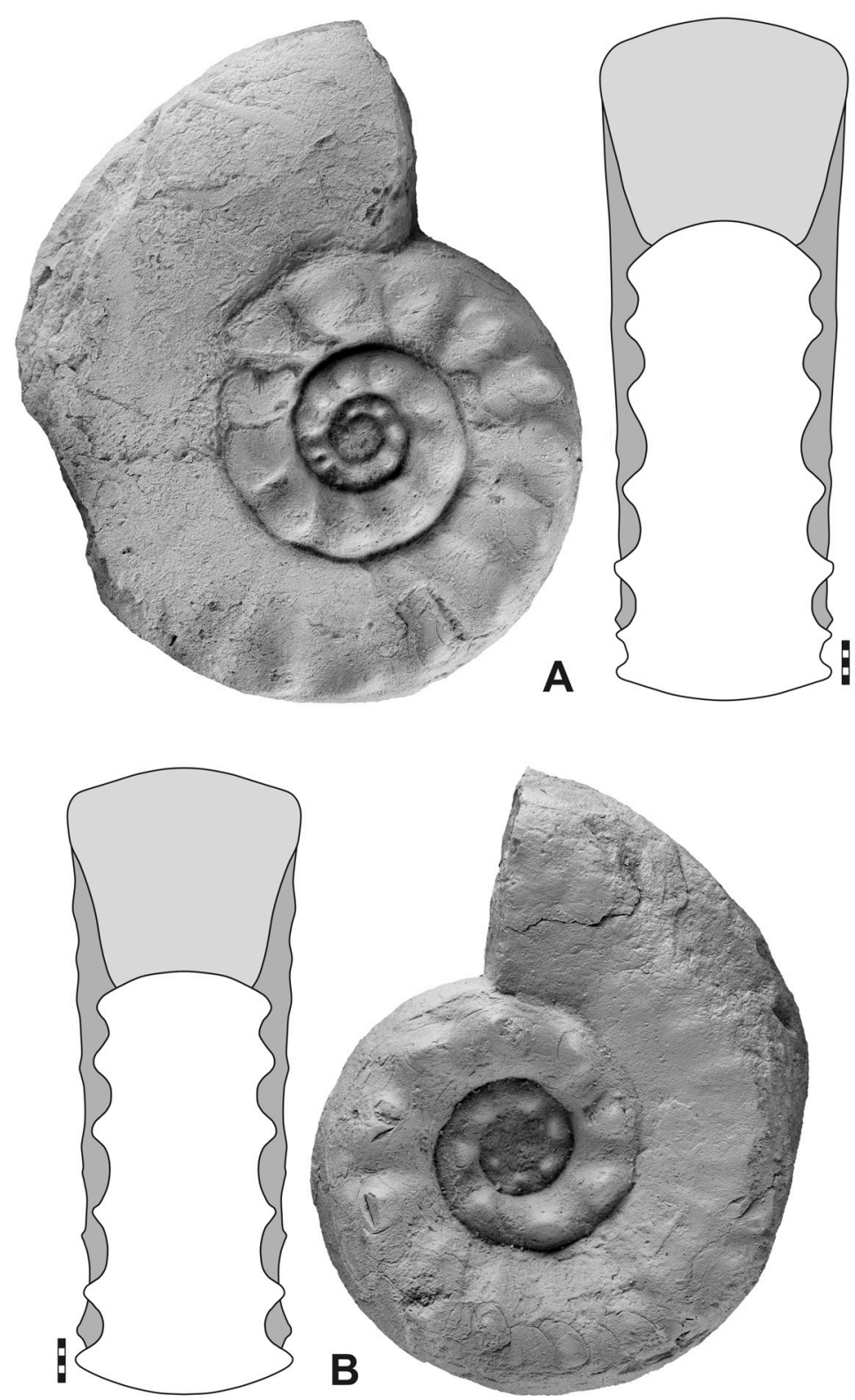

Fig. 26. Paratirolites robustus Korn \& Hairapetian sp. nov., lateral and dorsal views. A. Holotype MB.C.29778, section E, -2.95 m. B. Paratype MB.C.29782, float. Scale bar units=1 mm. 


\section{Paratypes}

IRAN • 2 specimens; Esfahan Province, Baghuk Mountain E section; Hambast Formation; MB.C.29776 to MB.C.29777 - 1 specimen; Esfahan Province, Baghuk Mountain E section; Hambast Formation; MB.C.29779 - 1 specimen; Esfahan Province, Baghuk Mountain G section; Hambast Formation; MB.C.29780 • 4 specimens; Esfahan Province, Baghuk Mountain; Hambast Formation; MB.C.29781 to MB.C.29784.

\section{Description}

Holotype MB.C. 29778 has $80 \mathrm{~mm}$ conch diameter and consists of a rather well-preserved phragmocone and a more or less strongly weathered body chamber (Fig. 26A). Septal crowding indicates that the maximum phragmocone diameter is $48 \mathrm{~mm}$. The conch shape changes during growth; there is a strongly trapezoidal whorl profile of the phragmocone and a weakly trapezoidal profile of the body chamber. The sculpture of the phragmocone shows 12 conical nodes, which are circular and symmetric in section in the penultimate whorl but become asymmetric and radially elongated towards the end of the phragmocone.

The suture line of holotype MB.C.29778 has a Y-shaped external lobe, in which the prongs are weakly serrated including two notches. The adventive lobe is asymmetric and ventrally inclined with nearly parallel flanks and asymmetric notching. It is dorsolaterally followed by an asymmetric lateral saddle and a nearly symmetric lateral lobe with seven small notches (Fig. 27A).

The slightly smaller paratype MB.C.29782 $(73 \mathrm{~mm} \mathrm{dm})$ is very similar in conch shape and suture line. The penultimate whorl has eight coarse conical nodes, which transform, at the end of the phragmocone, into weakly curved elongated nodes (Fig. 26B). The suture line has an external lobe with weakly diverging
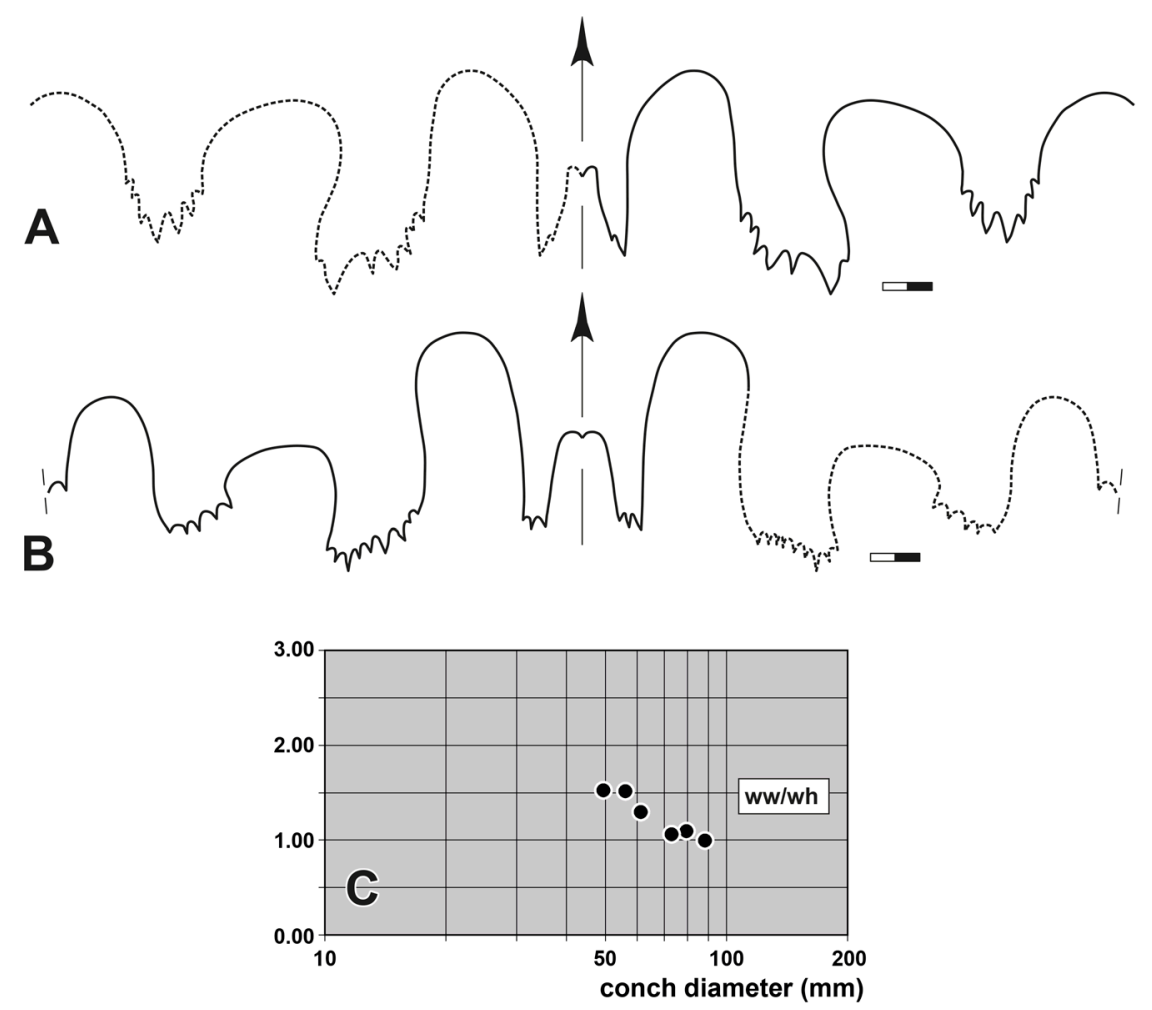

Fig. 27. Paratirolites robustus Korn \& Hairapetian sp. nov. A. Suture line, holotype MB.C.29778, at $14.2 \mathrm{~mm}$ wh. B. Suture line, paratype MB.C.29782, at $13.2 \mathrm{~mm}$ wh. C. Whorl profile proportions. Abbreviations: see Material and methods. Scale bar units $=1 \mathrm{~mm}$. 
Table 11. Conch dimensions (partly estimated) and ratios of selected specimens of Paratirolites robustus Korn \& Hairapetian sp. nov. from Baghuk Mountain.

\begin{tabular}{ccccccccccc}
\hline Specimen & dm & ww & wh & uw & ah & ww/dm & ww/wh & uw/dm & WER & IZR \\
\hline MB.C.29778 & 80.0 & 29.0 & 26.7 & 35.9 & 25.2 & 0.36 & 1.09 & 0.45 & 2.13 & 0.06 \\
MB.C.29782 & 73.4 & 27.4 & 26.0 & 30.9 & 24.2 & 0.37 & 1.05 & 0.42 & 2.23 & 0.07 \\
MB.C.29780 & 61.5 & 26.5 & 20.6 & 26.4 & - & 0.43 & 1.29 & 0.43 & - & - \\
\hline
\end{tabular}

flanks, an asymmetric ventrolateral saddle and a weakly asymmetric, strongly notched adventive lobe with nearly flat base and parallel flanks (Fig. 27B).

\section{Remarks}

Paratirolites robustus sp. nov. differs from the most similar of the Central Iranian species $P$. lanceolobatus sp. nov. in the stouter whorl profile (ww/wh $=1.20$ in P. robustus sp. nov. at $70 \mathrm{~mm}$ conch diameter and only 0.85 in P. lanceolobatus). Furthermore, P. lanceolobatus sp. nov. has non-serrated prongs of the parallel-sided external lobe. Paratirolites robustus sp. nov. differs from $P$. vediensis in the rounded venter and from $P$. kittli in the radially elongated nodes of the subadult stage and the presence of weak radial ribs of the body chamber.

\section{Stratigraphic range}

Upper part of the Hambast Formation; 3.20 to 2.90 m below the extinction horizon (uppermost part of the Paratirolites lanceolobatus Zone to Paratirolites kittli Zone).

Paratirolites vediensis Shevyrev, 1965

Figs 28-29; Table 12

Paratirolites vediensis Shevyrev, 1965: 176, pl. 23 fig. 1.

Paratirolites vediensis - Shevyrev 1968: 92, pl. 5 fig. 1. - Stepanov et al. 1969: pl. 13 fig. 5. - Korn in Ghaderi et al. 2014: text-fig. 7g. — Korn \& Ghaderi in Korn et al. 2016: 864, text-figs 23-24.

\section{Diagnosis}

Species of Paratirolites with conch reaching $250 \mathrm{~mm} \mathrm{dm}$. Subadult stage with trapezoidal, weakly depressed whorl profile ( $\mathrm{ww} / \mathrm{wh}=1.20-1.50)$ and flattened tectiform venter; $10-15$ coarse ventrolateral nodes per volution. Adult stage with strongly trapezoidal and weakly depressed whorl profile (ww/ $w h=1.00-1.20$ ), flattened tectiform venter and angular ventrolateral shoulder; weak ventrolateral nodes. Prongs of external lobe usually multiply serrated; altogether 12-20 notches of E, A and L lobes.

\section{Type material}

\section{Holotype}

ARMENIA - 1 specimen; Vedi; Paratirolites Limestone; illustrated by Shevyrev (1965: pl. 23 fig.1); PIN 1478/2.

\section{Material examined}

IRAN • 6 specimens; Esfahan Province, Baghuk Mountain 1 section; Hambast Formation; MB.C.29785 to MB.C.29790 - 1 specimen; Esfahan Province, Baghuk Mountain A section; Hambast Formation; MB.C.29791 - 4 specimens; Esfahan Province, Baghuk Mountain C section; Hambast Formation; MB.C.29792 to MB.C.29795 - 4 specimens; Esfahan Province, Baghuk Mountain E section; Hambast Formation; MB.C.29796 to MB.C.29799 • 6 specimens; Esfahan Province, Baghuk Mountain G section; 

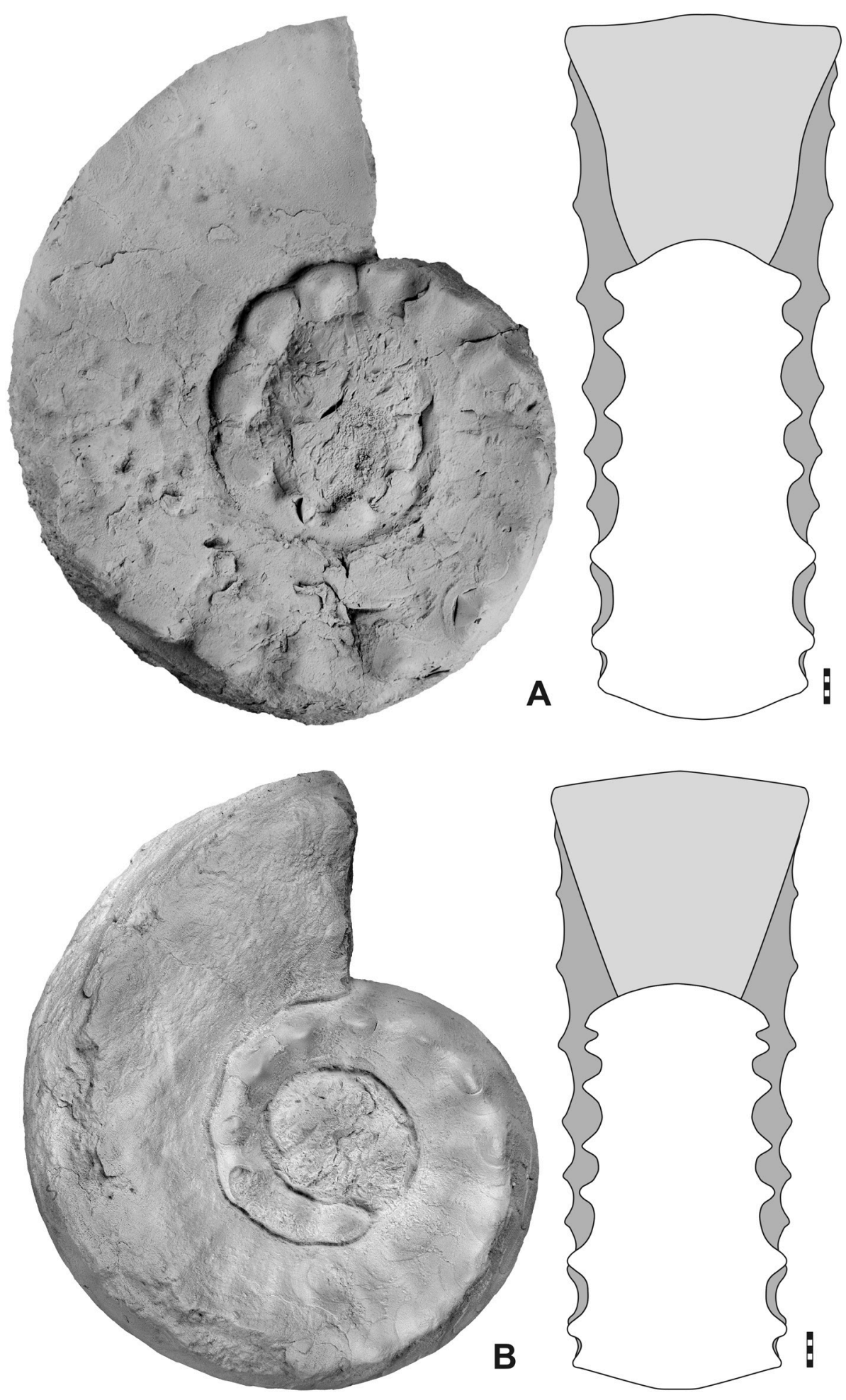

Fig. 28. Paratirolites vediensis Shevyrev, 1965, lateral and dorsal views. A. Specimen MB.C.29804, section G, -2.75 m. B. Specimen MB.C.29798, section E, float. Scale bar units=1 mm. 
Hambast Formation; MB.C.29800 to MB.C.29805 • 5 specimens; Esfahan Province, Baghuk Mountain H section; Hambast Formation; MB.C.29806 to MB.C.29810 • 2 specimens; Esfahan Province, Baghuk Mountain section; Hambast Formation; MB.C.29811 to MB.C.29812.

\section{Description}

Specimens MB.C.29811 and MB.C.29794 are the largest specimens with terminal phragmocone diameters of approximately $85 \mathrm{~mm}$. They indicate that the maximum diameter including body chamber has been about $155 \mathrm{~mm}$. Unfortunately, both specimens are poorly preserved.

Specimen MB.C.29804 (100 mm dm; Fig. 28A) shows septal crowding at a phragmocone diameter of $65 \mathrm{~mm}$, which means that the maximum conch diameter was approximately $120 \mathrm{~mm}$. It is slightly corroded but shows that the shape of the whorl profile is trapezoidal in the subadult and adult stage. The venter becomes flat with an angular ventrolateral shoulder during formation of the terminal body chamber but is more flattened in the phragmocone stage. The specimen shows a sculpture of the phragmocone that consists of 12 coarse conical nodes on the ventrolateral shoulder and both specimens demonstrate that these nodes become continuously weaker and more numerous (15 on half a volution in) on the body chamber. Specimen MB.C.29798 (88 mm dm; Fig. 28B) closely resembles specimen MB.C.29804 but possesses more longitudinally elongate ventrolateral spines.
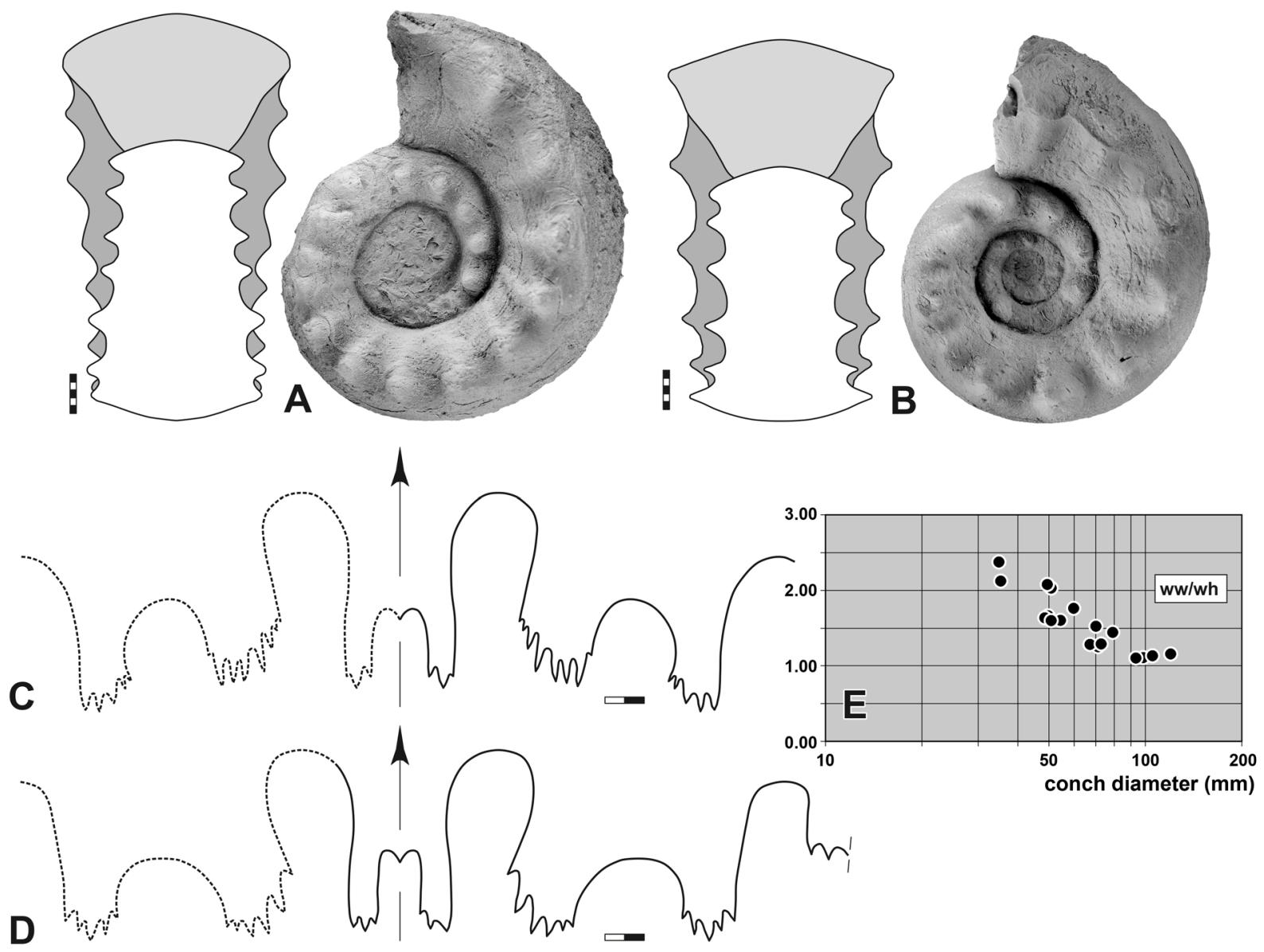

Fig. 29. Paratirolites vediensis Shevyrev, 1965. A-B. Lateral and dorsal views. A. Specimen MB.C.29792, section C, -2.75 m. B. Specimen MB.C.29785, section 1, -2.80 m. - C-D. Suture lines. C. Specimen MB.C.29792, at $13.0 \mathrm{~mm}$ wh. D. Specimen MB.C.29785, at $12.8 \mathrm{~mm}$ wh. - E. Whorl profile proportions. Abbreviations: see Material and methods. Scale bar units $=1 \mathrm{~mm}$. 
KORN D. et al., Ammonoids from Baghuk Mountain

Table 12. Conch dimensions (partly estimated) and ratios of selected specimens of Paratirolites vediensis Shevyrev, 1965 from Baghuk Mountain.

\begin{tabular}{ccccccccccc}
\hline Specimen & $\mathbf{d m}$ & $\mathbf{w w}$ & $\mathbf{w h}$ & $\mathbf{u w}$ & $\mathbf{a h}$ & $\mathbf{w w} / \mathbf{d m}$ & $\mathbf{w w} / \mathbf{w h}$ & uw/dm & WER & IZR \\
\hline MB.C.29804 & 99.2 & 38.8 & 35.2 & 40.0 & 31.5 & 0.39 & 1.10 & 0.40 & 2.15 & 0.11 \\
MB.C.29810 & 94.0 & 34.0 & 31.0 & 39.0 & 29.0 & 0.36 & 1.10 & 0.41 & 2.09 & 0.06 \\
MB.C.29795 & 79.5 & 38.0 & 26.5 & 33.2 & 24.2 & 0.48 & 1.43 & 0.42 & 2.07 & 0.09 \\
MB.C.29799 & 73.2 & 32.0 & 25.0 & 31.0 & 24.0 & 0.44 & 1.28 & 0.42 & 2.21 & 0.04 \\
MB.C.29801 & 71.5 & 32.0 & 25.7 & 29.3 & - & 0.45 & 1.25 & 0.41 & - & - \\
MB.C.29807 & 70.5 & 34.2 & 22.6 & 31.2 & 20.3 & 0.49 & 1.51 & 0.44 & 1.97 & 0.10 \\
MB.C.29792 & 49.9 & 27.9 & 16.9 & 22.0 & 15.5 & 0.56 & 1.65 & 0.44 & 2.10 & 0.08 \\
MB.C.29785 & 48.7 & 28.7 & 17.7 & 20.0 & 16.2 & 0.59 & 1.62 & 0.41 & 2.25 & 0.08 \\
MB.C.29794 & 121.0 & 46.0 & 40.0 & 52.0 & 36.0 & 0.38 & 1.15 & 0.43 & 2.03 & 0.10 \\
MB.C.29797 & 106.0 & 40.0 & 35.5 & 46.0 & 34.0 & 0.38 & 1.13 & 0.43 & 2.17 & 0.04 \\
MB.C.29798 & 89.0 & 31.5 & 31.8 & 34.7 & 30.5 & 0.35 & 0.99 & 0.39 & 2.31 & 0.04 \\
\hline
\end{tabular}

The two smaller specimens MB.C.29792 (Fig. 29A) and MB.C.29785 (Fig. 29B), both with about $50 \mathrm{~mm}$ conch diameter, are rather well preserved phragmocones. Both possess trapezoidal whorl profiles (ww/ $w h=1.65-1.75$ ) with strongly diverging flattened flanks, a subangular or angular ventrolateral shoulder and a slightly flattened, tectiform venter. The sculpture consists of 11 or 12 spiny ventrolateral nodes per volution, which begin as isolated nodes and develop to spiny nodes that show a rib-alike elongation toward the umbilicus.

The suture lines of the two specimens resemble each other (Fig. 29C-D) and possess a parallel-sided external lobe that is as deep as the adventive lobe. Its prongs are narrow and parallel-sided with three small notches. The ventrolateral saddle is inflated and asymmetric and the lateral saddle reaches only half the height of the ventrolateral saddle. The adventive lobe is asymmetric in both specimens and dorsally inclined; it is serrated with 6 and 8 little notches, respectively.

\section{Remarks}

The material from Baghuk Mountain closely resembles, in conch shape and ornament, the material from the type area near Julfa, but differs in the maximum conch size. While the maximum phragmocone diameter of the Julfa material ranges between 70 and $128 \mathrm{dm}$ (Korn \& Ghederi in Korn et al. 2016), the Baghuk Mountain material reaches $85 \mathrm{~mm}$ only.

Paratirolites vediensis differs from $P$. kittli in the strongly trapezoidal whorl profile with a flattened venter of the subadult stage, which shows a rounded venter in $P$. kittli. It differs from $P$. trapezoidalis, which possesses a very similar conch geometry, in the much coarser ribs of the adult stage (which in P. trapezoidalis are much more numerous and delicate), and in the stronger serrated prongs of the external lobes (usually multiply serrated in P. vediensis, but simple or bifid in P. trapezoidalis).

\section{Stratigraphic range}

Upper part of the Hambast Formation; 3.10 to 2.40 m below the extinction horizon (Paratirolites kittli Zone). 
Paratirolites kittli Stoyanow, 1910

Fig. 30; Table 13

Paratirolites Kittli Stoyanow, 1910: 82, pl. 9 figs 1-2.

Stephanites? Waageni Stoyanow, 1910: 89, pl. 8 fig. 3.

Pseudotirolites azariani Rostovtsev in Kotlyar et al., 1983: 154, pl. 15 fig. 5.

? Stephanites sp. indet. Stoyanow, 1910: 89, pl. 7 fig. 8.

Paratirolites kittli - Spath 1934: 366, text-fig. 125a-d. - Voinova et al. 1947: 169, pl. 40 fig. 4, textfig. 67. - Kummel 1957: 179, text-fig. 1a-b. - Shevyrev 1965: 174, pl. 22 fig. 4; 1968: 90, pl. 3

fig. 1. - Korn \& Ghaderi in Korn et al. 2016: 862, text-figs 20-22.

Paratirolites waageni-Spath 1934: 367. - Shevyrev 1965: 175, pl. 22 figs 5-6; 1968: 90, pl. 2 figs 6-7. Stephanites? waageni - Voinova et al. 1947: 167, pl. 40 fig. 3.

\section{Diagnosis}

Species of Paratirolites with conch reaching $190 \mathrm{~mm} \mathrm{dm}$. Subadult stage with rounded trapezoidal, weakly to moderately depressed whorl profile $(\mathrm{ww} / \mathrm{wh}=1.30-1.60)$ and rounded venter; $10-12$ very coarse ventrolateral nodes per volution. Adult stage with strongly trapezoidal and weakly depressed whorl profile $(\mathrm{ww} / \mathrm{wh}=1.00-1.30)$, flattened tectiform venter and subangular ventrolateral shoulder; weak ventrolateral nodes. Prongs of external lobe usually multiply serrated; altogether 12-21 notches of $\mathrm{E}, \mathrm{A}$ and $\mathrm{L}$ lobes.

\section{Material examined}

IRAN • 6 specimens; Esfahan Province, Baghuk Mountain 1 section; Hambast Formation; MB.C.29813 to MB.C.29818 - 1 specimen; Esfahan Province, Baghuk Mountain A section; Hambast Formation; MB.C.29819 - 1 specimen; Esfahan Province, Baghuk Mountain B section; Hambast Formation; MB.C.29820 - 5 specimens; Esfahan Province, Baghuk Mountain C section; Hambast Formation; MB.C.29821 to MB.C.29825 - 3 specimens; Esfahan Province, Baghuk Mountain E section; Hambast Formation; MB.C.29826 to MB.C.29828 - 1 specimen; Esfahan Province, Baghuk Mountain F section; Hambast Formation; MB.C.29829 - 6 specimens; Esfahan Province, Baghuk Mountain G section; Hambast Formation; MB.C.29830 to MB.C.29835 - 2 specimens; Esfahan Province, Baghuk Mountain H section; Hambast Formation; MB.C.29836 to MB.C.29837 • 4 specimens; Esfahan Province, Baghuk Mountain; Hambast Formation; MB.C.29838 to MB.C.29841.

\section{Description}

The large specimen MB.C.29833 (107 mm dm; Fig. 30A) shows septal crowding at a phragmocone diameter of $70 \mathrm{~mm}$, which indicates that the maximum conch diameter of this specimen was about $130 \mathrm{~mm}$. The body chamber of the specimen is corroded but shows that the shape of the whorl profile is trapezoidal in the subadult and adult stage. The venter becomes nearly flat with an angular ventrolateral shoulder during formation of the terminal body chamber but is broadly rounded in the phragmocone. This specimen shows a sculpture of the phragmocone that consist of 12 coarse conical nodes on the outer flanks. These nodes become continuously weaker on the terminal body chamber.

The suture line of specimen MB.C.29833 has an external lobe with weakly diverging flanks, nearly parallel-sided prongs with three small notches. The ventrolateral saddle is narrow and dorsally inclined; it continues into the strongly asymmetric adventive lobe, which is asymmetrically serrated with numerous small notches climbing high up the ventral flank. By contrast, the lateral lobe is trifid and nearly symmetric (Fig. 30B). 
Table 13. Conch dimensions (partly estimated) and ratios of selected specimens of Paratirolites kittli Stoyanow, 1910 from Baghuk Mountain.

\begin{tabular}{ccccccccccc}
\hline Specimen & dm & ww & wh & uw & ah & ww/dm & ww/wh & uw/dm & WER & IZR \\
\hline MB.C.29831 & 95.3 & 32.2 & 29.7 & 42.2 & 28.3 & 0.34 & 1.08 & 0.44 & 2.02 & 0.05 \\
MB.C.29833 & 106.5 & 40.7 & 35.0 & 46.6 & 33.7 & 0.38 & 1.16 & 0.44 & 2.14 & 0.04 \\
MB.C.29815 & 86.9 & - & 30.0 & 36.0 & 28.3 & - & - & 0.41 & 2.20 & 0.06 \\
MB.C.29818 & 71.0 & - & 24.5 & 31.2 & 23.5 & - & - & 0.44 & 2.23 & 0.04 \\
MB.C.29813 & 64.8 & - & 20.5 & 26.3 & 19.8 & - & - & 0.41 & 2.07 & 0.03 \\
MB.C.29821 & 56.0 & 32.8 & 20.6 & 21.0 & 19.0 & 0.59 & 1.59 & 0.38 & 2.29 & 0.08 \\
MB.C.29830 & 92.0 & - & 32.8 & 40.0 & 31.0 & - & - & 0.43 & 2.27 & 0.05 \\
\hline
\end{tabular}
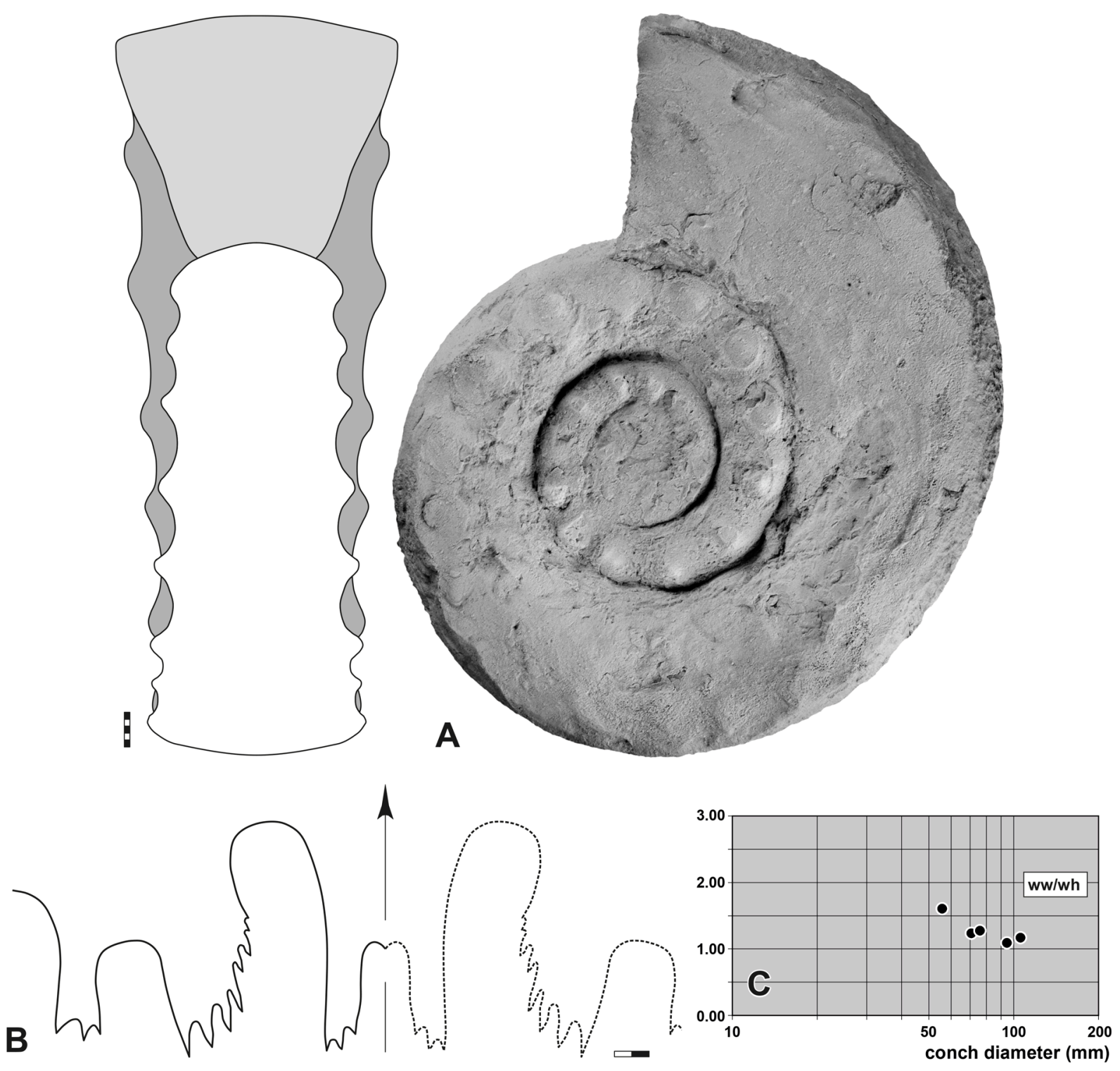

Fig. 30. Paratirolites kittli Stoyanow, 1910. A. Lateral and dorsal view, specimen MB.C.29833, section G, $-2.75 \mathrm{~m}$. B. Suture line, specimen MB.C.29833, at $30 \mathrm{~mm} w w, 16.0 \mathrm{~mm}$ wh. Abbreviations: see Material and methods. Scale bar units $=1 \mathrm{~mm}$. 


\section{Remarks}

Paratirolites kittli differs from the otherwise similar P. vediensis in the more rounded whorl profile of the subadult stage, which in the latter is trapezoidal with a flattened venter and flattened diverging flanks.

\section{Stratigraphic range}

Upper part of the Hambast Formation; 3.10 to 2.40 m below the extinction horizon (Paratirolites kittli Zone).

Paratirolites coronatus Korn \& Ghaderi in Korn et al., 2016

Fig. 31; Table 14

Paratirolites coronatus Korn \& Ghaderi in Korn et al., 2016: 860, text-figs 17-18.

\section{Diagnosis}

Species of Paratirolites with conch reaching $125 \mathrm{~mm} \mathrm{dm}$. Subadult stage with trapezoidal, moderately depressed whorl profile $(\mathrm{ww} / \mathrm{wh}=1.60-1.90)$ and flattened tectiform venter; 15 coarse conical ventrolateral nodes per volution. Adult stage with extremely trapezoidal and moderately depressed whorl profile ( $\mathrm{ww} / \mathrm{wh}=1.60-1.90)$, flattened tectiform venter and subangular ventrolateral shoulder; weak ventrolateral nodes. Prongs of external lobe trifid or multiply serrated; altogether 11-24 notches of $\mathrm{E}, \mathrm{A}$ and L lobes.

\section{Material examined}

\section{Holotype}

IRAN - West Azerbaijan, Aras Valley section; Paratirolites Limestone, $2.90 \mathrm{~m}$ below the top; illustrated by Korn et al. (2016: text-fig. 17A); MB.C.25095.

\section{Additional material}

IRAN • 1 specimen; Esfahan Province, Baghuk Mountain E section; Hambast Formation; MB.C.29842.

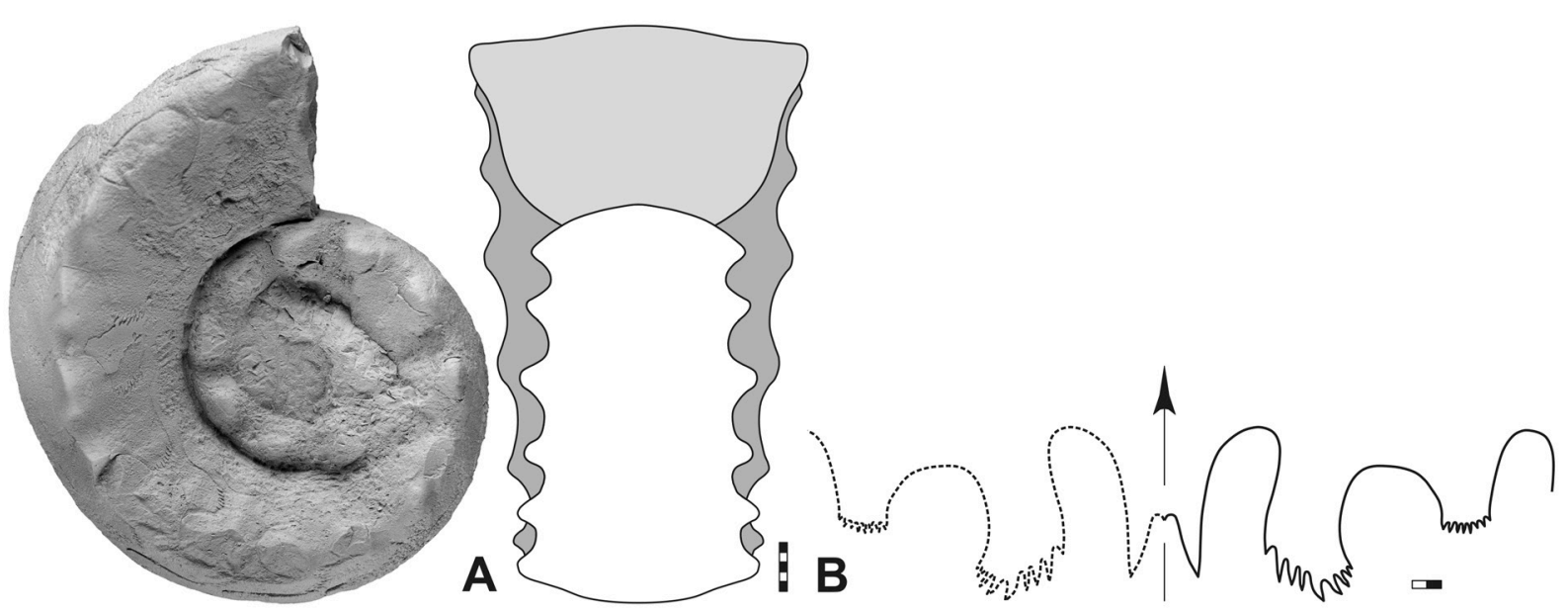

Fig. 31. Paratirolites coronatus Korn \& Ghaderi, 2015. A. Lateral and dorsal view, specimen MB.C.29842, section E, float. B. Suture line, specimen MB.C.29842, at $48.7 \mathrm{~mm} \mathrm{dm,} 17.8 \mathrm{~mm}$ wh. Abbreviations: see Material and methods. Scale bar units $=1 \mathrm{~mm}$. 
Table 14. Conch dimensions (partly estimated) and ratios of Paratirolites coronatus Korn \& Ghaderi in Korn et al. (2016) from Baghuk Mountain.

\begin{tabular}{ccccccccccc}
\hline Specimen & dm & ww & wh & uw & ah & ww/dm & ww/wh & uw/dm & WER & IZR \\
\hline MB.C.29842 & 54.5 & 34.0 & 19.4 & 24.6 & 18.7 & 0.62 & 1.75 & 0.45 & 2.32 & 0.04 \\
MB.C.29842 & 41.2 & 24.0 & 12.7 & 17.9 & - & 0.58 & 1.89 & 0.43 & - & - \\
\hline
\end{tabular}

\section{Description}

Specimen MB.C.29842 is a fully chambered specimen with $55 \mathrm{~mm}$ conch diameter and allows the study of one and a half whorls (Fig. 31A). It has a strongly trapezoidal, depressed whorl profile $(\mathrm{ww} / \mathrm{wh}=1.75)$, weakly sinuous flanks, an angular ventrolateral shoulder and a flattened tectiform venter. Half a volution earlier, the venter is weakly flattened but still rounded and another half volution back, the venter is broadly rounded. The sculpture changes during the last volution of the phragmocone; strong conical nodes at the beginning of this volution are transformed into smaller, longitudinally elongated nodes, which have a position at the ventrolateral shoulder.

The suture line of specimen MB.C.29842 has a V-shaped external lobe with concave flanks and symmetric, narrowly V-shaped simple prongs. The ventrolateral saddle is asymmetric and dorsally inclined and the asymmetric, nearly parallel-sided adventive lobe has nine little notches. The lateral lobe is nearly flat at its base and subdivided in small equally sized notches (Fig. 31B).

\section{Remarks}

Paratirolites coronatus is the paratirolitid with the widest conch, resulting from the coronate ventrolateral shoulder. Therefore, it cannot be confused with any other species. Paratirolites coronatus differs from $P$. vediensis and the other species in the more strongly trapezoidal whorl profile of the adult stage.

\section{Stratigraphic range}

Upper part of the Hambast Formation; precise horizon at Baghuk Mountain not known.

\section{Paratirolites trapezoidalis Shevyrev, 1965}

Fig. 32; Table 15

Paratirolites trapezoidalis Shevyrev, 1965: 177, pl. 24 fig. 1.

Paratirolites trapezoidalis - Shevyrev 1968: 92, pl. 4 fig. 1. - Korn in Ghaderi et al. 2014: text-fig. 7e. — Korn \& Ghaderi in Korn et al. 2016: 858, text-fig. 16.

\section{Diagnosis}

Species of Paratirolites with conch reaching $120 \mathrm{~mm}$ dm. Subadult stage with trapezoidal, depressed whorl profile (ww/wh $=1.40-1.60)$ and flattened, slightly tectiform venter; $10-15$ coarse ribs, which end in coarse conical ventrolateral nodes, per volution. Adult stage with strongly trapezoidal and weakly depressed whorl profile $(\mathrm{ww} / \mathrm{wh}=1.00-1.40)$, flattened venter and angular ventrolateral shoulder; weak straight riblets and numerous small ventrolateral nodes. Prongs of external lobe usually unsubdivided, rarely trifid; altogether 12-19 notches of E, A and L lobes.

\section{Type material}

\section{Holotype}

AZERBAIJAN - Nakhichevan Province, Dorasham 2 section; Paratirolites Limestone; illustrated by Shevyrev (1965: pl. 24 fig. 1); PIN 1252/129. 
Table 15. Conch dimensions (partly estimated) and ratios of selected specimens of Paratirolites trapezoidalis Shevyrev, 1965 from Baghuk Mountain.

\begin{tabular}{ccccccccccc}
\hline Specimen & $\mathbf{d m}$ & ww & wh & uw & ah & ww/dm & ww/wh & uw/dm & WER & IZR \\
\hline MB.C.29845 & 79.0 & 30.6 & 28.1 & 30.5 & 26.0 & 0.39 & 1.09 & 0.39 & 2.22 & 0.07 \\
MB.C.29844 & 71.0 & 26.4 & 25.3 & 29.3 & 23.7 & 0.37 & 1.04 & 0.41 & 2.25 & 0.06 \\
MB.C.29846 & 88.9 & - & 28.5 & 39.3 & 27.2 & - & - & 0.44 & 2.08 & 0.05 \\
\hline
\end{tabular}
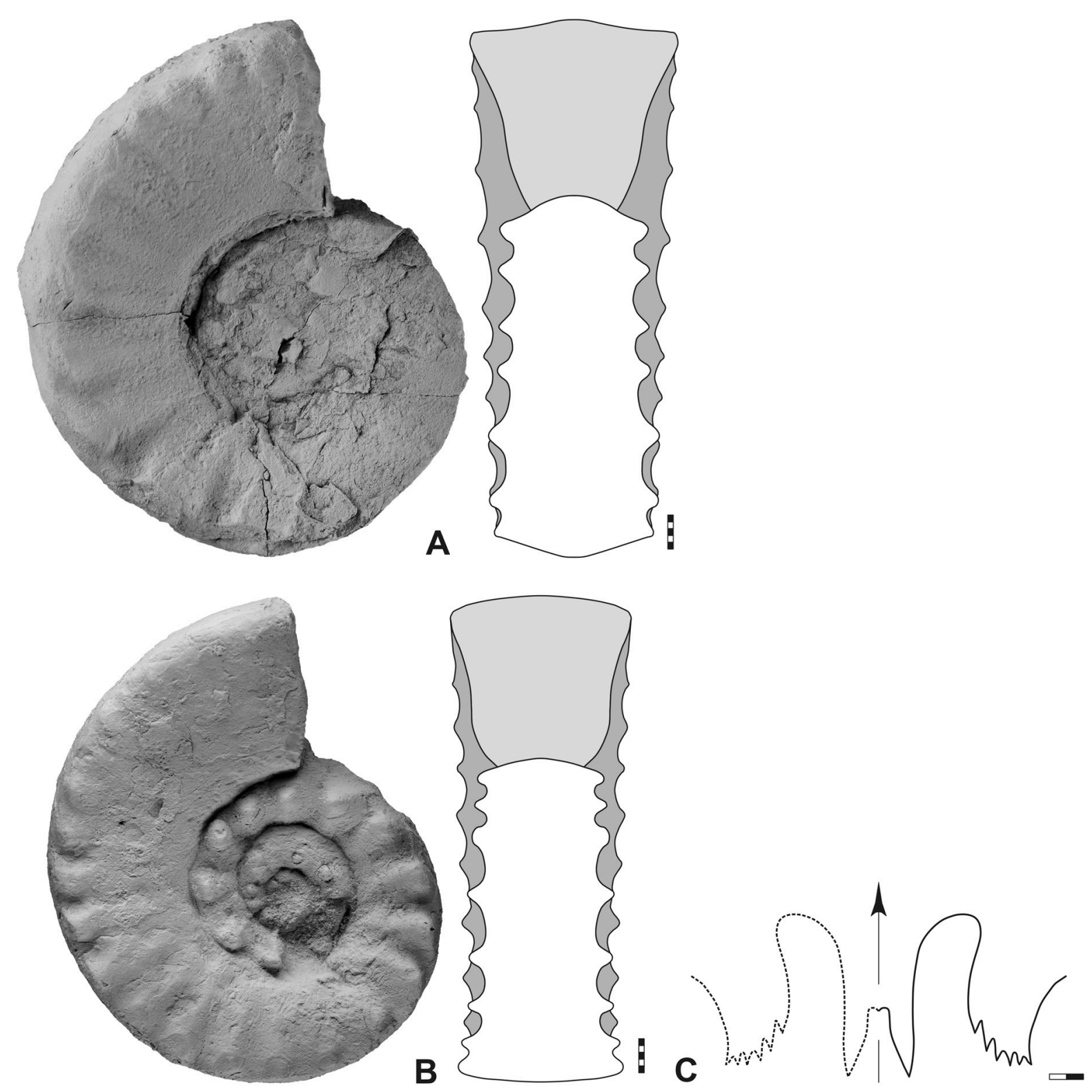

Fig. 32. Paratirolites trapezoidalis Shevyrev, 1965. A-B. Lateral and dorsal views. A. Specimen MB.C.29845, section E, -2.80 m. B. Specimen MB.C.29844, section E, float. C. Suture line of specimen MB.C.29844, at $13.3 \mathrm{~mm}$ wh. Abbreviation: see Material and methods. Scale bar units $=1 \mathrm{~mm}$. 


\section{Material examined}

IRAN • 1 specimen; Esfahan Province, Baghuk Mountain C section; Hambast Formation; MB.C.29843 • 2 specimens; Esfahan Province, Baghuk Mountain E section; Hambast Formation; MB.C.29844 to MB.C.29845 - 3 specimens; Esfahan Province, Baghuk Mountain; Hambast Formation; MB.C.29846 to MB.C.29848.

\section{Description}

Specimen MB.C.29844 is a moderately well-preserved individual of $71 \mathrm{~mm}$ conch diameter and allows the study of one and a half whorls (Fig. 32B). The last segment of 210 degrees belongs to the body chamber, which has a weakly depressed trapezoidal whorl profile $(\mathrm{ww} / \mathrm{wh}=1.05)$ with weakly concave flanks and a nearly flat venter and an angular ventrolateral shoulder. The sculpture of the subadult stage consists of conical and coarse, spiny ventrolateral nodes, 13 on the last phragmocone volution. The nodes become significantly weaker and more numerous on the body chamber, where about 16 of them are present on half a volution.

Specimen MB.C.29844 allows only the study of the suture line on the venter. The external lobe is narrow and parallel-sided with non-serrated, narrow lanceolate prongs. The ventrolateral saddle is very asymmetric and dorsally inclined and the asymmetric adventive lobe has an oblique base that is serrated by six small notches (Fig. 32C). specimen MB.C.29845 (Fig. 32A) is similar in conch shape and sculpture but possesses a suture line with trifid prongs of the external lobe.

\section{Remarks}

Paratirolites vediensis has a similar conch shape, but differs from $P$. trapezoidalis in the stronger ventrolateral nodes in the adult stage. P. coronatus has an even wider whorl profile (ww/wh $=1.60-1.80$ in $P$. coronatus but only 1.40 in P. trapezoidalis); the species has also less coarse but more numerous ventrolateral nodes in the subadult stage (15 in P. coronatus but only 10 in P. trapezoidalis).

\section{Stratigraphic range}

Upper part of the Hambast Formation; 3.05 to $2.80 \mathrm{~m}$ below the extinction horizon (Paratirolites kittli Zone).

Paratirolites baghukensis Korn \& Hairapetian sp. nov. urn:lsid:zoobank.org:act:27027DEB-9F15-4F61-8EA3-3F15E997A1D9

Figs 33-34; Table 16

\section{Diagnosis}

Species of Paratirolites with conch reaching $130 \mathrm{~mm} \mathrm{dm}$. Subadult stage with trapezoidal, weakly depressed whorl profile (ww/wh=1.00-1.20) and rounded venter; about 12 moderately coarse ribs ending in conical ventrolateral nodes per volution. Adult stage with trapezoidal and weakly compressed whorl profile $(\mathrm{ww} / \mathrm{wh}=0.70-0.90)$, flattened tectiform venter and subangular ventrolateral shoulder; numerous sharp ribs ending in sharp radially elongated ventrolateral nodes. Prongs of external lobe usually trifid; altogether 13-15 notches of E, A and L lobes.

\section{Etymology}

Named after the occurrence at Baghuk Mountain.

\section{Material examined}

\section{Holotype}

IRAN - Esfahan Province, Baghuk Mountain G section; Hambast Formation; illustrated in Fig. 33A; MB.C.29868. 


\section{Paratypes}

IRAN • 2 specimens; Esfahan Province, Baghuk Mountain 1 section; Hambast Formation; MB.C.29849 to MB.C.29850 - 4 specimens; Esfahan Province, Baghuk Mountain A section; Hambast Formation; MB.C.29851 to MB.C.29854 - 5 specimens; Esfahan Province, Baghuk Mountain C section; Hambast Formation; MB.C.29855 to MB.C.29859 • 8 specimens; Esfahan Province, Baghuk Mountain E section; Hambast Formation; MB.C.29860 to MB.C.29867 • 7 specimens; Esfahan Province, Baghuk Mountain G section; Hambast Formation; MB.C.29869 to MB.C.29875 • 1 specimen; Esfahan Province, Baghuk Mountain H section; Hambast Formation; MB.C.29876 • 3 specimens; Esfahan Province, Baghuk Mountain; Hambast Formation; MB.C.29877 to MB.C.29879.

\section{Description}

Holotype MB.C.29868 has $70 \mathrm{~mm}$ conch diameter and is fairly well-preserved but slightly corroded. The last third of the terminal volution belongs to the body chamber (which is thus only incompletely preserved); adulthood of the specimen is obvious because of the crowding of the last septa of the phragmocone (Fig. 33A). The penultimate of the preserved whorls shows a trapezoidal profile with a rounded venter. The body chamber finally shows a trapezoidal whorl profile with weakly diverging flanks, an angular ventrolateral shoulder and a nearly flat, tectiform venter. The sculpture changes with the beginning of the terminal body chamber, but this change is continuous without sudden breaks. One subadult volution has ten isolated spiny ventrolateral nodes. Already towards the end of the phragmocone,
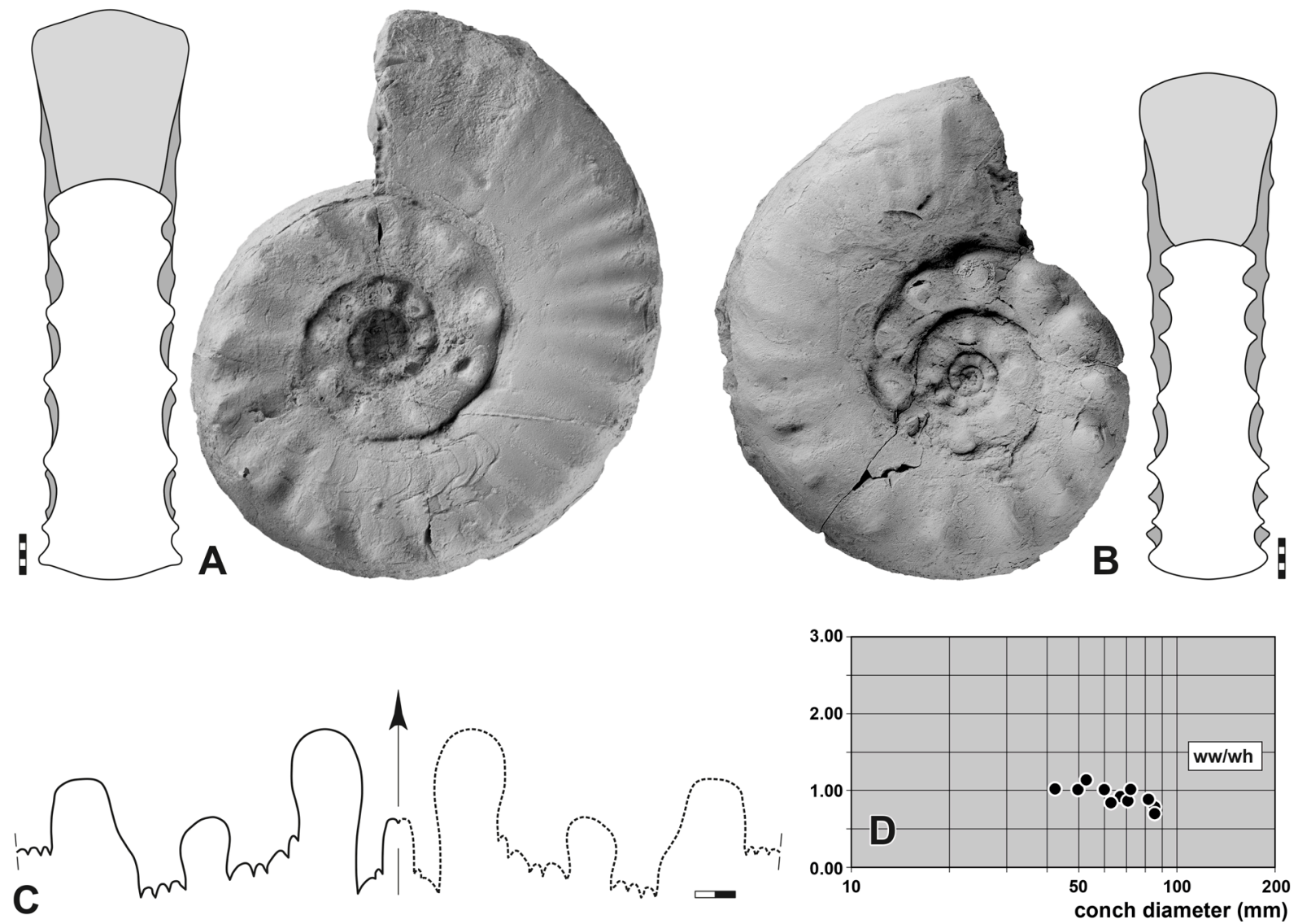

Fig. 33. Paratirolites baghukensis Korn \& Hairapetian sp. nov. A-B. Lateral and dorsal views. A. Holotype MB.C.29868, section G, float. B. Paratype MB.C.29860, section E, -2.55 m. C. Suture line of holotype MB.C.29868, at $49.0 \mathrm{~mm} \mathrm{dm}, 21.0 \mathrm{~mm}$ ww, $16.0 \mathrm{~mm}$ wh. D. Whorl profile proportions. Abbreviations: see Material and methods. Scale bar units $=1 \mathrm{~mm}$. 
these nodes become radially elongate and form coarse ribs across the flank. At the beginning of the terminal body chamber, the ventrolateral nodes weaken and finally, only sharp ribs, about 15 per quarter of a volution, are present.
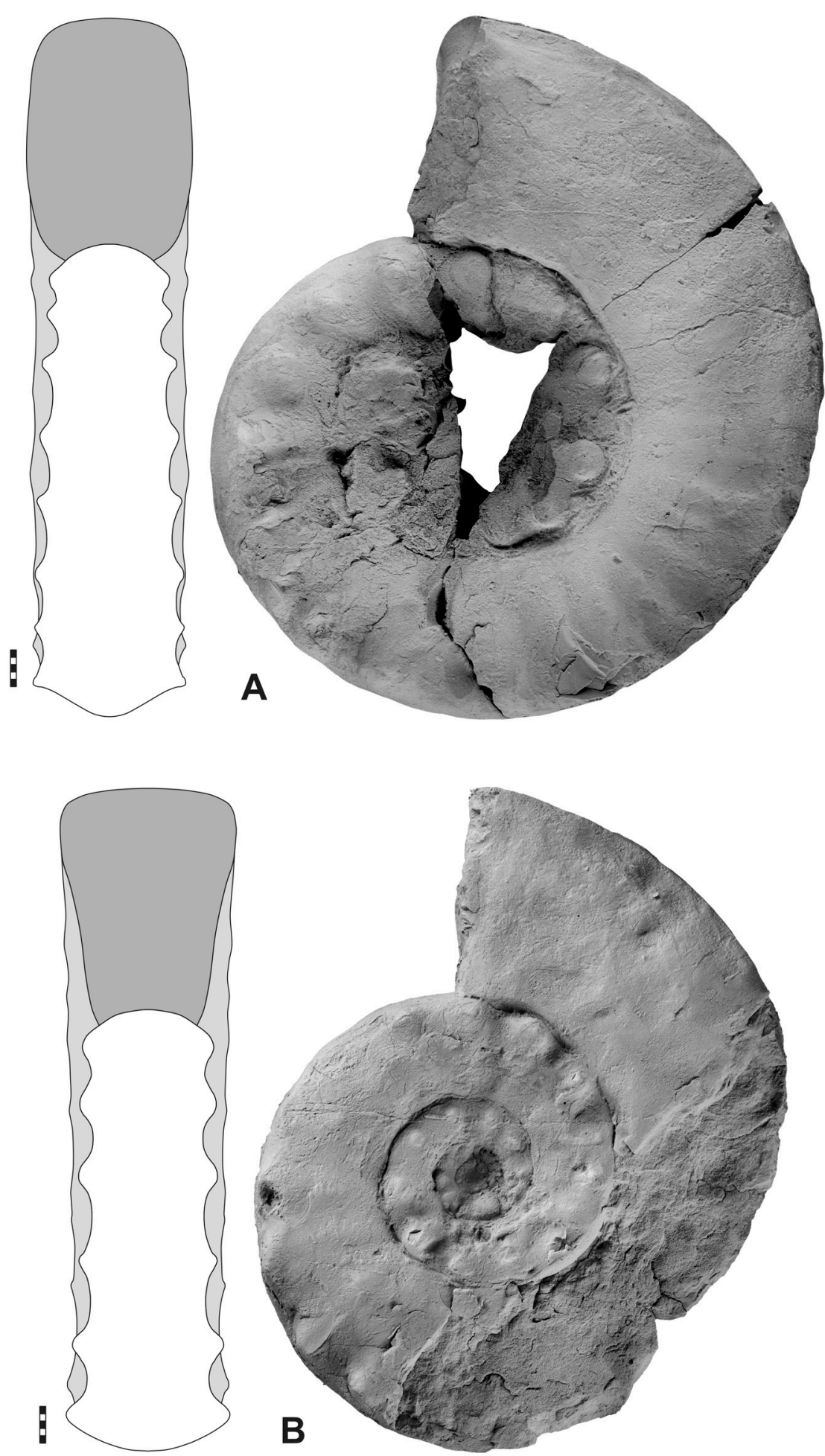

Fig. 34. Paratirolites baghukensis Korn \& Hairapetian sp. nov. A. Paratype MB.C.29850, section 1, -2.70 m. B. Paratype MB.C.29874, section G, float. Scale bar units $=1 \mathrm{~mm}$. 
Table 16. Conch dimensions (partly estimated) and ratios of selected specimens of Paratirolites baghukensis Korn \& Hairapetian sp. nov. from Baghuk Mountain.

\begin{tabular}{ccccccccccc}
\hline Specimen & $\mathbf{d m}$ & $\mathbf{w w}$ & $\mathbf{w h}$ & $\mathbf{u w}$ & $\mathbf{a h}$ & $\mathbf{w w} / \mathbf{d m}$ & $\mathbf{w w} / \mathbf{w h}$ & $\mathbf{u w} / \mathbf{d m}$ & WER & IZR \\
\hline MB.C.29850 & 95.0 & - & 32.5 & 41.5 & 31.6 & - & - & 0.44 & 2.25 & 0.03 \\
MB.C.29874 & 89.1 & - & 28.9 & 36.8 & 27.9 & - & - & 0.41 & 2.12 & 0.03 \\
MB.C.29851 & 71.2 & - & 21.4 & 31.9 & 20.4 & - & - & 0.45 & 1.96 & 0.05 \\
MB.C.29868 & 71.1 & 19.6 & 22.8 & 28.2 & 21.7 & 0.28 & 0.86 & 0.40 & 2.07 & 0.05 \\
MB.C.29860 & 63.1 & 18.1 & 21.6 & 26.4 & 20.0 & 0.29 & 0.84 & 0.42 & 2.14 & 0.07 \\
MB.C.29870 & 94.3 & - & 29.5 & 38.5 & 28.0 & - & - & 0.41 & 2.02 & 0.05 \\
MB.C.29861 & 86.0 & 19.0 & 27.3 & 38.7 & 26.0 & 0.22 & 0.70 & 0.45 & 2.05 & 0.05 \\
MB.C.29862 & 82.3 & 21.0 & 23.8 & 35.4 & 23.0 & 0.26 & 0.88 & 0.43 & 1.93 & 0.03 \\
MB.C.29877 & 60.1 & 18.6 & 18.5 & 26.0 & 17.5 & 0.31 & 1.01 & 0.43 & 1.99 & 0.05 \\
\hline
\end{tabular}

The suture line of holotype MB.C.29868 shows a slightly pouched external lobe with trifid, asymmetric prongs. The ventrolateral saddle is weakly inflated, the adventive and lateral lobes are flattened at the base and subdivided in five and four notches, respectively (Fig. 33C).

Paratype MB.C.29860 (Fig. 33B) is smaller with $61 \mathrm{~mm}$ conch diameter but confirms the description given for the holotype. It shows four whorls preserved and thus allows for the study of the sculpture of the inner volutions.

The two larger paratypes MB.C.29874 and MB.C.29850 (Fig. 34) show then the transformation into the weakly ornamented adult stage, in which a tendency towards a parallel-sided whorl profile is visible.

\section{Remarks}

Paratirolites baghukensis sp. nov. belongs to the slender species of the genus. It differs from the other species of the genus in the sharp ribs on the adult body chamber. Paratirolites multiconus also has a slender conch, but differs from $P$. baghukensis sp. nov. in the much more numerous ventrolateral nodes.

\section{Stratigraphic range}

Upper part of the Hambast Formation; 3.10 to $2.35 \mathrm{~m}$ below the extinction horizon (Paratirolites kittli Zone).

Paratirolites aduncus Korn \& Hairapetian sp. nov. urn:1sid:zoobank.org:act:86D671DC-3110-45AE-A379-2543EA8DEDD0

Figs 35-37; Table 17

\section{Diagnosis}

Species of Paratirolites with conch reaching $125 \mathrm{~mm} \mathrm{dm}$. Subadult stage with circular or weakly depressed whorl profile $(\mathrm{ww} / \mathrm{wh}=1.00-1.30)$ and rounded venter; about 10 very coarse conical ventrolateral nodes per volution. Adult stage with weakly trapezoidal and weakly compressed whorl profile $(\mathrm{ww} / \mathrm{wh}=0.75-0.90)$, flattened tectiform venter and subangular ventrolateral shoulder; about 10 hook-shaped ventrolateral nodes per half volution. Prongs of external lobe usually bifid but rarely trifid or multiply serrated; altogether 11-17 notches of E, A and L lobes. 


\section{Etymology}

From the Latin 'aduncus', meaning 'incurved', because of the curved ventrolateral nodes.

\section{Material examined}

\section{Holotype}

IRAN - Esfahan Province, Baghuk Mountain B section; Hambast Formation; illustrated in Fig. 35A; MB.C.29894.

\section{Paratypes}

IRAN • 9 specimens; Esfahan Province, Baghuk Mountain 1 section; Hambast Formation; MB.C.29880 to MB.C.29888 - 5 specimens; Esfahan Province, Baghuk Mountain A section; Hambast Formation; MB.C.29889 to MB.C.29893 - 1 specimen; Esfahan Province, Baghuk Mountain B section; Hambast Formation; MB.C.29895 - 5 specimens; Esfahan Province, Baghuk Mountain C section; Hambast Formation; MB.C.29896 to MB.C.29900 17 specimens; Esfahan Province, Baghuk Mountain E section; Hambast Formation; MB.C.29901 to MB.C.29917 • 1 specimen; Esfahan Province, Baghuk Mountain F section; Hambast Formation; MB.C.29918 - 8 specimens; Esfahan Province, Baghuk Mountain G section; Hambast Formation; MB.C.29919 to MB.C.29926 • 1 specimen; Esfahan Province, Baghuk Mountain H section; Hambast Formation; MB.C.29927 - 3 specimens; Esfahan Province, Baghuk Mountain; Hambast Formation; MB.C.29928 to MB.C.29930.

\section{Description}

Holotype MB.C.29894 (Fig. 35A) is a fairly well-preserved specimen with $80 \mathrm{~mm}$ conch diameter. It shows, at a conch diameter of $60 \mathrm{~mm}$, three closely approximated septa, after which the terminal body chamber begins with a sudden weakening of the ventrolateral nodes. While these nodes are coarse and conical on the phragmocone, they almost spontaneously become elongated and hook-shaped on the body chamber.

The suture line of holotype MB.C.29894 shows a deep, parallel-sided external lobe with prongs multiply serrated asymmetrically (Fig. 35C). The ventrolateral saddle is nearly symmetric and inverted U-shaped, it is followed by an adventive lobe and a lateral lobe with six little notches each. Both lobes are semicircular at the base and slightly asymmetric.

Paratype MB.C. 29880 has $83 \mathrm{~mm}$ conch diameter; half of the last volution belongs to the body chamber (Fig. 35B). It largely agrees, in conch shape and sculpture, with the holotype. The specimen allows for the study of two whorls, on which transformations in conch shape and sculpture can be observed. The phragmocone has a nearly circular whorl profile (ww/wh about 1.15 at $60 \mathrm{~mm}$ conch diameter) with nine coarse conical ventrolateral nodes on its last volution, which sometimes are developed as sharp spines. On the body chamber, the transformation into a weakly trapezoidal whorl profile can be observed; here the slightly concave flanks diverge towards the subangular ventrolateral shoulder that separates the flank from the flattened, weakly tectiform venter. On the body chamber occurs also a change in the sculpture towards more numerous (about 10 per half whorl) short ribs, which are restricted to the outer flank and ventrally end in hook-shaped, sharp nodes.

Paratype MB.C.29900 is a specimen of $104 \mathrm{~mm}$ conch diameter. It has a fairly well-preserved phragmocone but a weathered body chamber, of which a little more than half a volution is preserved (Fig. 36A). The shape of the body chamber whorl profile had to be reconstructed; it shows a trapezoidal shape with weakly diverging flanks, a rounded ventrolateral shoulder and a flattened tectiform venter. One volution earlier, the whorl profile is strongly trapezoidal with flat, diverging flanks and a flattened, broadly rounded venter. The sculpture is coarse on the phragmocone and weakens in strength significantly on the body chamber. The last volution of the phragmocone has 15 conical, spiny ventrolateral nodes, 

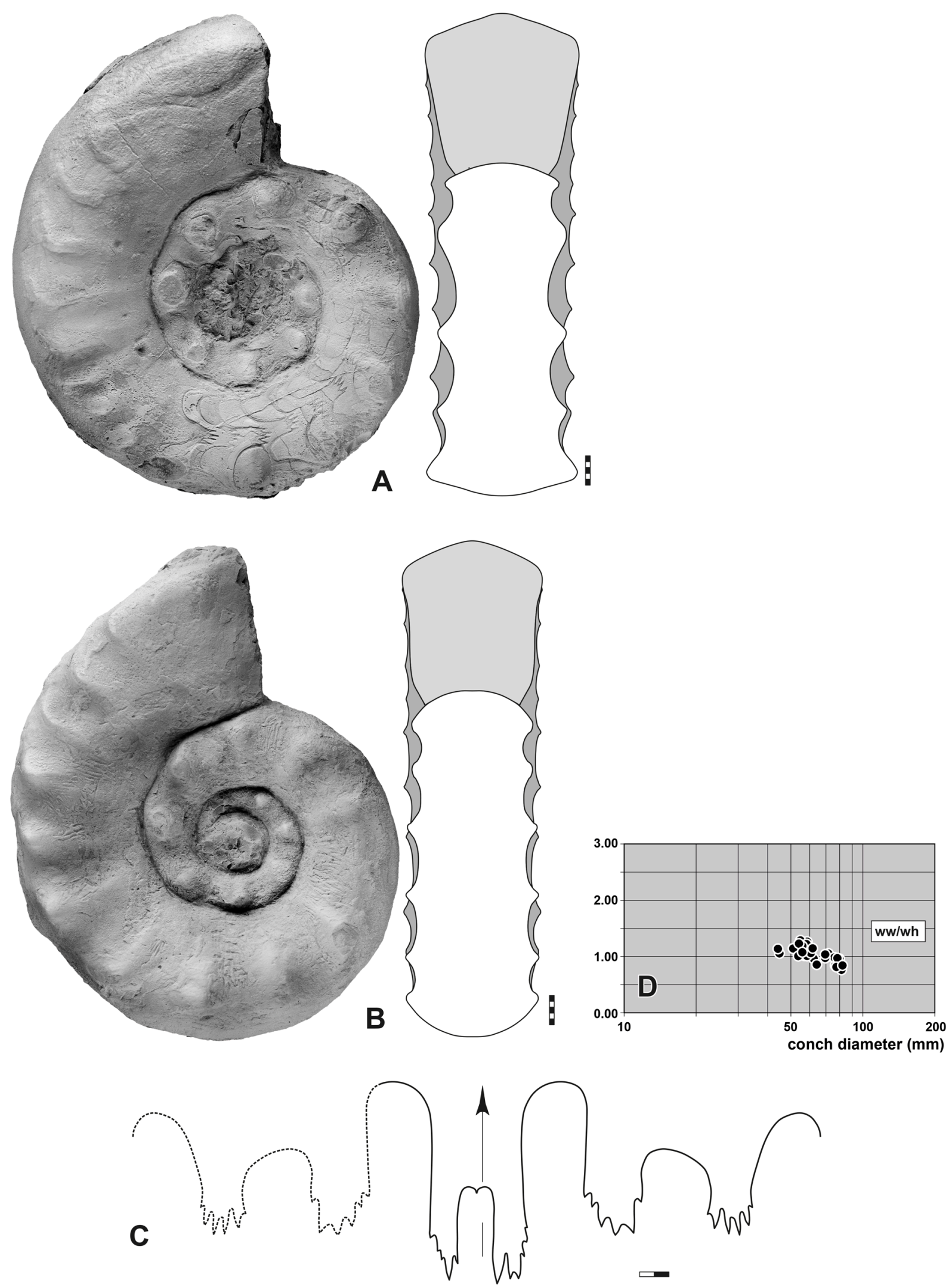


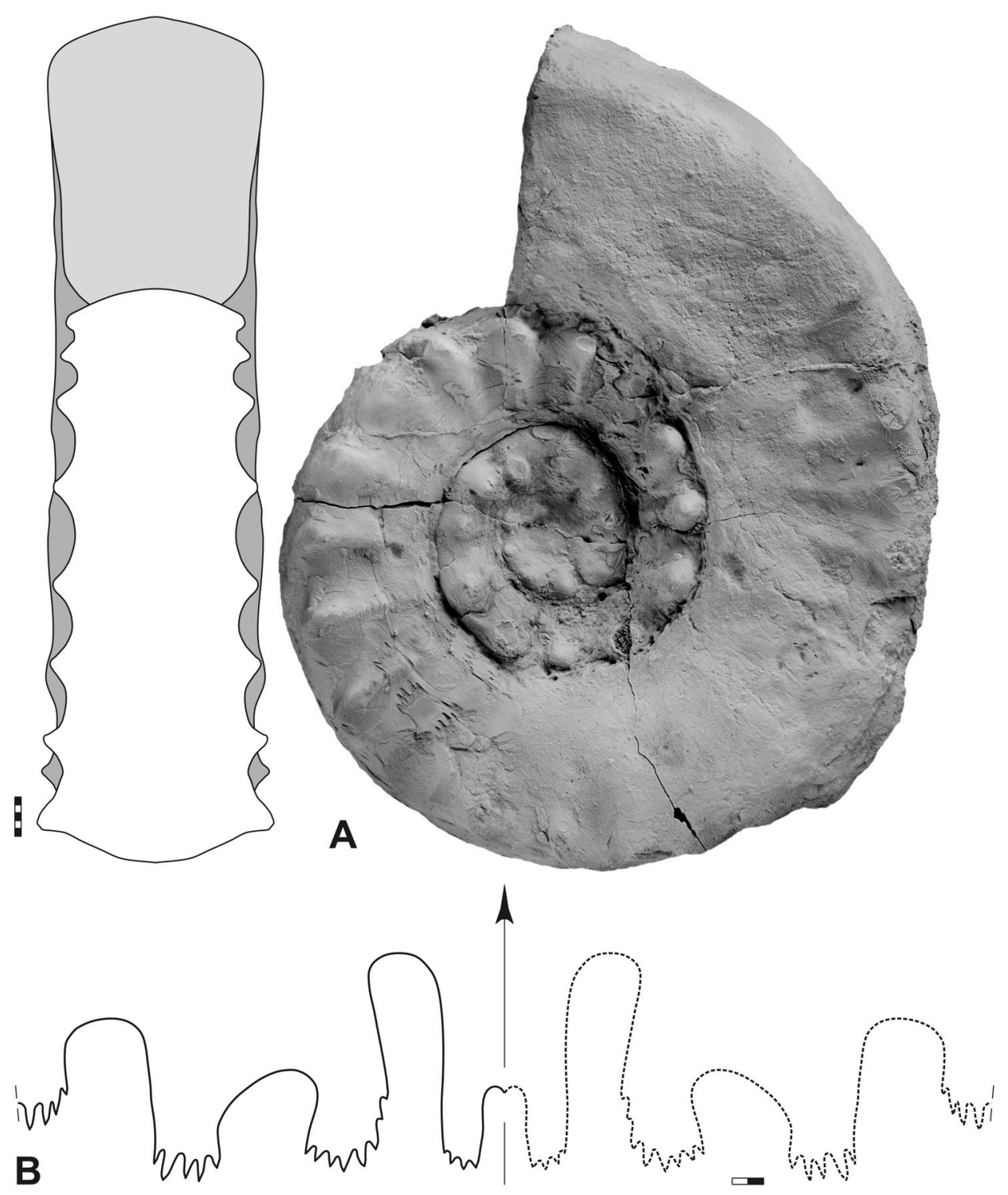

Fig. 36. Paratirolites aduncus Korn \& Hairapetian sp. nov. A. Lateral and dorsal view, paratype MB.C.29900, section C, $-2.45 \mathrm{~m}$. B. Suture line, paratype MB.C. 29900 , at $30 \mathrm{~mm}$ ww, $16.0 \mathrm{~mm}$ wh. Abbreviations: see Material and methods. Scale bar units $=1 \mathrm{~mm}$.

which are first very coarse and conical but later elongate, weaker and more closely spaced. On the body chamber, weak and rounded ribs with concave course are visible on the outer flank.

The suture line of paratype MB.C.29900 shows a parallel-sided external lobe with parallel-sided prongs that are divided by four small notches. The very narrow ventrolateral saddle is weakly inclined towards the umbilicus. Following is a very asymmetric, weakly pouched adventive lobe with eight notches,

Fig. 35 (preceding page). Paratirolites aduncus Korn \& Hairapetian sp. nov. A-B. Lateral and dorsal views. A. Holotype MB.C.29894, section B, float. B. Paratype MB.C.29880, section 1, -1.60 m. C. Suture line of holotype MB.C.29894, at $17.3 \mathrm{~mm}$ wh. D. Whorl profile proportions. Abbreviation: see Material and methods. Scale bar units $=1 \mathrm{~mm}$. 
Table 17. Conch dimensions (partly estimated) and ratios of selected specimens of Paratirolites aduncus Korn \& Hairapetian sp. nov. from Baghuk Mountain.

\begin{tabular}{ccccccccccc}
\hline Specimen & $\mathbf{d m}$ & $\mathbf{w w}$ & $\mathbf{w h}$ & $\mathbf{u w}$ & $\mathbf{a h}$ & $\mathbf{w w} / \mathbf{d m}$ & $\mathbf{w w} / \mathbf{w h}$ & $\mathbf{u w} / \mathbf{d m}$ & $\mathbf{W E R}$ & IZR \\
\hline MB.C.29922 & 81.9 & 22.0 & 28.9 & 34.2 & 26.0 & 0.27 & 0.76 & 0.42 & 2.15 & 0.10 \\
MB.C.29880 & 81.8 & 23.1 & 27.1 & 32.6 & 25.6 & 0.28 & 0.85 & 0.40 & 2.12 & 0.06 \\
MB.C.29894 & 80.3 & 24.9 & 26.1 & 33.9 & 25.1 & 0.31 & 0.95 & 0.42 & 2.12 & 0.04 \\
MB.C.29881 & 77.1 & 21.4 & 25.5 & 33.3 & 24.8 & 0.28 & 0.84 & 0.43 & 2.17 & 0.03 \\
MB.C.29884 & 73.2 & 23.1 & 23.1 & 30.3 & 23.0 & 0.32 & 1.00 & 0.41 & 2.13 & 0.00 \\
MB.C.29901 & 72.2 & 20.4 & 19.5 & 33.3 & 18.8 & 0.28 & 1.05 & 0.46 & 1.83 & 0.04 \\
MB.C.29885 & 62.9 & - & 20.5 & 27.7 & 18.6 & - & - & 0.44 & 2.02 & 0.09 \\
MB.C.29899 & 62.6 & 22.0 & 23.0 & 24.9 & 20.5 & 0.35 & 0.96 & 0.40 & 2.22 & 0.11 \\
MB.C.29924 & 60.9 & 21.0 & 19.9 & 25.9 & 19.4 & 0.34 & 1.06 & 0.43 & 2.15 & 0.03 \\
MB.C.29917 & 82.8 & 22.0 & 26.3 & 31.7 & 25.0 & 0.27 & 0.84 & 0.38 & 2.05 & 0.05 \\
MB.C.29898 & 78.8 & 25.8 & 26.7 & 34.1 & 25.2 & 0.33 & 0.97 & 0.43 & 2.16 & 0.06 \\
MB.C.29903 & 78.0 & 23.0 & 28.4 & 32.2 & 26.4 & 0.29 & 0.81 & 0.41 & 2.29 & 0.07 \\
MB.C.29897 & 76.5 & 24.8 & 25.4 & 30.6 & 24.0 & 0.32 & 0.98 & 0.40 & 2.12 & 0.06 \\
MB.C.29907 & 70.0 & 22.6 & 22.0 & 29.3 & 20.9 & 0.32 & 1.03 & 0.42 & 2.03 & 0.05 \\
MB.C.29912 & 70.0 & 22.3 & 23.0 & 30.2 & 22.0 & 0.32 & 0.97 & 0.43 & 2.13 & 0.04 \\
MB.C.29886 & 70.0 & 23.0 & 22.3 & 29.0 & 21.0 & 0.33 & 1.03 & 0.41 & 2.04 & 0.06 \\
MB.C.29920 & 64.5 & 20.2 & 23.7 & 25.0 & 22.0 & 0.31 & 0.85 & 0.39 & 2.30 & 0.07 \\
MB.C.29921 & 62.0 & 21.6 & 19.0 & 26.0 & 18.0 & 0.35 & 1.14 & 0.42 & 1.99 & 0.05 \\
MB.C.29902 & 54.3 & 22.0 & 18.0 & 25.0 & 17.0 & 0.41 & 1.22 & 0.46 & 2.12 & 0.06 \\
\hline
\end{tabular}
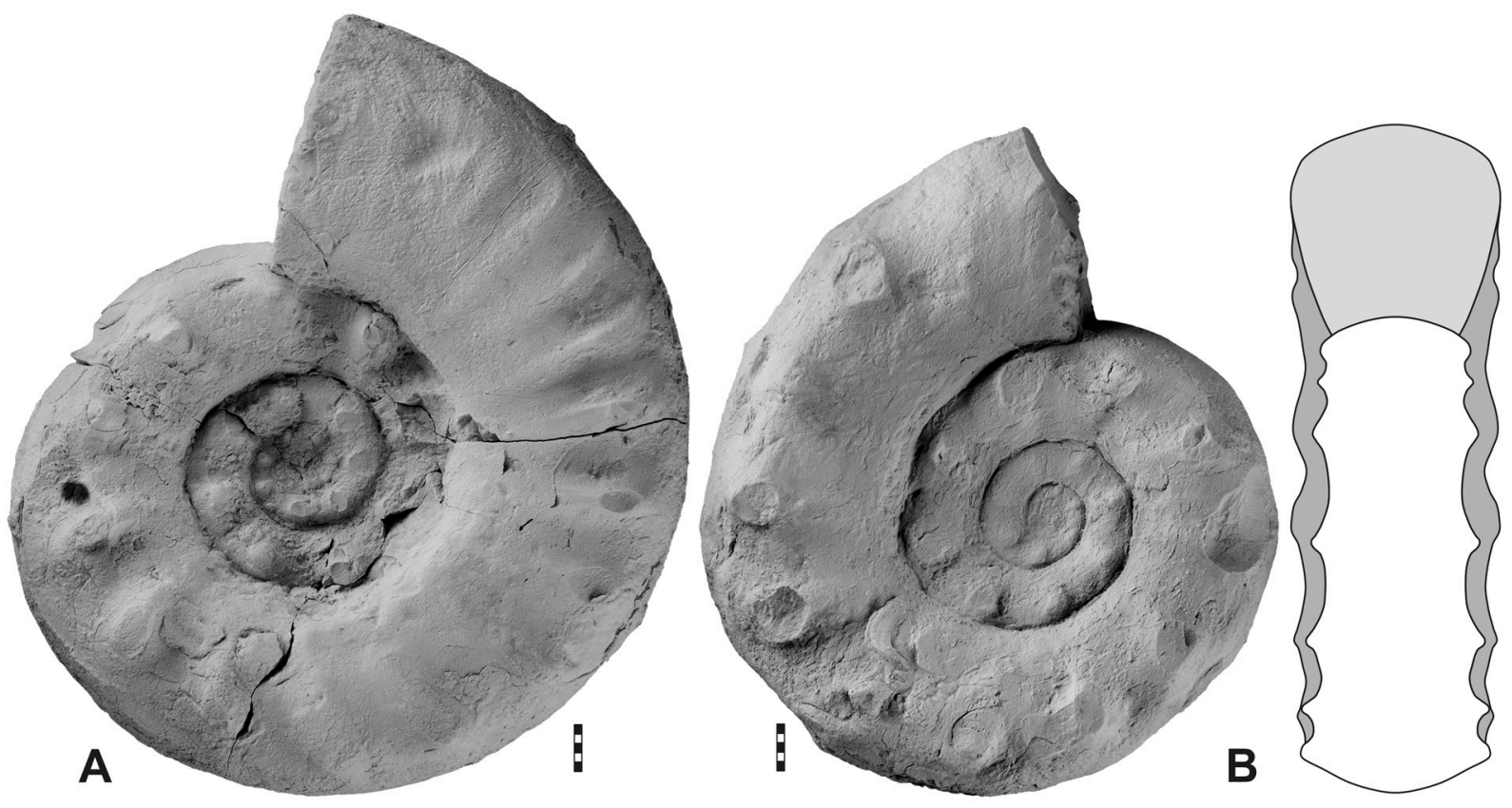

Fig. 37. Paratirolites aduncus Korn \& Hairapetian sp. nov. A. Paratype MB.C.29922, section G, float. B. Paratype MB.C.29884, section 1, float. Scale bar units $=1 \mathrm{~mm}$. 
which are already climbing up the ventral side. The weakly inflated, asymmetric lateral saddle is low and the asymmetric lateral lobe with steep dorsal flank possesses five notches (Fig. 36B).

\section{Remarks}

Paratirolites aduncus sp. nov. differs from the other species of the genus in the presence of the hookshaped ventrolateral nodes of the adult stage.

\section{Stratigraphic range}

Upper part of the Hambast Formation; 2.65 to $1.15 \mathrm{~m}$ below the extinction horizon (Paratirolites kittli Zone to Lutites profundus Zone).

Paratirolites quadratus Korn \& Ghaderi in Korn et al., 2016

Figs 38-39; Table 18

Paratirolites quadratus Korn \& Ghaderi in Korn et al., 2016: 866, text-fig. 25.

\section{Diagnosis}

Paratirolites with conch reaching $90 \mathrm{~mm} \mathrm{dm}$. Subadult stage with trapezoidal, weakly depressed whorl profile (ww/wh $=1.35-1.60)$ and broadly rounded venter; about $11-13$ ribs ending in spiny ventrolateral nodes. Adult stage with weakly trapezoidal to nearly quadrate and weakly depressed whorl profile $(\mathrm{ww} / \mathrm{wh}=1.00-1.20)$, weakly concave venter and angular ventrolateral shoulder; coarse and shallow ribs on flanks. Prongs of external lobe multiply serrated; altogether about 14-17 notches of E, A and L lobes.

\section{Material examined}

Holotype

IRAN 11 specimen; East Azerbaijan, Ali Bashi N section; Paratirolites Limestone, $1.70 \mathrm{~m}$ below the top; illustrated by Korn et al. (2016: text-fig. 25); MB.C.25296.

\section{Additional material}

IRAN • 3 specimens; Esfahan Province, Baghuk Mountain C section; Hambast Formation; MB.C.29331 to MB.C.29333.

\section{Description}

Specimen MB.C.29932 is a nicely preserved specimen of $72 \mathrm{~mm}$ conch diameter (Fig. 38A). It shows weak septal crowding at $48 \mathrm{~mm}$ diameter and thus half of the last volution belongs to the body chamber. The whorl profile shape changes from trapezoidal with convex flanks of the subadult stage to parallelsided at the beginning of the body chamber; at the same time the shape of the venter changes from weakly convex to nearly totally flattened. The sculpture of the subadult stage possesses 13 conical ventrolateral nods per volution; they originate from rounded radial ribs. On the body chamber the nodes are weaker and become radially elongated, they are connected with low, rounded dorsolateral ribs.

The suture line of specimen MB.C.29932 shows an asymmetric external lobe with weakly concave flanks, of which both prongs are trifid. Also on the venter follows the very narrow, weakly inflated ventrolateral saddle and the asymmetric adventive lobe (Fig. 38B).

Specimen MB.C.29933 is a larger specimen with $101 \mathrm{~mm}$ conch diameter (Fig. 39A). It shows similar conch and sculpture characteristics but differs from the preceding specimen in the coarser ventrolateral nods and the larger phragmocone $(62 \mathrm{~mm} \mathrm{dm})$. Its suture line has a parallel-sided external lobe with 
Table 18. Conch dimensions (partly estimated) and ratios of selected specimens of Paratirolites quadratus Korn \& Ghaderi in Korn et al. (2016) from Baghuk Mountain.

\begin{tabular}{ccccccccccc}
\hline Specimen & dm & ww & wh & uw & ah & ww/dm & ww/wh & uw/dm & WER & IZR \\
\hline MB.C.29933 & 101.0 & 26.8 & 32.6 & 43.3 & 31.5 & 0.27 & 0.82 & 0.43 & 2.11 & 0.03 \\
MB.C.29933 & 70.4 & 28.5 & 24.4 & 28.2 & - & 0.40 & 1.17 & 0.40 & - & - \\
MB.C.29932 & 71.5 & 23.6 & 25.4 & 30.4 & 23.9 & 0.33 & 0.93 & 0.43 & 2.26 & 0.06 \\
MB.C.29932 & 47.9 & 26.3 & 15.7 & 20.5 & - & 0.55 & 1.68 & 0.43 & - & - \\
MB.C.29931 & 61.1 & 21.5 & 19.6 & 26.4 & 18.4 & 0.35 & 1.10 & 0.43 & 2.05 & 0.06 \\
\hline
\end{tabular}

parallel-sided trifid prongs. The ventrolateral saddle is very narrow and the adventive lobe shows strong serration by small notches, which climb up the ventral flank to more than half of the lobe depth. The lateral saddle is weakly inflated and lower than the ventrolateral saddle and the lateral lobe is nearly parallel-sided and possesses five small notches (Fig. 39B).

\section{Remarks}

Paratirolites quadratus differs from the other species of Paratirolites in the slightly trapezoidal, nearly quadrate whorl profile in the adult conch and the very long, spiny ventrolateral nodes.
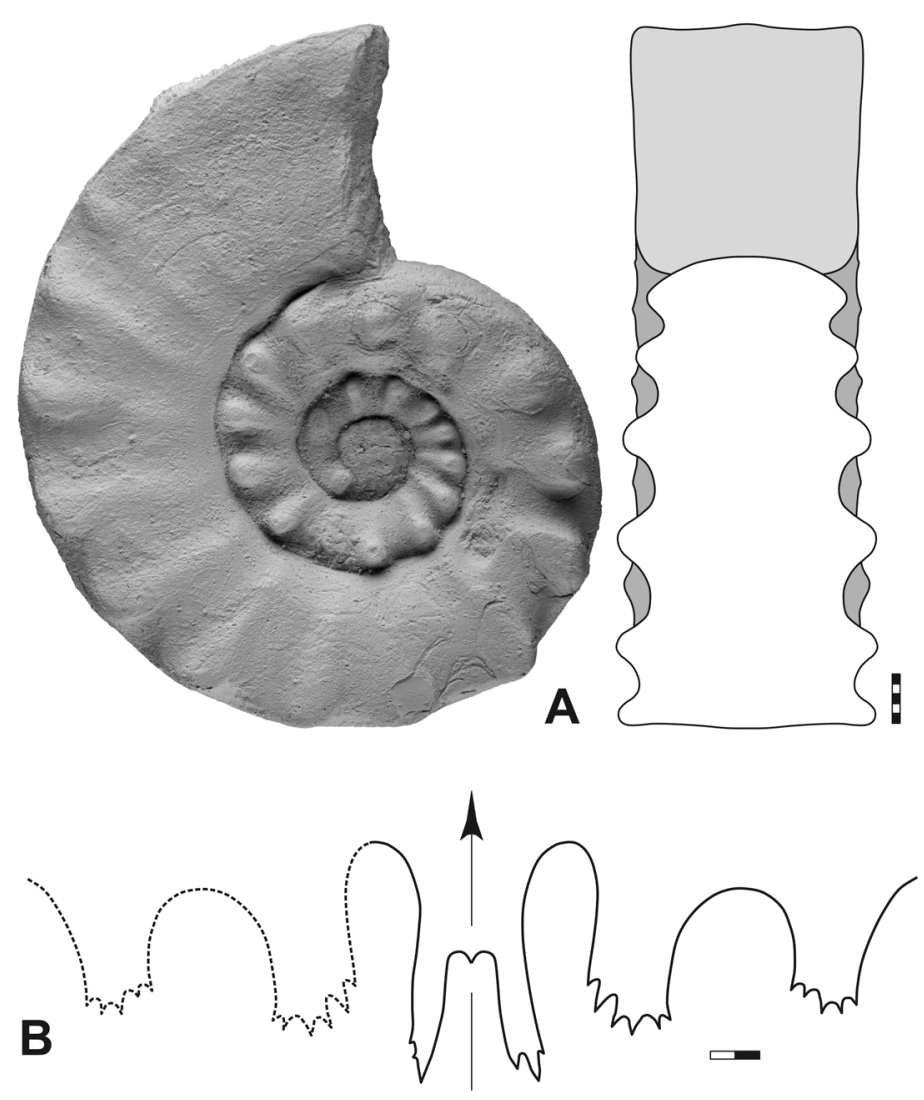

Fig. 38. Paratirolites quadratus Korn \& Ghaderi, 2016. A. Lateral and dorsal view, specimen MB.C.29932, section E, float. B. Suture line, specimen MB.C.29932, at $13.5 \mathrm{~mm}$ wh. Abbreviation: see Material and methods. Scale bar units $=1 \mathrm{~mm}$. 


\section{Stratigraphic range}

At Baghuk Mountain only known from float from the upper part of the Hambast Formation; Stoyanowites dieneri Zone in the Julfa region.

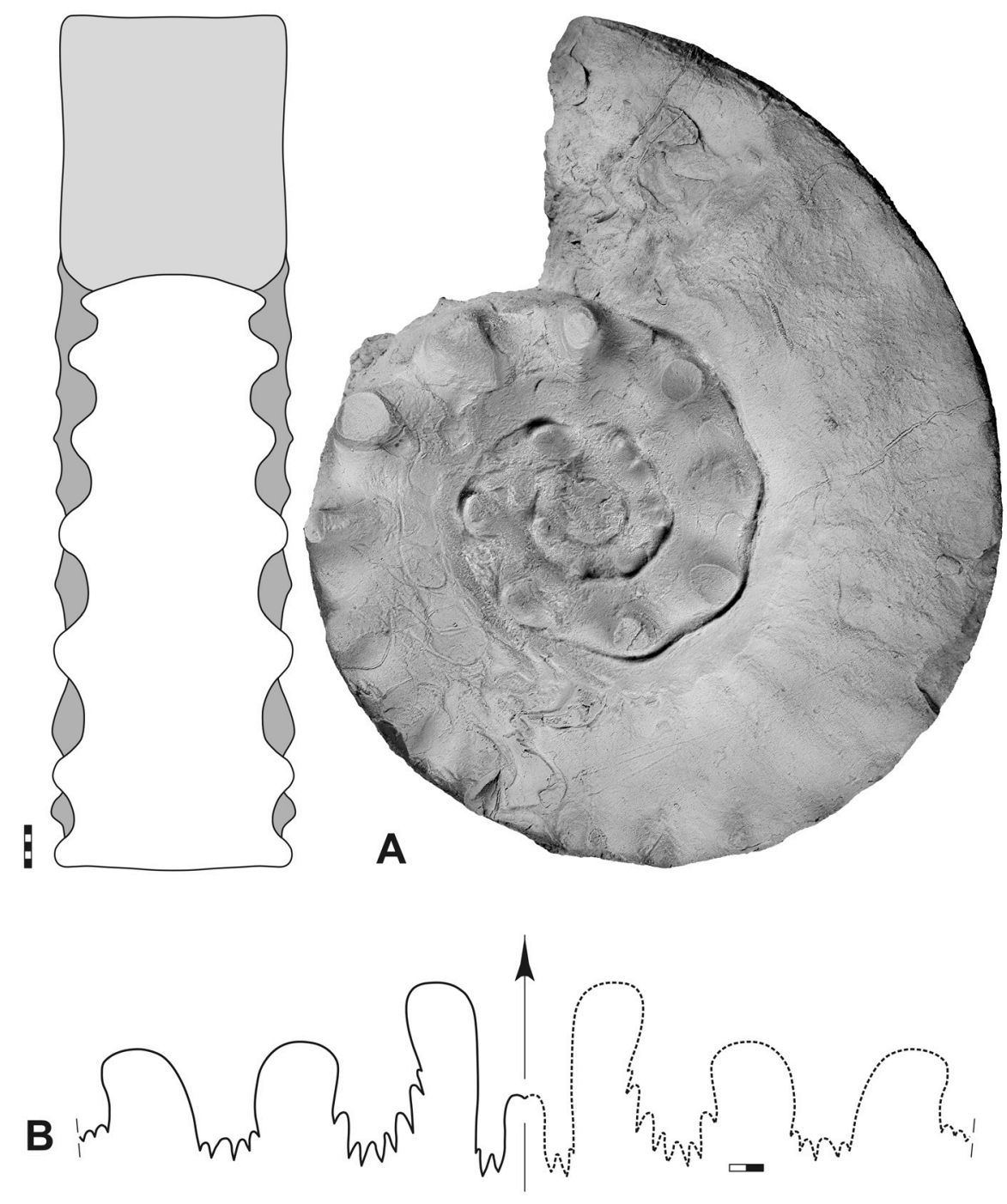

Fig. 39. Paratirolites quadratus Korn \& Ghaderi, 2016. A. Lateral and dorsal view, specimen MB.C.29933, section E, float. B. Suture line, specimen MB.C.29933, at $29.0 \mathrm{~mm} w w, 17.0 \mathrm{~mm}$ wh. Abbreviations: see Material and methods. Scale bar units $=1 \mathrm{~mm}$.

Paratirolites serus Korn \& Ghaderi in Korn et al., 2016

Fig. 40; Table 19

Paratirolites serus Korn \& Ghaderi in Korn et al., 2016: 868, text-fig. 27.

\section{Diagnosis}

Paratirolites with conch reaching $80 \mathrm{~mm} \mathrm{dm}$. Subadult stage with weakly to strongly trapezoidal, depressed whorl profile $(\mathrm{ww} / \mathrm{wh}=1.40-1.80)$ and broadly rounded venter; $12-14$ coarse conical ventrolateral nodes. Adult stage with circular or slightly trapezoidal, weakly to moderately depressed 
whorl profile $(\mathrm{ww} / \mathrm{wh}=1.20-1.60)$, flattened venter and subangular to angular ventrolateral shoulder; numerous ribs on the flank. Prongs of external lobe simple; altogether 6-9 notches of E, A and L lobes.

\section{Material examined}

\section{Holotype}

IRAN • East Azerbaijan, Ali Bashi N section; Paratirolites Limestone, $0.65 \mathrm{~m}$ below the top; illustrated by Korn \& Ghaderi in Korn et al. (2016: text-fig. 27a); MB.C.25300.

\section{Additional material}

IRAN • 1 specimen; Esfahan Province, Baghuk Mountain C section; Hambast Formation; MB.C.29934 • 2 specimens; Esfahan Province, Baghuk Mountain E section; Hambast Formation; MB.C.29935 to MB.C.29936 - 1 specimen; Esfahan Province, Baghuk Mountain F section; Hambast Formation; MB.C.29937.

\section{Description}

Specimen MB.C.29936 has $62 \mathrm{~mm}$ conch diameter and is the largest available specimen (Fig. 40A). It is corroded but still rather well preserved and allows the study of three whorls. A little more than half a volution belongs to the body chamber. The weakly depressed whorl profile $(\mathrm{ww} / \mathrm{wh}=1.05)$ of the body

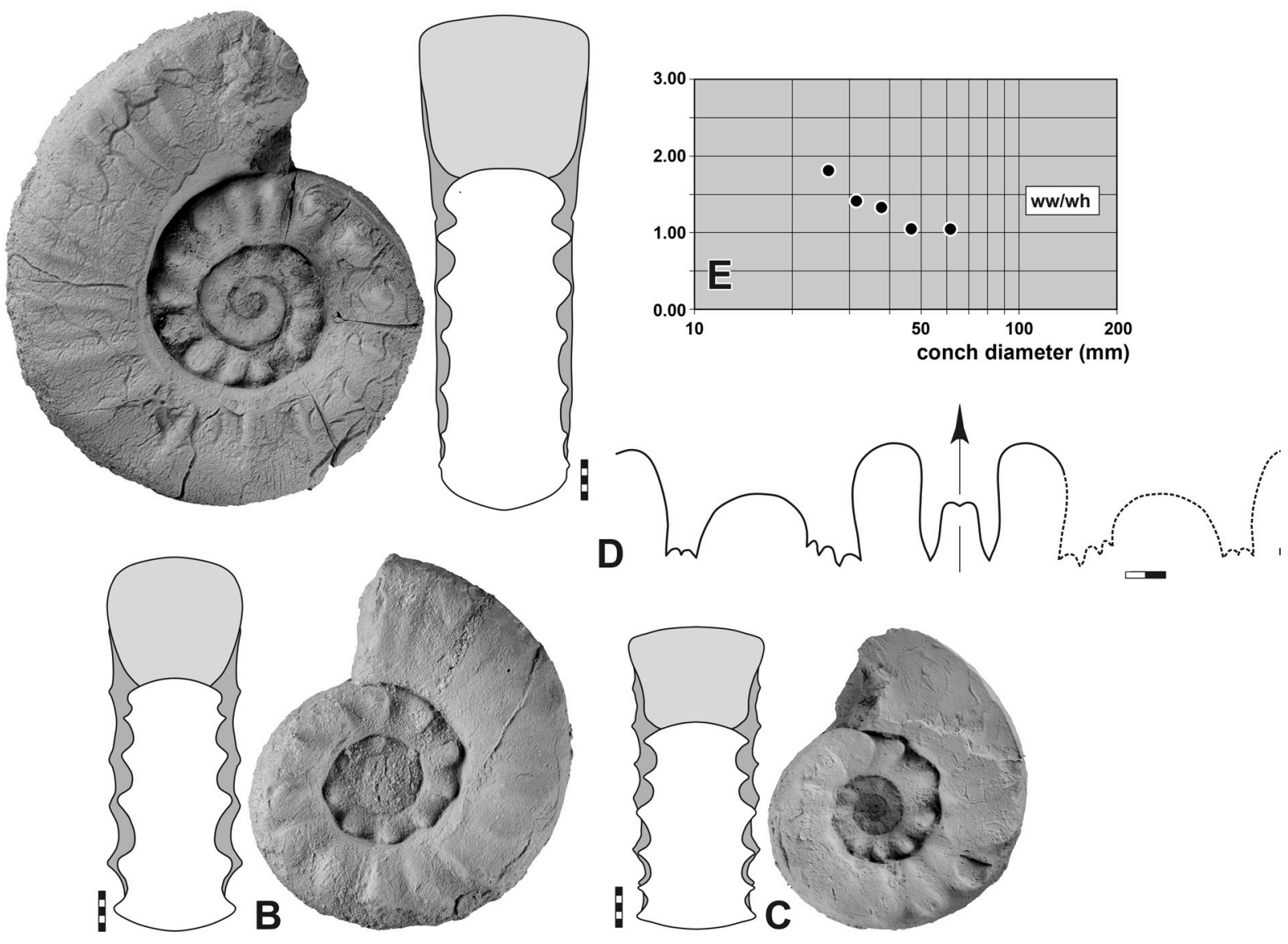

Fig. 40. Paratirolites serus Korn \& Ghaderi, 2016. A. Lateral and dorsal view, specimen MB.C.29936, section E, float. B. Lateral and dorsal view, specimen MB.C.29934, section C, -0.60 m. C. Lateral and dorsal view, specimen MB.C.29937, section F, -0.75 m. D. Suture line, specimen MB.C.29934, at $16.0 \mathrm{~mm}$ ww, $10.3 \mathrm{~mm}$ wh. E. Whorl profile proportions. Abbreviations: see Material and methods. Scale bar units $=1 \mathrm{~mm}$. 
Table 19. Conch dimensions (partly estimated) and ratios of selected specimens of Paratirolites serus Korn \& Ghaderi in Korn et al. (2016) from Baghuk Mountain.

\begin{tabular}{ccccccccccc}
\hline Specimen & $\mathbf{d m}$ & $\mathbf{w w}$ & $\mathbf{w h}$ & $\mathbf{u w}$ & $\mathbf{a h}$ & $\mathbf{w w} / \mathbf{d m}$ & ww/wh & uw/dm & WER & IZR \\
\hline MB.C.29936 & 61.8 & 21.3 & 20.5 & 26.2 & 19.7 & 0.34 & 1.04 & 0.42 & 2.15 & 0.04 \\
MB.C.29934 & 46.7 & 16.9 & 16.2 & 20.2 & 15.2 & 0.36 & 1.04 & 0.43 & 2.20 & 0.06 \\
MB.C.29937 & 37.8 & 16.9 & 12.8 & 15.7 & 12.0 & 0.45 & 1.32 & 0.42 & 2.15 & 0.06 \\
MB.C.29935 & 36.7 & 14.7 & 13.6 & 15.0 & 12.7 & 0.40 & 1.08 & 0.41 & 2.34 & 0.07 \\
\hline
\end{tabular}

chamber is trapezoidal with weakly diverging flanks and the flattened venter is separated from the flanks by a subangular ventrolateral shoulder. The sculpture changes, on the last portion of the phragmocone, from a subadult stage with 14 coarse ventrolateral nodes per volution to the adult stage with numerous weak radial ribs with weak ventrolateral nodes on the flank.

Specimen MB.C.29934 is a smaller individual with $48 \mathrm{~mm}$ conch diameter and is better preserved than the preceding one with half a volution of the body chamber preserved (Fig. 40B). It shows a weakly trapezoidal, weakly depressed body chamber whorl profile $(\mathrm{ww} / \mathrm{wh}=1.05)$ with rounded ventrolateral shoulder and a broadly rounded venter, while the phragmocone has a more depressed whorl profile (ww/ $w h=1.40)$. The sculpture in the subadult stage has twelve coarse ventrolateral nodes, which become weaker and radially elongated on the body chamber, where they finally disappear and instead shallow radial dorsolateral ribs take place.

The suture line of specimen MB.C.29934 has an external lobe with nearly parallel flanks and unserrated, narrow lanceolate prongs. The ventrolateral saddle is weakly asymmetric and the adventive lobe is strongly asymmetric with a steep ventral flank, four little notches and an oblique dorsal side. The lateral lobe possesses only three small notches (Fig. 40D).

\section{Remarks}

Paratirolites serus is the stratigraphically youngest species of the genus in the Baghuk Mountain sections. It differs from the other by its small conch size and the simple suture line with unsubdivided prongs of the external lobe.

Subadult specimens of $P$. serus resemble some stratigraphically older species such as $P$. kittli and particularly $P$. vediensis. Paratirolites serus differs from these in the smaller conch diameter $(40 \mathrm{~mm}$ maximum phragmocone diameter in contrast to $70-80 \mathrm{~mm}$ in $P$. kittli and $P$. vediensis) and a simpler suture line with unsubdivided prongs of the external lobe.

\section{Stratigraphic range}

Upper part of the Hambast Formation; 0.75 to $0.60 \mathrm{~m}$ below the extinction horizon (Abichites stoyanowi Zone).

Genus Clivotirolites Korn \& Hairapetian gen. nov. urn:1sid:zoobank.org:act:2F50EBFF-9384-40A5-84D9-573E68455DD2

\section{Type species}

Clivotirolites decoratus Korn \& Hairapetian gen. et sp. nov., Baghuk Mountain. 


\section{Diagnosis}

Representatives of the family Dzhulfitidae with large conch; maximum adult diameters are about $120 \mathrm{~mm}$. Adult stage with trapezoidal whorl profile. Subadult stage with conical ventrolateral nodes, adult stage with weak ribs. Suture line protracted on the flanks, with deep external lobe; depths of external lobe and adventive lobe nearly identical.

\section{Etymology}

From the Latin 'clivus', meaning 'oblique', because of the suture line and the similarity with Tirolites and Paratirolites.

\section{Included species}

Clivotirolites decoratus Korn \& Hairapetian gen. et sp. nov.; Clivotirolites petilus Korn \& Hairapetian gen. et sp. nov.

\section{Remarks}

Clivotirolites gen. nov. differs from Paratirolites and related genera in the oblique protracting outline of the outer suture line.

Clivotirolites decoratus Korn \& Hairapetian gen. et sp. nov. urn:1sid:zoobank.org:act:0A7C7606-6D92-4630-BAF3-1A8E30B6486D

Figs 41-43; Table 20

\section{Diagnosis}

Species of Clivotirolites gen. nov. with conch reaching $110 \mathrm{~mm} \mathrm{dm}$. Subadult stage with trapezoidal, weakly depressed whorl profile (ww/wh $=1.10-1.20)$ and slightly flattened venter; about 20-24 weak ventrolateral spines per volution. Adult stage with parallel or weakly diverging flanks and weakly compressed whorl profile $(\mathrm{ww} / \mathrm{wh}=0.70-0.80)$, flattened, slightly tectiform venter and angular ventrolateral shoulder; numerous rounded ribs on flank ending in sharp ventrolateral nodes. Prongs of external lobe variable, simple to digitate; altogether 10-17 notches of E, A and L lobes.

\section{Etymology}

From the Latin 'decoratus', meaning 'decorated', because of the sculpture.

\section{Material examined}

\section{Holotype}

IRAN - Esfahan Province, Baghuk Mountain C section; Hambast Formation, $1.35 \mathrm{~m}$ below the top; illustrated in Fig. 41A; MB.C.29941.

\section{Paratypes}

IRAN • 1 specimen; Esfahan Province, Baghuk Mountain 1 section; Hambast Formation; MB.C.29938 • 2 specimens; Esfahan Province, Baghuk Mountain B section; Hambast Formation; MB.C.29939 to MB.C.29940 - 14 specimens; Esfahan Province, Baghuk Mountain E section; Hambast Formation; MB.C.29942 to MB.C.29955 - 2 specimens; Esfahan Province, Baghuk Mountain F section; Hambast Formation; MB.C.29956 to MB.C.29957 • 2 specimens; Esfahan Province, Baghuk Mountain G section; Hambast Formation; MB.C.29958 to MB.C.29959 • 2 specimens; Esfahan Province, Baghuk Mountain H section; Hambast Formation; MB.C.29960 to MB.C.29961. 


\section{Description}

Holotype MB.C.29941 is a rather well-preserved specimen of $64 \mathrm{~mm}$ conch diameter and shows all typical characters for the species (Fig. 41A). The specimen shows one and a half whorls preserved. It displays septal crowding and the end of the phragmocone appears at $38 \mathrm{~mm}$ diameter. About 210 degrees of the last volution belong to the body chamber, which shows a weakly trapezoidal whorl profile with weakly concave, weakly diverging flanks, a subangular ventrolateral shoulder and a flattened tectiform venter. The whorl belonging to the phragmocone has a more pronounced trapezoidal profile with convex, diverging flanks. The sculpture on the phragmocone part consists of rather small, pointed ventrolateral tubercles, 22 per volution. On the body chamber, these tubercles are connected with weak and rounded radial ribs, which are strongest on the inner flank.

Paratype MB.C.29946 is a similar specimen with $58 \mathrm{~mm}$ conch diameter and the last septum at $33 \mathrm{~mm}$ dm (Fig. 41B). It possesses a nearly quadrate whorl cross section of the body chamber but also shows that the profile is trapezoidal in an earlier growth stage. On the last volution of the phragmocone, 20 sharp ventrolateral nodes can be counted.

Larger paratypes such as MB.C.29947 (50 mm phragmocone diameter), MB.C.29944 (52 mm; Fig. 42B), MB.C.29938 (52 mm; Fig. 42A) and MB.C.29958 (53 mm; Fig. 43A) are generally similar but show stronger diverging flanks of the body chamber.

Suture lines were drawn from four specimens, all of them show principally similar outlines with some common characters (Fig. 43B-E). The external lobe is not as deep as the adventive lobe, it is wider at its base, from where the flanks converge towards the ventrolateral saddle. All four specimens show asymmetric notching of its prongs; usually there are three notches but also more intense serration is possible. The ventrolateral saddle is usually slightly inflated and the adventive lobe is parallel-sided with five or six notches at its base.

\section{Remarks}

Clivotirolites decoratus gen. et sp. nov. differs in the large number (more than 20 per volution) of ventrolateral nodes from the species of Clivotirolites petilus gen. et sp. nov. (about 15 nodes per volution).
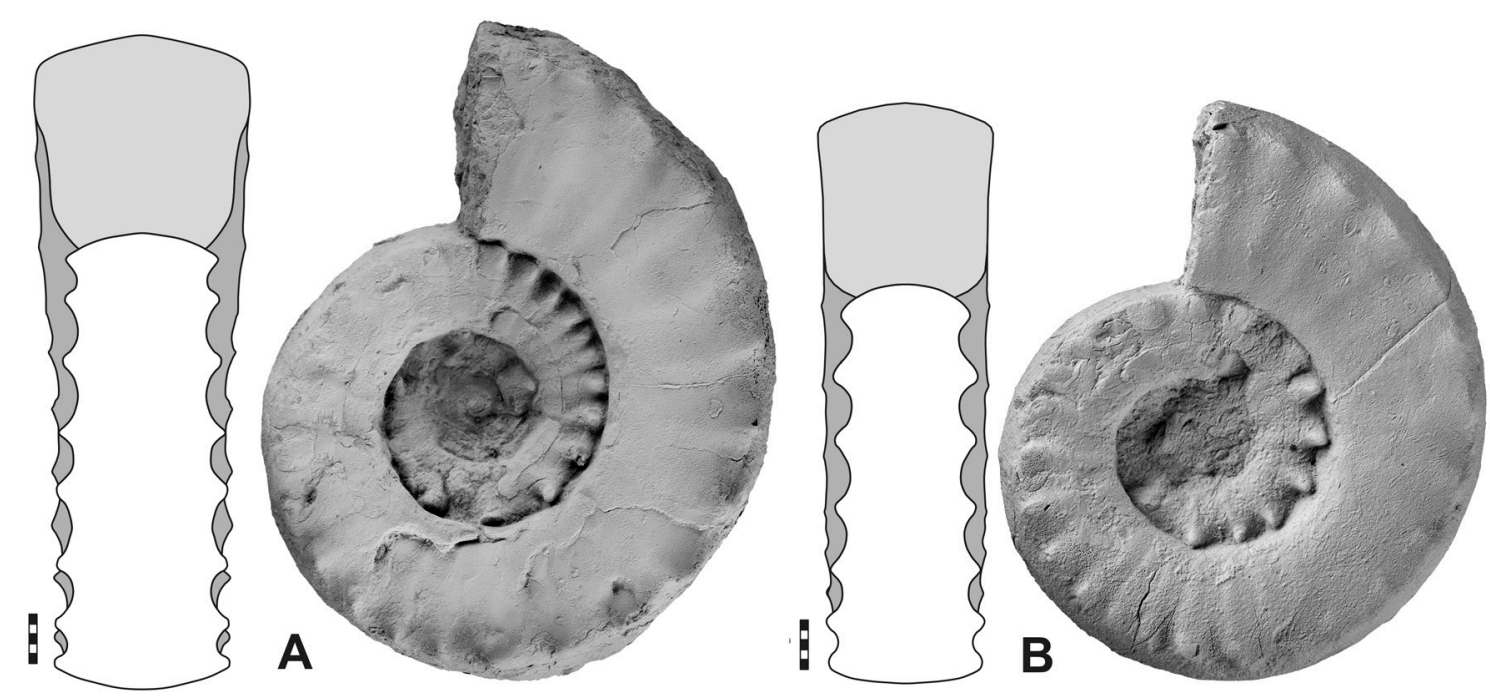

Fig. 41. Clivotirolites decoratus Korn \& Hairapetian gen. et sp. nov., lateral and dorsal views. A. Holotype MB.C.29941, section C, -1.35 m. B. Paratype MB.C.29946, section E, float. Scale bar units $=1 \mathrm{~mm}$. 


\section{Stratigraphic range}

Upper part of the Hambast Formation; 2.05 to $1.10 \mathrm{~m}$ below the extinction horizon (Alinashites ferdowsii Zone to Abichites abichi Zone).
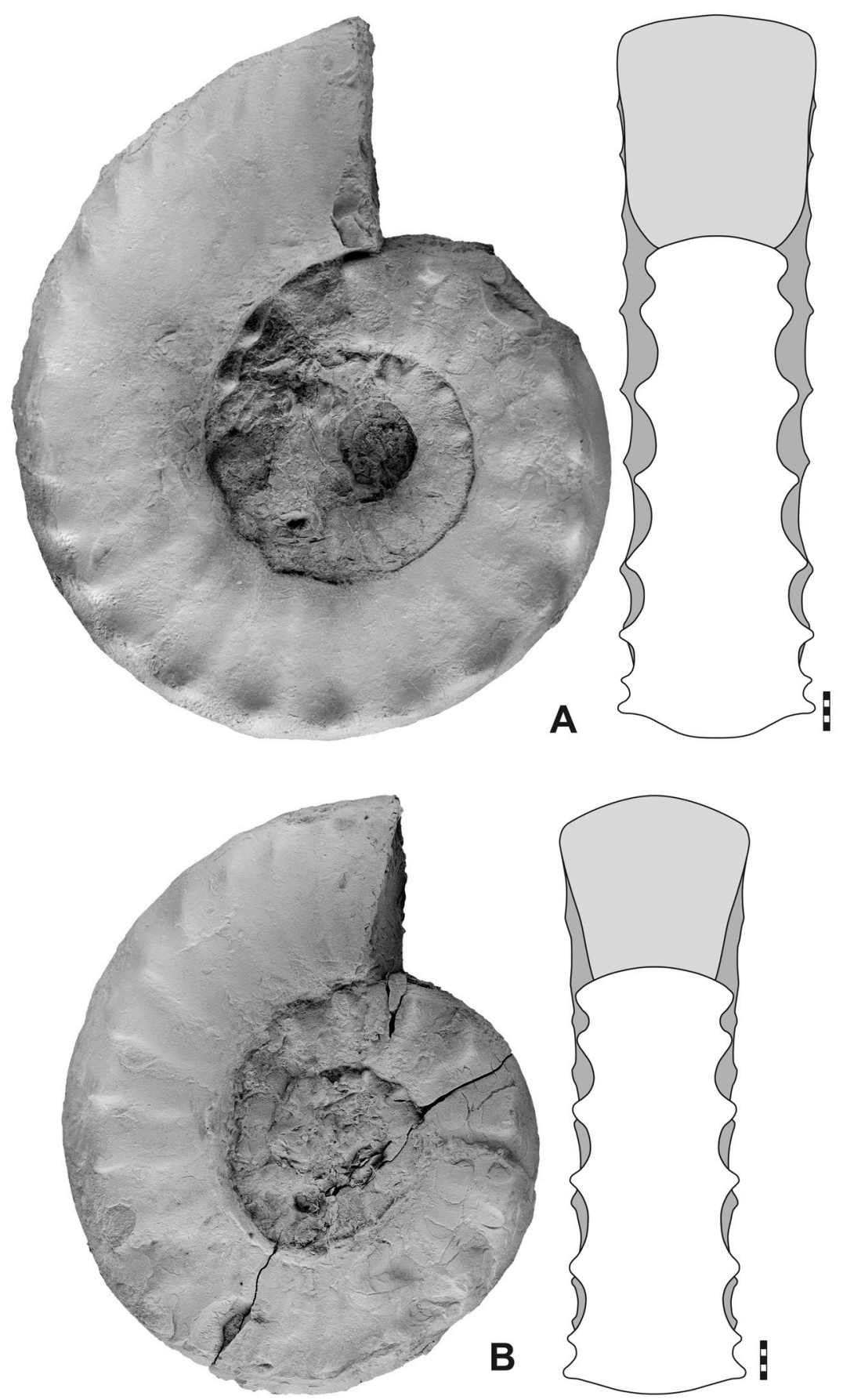

Fig. 42. Clivotirolites decoratus Korn \& Hairapetian gen. et sp. nov., lateral and dorsal views. A. Paratype MB.C.29938, section 1, -1.50 m. B. Paratype MB.C.29944, section E, float. Scale bar units $=1 \mathrm{~mm}$. 
Table 20. Conch dimensions (partly estimated) and ratios of selected specimens of Clivotirolites decoratus Korn \& Hairapetian gen. et sp. nov. from Baghuk Mountain.

\begin{tabular}{ccccccccccc}
\hline Specimen & dm & ww & wh & uw & ah & ww/dm & ww/wh & uw/dm & WER & IZR \\
\hline MB.C.29958 & 91.4 & - & 29.2 & 39.8 & 28.1 & - & - & 0.44 & 2.08 & 0.04 \\
MB.C.29938 & 88.7 & 24.4 & 28.6 & 41.2 & 27.0 & 0.28 & 0.85 & 0.46 & 2.07 & 0.06 \\
MB.C.29947 & 78.2 & - & 24.5 & 33.8 & 23.6 & - & - & 0.43 & 2.05 & 0.04 \\
MB.C.29944 & 77.3 & 24.5 & 24.4 & 33.8 & 22.8 & 0.32 & 1.00 & 0.44 & 2.01 & 0.07 \\
MB.C.29941 & 66.3 & 21.9 & 21.7 & 28.8 & 20.5 & 0.33 & 1.01 & 0.43 & 2.10 & 0.06 \\
MB.C.29961 & 63.2 & 21.8 & 21.3 & 27.2 & 19.4 & 0.34 & 1.02 & 0.43 & 2.08 & 0.09 \\
MB.C.29946 & 58.8 & 17.8 & 19.7 & 25.7 & 18.1 & 0.30 & 0.90 & 0.44 & 2.09 & 0.08 \\
MB.C.29942 & 89.6 & 23.1 & 29.8 & 40.0 & 28.8 & 0.26 & 0.78 & 0.45 & 2.17 & 0.03 \\
MB.C.29948 & 86.4 & 20.5 & 29.0 & 37.5 & 27.5 & 0.24 & 0.71 & 0.43 & 2.15 & 0.05 \\
MB.C.29939 & 84.5 & 24.0 & 27.7 & 38.0 & 26.7 & 0.28 & 0.87 & 0.45 & 2.14 & 0.04 \\
MB.C.29959 & 84.4 & 21.0 & 27.5 & 38.6 & 26.0 & 0.25 & 0.76 & 0.46 & 2.09 & 0.05 \\
MB.C.29941 & 83.6 & 21.0 & 27.0 & 37.2 & 26.0 & 0.25 & 0.78 & 0.44 & 2.11 & 0.04 \\
MB.C.29953 & 79.9 & 19.9 & 26.8 & 35.9 & 26.0 & 0.25 & 0.74 & 0.45 & 2.20 & 0.03 \\
MB.C.29951 & 77.8 & 19.1 & 26.4 & 33.0 & 26.0 & 0.25 & 0.72 & 0.42 & 2.26 & 0.02 \\
MB.C.29943 & 73.2 & 22.6 & 26.5 & 31.1 & 25.0 & 0.31 & 0.85 & 0.42 & 2.31 & 0.06 \\
MB.C.29952 & 69.0 & 20.2 & 24.6 & 29.7 & 24.0 & 0.29 & 0.82 & 0.43 & 2.35 & 0.02 \\
MB.C.29954 & 61.4 & 16.2 & 21.2 & 27.4 & 20.2 & 0.26 & 0.76 & 0.45 & 2.22 & 0.05 \\
\hline
\end{tabular}

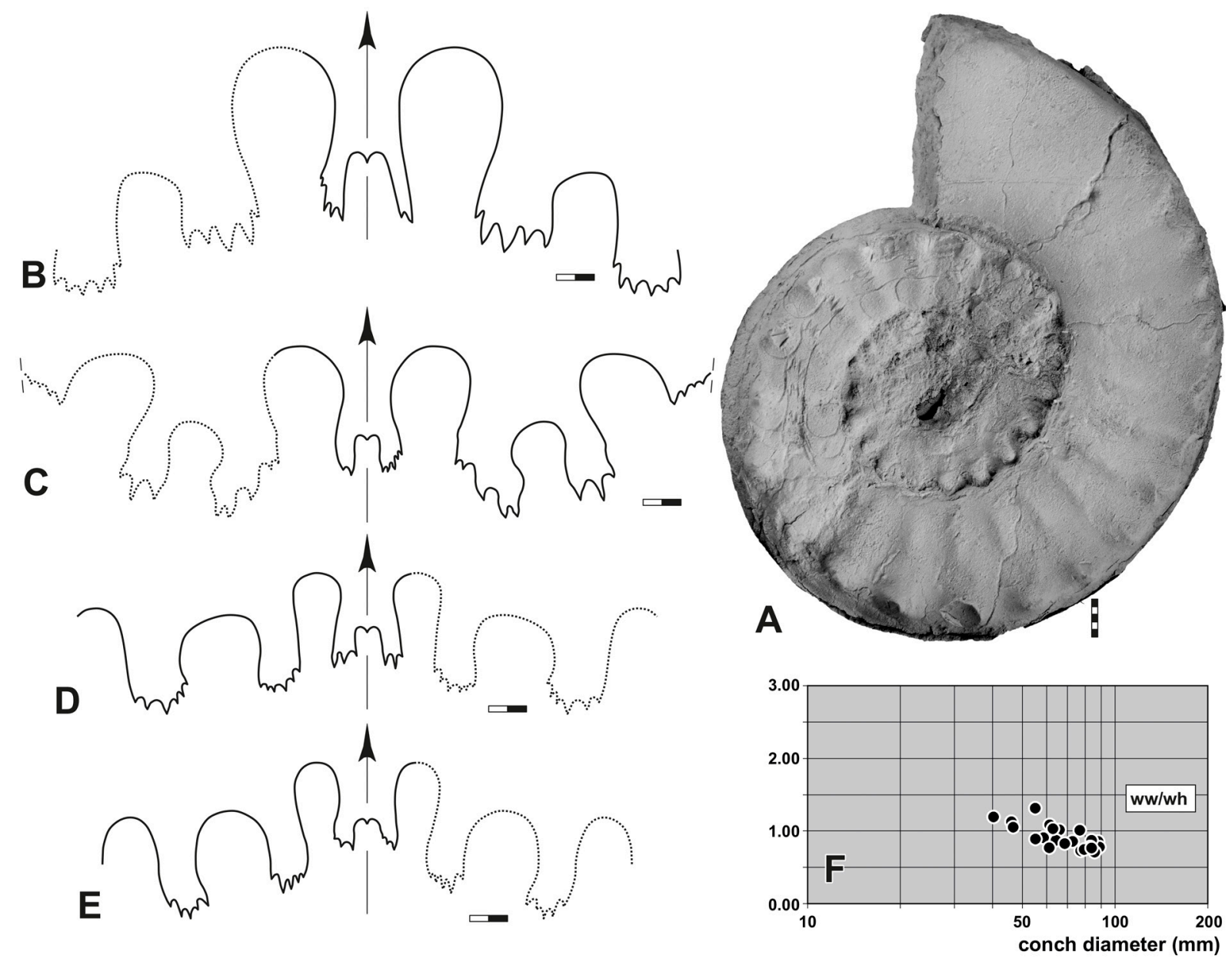

Fig. 43. Clivotirolites decoratus Korn \& Hairapetian gen. et sp. nov. A. Lateral view, paratype MB.C.29958, section G, float. B. Suture line, paratype MB.C.29938, at $17.8 \mathrm{~mm}$ wh. C. Suture line, paratype MB.C.29944, at $15.6 \mathrm{~mm}$ wh. D. Suture line, holotype MB.C.29941, at $13.2 \mathrm{~mm}$ wh. E. Suture line, paratype MB.C.29946, at $13.0 \mathrm{~mm}$ ww, $11.2 \mathrm{~mm}$ wh. F. Whorl profile proportions. Abbreviations: see Material and methods. Scale bar units $=1 \mathrm{~mm}$. 
Clivotirolites petilus Korn \& Hairapetian gen. et sp. nov. urn:lsid:zoobank.org:act:6608C3B9-8B98-4E05-91E6-DA463119748F

Fig. 44; Table 21

\section{Diagnosis}

Species of Clivotirolites gen. nov. with conch reaching $120 \mathrm{~mm} \mathrm{dm}$. Subadult stage with trapezoidal, weakly compressed whorl profile $(\mathrm{ww} / \mathrm{wh}=0.90)$ and flattened tectiform; 15 coarse ventrolateral nodes per volution. Adult stage with trapezoidal, weakly compressed whorl profile $(\mathrm{ww} / \mathrm{wh}=0.70)$, flat venter and angular ventrolateral shoulder; weak ribs and ventrolateral nodes. Prongs of external lobe bifid; altogether 16 notches of $\mathrm{E}, \mathrm{A}$ and $\mathrm{L}$ lobes.

\section{Etymology}

From the Latin 'petilus', meaning 'slim', because of the slender conch.

\section{Material examined}

\section{Holotype}

IRAN • Esfahan Province, Baghuk Mountain E section; Hambast Formation; illustrated in Fig. 44A; MB.C.29962.

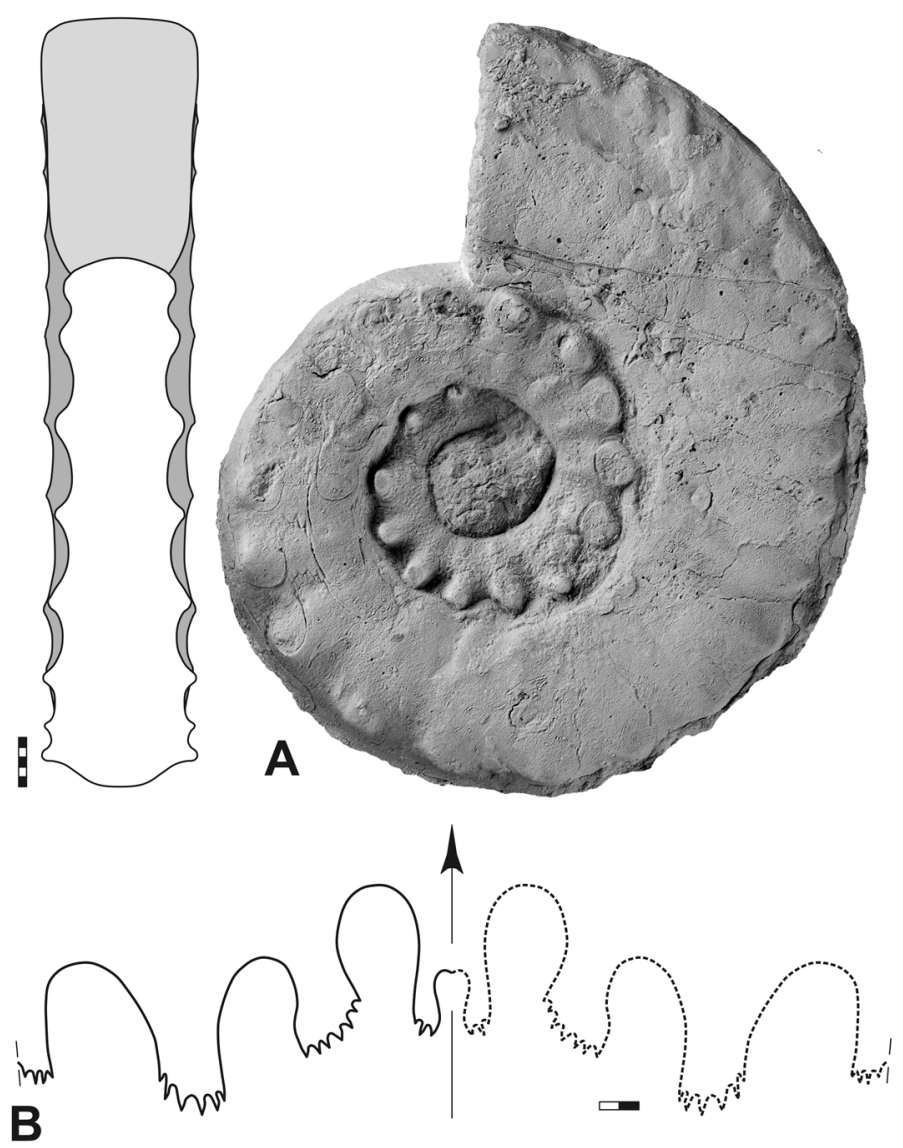

Fig. 44. Clivotirolites petilus Korn \& Hairapetian gen. et sp. nov. A. Lateral and dorsal view, holotype MB.C.29962, section E, float. B. Suture line, holotype MB.C.29962, at $45.5 \mathrm{~mm} \mathrm{dm}, 14.9 \mathrm{~mm}$ wh. Abbreviations: see Material and methods. Scale bar units $=1 \mathrm{~mm}$. 
Table 21. Conch dimensions (partly estimated) and ratios of selected specimens of Clivotirolites petilus Korn \& Hairapetian gen. et sp. nov. from Baghuk Mountain.

\begin{tabular}{ccccccccccc}
\hline Specimen & dm & ww & wh & uw & ah & ww/dm & ww/wh & uw/dm & WER & IZR \\
\hline MB.C.29962 & 79.9 & 16.5 & 28.0 & 33.2 & 24.9 & 0.21 & 0.59 & 0.42 & 2.11 & 0.11 \\
MB.C.29962 & 56.4 & 15.5 & 17.8 & 25.0 & - & 0.27 & 0.87 & 0.44 & - & - \\
\hline
\end{tabular}

\section{Description}

Holotype MB.C.29962 is a comparatively well-preserved individual with $80 \mathrm{~mm}$ conch diameter and allows the study of two whorls (Fig. 44A). Nearly three quarters of the last volution belong to the body chamber. The adult whorl profile is compressed (ww/wh $\sim 0.80)$ and weakly trapezoidal with gently diverging flanks, a subangular ventrolateral shoulder and a flattened but still weakly rounded venter. The sculpture of the last phragmocone volution has 15 coarse ventrolateral nodes. With beginning of the terminal body chamber, these nodes become weaker and more numerous; at the end of the body chamber, ten faint nodes occur in a quarter of a volution.

The suture line of the holotype has an external lobe with weakly converging flanks. Its prongs are slightly pouched and possess three denticles. The ventrolateral saddle is inflated and followed by an asymmetric, pouched adventive lobe with oblique, weakly rounded base and seven small notches. The lateral lobe is generally V-shaped with weakly diverging flanks; it has six notches (Fig. 44B).

\section{Remarks}

Clivotirolites petilus gen. et sp. nov. differs in the lower number (about 15 per volution) of ventrolateral nodes from the species of Clivotirolites decorates gen. et sp. nov.

\section{Stratigraphic range}

The single specimen was collected from float of the upper part of the Hambast Formation.

Genus Esfahanites Korn \& Hairapetian gen. nov. urn:1sid:zoobank.org:act:61EDFE2C-1650-4303-BDC4-3E9F0434CDB8

\section{Type species}

Esfahanites armatus Korn \& Hairapetian gen. et sp. nov., Baghuk Mountain.

\section{Diagnosis}

Representative of the family Dzhulfitidae with large conch; maximum adult diameters about $120 \mathrm{~mm}$. Adult stage with trapezoidal whorl profile. Subadult stage with conical ventrolateral nodes, adult stage with weak ribs. Suture line with very small external lobe reaching only half the depth of adventive lobe.

\section{Etymology}

Named after the city of Esfahan.

\section{Included species}

Esfahanites armatus Korn \& Hairapetian gen. et sp. nov.

\section{Remarks}

Esfahanites gen. nov. differs from Paratirolites and related genera in the very small external lobe. 
Esfahanites armatus Korn \& Hairapetian gen. et sp. nov. urn:1sid:zoobank.org:act:DACEC5B2-4BE5-40D0-AA2B-578741DC349C

Figs 45-46; Table 22

? Paratirolites sp. Ghaedi et al., 2009: pl. 2 figs 1, 4.

? Paratirolites waageni - Zakharov \& Mussavi Abnavi 2013: text-fig. 12c.

\section{Diagnosis}

Species of Esfahanites gen. nov. with conch reaching $130 \mathrm{~mm} \mathrm{dm}$. Subadult stage with strongly trapezoidal, moderately depressed whorl profile $(\mathrm{ww} / \mathrm{wh}=1.50-1.70)$ and rounded to tectiform venter; about 12 coarse ventrolateral nodes per volution. Adult stage with trapezoidal and moderately depressed whorl profile $(\mathrm{ww} / \mathrm{wh}=1.50-1.70)$, flattened tectiform venter and angular ventrolateral shoulder; coarse rursiradiate ribs. Prongs of external lobe trifid or multiply serrated; altogether 15-21 notches of E, A and L lobes.

\section{Etymology}

From the Latin 'armatus', meaning 'armed', because of the coarse spiny sculpture.

\section{Material examined}

Holotype

IRAN - Esfahan Province, Baghuk Mountain E section; Hambast Formation; illustrated in Fig. 45; MB.C.29964.

\section{Paratypes}

IRAN • 1 specimen; Esfahan Province, Baghuk Mountain A section; Hambast Formation; MB.C.29963 • 1 specimen; Esfahan Province, Baghuk Mountain E section; Hambast Formation; MB.C.29965 • 1 specimen; Esfahan Province, Baghuk Mountain G section; Hambast Formation; MB.C.29966 • 2 specimens; Esfahan Province, Baghuk Mountain H section; Hambast Formation; MB.C.29967 to MB.C.29968.

\section{Description}

Holotype MB.C.29964 is the best-preserved specimen; it has $106 \mathrm{~mm}$ conch diameter and allows the study of two whorls (Fig. 45A). The diameter of the phragmocone is $68 \mathrm{~mm}$ and the body chamber has a length of about 270 degrees. Throughout the last two preserved volutions, the whorl profile is trapezoidal, but with the flanks less strongly diverging at the end of growth. The venter is broadly rounded in the penultimate whorl and becomes more flattened on the terminal body chamber. The sculpture on the phragmocone has 14 coarse conical ventrolateral nodes on the last volution; these nodes show a rib-like elongation towards the umbilicus. The sculpture on the body chamber shows variably coarse, rounded ribs on the flank; they turn backward near the umbilicus and are strengthened in the ventrolateral area.

The suture line of holotype MB.C.29964 is remarkable because of its very small external lobe, which is wider at the base and is constricted in the upper part (Fig. 45B). The prongs are inclined ventrally and possess five little notches each. The ventrolateral saddle is small and inflated. The asymmetric adventive lobe is strongly serrated with little notches being developed on the ventral side up to half of the lobe depth. The lateral lobe is slightly less strongly serrated than the adventive lobe.

Paratype MB.C.29966 is an incomplete but otherwise rather well-preserved individual of $101 \mathrm{~mm}$ conch diameter; it allows the study of two and a half whorls (Fig. 46A). The body chamber begins at $60 \mathrm{~mm}$ conch diameter, meaning that the preserved part of the body chamber has a length of 270 degrees and 
is nearly complete. Conch shape changes can be observed during the last whorl of the specimen. While the whorl profile is circular with rounded venter at the binning of the last whorl, it changes to tectiform and has, at the end of growth, an almost flat venter, separated from the flat and diverging flanks by an angular ventrolateral shoulder. The sculpture of the phragmocone part of the specimen shows coarse conical nodes in the ventrolateral area, 12 on the last volution and 10 on the penultimate volution. At the beginning of the terminal body chamber, these nodes are transformed into elongate nodes and finally rounded ribs, which turn from the umbilicus in backward direction. Finally, at the end of the body chamber these ribs become weaker and only shallow rounded ribs and weak ventrolateral nodes can be seen.

The suture line of paratype MB.C.29966 shows a very small external lobe that has not half the depth of the adventive lobe (Fig. 46B). It is parallel-sided with parallel-sided prongs that possess three small
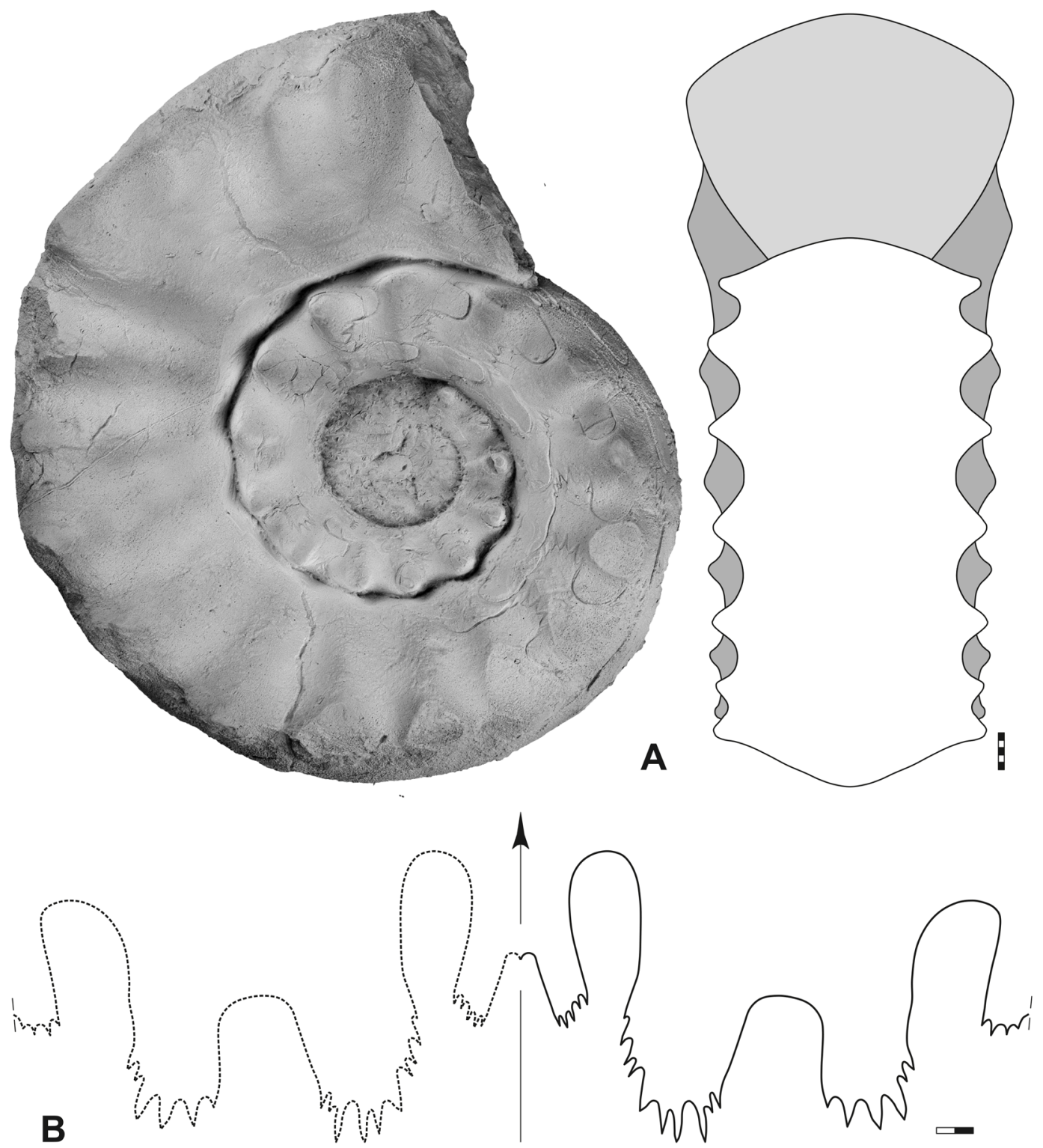

Fig. 45. Esfahanites armatus Korn \& Hairapetian gen. et sp. nov., holotype MB.C.29964, section E, float. A. Lateral and dorsal view. B. Suture line, at $58.0 \mathrm{~mm} \mathrm{dm}, 35.0 \mathrm{~mm}$ ww, $22.0 \mathrm{~mm}$ wh. Abbreviations: see Material and methods. Scale bar units $=1 \mathrm{~mm}$. 
Table 22. Conch dimensions (partly estimated) and ratios of selected specimens of Esfahanites armatus Korn \& Hairapetian gen. et sp. nov. from Baghuk Mountain.

\begin{tabular}{ccccccccccc}
\hline Specimen & dm & ww & wh & uw & ah & ww/dm & ww/wh & uw/dm & WER & IZR \\
\hline MB.C.29964 & 105.8 & 51.6 & 32.0 & 46.3 & 29.5 & 0.49 & 1.61 & 0.44 & 1.92 & 0.08 \\
MB.C.29964 & 78.1 & 42.0 & 26.0 & 31.6 & - & 0.54 & 1.62 & 0.40 & - & - \\
MB.C.29966 & 101.2 & - & 34.0 & 43.9 & 32.9 & - & - & 0.43 & 2.20 & 0.03 \\
MB.C.29966 & 67.3 & 34.5 & 21.3 & 30.5 & - & 0.51 & 1.62 & 0.45 & - & - \\
MB.C.29965 & 96.5 & - & 32.5 & 38.5 & 30.5 & - & - & 0.40 & 2.14 & 0.06 \\
MB.C.29965 & 69.5 & 33.5 & 22.0 & 28.0 & - & 0.48 & 1.52 & 0.40 & - & - \\
\hline
\end{tabular}
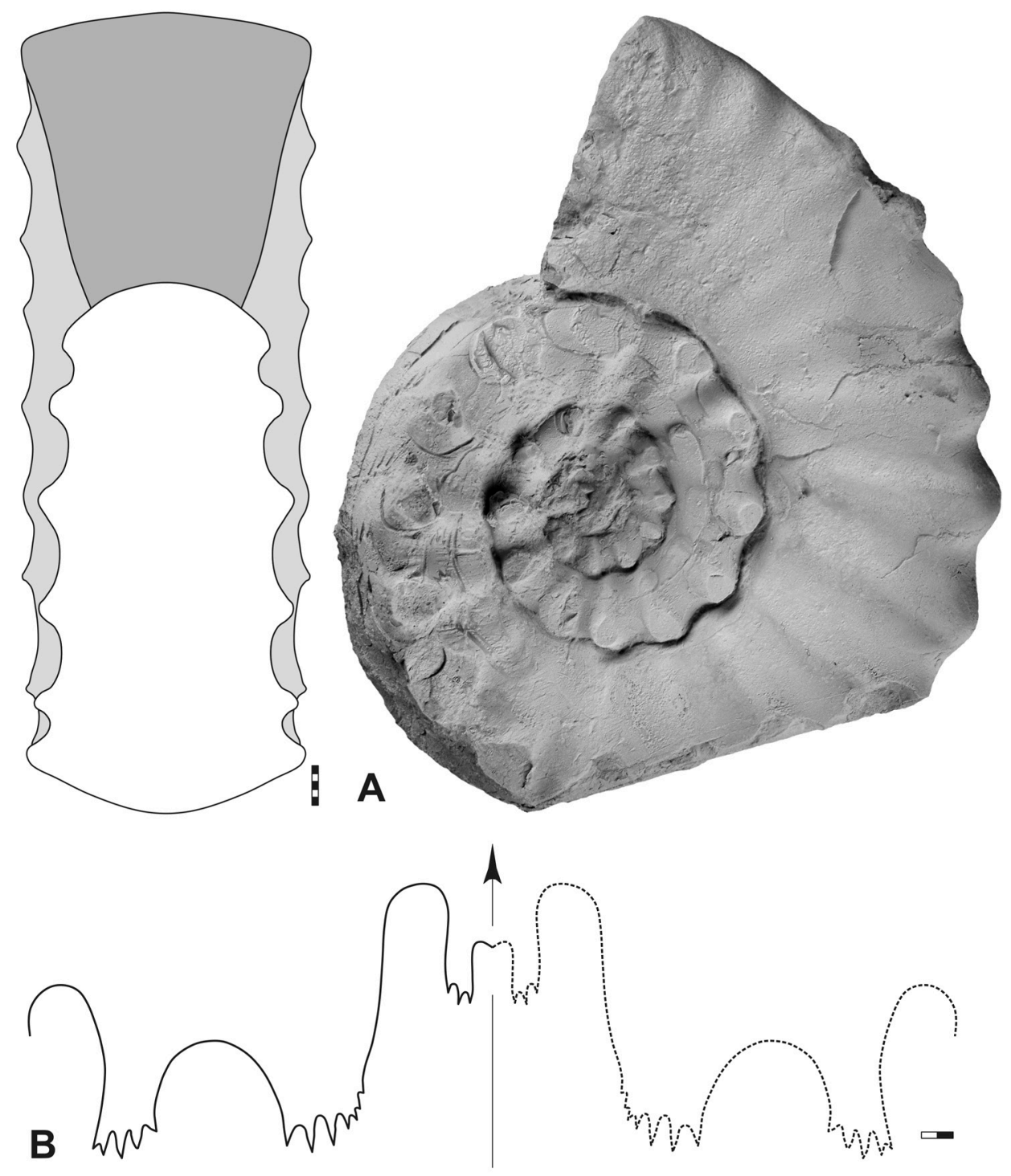

Fig. 46. Esfahanites armatus Korn \& Hairapetian gen. et sp. nov., paratype MB.C.29966, section G, float. A. Lateral and dorsal view. B. Suture line, at $56.0 \mathrm{~mm} \mathrm{dm}, 36.0 \mathrm{~mm}$ ww, $19.0 \mathrm{~mm}$ wh. Abbreviations: see Material and methods. Scale bar units $=1 \mathrm{~mm}$. 
notches. The ventrolateral saddle is inverted U-shaped with a much longer dorsal flank. The adventive lobe has seven small notches and the lateral lobe five, both lobes are asymmetric and separated by a low semi-circular lateral saddle.

\section{Remarks}

Esfahanites armatus gen. et sp. nov. differs in the very small external lobe from all the species of Paratirolites. It can therefore not be confused with any other species.

\section{Stratigraphic range}

Upper part of the Hambast Formation; the only in situ collected specimen comes from $2.00 \mathrm{~m}$ below the extinction horizon (Alibashites ferdowsii Zone).

Genus Alibashites Korn \& Ghaderi in Korn et al., 2016

\section{Type species}

Xenodiscus (Paratirolites?) Mojsisovicsi Stoyanow, 1910, by original designation.

\section{Included species}

Alibashites ferdowsii Korn \& Ghaderi in Korn et al., 2016; Xenodiscus (Paratirolites?) Mojsisovicsi Stoyanow, 1910; Alibashites uncinatus Korn \& Ghaderi in Korn et al., 2016.

\section{Diagnosis}

Representatives of the family Dzhulfitidae with moderately large to large conch; maximum adult diameters $90 \mathrm{~mm}$. Adult stage with subtrapezoidal or quadrate whorl profile. Subadult stage with large conical ventrolateral nodes, adult stage with weak ribs. Suture line with deep external lobe; depths of external lobe and adventive lobe nearly identical.

\section{Remarks}

Alibashites has an intermediate morphological position between Paratirolites and Abichites. It possesses the subadult sculpture with conical ventrolateral nodes of Paratirolites but lacks the trapezoidal whorl profile of that genus. Abichites has a similar adult conch morphology with a rectangular or subtrapezoidal whorl profile but does not possess the strong ventrolateral nodes developed in Alibashites.

Alibashites mojsisovicsi (Stoyanow, 1910)

Fig. 47; Table 23

Xenodiscus (Paratirolites?) Mojsisovicsi Stoyanow, 1910: 79, pl. 8 fig. 1.

Abichites mojsisovicsi - Shevyrev 1965: 180, pl. 23 fig. 4; 1968: 95, pl. 4 fig. 3. — Stepanov et al. 1969: pl. 13 fig. 4.

Alibashites mojsisovicsi - Korn \& Ghaderi in Korn et al. 2016: 870, text-fig. 29.

\section{Diagnosis}

Alibashites with conch reaching $90 \mathrm{~mm} \mathrm{dm}$. Subadult stage with circular, weakly depressed whorl profile $(\mathrm{ww} / \mathrm{wh}=1.00-1.20)$ and rounded venter; 13 coarse ventrolateral nodes per volution. Adult stage with quadrate and weakly compressed whorl profile $(\mathrm{ww} / \mathrm{wh}=0.95-1.00)$, almost flat venter and subangular 
ventrolateral shoulder; low ribs on flanks, forming very weak dorsolateral and ventrolateral nodes. Prongs of external lobe variable, simple to trifid; 8-13 notches of E, A and L lobes.

\section{Material examined}

IRAN • 1 specimen; Esfahan Province, Baghuk Mountain C section; Hambast Formation; MB.C.29969 • 1 specimen; Esfahan Province, Baghuk Mountain H section; Hambast Formation; MB.C.299670 • 2 specimens; Esfahan Province, Baghuk Mountain; Hambast Formation; MB.C.299671 to MB.C.29972.

\section{Description}

Specimen MB.C.29969 has $55 \mathrm{~mm}$ conch diameter with a moderately well-preserved last volution of the phragmocone but a weathered body chamber (Fig. 47A). It possesses a nearly quadrate whorl profile with angular ventrolateral shoulder and weakly concave venter at its largest diameter. Half of a whorl earlier, the venter is nearly flat and another half of a whorl earlier, it is broadly convex. At this stage, the whorl profile is trapezoidal with strongly diverging flanks. The sculpture of the phragmocone shows about 20 ventrolateral nodes with a tendency to become weaker during growth of the conch.

The suture line of specimen MB.C.29969 shows a V-shaped external lobe with diverging flanks, a parallel-sided ventrolateral saddle with weak dorsal inclination and adventive and lateral lobes with moderate serration (Fig. 47B). They are separated by a rather low, symmetric lateral saddle.

\section{Remarks}

Alibashites ferdowsii also has coarse nodes in the subadult stage like A. mojsisovicsi, but this species shows a much wider whorl profile (ww/wh $=1.25-1.50)$ than $A$. mojsisovicsi $(w w / w h=0.95-1.00)$ in the adult stage. A. mojsisovicsi differs from the species of Abichites, which may develop a similar adult stage, in the coarse subadult ventrolateral nodes.

\section{Stratigraphic range}

Upper part of the Hambast Formation; 1.35 to $0.75 \mathrm{~m}$ below the extinction horizon (upper part of the Lutites profundus Zone to Abichites stoyanowi Zone).
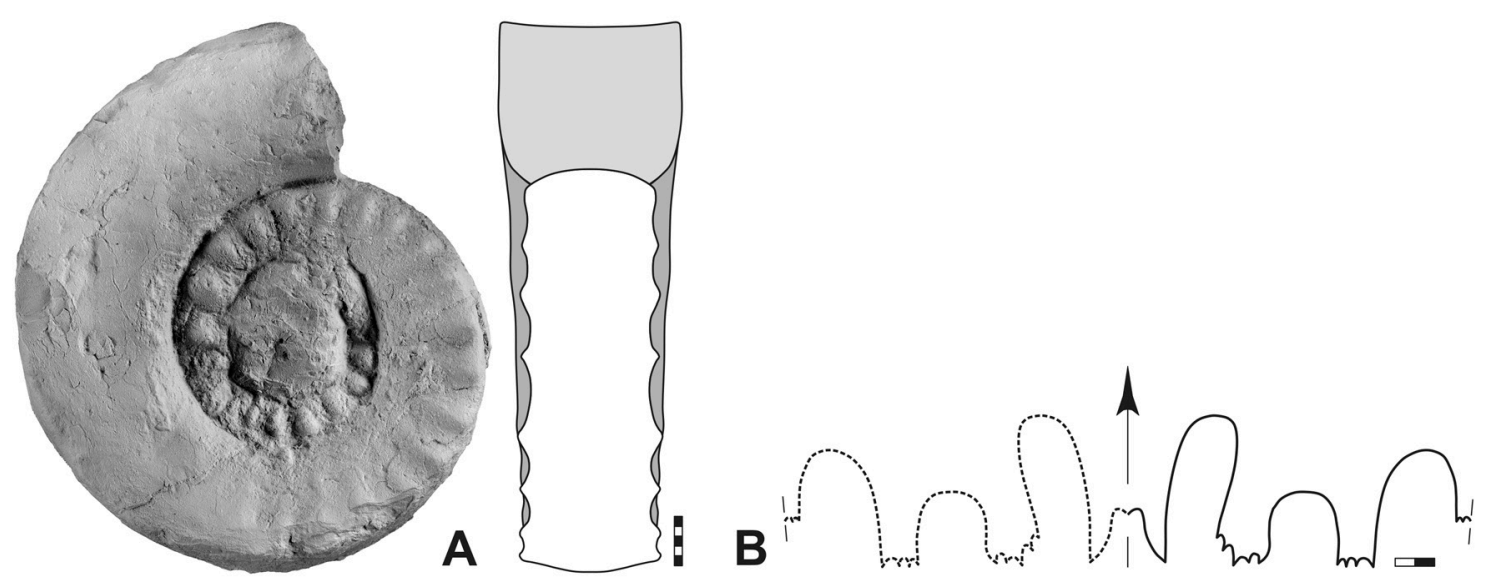

Fig. 47. Alibashites mojsisovicsi (Stoyanow, 1910) A. Lateral and dorsal view, specimen MB.C.29969, section C, $-0.75 \mathrm{~m}$. B. Suture line, specimen MB.C.29969, at $12.6 \mathrm{~mm}$ wh. Abbreviation: see Material and methods. Scale bar units $=1 \mathrm{~mm}$. 
Table 23. Conch dimensions (partly estimated) and ratios of selected specimens of Alibashites mojsisovicsi (Stoyanow, 1910) from Baghuk Mountain.

\begin{tabular}{ccccccccccc}
\hline Specimen & $\mathbf{d m}$ & $\mathbf{w w}$ & $\mathbf{w h}$ & $\mathbf{u w}$ & $\mathbf{a h}$ & $\mathbf{w w} / \mathbf{d m}$ & $\mathbf{w w} / \mathbf{w h}$ & $\mathbf{u w} / \mathbf{d m}$ & WER & IZR \\
\hline MB.C.29969 & 55.2 & & 16.6 & 26.7 & 16.2 & - & - & 0.48 & 2.00 & 0.03 \\
MB.C.29969 & 43.1 & 17.1 & 14.5 & 20.6 & - & 0.40 & 1.18 & 0.48 & - & - \\
MB.C.29972 & 48.2 & 17.3 & 13.3 & 19.7 & - & 0.36 & 1.30 & 0.41 & - & - \\
MB.C.29970 & 46.5 & 18.3 & 15.0 & 20.8 & 14.4 & 0.39 & 1.22 & 0.45 & 2.10 & 0.04 \\
\hline
\end{tabular}

Alibashites ferdowsii Korn \& Ghaderi in Korn et al., 2016

Figs 48-49; Table 24

Alibashites ferdowsii Korn \& Ghaderi in Korn et al., 2016: 871, text-fig. 30.

\section{Diagnosis}

Species of Alibashites with conch reaching $100 \mathrm{~mm}$ dm. Subadult stage with circular to subtrapezoidal, weakly depressed whorl profile (ww/wh $=1.25-1.50$ ) and broadly rounded venter; $10-12$ very coarse ventrolateral nodes. Adult stage with subtrapezoidal and weakly depressed whorl profile (ww/wh $=1.20$ 1.50 ) with converging flanks, almost flat venter and angular ventrolateral shoulder; sharp ribs on flanks, forming short dorsolateral nodes and stronger ventrolateral nodes. Prongs of external lobe variable in shape, bifid to multiply serrated; altogether 15-18 notches of E, A and L lobes.

\section{Material examined}

\section{Holotype}

IRAN - West Azerbaijan, Aras Valley section; Paratirolites Limestone; illustrated by Korn \& Ghaderi in Korn et al. (2016: text-fig. 30a); MB.C.25327.

\section{Additional material}

IRAN • 6 specimens; Esfahan Province, Baghuk Mountain 1 section; Hambast Formation; MB.C.29976 to MB.C.29978 - 1 specimen; Esfahan Province, Baghuk Mountain B section; Hambast Formation; MB.C.29979 - 7 specimens; Esfahan Province, Baghuk Mountain C section; Hambast Formation; MB.C.29980 to MB.C.29986 - 2 specimens; Esfahan Province, Baghuk Mountain E section; Hambast Formation; MB.C.29987 to MB.C.29988 - 2 specimens; Esfahan Province, Baghuk Mountain G section; Hambast Formation; MB.C.29989 to MB.C.29990.

\section{Description}

Specimen MB.C.29974 is the largest available specimen with $59 \mathrm{~mm}$ conch diameter (Fig. 48A). Slightly less than half of a volution belongs to the body chamber. The profile of the aperture is characterised by a broadly rounded umbilical margin, weakly concave flanks, an angular ventrolateral shoulder and a broadly rounded but somehow flattened venter. The whorl profile in this stage is weakly depressed with a ww/wh ratio of 1.35 . One volution earlier, the venter is more rounded and the flanks are widely curved, producing a depressed oval whorl profile. The sculpture changes from the subadult stage with coarse ventrolateral nodes per volution into the body chamber sculpture with sharp dorsolateral ribs, which are connected by low and rounded folds with weak ventrolateral nodes.

The suture line of specimen MB.C.29974 is characterised by a Y-shaped external lobe, of which the prongs are subdivided by four small notches of varying depth. The ventrolateral saddle is strikingly 
asymmetric and dorsally inclined. It is followed by the asymmetric adventive lobe with seven small notches, the asymmetric parabolic lateral saddle and a lateral lobe with three notches (Fig. 49A).

Specimen MB.C.29987 is a specimen with $51 \mathrm{~mm}$ conch diameter. Its profile is subtrapezoidal at the aperture; it shows a convex and oblique umbilical wall and is widest in the dorsolateral portion of the
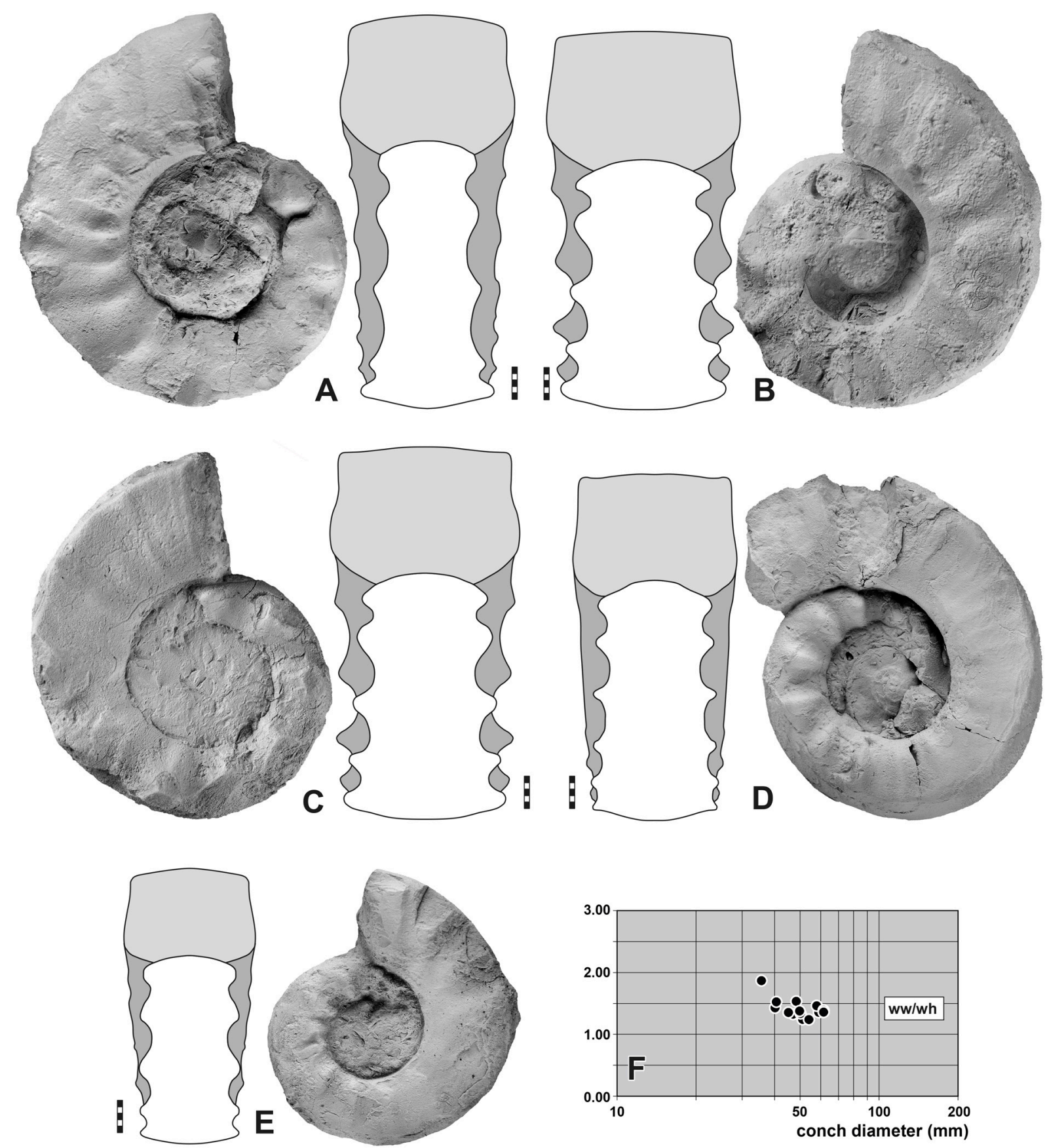

Fig. 48. Alibashites ferdowsii Korn \& Ghaderi, 2016. A. Lateral and dorsal view, specimen MB.C.29974, section 1, -1.60 m. B. Lateral and dorsal view, specimen MB.C.29990, section G, float. C. Lateral and dorsal view, specimen MB.C.29987, section E, float. D. Lateral and dorsal view, specimen MB.C.29980, section C, -1.15 m. E. Lateral and dorsal view, specimen MB.C.29979, section B, float. F. Whorl profile proportions. Scale bar units $=1 \mathrm{~mm}$. 
flank and weakly concave in the outer flank area (Fig. 48C). The flattened venter is separated from the flank by an angular ventrolateral shoulder. One whorl earlier is the whorl profile trapezoidal with a rounded ventrolateral shoulder and a broadly rounded venter. The sculpture on the phragmocone consists of twelve coarse conical nodes; on the body chamber these nodes become weaker and are connected with elongate rounded dorsolateral ribs by shallow, rounded folds.

The suture line shows a slightly pouched external lobe with lanceolate, unsubdivided prongs. The ventrolateral saddle is turned U-shaped with nearly parallel flanks. Both flanks of the adventive lobe stand parallel, but its base is oblique and serrated into six little notches (Fig. 49D).

\section{Remarks}

The specimens from Baghuk Mountain are morphologically very similar to the material from the type area, and the sizes of the specimens are nearly identical. Differences occur in the degree of sutural subdivision; while the prongs of the external lobe in the material from Julfa are secondarily subdivided (two, three or four notches), many of the specimens from Baghuk Mountain show non-subdivided lanceolate prongs.

Alibashites ferdowsii shows an intermediate morphological position between the genera Paratirolites and Abichites. Characteristic for Paratirolites is the intermediate growth stage with trapezoidal whorl profile with the prominent conical ventrolateral nodes; similar to Abichites is the flat venter in the adult stage. The intermediate position of $A$. ferdowsii is also visible in the suture line; on the one side is the more complex external lobe in Paratirolites (with serrated prongs of the external lobe), and on the other side is Abichites (with a trend towards unserrated prongs of the external lobe).

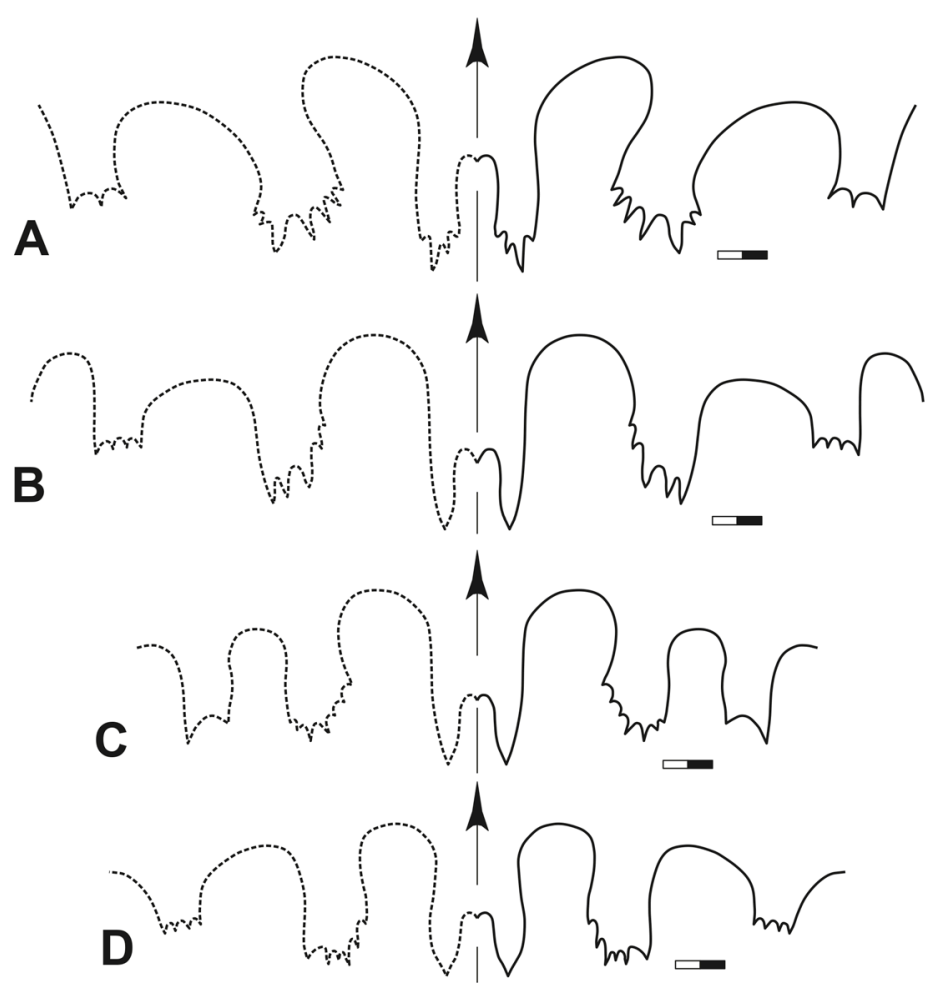

Fig. 49. Alibashites ferdowsii Korn \& Ghaderi, 2016, suture lines. A. MB.C.29974, at $12.8 \mathrm{~mm}$ wh. B. MB.C.29980, at $10.9 \mathrm{~mm}$ wh. C. MB.C.29979, at $14.0 \mathrm{~mm}$ ww, $10.4 \mathrm{~mm}$ wh. D. MB.C.29987, at $10.3 \mathrm{~mm}$ wh. Abbreviations: see Material and methods. Scale bar units $=1 \mathrm{~mm}$. 
Table 24. Conch dimensions (partly estimated) and ratios of selected specimens of Alibashites ferdowsii Korn \& Ghaderi in Korn et al., 2016 from Baghuk Mountain.

\begin{tabular}{ccccccccccc}
\hline Specimen & $\mathbf{d m}$ & $\mathbf{w w}$ & $\mathbf{w h}$ & $\mathbf{u w}$ & $\mathbf{a h}$ & $\mathbf{w w} / \mathbf{d m}$ & $\mathbf{w w} / \mathbf{w h}$ & $\mathbf{u w} / \mathbf{d m}$ & WER & IZR \\
\hline MB.C.29974 & 59.2 & 26.1 & 19.4 & 25.6 & 19.0 & 0.44 & 1.35 & 0.43 & 2.17 & 0.02 \\
MB.C.29990 & 58.1 & 28.0 & 19.3 & 25.1 & 19.2 & 0.48 & 1.45 & 0.43 & 2.23 & 0.01 \\
MB.C.29987 & 51.3 & 21.2 & 17.2 & 22.2 & 16.5 & 0.41 & 1.23 & 0.43 & 2.17 & 0.04 \\
MB.C.29980 & 48.5 & 22.5 & 14.8 & 20.7 & 14.2 & 0.46 & 1.52 & 0.43 & 2.00 & 0.04 \\
MB.C.29979 & 40.2 & 19.7 & 13.9 & 16.6 & 13.3 & 0.49 & 1.42 & 0.41 & 2.23 & 0.04 \\
MB.C.29983 & 61.8 & 26.5 & 19.2 & 26.0 & 18.5 & 0.43 & 1.38 & 0.42 & 2.04 & 0.04 \\
MB.C.29988 & 54.3 & 20.4 & 16.6 & 25.0 & 16.0 & 0.38 & 1.23 & 0.46 & 2.01 & 0.04 \\
MB.C.29981 & 50.4 & 21.5 & 16.2 & 21.5 & 15.4 & 0.43 & 1.33 & 0.43 & 2.07 & 0.05 \\
MB.C.29984 & 50.0 & 24.2 & 17.7 & 20.9 & 17.0 & 0.48 & 1.37 & 0.42 & 2.30 & 0.04 \\
\hline
\end{tabular}

\section{Stratigraphic range}

Upper part of the Hambast Formation; 2.25 to $0.70 \mathrm{~m}$ below the extinction horizon (Alibashites ferdowsii Zone to lower part of the Abichites stoyanowi Zone).

Genus Lutites Korn \& Hairapetian gen. nov.

urn:1sid:zoobank.org:act:5B2AB929-F903-46B0-B108-A1C57458A1DA

\section{Type species}

Lutites lyriformis Korn \& Hairapetian gen. et sp. nov., Baghuk Mountain.

\section{Diagnosis}

Genus of the family Dzhulfitidae with large conch; maximum adult diameters about $140 \mathrm{~mm}$. Adult stage with compressed, subtrapezoidal whorl profile; flanks concave, venter flat or concave. Subadult stage with conical ventrolateral nodes, adult stage with weak ribs or delicate plications. Suture line with deep external lobe (deeper than adventive lobe), ventral prongs unsubdivided or notched.

\section{Etymology}

Named after the Lut Desert, which extends to the North-East of Baghuk Mountain.

\section{Included species}

Alibashites stepanovi Korn \& Ghaderi in Korn et al., 2016; Lutites paucis Korn \& Hairapetian gen. et sp. nov.; Lutites alius Korn \& Hairapetian gen. et sp. nov.; Lutites profundus Korn \& Hairapetian gen. et sp. nov.; Lutites lyriformis Korn \& Hairapetian gen. et sp. nov.; Lutites plicatus Korn \& Hairapetian gen. et sp. nov.

\section{Remarks}

Lutites gen. nov. differs from Paratirolites and related genera in the compressed subtrapezoidal, pearshaped whorl profile and in the very deep external lobe. 
Lutites paucis Korn \& Hairapetian gen. et sp. nov. urn:1sid:zoobank.org:act:9C85D567-DA54-463F-8CE3-BFDBABD83928

Fig. 50; Table 25

\section{Diagnosis}

Species of Lutites gen. nov. with conch reaching $70 \mathrm{~mm} \mathrm{dm}$. Subadult stage with circular, slightly compressed whorl profile (ww/wh $=0.90-1.00)$ and broadly rounded venter; very coarse conical ventrolateral nodes. Adult stage with subtrapezoidal, slightly compressed whorl profile ( $\mathrm{ww} / \mathrm{wh}=0.80)$, flattened venter and subangular ventrolateral shoulder; without ribs or nodes. Prongs of external lobe simple; altogether 11 notches of E, A and L lobes.

\section{Etymology}

From the Latin 'paucis', meaning 'fewer', because of the low number of lobes and nodes.

\section{Material examined}

\section{Holotype}

IRAN - Esfahan Province, Baghuk Mountain C section; Hambast Formation, $2.45 \mathrm{~m}$ below the top; illustrated in Fig. 50A; MB.C.29991.

\section{Paratypes}

IRAN • 2 specimens; Esfahan Province, Baghuk Mountain C section; Hambast Formation; MB.C.29992 to MB.C.29993.

\section{Description}

Holotype MB.C.29991 is a partly corroded specimen with $64 \mathrm{~mm}$ conch diameter with two thirds of the last volution belonging to the body chamber (Fig. 50A). At the end of the body chamber, the whorl profile is subtrapezoidal with a broadly rounded umbilical margin, converging flanks, a narrowly rounded ventrolateral shoulder and a flattened venter. By contrast, the whorl profile is trapezoidal at the beginning of the body chamber and subcircular in the last portion of the phragmocone. The sculpture of the phragmocone consists of very coarse conical ventrolateral nodes (eight per volution). The body chamber appears to be smooth.
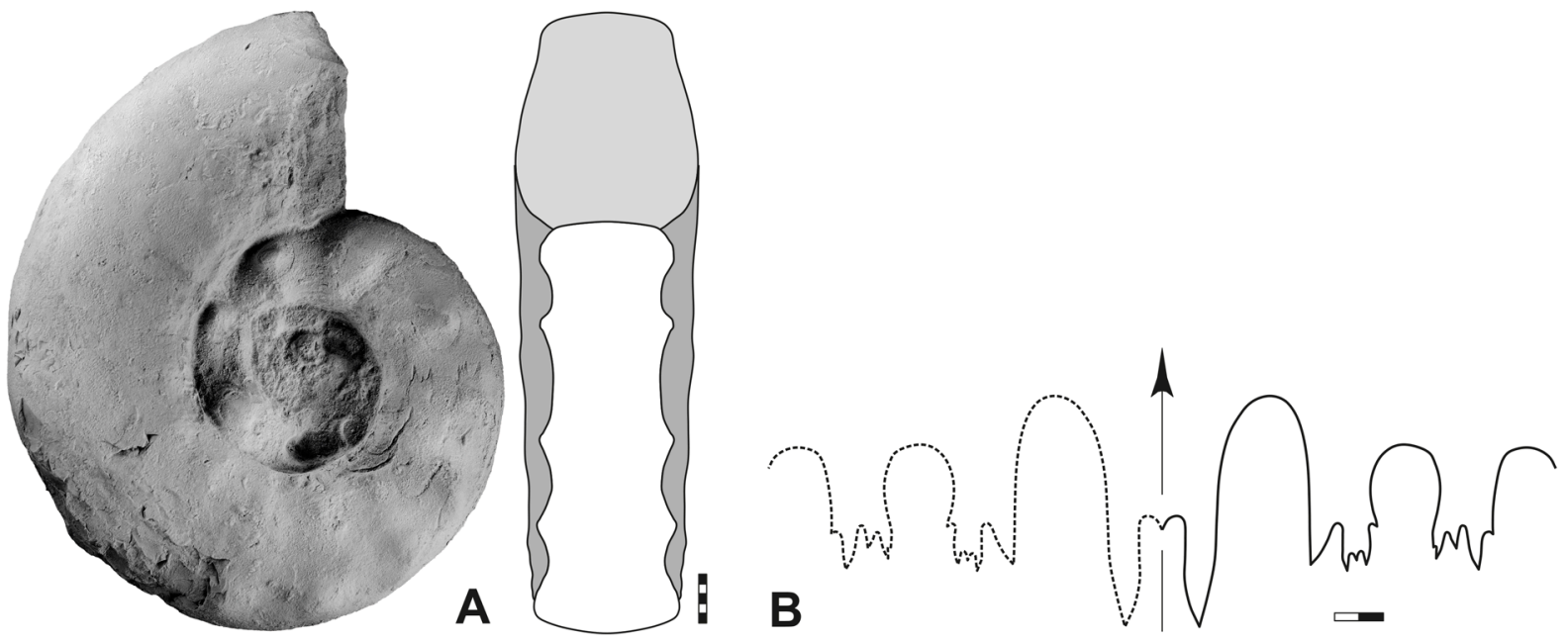

Fig. 50. Lutites paucis Korn \& Hairapetian gen. et sp. nov. A. Lateral and dorsal view, holotype MB.C.29991, section C, -2.45 m. B. Suture line, holotype MB.C.29991, at $13.7 \mathrm{~mm}$ wh. Abbreviation: see Material and methods. Scale bar units $=1 \mathrm{~mm}$. 
Table 25. Conch dimensions (partly estimated) and ratios of the holotype of Lutites paucis Korn \& Hairapetian gen. et sp. nov. from Baghuk Mountain.

\begin{tabular}{ccccccccccc}
\hline Specimen & dm & ww & wh & uw & ah & ww/dm & ww/wh & uw/dm & WER & IZR \\
\hline MB.C.29991 & 64.3 & 18.8 & 23.5 & 24.1 & 22.8 & 0.29 & 0.80 & 0.37 & 2.40 & 0.03 \\
MB.C.29991 & 44.3 & 15.9 & 16.7 & 16.9 & - & 0.36 & 0.95 & 0.38 & - & - \\
\hline
\end{tabular}

The suture line of the holotype has a large external lobe with weakly diverging flanks and simple, narrow and lanceolate prongs. The ventrolateral saddle is narrowly rounded and the lateral saddle is weakly inflated. Both the adventive lobe and the lateral lobe are parallel-sided and both characterised by five notches that are very dissimilar in size (Fig. 50B).

\section{Remarks}

Lutites paucis gen. et sp. nov. differs from the other species of the genus in the stouter conch, the only weakly flattened venter and the lower number of conical nodes. The new species may represent an intermediate form between Alibashites and Lutites gen. nov.

\section{Stratigraphic range}

Upper part of the Hambast Formation; $2.45 \mathrm{~m}$ to $1.20 \mathrm{~m}$ below the extinction horizon (uppermost part of the Paratirolites kittli Zone to the Lutites profundus Zone).

Lutites lyriformis Korn \& Hairapetian gen. et sp. nov. urn:lsid:zoobank.org:act:3FC3DB4D-AA14-43A6-B982-0137ED22D6B7

Figs 51-52; Table 26

\section{Diagnosis}

Species of Lutites gen. nov. with conch reaching $140 \mathrm{~mm} \mathrm{dm}$. Subadult stage with parallel-sided, compressed whorl profile $(\mathrm{ww} / \mathrm{wh}=0.60-0.70)$ and rounded venter; about 14 ventrolateral nodes per volution. Adult stage with subtrapezoidal, compressed whorl profile $(\mathrm{ww} / \mathrm{wh}=0.50-0.60)$, concave flanks, concave venter and angular ventrolateral shoulder; numerous weak and densely arranged ribs. Prongs of external lobe bifid to multiply serrated; altogether 13-22 notches of E, A and L lobes.

\section{Etymology}

From the Latin 'lyra', referring to the shape of the whorl profile.

\section{Material examined}

\section{Holotype}

IRAN • Esfahan Province, Baghuk Mountain A section; Hambast Formation; illustrated in Fig. 51A; MB.C.29995.

\section{Paratypes}

IRAN • 1 specimen; Esfahan Province, Baghuk Mountain 1 section; Hambast Formation; MB.C.29994 • 2 specimens; Esfahan Province, Baghuk Mountain C section; Hambast Formation; MB.C.29996 to MB.C.29997 - 1 specimen; Esfahan Province, Baghuk Mountain E section; Hambast Formation; MB.C.29998 - 1 specimen; Esfahan Province, Baghuk Mountain G section; Hambast Formation; MB.C.29999 - 2 specimens; Esfahan Province, Baghuk Mountain H section; Hambast Formation; MB.C.30000 to MB.C.30001. 

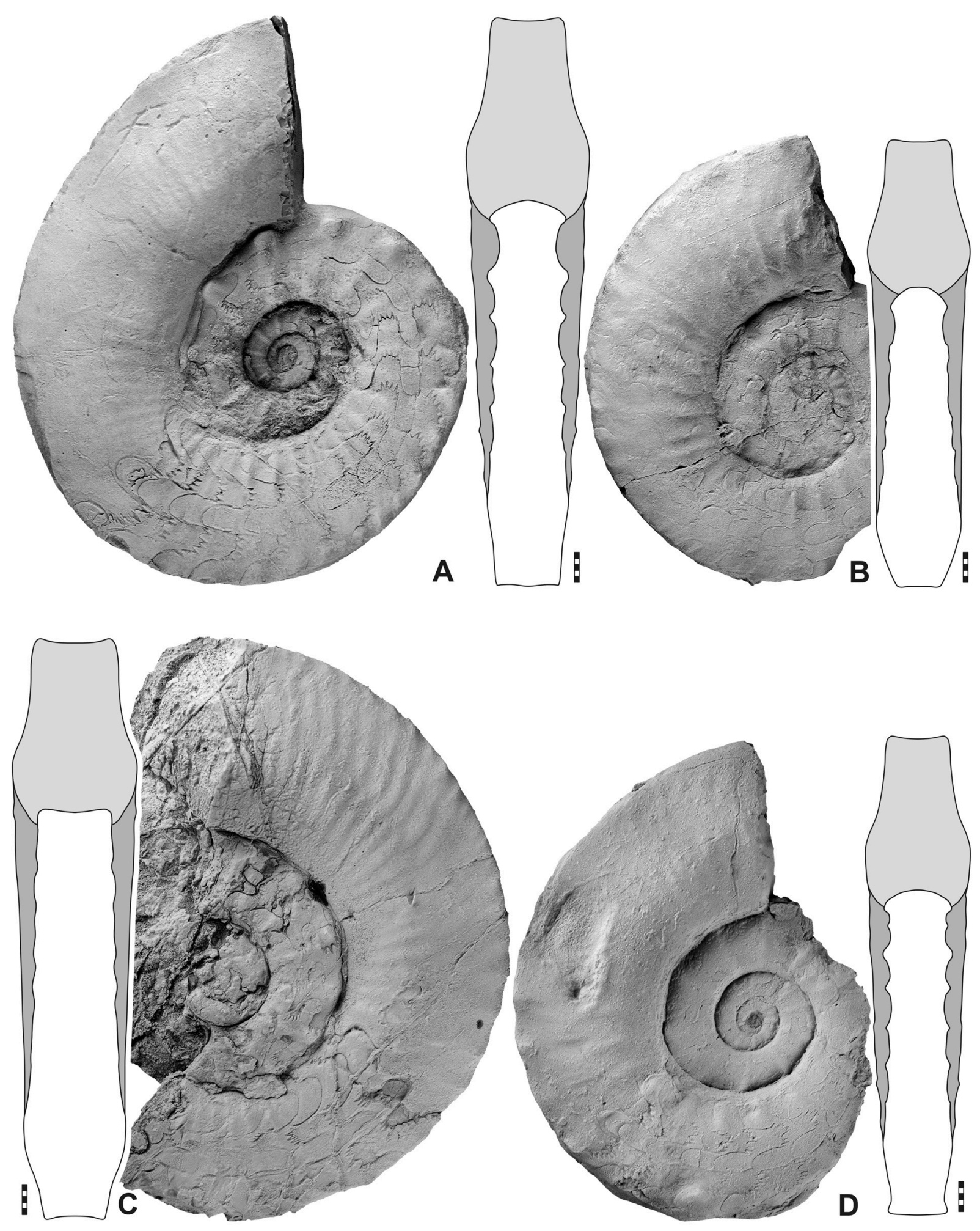

Fig. 51. Lutites lyriformis Korn \& Hairapetian sp. nov., lateral and dorsal views. A. Holotype MB.C.29995, section A, float. B. Paratype MB.C.29997, section C, -1.00 m. C. Paratype MB.C.29996, section C, $-1.45 \mathrm{~m}$. D. Paratype MB.C.29999, section G, $-1.20 \mathrm{~m}$. Scale bar units =1 mm. 


\section{Description}

Holotype MB.C.29995 is a rather well-preserved specimen with $96 \mathrm{~mm}$ conch diameter (Fig. 51A). It allows the study of three and a half volutions, of which only one third of a volution belongs to the body chamber. Adulthood is indicated by the weak crowding of the last septa at $73 \mathrm{~mm}$ diameter. The whorl profile is, at the largest preserved conch diameter, subtrapezoidal with a broadly rounded umbilical margin and concave and converging flanks. The weakly concave venter is separated from the flanks by an angular ventrolateral shoulder. Half a volution earlier, the venter is plane and another half a volution back, the venter is broadly rounded. The sculpture shows significant ontogenetic changes from the subadult stage with 13 coarse and blunt ventrolateral nodes, which originate from weak and rounded radial ribs, per volution. They become weaker and more numerous in the last quarter volution of the phragmocone (about 12 weak ventrolateral nodes within this interval). The body chamber possesses a very weak sculpture consisting only of weak and rounded radial riblets in the inner flank area.

The suture line of the holotype possesses a parallel-sided external lobe with prongs being asymmetrically serrated by four and five small notches, respectively. The asymmetric ventrolateral saddle is nearly as wide as high; it is followed by an adventive lobe with oblique base serrated into seven small notches. The weakly asymmetric, inverted U-shaped lateral saddle is nearly as high as the ventrolateral saddle. Finally, the asymmetric lateral lobe has also seven small notches (Fig. 52A).

The smaller paratype MB.C.29997 has $74 \mathrm{~mm}$ conch diameter, of which the phragmocone has a diameter of $64 \mathrm{~mm}$ and one quarter of a whorl belongs to the body chamber (Fig. 51B). The whorl profile is subtrapezoidal with concave, converging flanks and the venter is weakly concave. The sculpture generally resembles the holotype, but the ribs and nodes are weaker. The same is true for the additional

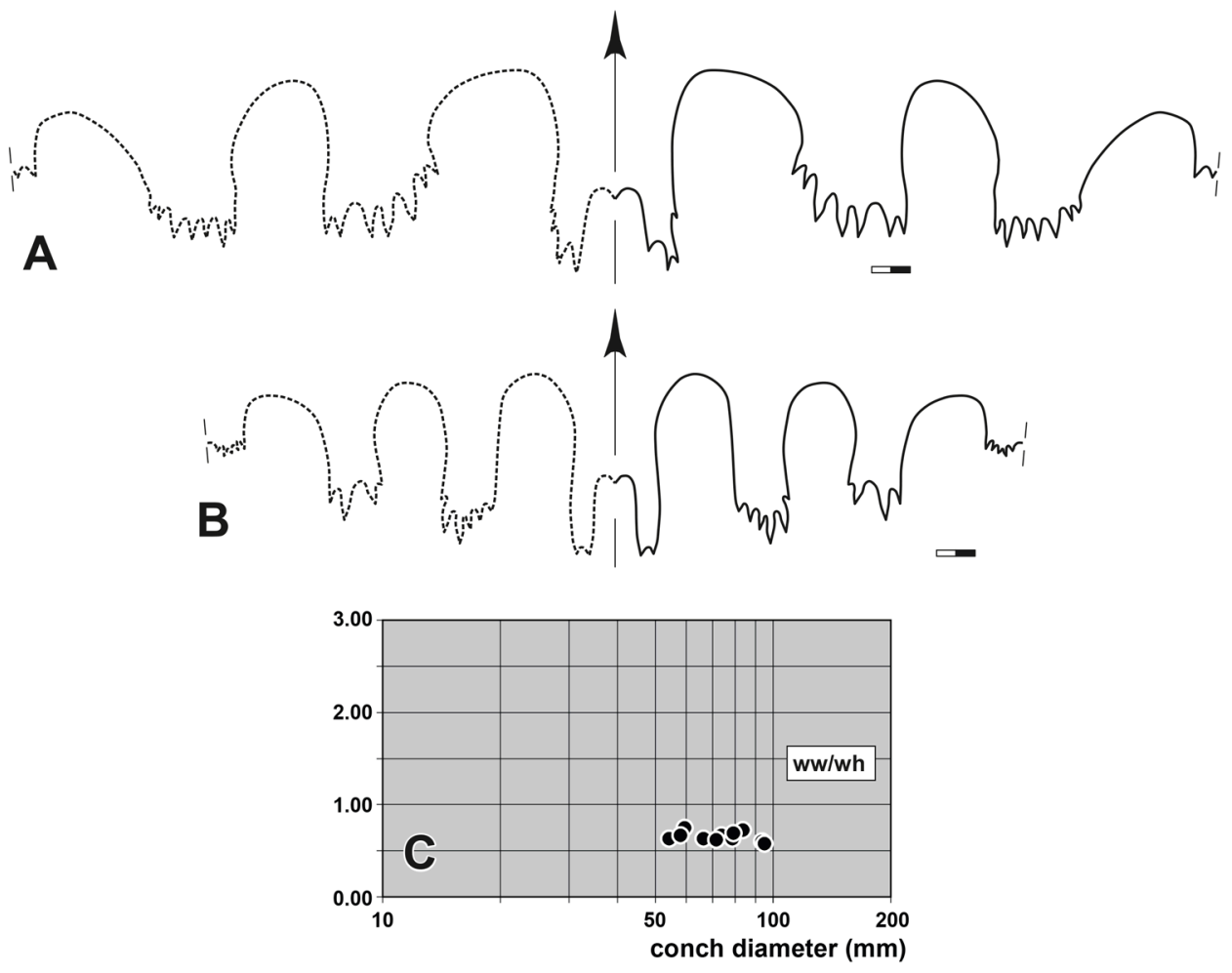

Fig. 52. Lutites lyriformis Korn \& Hairapetian gen. et sp. nov. A. Suture line, holotype MB.C.29995, at $58.3 \mathrm{~mm} \mathrm{dm}, 23.1 \mathrm{~mm}$ wh. B. Suture line, paratype MB.C.29997, at $53.8 \mathrm{~mm} \mathrm{dm}, 19.0 \mathrm{~mm}$ wh. C. Whorl profile proportions. Abbreviations: see Material and methods. Scale bar units $=1 \mathrm{~mm}$. 
Table 26. Conch dimensions (partly estimated) and ratios of selected specimens of Lutites lyriformis Korn \& Hairapetian gen. et sp. nov. from Baghuk Mountain.

\begin{tabular}{ccccccccccc}
\hline Specimen & $\mathbf{d m}$ & ww & wh & uw & ah & ww/dm & ww/wh & uw/dm & WER & IZR \\
\hline MB.C.29995 & 95.8 & 19.9 & 34.6 & 35.8 & 31.7 & 0.21 & 0.58 & 0.37 & 2.23 & 0.08 \\
MB.C.29996 & 94.3 & 18.6 & 31.1 & 41.3 & 30.0 & 0.20 & 0.60 & 0.44 & 2.15 & 0.03 \\
MB.C.29998 & 79.7 & 18.3 & 26.6 & 31.3 & 24.4 & 0.23 & 0.69 & 0.39 & 2.08 & 0.08 \\
MB.C.29999 & 79.2 & 18.0 & 28.6 & 29.3 & 25.5 & 0.23 & 0.63 & 0.37 & 2.18 & 0.11 \\
MB.C.29997 & 74.3 & 16.8 & 25.3 & 30.1 & 24.5 & 0.23 & 0.66 & 0.41 & 2.23 & 0.03 \\
MB.C.29994 & 72.0 & 15.1 & 24.4 & 29.2 & 23.0 & 0.21 & 0.62 & 0.41 & 2.16 & 0.06 \\
MB.C.29995 & 95.8 & 19.9 & 34.6 & 35.8 & 31.7 & 0.21 & 0.58 & 0.37 & 2.23 & 0.08 \\
\hline
\end{tabular}

paratypes MB.C.29996 (Fig. 51C) and MB.C.29999 (Fig. 51D), which is the conch geometry are nearly identical with the holotype.

The suture line of paratype MB.C.29997 shows a parallel-sided external lobe that is deeper than the adventive lobe. The prongs are bifid and parallel-sided. All lobes and thus saddles are parallel-sided and all saddles have the same height. The adventive lobe and the lateral lobe possess six and four small notches (Fig. 52B).

\section{Remarks}

The new species differs in the coarse ventrolateral nodes of the subadult stage from most of the other species of Lutites gen. nov. with compressed whorl profile. Lutites lyriformis gen. et sp. nov. is similar to $L$. profundus gen. et sp. nov. but differs in the much weaker sculpture of the terminal body chamber, which shows only very weak ribs in L. lyriformis gen. et sp. nov. but ventrolateral nodes in L. profundus gen. et sp. nov.

\section{Stratigraphic range}

Upper part of the Hambast Formation; 1.45 to $1.00 \mathrm{~m}$ below the extinction horizon (Lutites profundus Zone to Abichites abichi Zone).

Lutites profundus Korn \& Hairapetian gen. et sp. nov. urn:1sid:zoobank.org:act:BB88C301-E69F-4E4B-8B25-F086D3BC6EEC

Fig. 53; Table 27

\section{Diagnosis}

Species of Lutites gen. nov. with conch reaching $125 \mathrm{~mm} \mathrm{dm}$. Subadult stage with subcircular, compressed whorl profile $(\mathrm{ww} / \mathrm{wh}=0.70-0.80)$ and rounded venter; about 13 coarse ventrolateral nodes per volution. Adult stage with subtrapezoidal, compressed whorl profile (ww/wh $=0.70-0.75)$, flat or concave venter and angular ventrolateral shoulder; weak dorsolateral ribs and elongated ventrolateral nodes. Prongs of external lobe trifid; altogether about 19 notches of E, A and L lobes.

\section{Etymology}

From the Latin 'profundus', meaning 'deep', because of the deep external lobe. 


\section{Material examined}

\section{Holotype}

IRAN - Esfahan Province, Baghuk Mountain E section; Hambast Formation; illustrated in Fig. 53; MB.C.30003.

\section{Paratypes}

IRAN • 1 specimen; Esfahan Province, Baghuk Mountain C section; Hambast Formation; MB.C.30002 • 1 specimen; Esfahan Province, Baghuk Mountain E section; Hambast Formation; MB.C.30004 • 1 specimen; Esfahan Province, Baghuk Mountain G section; Hambast Formation; MB.C.30005 • 3 specimens; Esfahan Province, Baghuk Mountain H section; Hambast Formation; MB.C.30006 to MB.C.30008.

\section{Description}

Holotype MB.C.30003 is a rather well-preserved specimen with $86 \mathrm{~mm}$ conch diameter, in which two whorls can be studied (Fig. 53A). One third of the last volution belongs to the body chamber and the last four septa of the phragmocone are crowded. In the adult stage, the compressed whorl profile (ww/ $w h=0.75$ ) shows a broadly rounded umbilical margin with an oblique umbilical wall. The whorl profile is widest on the inner flank, from where the concave flanks converge towards the angular ventrolateral
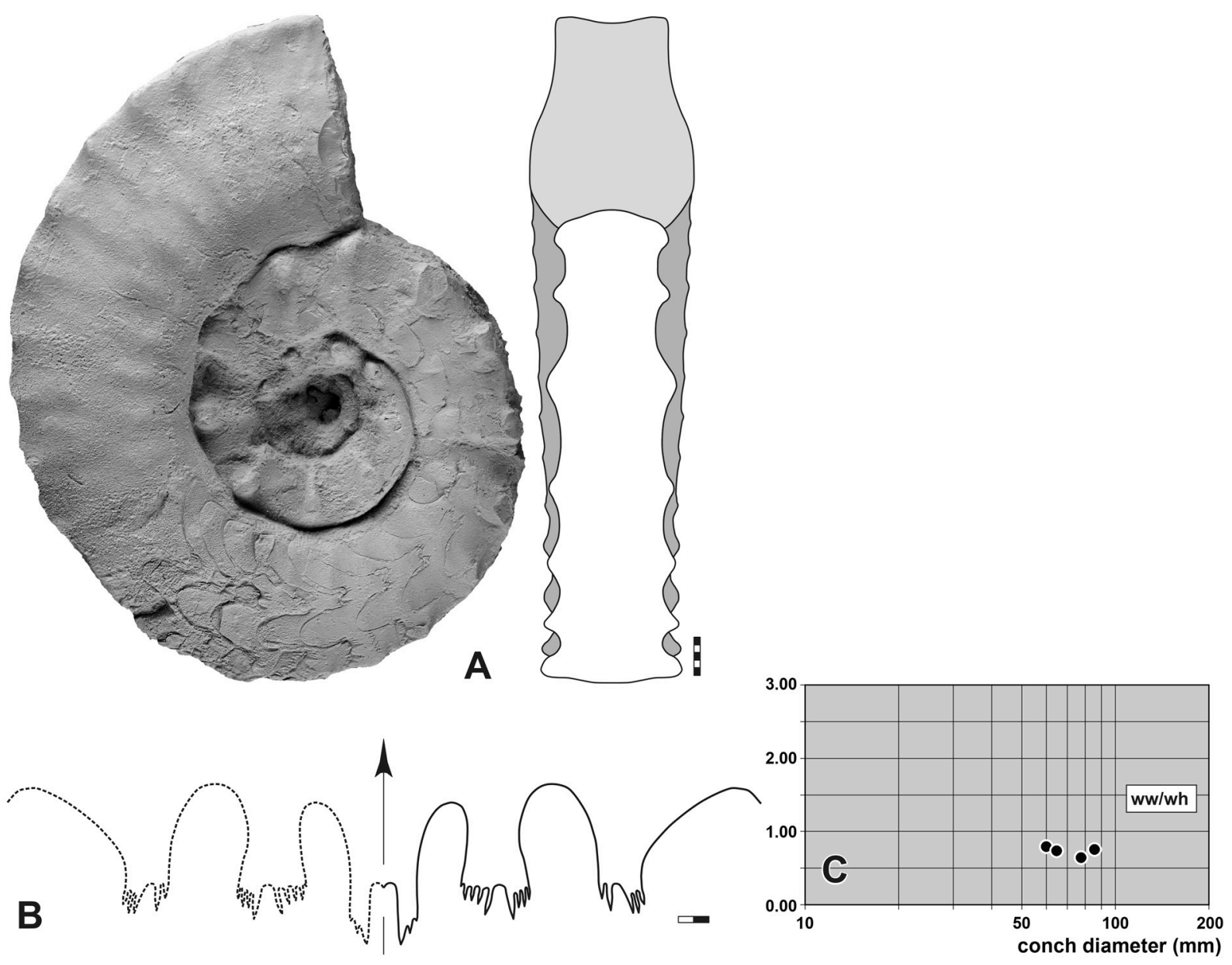

Fig. 53. Lutites profundus Korn \& Hairapetian gen. et sp. nov. A. Lateral and dorsal view, holotype MB.C.30003, section E, float. B. Suture line, holotype MB.C.30003, at $60.0 \mathrm{~mm} \mathrm{dm}, 19.6 \mathrm{~mm}$ wh. C. Whorl profile proportions. Abbreviations: see Material and methods. Scale bar units $=1 \mathrm{~mm}$. 
Table 27. Conch dimensions (partly estimated) and ratios of selected specimens of Lutites profundus Korn \& Hairapetian gen. et sp. nov. from Baghuk Mountain.

\begin{tabular}{ccccccccccc}
\hline Specimen & dm & ww & wh & uw & ah & ww/dm & ww/wh & uw/dm & WER & IZR \\
\hline MB.C.30005 & 95.0 & - & 32.0 & 40.4 & 30.5 & - & - & 0.43 & 2.17 & 0.05 \\
MB.C.30005 & 65.0 & 16.5 & 22.5 & 27.3 & - & 0.25 & 0.73 & 0.42 & - & - \\
MB.C.30003 & 86.2 & 21.2 & 28.2 & 37.8 & 27.7 & 0.25 & 0.75 & 0.44 & 2.17 & 0.02 \\
MB.C.30003 & 60.2 & 16.2 & 20.5 & 24.8 & - & 0.27 & 0.79 & 0.41 & - & - \\
MB.C.30002 & 78.0 & 18.0 & 28.0 & 33.0 & - & 0.23 & 0.64 & 0.42 & - & - \\
\hline
\end{tabular}

shoulder. The venter is concave in this growth stage. Half a volution back the venter is flat and another half whorl back, a rounded venter can be seen belonging to a subcircular, compressed whorl section $(\mathrm{ww} / \mathrm{wh}=0.80)$. The sculpture experiences a change in strength during the last volution. The penultimate volution has ten coarse ventrolateral nodes, which are connected with weak and rounded radial ribs. These nodes become weaker and more numerous at the end of the phragmocone, but they are still present on the body chamber (12 on a distance of 120 degrees). Here, they are elongate and alternate, in their positions, with low umbilical ribs.

The suture line of the holotype has a narrow and deep external lobe (deeper than the adventive lobe) with parallel flanks in the lower part. Its prongs are parallel-sided with asymmetric base and possesses three small notches. The ventrolateral saddle is narrow and asymmetric; it borders the adventive lobe that is widest near its base. It shows two groups of five very narrow notches. The nearly symmetric and inverted U-shaped lateral saddle is higher than the ventrolateral saddle. The asymmetric lateral lobe with less steep dorsal flank has also two groups of narrow notches, a ventral group with two and a dorsal group with three notches (Fig. 53B).

\section{Remarks}

Lutites profundus gen. et sp. nov. is similar to L. lyriformis gen. et sp. nov. but differs in the much coarser sculpture of the terminal body chamber, which shows only very weak ribs in the latter species but ventrolateral nodes in L. profundus gen. et sp. nov. All the other species of Lutites gen. nov. with a slender conch also show a much weaker sculpture.

\section{Stratigraphic range}

Upper part of the Hambast Formation; 1.60 to 1.20 m below the extinction horizon (Lutites profundus Zone).

Lutites alius Korn \& Hairapetian gen. et sp. nov. urn:lsid:zoobank.org:act:393BE629-C3CF-4FED-A221-1FFD673C8636

Fig. 54, Table 28

\section{Diagnosis}

Species of Lutites gen. nov. with conch reaching $130 \mathrm{~mm} \mathrm{dm}$. Subadult stage with oval, compressed whorl profile $(\mathrm{ww} / \mathrm{wh}=0.60-0.70)$ and rounded venter; very weak, rounded ribs. Adult stage with subtrapezoidal, compressed whorl profile $(\mathrm{ww} / \mathrm{wh}=0.50-0.60)$, flat or concave venter and angular ventrolateral shoulder; very weak ribs. Prongs of external lobe simple; altogether about 17 notches of E, A and L lobes. 


\section{Etymology}

From the Latin 'alius', meaning 'different', because of the different notching degree of the external and adventive lobes.

\section{Material examined}

\section{Holotype}

IRAN • Esfahan Province, Baghuk Mountain E section; Hambast Formation; illustrated in Fig. 54A; MB.C.30013.

\section{Paratypes}

IRAN • 2 specimens; Esfahan Province, Baghuk Mountain 1 section; Hambast Formation; MB.C.30009 to MB.C.30010 - 1 specimen; Esfahan Province, Baghuk Mountain A section; Hambast Formation; MB.C.30011 - 1 specimen; Esfahan Province, Baghuk Mountain B section; Hambast Formation; MB.C.30012 - 2 specimens; Esfahan Province, Baghuk Mountain E section; Hambast Formation;
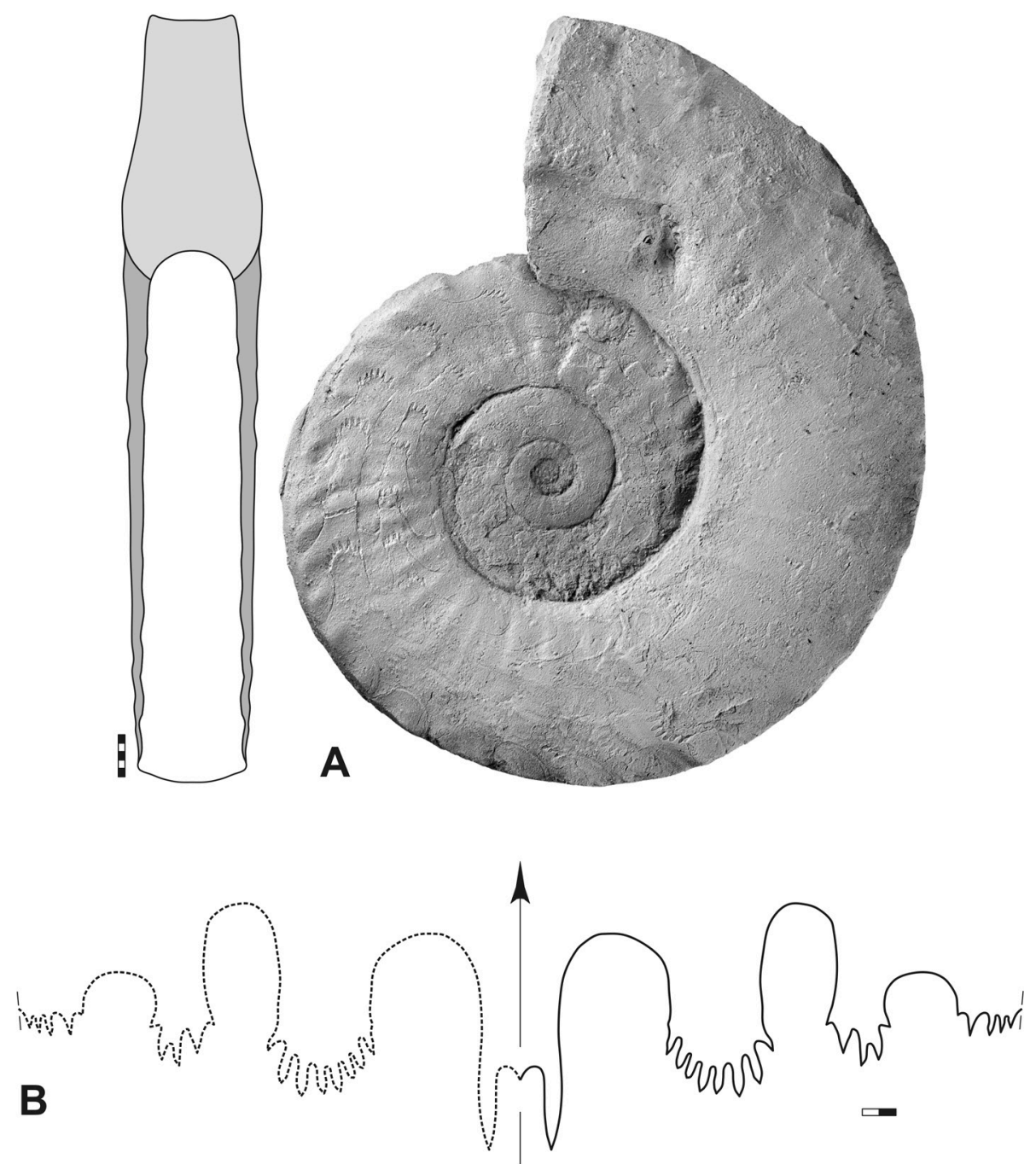

Fig. 54. Lutites alius Korn \& Hairapetian gen. et sp. nov. A. Lateral and dorsal view, holotype specimen MB.C.30013, section E, float. B. Suture line, specimen MB.C.30013, at $64.3 \mathrm{~mm} \mathrm{dm}, 13.5 \mathrm{~mm} w w$, $22.6 \mathrm{~mm}$ wh. Abbreviations: see Material and methods. Scale bar units $=1 \mathrm{~mm}$. 
Table 28. Conch dimensions (partly estimated) and ratios of the holotype of Lutites alius Korn \& Hairapetian gen. et sp. nov. from Baghuk Mountain.

\begin{tabular}{ccccccccccc}
\hline Specimen & dm & ww & wh & uw & ah & ww/dm & ww/wh & uw/dm & WER & IZR \\
\hline MB.C.30013 & 90.5 & 17.0 & 30.5 & 36.5 & 28.4 & 0.19 & 0.56 & 0.40 & 2.12 & 0.07 \\
MB.C.30013 & 64.4 & 15.0 & 22.5 & 25.1 & - & 0.23 & 0.67 & 0.39 & - & - \\
\hline
\end{tabular}

MB.C.30014 to MB.C.30015 - 2 specimens; Esfahan Province, Baghuk Mountain G section; Hambast Formation; MB.C.30016 to MB.C.30017.

\section{Description}

Holotype MB.C.30013 has a conch diameter of $90 \mathrm{~mm}$ and allows the study of three and a half volutions (Fig. 54A). Less than half of the last whorl belongs to the body chamber. The conch is very slender (ww/ $\mathrm{dm}=0.19)$ with a compressed whorl profile $(\mathrm{ww} / \mathrm{wh}=0.55)$ that shows a concave venter bordered by an angular ventrolateral shoulder from the concave, converging flanks. One volution back, the compressed whorl profile is oval with rounded venter. The shell ornament does not change significantly during the last three volutions. It consists of fine, weakly sigmoidal ribs that are best visible on the inner flank and the ventrolateral margin, where they develop into weak nodes. These nodes disappear on the terminal body chamber.

The suture line of the holotype has a very narrow, parallel-sided and very deep (1.5 times of the adventive lobe) external lobe with very narrow, lanceolate and unsubdivided prongs. Both flanks of the inverted U-shaped ventrolateral saddle are parallel, and also the adventive and lateral lobes are parallel-sided. The adventive lobe has a semicircular base with eight small notches and the lateral lobe bears five notches (Fig. 54B).

\section{Remarks}

Lutites alius gen. et sp. nov. differs in the simple (non-subdivided prongs) and very deep external lobe from the other species of the genus. Furthermore, it lacks coarse ornament and possesses a very slender conch, which make a separation from other species easy.

\section{Stratigraphic range}

Upper part of the Hambast Formation; 1.70 to $1.20 \mathrm{~m}$ below the extinction horizon (Lutites profundus Zone).

Lutites plicatus Korn \& Hairapetian gen. et sp. nov. urn:1sid:zoobank.org:act:1713B70A-3C3C-4FCD-9827-BBBA6F989797

Fig. 55; Table 29

\section{Diagnosis}

Species of Lutites gen. nov. with conch reaching $120 \mathrm{~mm} \mathrm{dm}$. Subadult stage with oval, compressed whorl profile $(\mathrm{ww} / \mathrm{wh}=0.75)$ and rounded venter; about 12 radial plications per volution. Adult stage with subtrapezoidal, compressed whorl profile $(\mathrm{ww} / \mathrm{wh}=0.72)$, weakly concave flanks, flattened venter and subangular ventrolateral shoulder; numerous weak and densely arranged plications and small ventrolateral nodes. Prongs of external lobe multiply serrated; altogether 20 notches of E, A and L lobes. 


\section{Etymology}

From the Latin 'plicatus', meaning 'corrugated', referring to the dense ribbing.

\section{Material examined}

\section{Holotype}

IRAN - Esfahan Province, Baghuk Mountain E section; Hambast Formation; illustrated in Fig. 55A; MB.C.30018.

\section{Description}

Holotype MB.C. 30018 is a specimen with $84 \mathrm{~mm}$ diameter, of which the last 120 degrees belong to the body chamber (Fig. 55A). Nearly one volution of the phragmocone can be studied; at this stage the whorl profile is oval and compressed with a rounded venter. The ornament consists of nearly 20 faint radial plications, which are coarsest near the umbilicus and in the ventrolateral area, where they form weak nodes. The ornament is weaker on the body chamber, where the plications are more numerous. The whorl profile is subtrapezoidal and compressed $(\mathrm{ww} / \mathrm{wh}=0.72)$ in the adult stage with a rounded umbilical margin, weakly concave flanks and a flattened venter.
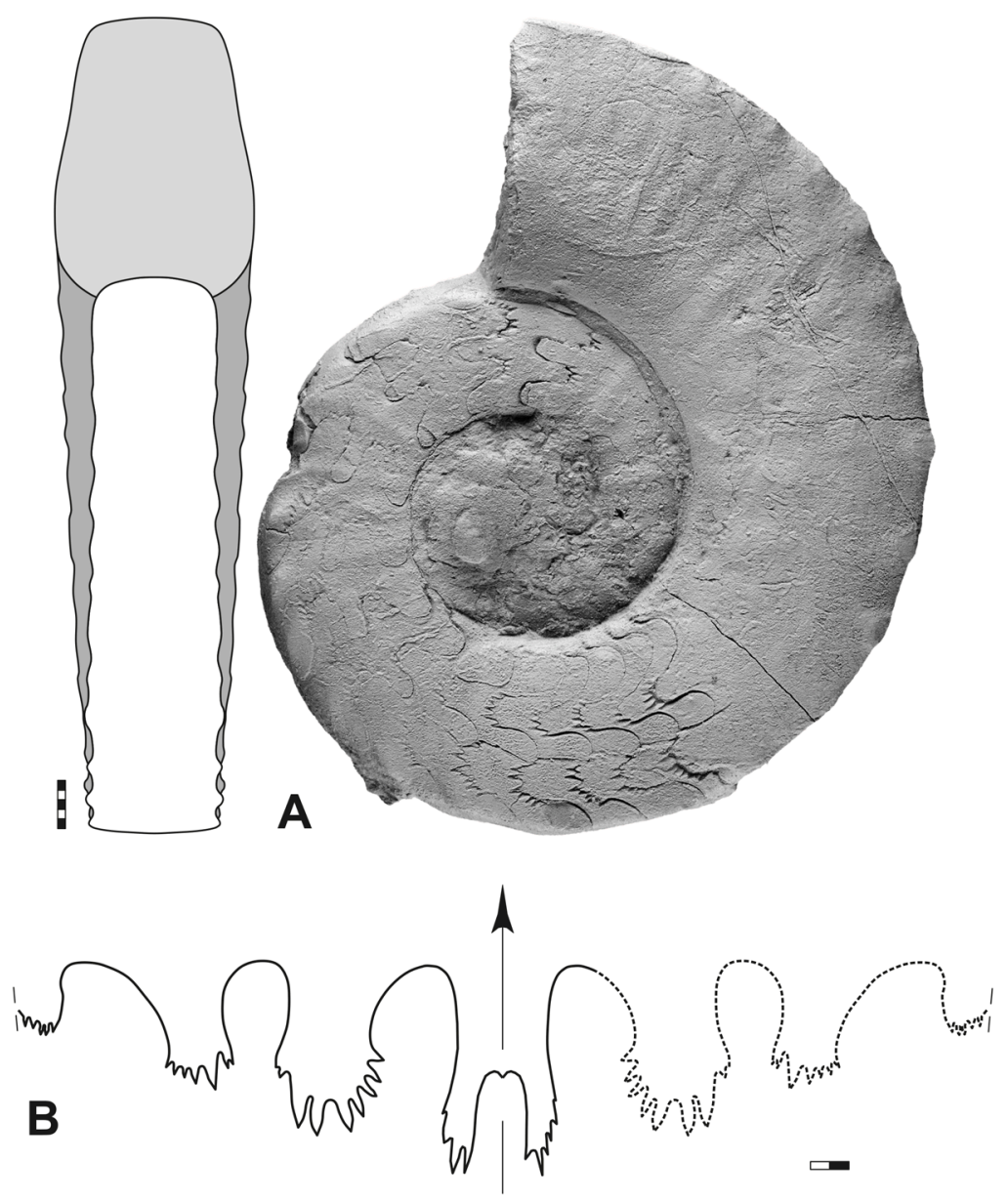

Fig. 55. Lutites plicatus Korn \& Hairapetian gen. et sp. nov. A. Lateral and dorsal view, holotype MB.C.30018, section E, float. B. Suture line, holotype MB.C.30018, $13.7 \mathrm{~mm}$ ww, $18.6 \mathrm{~mm}$ wh. Abbreviations: see Material and methods. Scale bar units $=1 \mathrm{~mm}$. 
Table 29. Conch dimensions (partly estimated) and ratios of the holotype of Lutites plicatus Korn \& Hairapetian gen. et sp. nov. from Baghuk Mountain.

\begin{tabular}{ccccccccccc}
\hline Specimen & $\mathbf{d m}$ & ww & wh & uw & ah & ww/dm & ww/wh & uw/dm & WER & IZR \\
\hline MB.C.30018 & 84.3 & 20.7 & 28.7 & 34.5 & 26.7 & 0.25 & 0.72 & 0.41 & 2.14 & 0.07 \\
MB.C.30018 & 59.7 & 15.3 & 20.5 & 23.2 & - & 0.26 & 0.75 & 0.39 & - & - \\
\hline
\end{tabular}

The suture line of the holotype has a narrow external lobe with asymmetric, multiply serrated prongs (four and six small notches), an asymmetric and inflated ventrolateral saddle and multiply serrated adventive and lateral lobes (Fig. 55B). Both lobes show notches of various size.

\section{Remarks}

Lutites plicatus gen. et sp. nov. differs in the shape of the flattened, but convex venter from most of the other species of the genus (L. lyriformis gen. et sp. nov., L. profundus gen. et sp. nov., L. alius gen. et sp. nov.), which possess a completely flat or even concave venter.

\section{Stratigraphic range}

Upper part of the Hambast Formation; horizon unknown.

\section{Genus Abichites Shevyrev, 1965}

\section{Type species}

Kashmirites? stoyanowi Kiparisova in Voinova et al., 1947, by original designation.

\section{Included species}

Abichites abichi Shevyrev, 1965; Abichites alibashiensis Korn \& Ghaderi in Korn et al., 2016; Abichites ariaeii Korn \& Ghaderi in Korn et al., 2016; Abichites paucinodus Korn \& Ghaderi in Korn et al., 2016; Abichites shahriari Korn \& Ghaderi in Korn et al., 2016; Kashmirites? stoyanowi Kiparisova in Voinova et al., 1947; Abichites subtrapezoidalis Korn \& Ghaderi in Korn et al., 2016; Abichites terminalis Korn \& Ghaderi in Korn et al., 2016; Abichites ovalis Korn \& Hairapetian sp. nov.; Abichites infirmus Korn \& Hairapetian sp. nov.

\section{Diagnosis}

Genus of the family Dzhulfitidae with small to moderately large conch; maximum adult diameters are between 30 and $90 \mathrm{~mm}$. Adult stage with quadrate, rectangular or oval whorl profile. Subadult stage with weak to moderately strong lateral ribs; adult stage with weak ornament. Suture line with deep external lobe; the depths of external lobe and adventive lobe are nearly identical.

\section{Remarks}

The morphological range of the genus Abichites was discussed by Korn \& Ghaderi (in Korn et al. 2016).

Abichites abichi Shevyrev, 1965

Fig. 56; Table 30

Abichites abichi Shevyrev, 1965: 181, pl. 24 fig. 4.

Xenodiscus aff. kapila - Stoyanow 1910: 87, pl. 9 fig. 3. 
Abichites abichi - Shevyrev 1968: 96, pl. 4 fig. 4. - Korn \& Ghaderi in Korn et al. 2016: 878, textfig. 35 .

\section{Diagnosis}

Species of Abichites with conch reaching $75 \mathrm{~mm} \mathrm{dm}$. Subadult stage with subquadrate, weakly depressed to compressed whorl profile $(\mathrm{ww} / \mathrm{wh}=1.20)$ and slightly flattened venter; with 15 rounded straight ribs on the flanks. Adult stage with quadrate whorl profile $(\mathrm{ww} / \mathrm{wh}=1.00)$, parallel flanks and flattened venter; with weak rounded ribs on the flanks. Prongs of external lobe usually simple; 7-12 notches of E, A and L lobes.

\section{Type material}

\section{Holotype}

AZERBAIJAN • Nakhichevan Province, Dorasham 2 section; Paratirolites Limestone; illustrated by Shevyrev (1965: pl. 24 fig. 4); PIN 1252/137.

\section{Material examined}

IRAN • 4 specimens; Esfahan Province, Baghuk Mountain 1 section; Hambast Formation; MB.C.30019 to MB.C.30022 - 1 specimen; Esfahan Province, Baghuk Mountain B section; Hambast Formation; MB.C.30023 - 5 specimens; Esfahan Province, Baghuk Mountain C section; Hambast Formation; MB.C.30024 to MB.C.30028 • 6 specimens; Esfahan Province, Baghuk Mountain C section; Hambast Formation; MB.C.30029 to MB.C.30034 - 4 specimens; Esfahan Province, Baghuk Mountain G section; Hambast Formation; MB.C.30035 to MB.C.30038 • 2 specimens; Esfahan Province, Baghuk Mountain H section; Hambast Formation; MB.C.30039 to MB.C.30040.
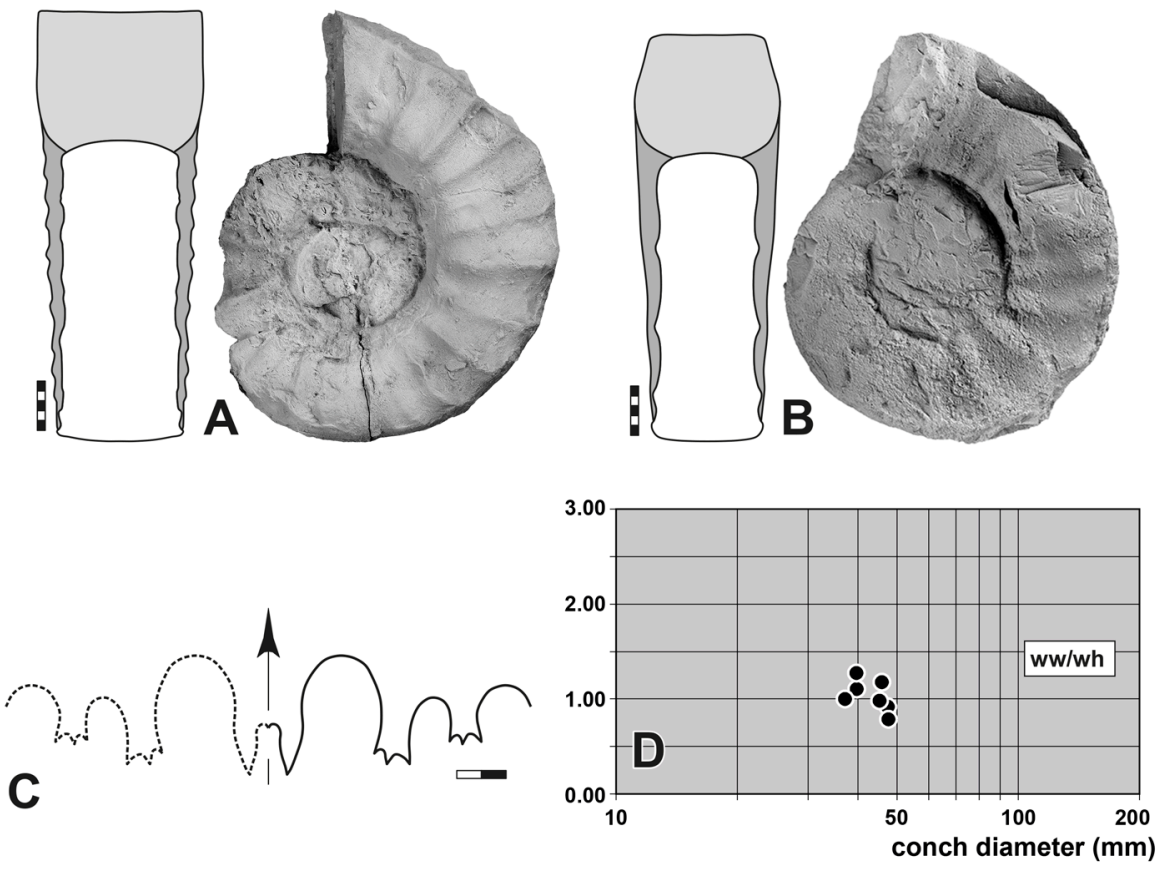

Fig. 56. Abichites abichi Shevyrev, 1965. A. Lateral and dorsal view, specimen MB.C.30039, section H, $-1.30 \mathrm{~m}$. B. Lateral and dorsal view, specimen MB.C.30019, section 1, $-0.90 \mathrm{~m}$. C. Suture line, specimen MB.C.30019, at $7.7 \mathrm{~mm}$ wh. D. Whorl profile proportions. Abbreviation: see Material and methods. Scale bar units $=1 \mathrm{~mm}$. 
Table 30. Conch dimensions (partly estimated) and ratios of the holotype of Abichites abichi Shevyrev, 1965 from Baghuk Mountain.

\begin{tabular}{ccccccccccc}
\hline Specimen & dm & ww & wh & uw & ah & ww/dm & ww/wh & uw/dm & WER & IZR \\
\hline MB.C.30019 & 39.8 & 14.4 & 13.1 & 16.3 & 12.7 & 0.36 & 1.10 & 0.41 & 2.16 & 0.03 \\
MB.C.30028 & 47.7 & 12.2 & 15.6 & 20.0 & 15.0 & 0.26 & 0.78 & 0.42 & 2.13 & 0.04 \\
MB.C.30027 & 47.6 & 15.7 & 17.2 & 19.7 & 16.5 & 0.33 & 0.91 & 0.41 & 2.34 & 0.04 \\
MB.C.30023 & 46.0 & 18.9 & 16.2 & 20.2 & 15.2 & 0.41 & 1.17 & 0.44 & 2.23 & 0.06 \\
MB.C.30038 & 45.4 & 14.6 & 15.0 & 18.9 & 14.0 & 0.32 & 0.97 & 0.42 & 2.09 & 0.07 \\
MB.C.30036 & 37.2 & 12.3 & 12.4 & 15.7 & 11.6 & 0.33 & 0.99 & 0.42 & 2.11 & 0.06 \\
\hline
\end{tabular}

\section{Description}

Specimen MB.C.30039 has $44 \mathrm{~mm}$ diameter and is a fragment of half a volution (Fig. 56A). However, it allows the study of the conch shape with a nearly quadrate whorl profile. On half of a volution there are twelve sharp radial ribs, which are coarsest in the outer flank.

Specimen MB.C.30019 has $40 \mathrm{~mm}$ conch diameter and allows the study of only one volution (Fig. 56B). The whorl profile is subtrapezoidal with broadly rounded umbilical margin, weakly converging flanks, a subangular ventrolateral shoulder and a flat venter. The sculpture is weaker than in the first specimen and the ribs are coarsest on the inner flank.

The suture line of specimen MB.C.30019 is characterised by a large external lobe, of which the flanks stand parallel in the middle part. Its prongs are narrowly V-shaped and non-serrated. After a ventrolateral saddle that is as wide as the external lobe follow a small, nearly parallel-sided adventive lobe with three notches, a small lateral saddle and a small parallel-sided lateral lobe with three notches (Fig. 56C).

\section{Remarks}

Abichites abichi differs from the otherwise similar species $A$. subtrapezoidalis in the quadrate adult whorl profile (subtrapezoidal in A. subtrapezoidalis). The body chamber of $A$. abichi has stronger ribs than A. subtrapezoidalis does. A. alibashiensis has a similar body chamber, but differs from A. abichi in the coarse ventrolateral nodes of the subadult stage.

\section{Stratigraphic range}

Upper part of the Hambast Formation; 1.20 to $0.05 \mathrm{~m}$ below the extinction horizon (Abichites abichi Zone to Arasella minuta Zone).

Abichites alibashiensis Korn \& Ghaderi in Korn et al., 2016

Fig. 57; Table 31

Abichites alibashiensis Korn \& Ghaderi in Korn et al., 2016: 879, text-fig. 36.

\section{Diagnosis}

Species of Abichites with conch reaching $85 \mathrm{~mm} \mathrm{dm}$. Subadult stage with broadly oval, weakly depressed whorl profile (ww/wh $=1.10-1.30)$ and rounded venter; $12-15$ ventrolateral nodes per volution. Adult stage with quadrate of weakly subtrapezoidal, weakly compressed whorl profile (ww/wh $=0.80-1.25$ ), 
flattened venter and subangular to angular ventrolateral shoulder; sharp ribs. Prongs of external lobe simple or bifid; altogether 7-11 notches of E, A and L lobes.

\section{Material examined}

\section{Holotype}

IRAN • East Azerbaijan, Ali Bashi N section; Paratirolites Limestone, $1.40 \mathrm{~m}$ below the top; illustrated by Korn \& Ghaderi in Korn et al. (2016: text-fig. 36a); MB.C.25399.

\section{Additional material}

IRAN • 2 specimens; Esfahan Province, Baghuk Mountain 1 section; Hambast Formation; MB.C.30041 to MB.C.30042 - 3 specimens; Esfahan Province, Baghuk Mountain B section; Hambast Formation; MB.C.30043 to MB.C.30045 - 3 specimens; Esfahan Province, Baghuk Mountain C section; Hambast Formation; MB.C.30046 to MB.C.30048 • 5 specimens; Esfahan Province, Baghuk Mountain E section; Hambast Formation; MB.C.30049 to MB.C.30053 • 1 specimen; Esfahan Province, Baghuk Mountain F section; Hambast Formation; MB.C.30054 • 4 specimens; Esfahan Province, Baghuk Mountain G section; Hambast Formation; MB.C.30055 to MB.C.30058.
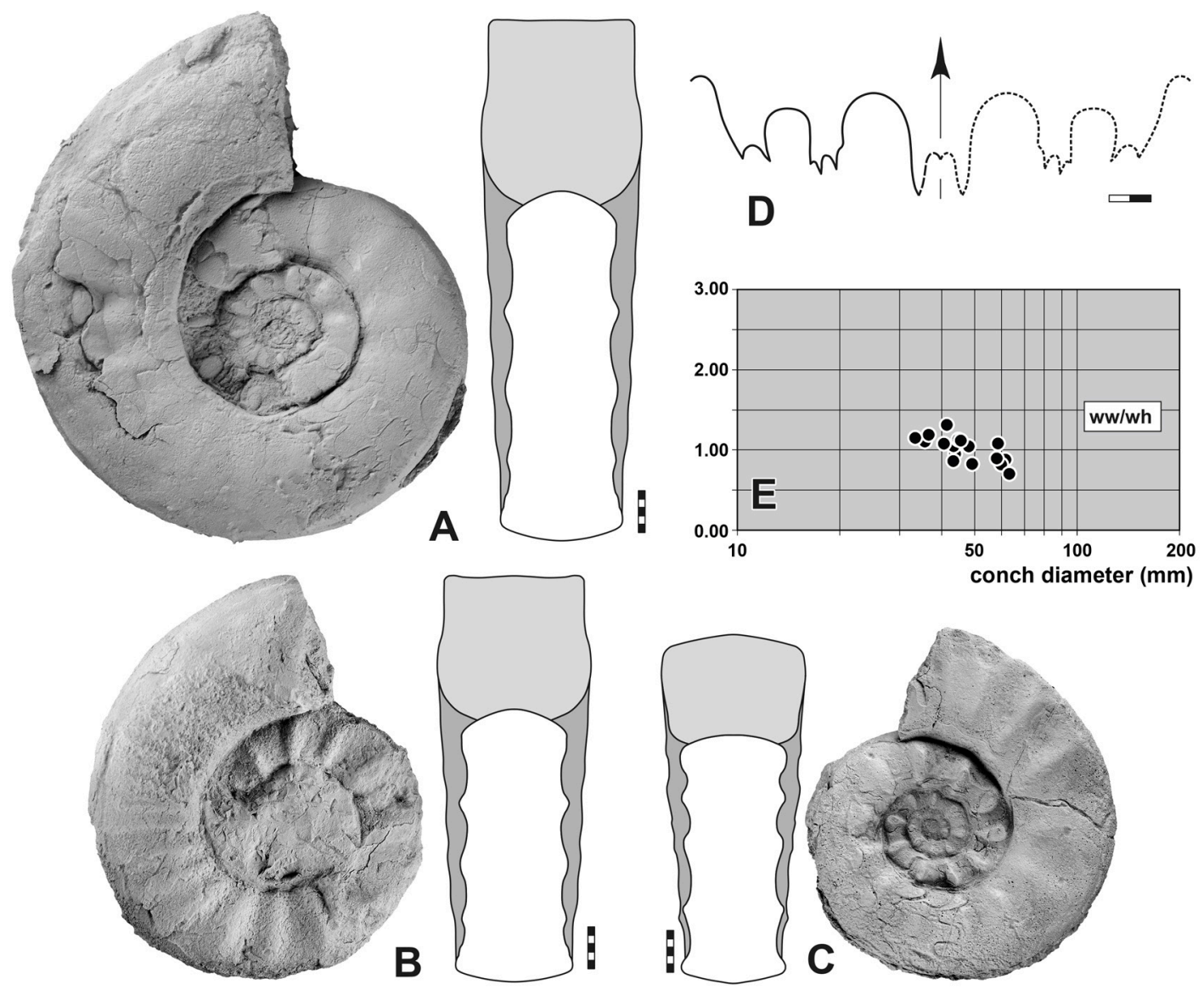

Fig. 57. Abichites alibashiensis Korn \& Ghaderi, 2016. A. Lateral and dorsal view, specimen MB.C.30051, section E, float. B. Lateral and dorsal view, specimen MB.C.30046, section C, $-0.50 \mathrm{~m}$. C. Lateral and dorsal view, specimen MB.C.30045, section B, float. D. Suture line, specimen MB.C.30046, at $10.1 \mathrm{~mm}$ wh. E. Whorl profile proportions. Abbreviation: see Material and methods. Scale bar units $=1 \mathrm{~mm}$. 
KORN D. et al., Ammonoids from Baghuk Mountain

Table 31. Conch dimensions (partly estimated) and ratios of selected specimens of Abichites alibashiensis Korn \& Ghaderi in Korn et al. (2016) from Baghuk Mountain.

\begin{tabular}{ccccccccccc}
\hline Specimen & $\mathbf{d m}$ & $\mathbf{w w}$ & $\mathbf{w h}$ & $\mathbf{u w}$ & $\mathbf{a h}$ & $\mathbf{w w} / \mathbf{d m}$ & $\mathbf{w w} / \mathbf{w h}$ & $\mathbf{u w} / \mathbf{d m}$ & WER & IZR \\
\hline MB.C.30051 & 61.9 & 18.8 & 21.5 & 25.6 & 20.2 & 0.30 & 0.87 & 0.41 & 2.20 & 0.06 \\
MB.C.30046 & 48.2 & 17.2 & 16.6 & 19.4 & 15.9 & 0.36 & 1.04 & 0.40 & 2.23 & 0.04 \\
MB.C.30049 & 43.5 & 15.3 & 14.7 & 17.2 & 14.0 & 0.35 & 1.04 & 0.40 & 2.17 & 0.05 \\
MB.C.30045 & 41.5 & 17.1 & 13.2 & 17.3 & 12.8 & 0.41 & 1.30 & 0.42 & 2.09 & 0.03 \\
MB.C.30048 & 36.7 & 14.4 & 12.2 & 16.5 & 11.8 & 0.39 & 1.18 & 0.45 & 2.17 & 0.03 \\
MB.C.30047 & 63.5 & 15.8 & 22.6 & 24.4 & 21.8 & 0.25 & 0.70 & 0.38 & 2.32 & 0.04 \\
MB.C.30057 & 60.1 & 18.0 & 22.1 & 22.5 & 20.9 & 0.30 & 0.81 & 0.37 & 2.35 & 0.05 \\
MB.C.30058 & 58.8 & 20.4 & 19.0 & 24.2 & 18.8 & 0.35 & 1.07 & 0.41 & 2.16 & 0.01 \\
MB.C.30041 & 58.3 & 15.8 & 17.8 & 24.2 & 16.8 & 0.27 & 0.89 & 0.42 & 1.97 & 0.06 \\
MB.C.30050 & 45.7 & 17.4 & 15.7 & 18.9 & 15.0 & 0.38 & 1.11 & 0.41 & 2.22 & 0.04 \\
MB.C.30052 & 43.4 & 13.0 & 15.2 & 18.5 & 14.5 & 0.30 & 0.86 & 0.43 & 2.26 & 0.05 \\
MB.C.30043 & 33.5 & 14.6 & 12.8 & 15.2 & 12.1 & 0.44 & 1.14 & 0.45 & 2.45 & 0.05 \\
\hline
\end{tabular}

\section{Description}

Specimen MB.C.30051 has $62 \mathrm{~mm}$ conch diameter and is rather well preserved with about 190 degrees of the body chamber visible (Fig. 57A). The whorl profile of the terminal body chamber has a broadly rounded umbilical margin, weakly concave flanks that are gently converging towards the flat venter, which is deliminated by an angular ventrolateral shoulder. In the phragmocone, the whorl profile is oval with a broadly rounded venter. The change of the sculpture from the subadult stage with coarse ventrolateral nodes (12 per volution) towards the adult stage with only weak ribs on the flank happens already before the beginning of the terminal body chamber.

Specimen MB.C.30046 is smaller (48 $\mathrm{mm} \mathrm{dm}$ ) and shows the transformation from the subadult stage with rounded ventrolateral margin to the adult stage with quadrate whorl profile, in which the venter is flat and separated from the flanks by an angular margin (Fig. 57B). The sculpture of the subadult stage possesses prominent ribs (about 13 per volution), which weaken out on the terminal body chamber. The suture line of specimen MB.C.30046 shows a simply subdivided external lobe with narrow, V-shaped prongs, a broadly rounded parabolic ventrolateral saddle and asymmetric, weakly serrated adventive and lateral lobes (Fig. 57D).

\section{Remarks}

Abichites alibashiensis differs from A. abichi, A. stoyanowi and A. subtrapezoidalis in the sharp ribs, which tend to end in ventrolateral nodes, in the subadult stage. Species of Alibashites possess subadult ribs but also ventrolateral nodes; these are $A$. mojsisovicsi (with very weak adult ribs) and A. ferdowsii (with a much more depressed whorl profile).

\section{Stratigraphic range}

Upper part of the Hambast Formation; 1.15 to 0.40 m below the extinction horizon (Abichites abichi Zone to lowest part of the Arasella minuta Zone). 


\section{Abichites ovalis Korn \& Hairapetian sp. nov. urn:1sid:zoobank.org:act:983F405A-033F-49EB-8D75-E5F917F23D86}

Fig. 58; Table 32

\section{Diagnosis}

Species of Abichites with conch reaching $85 \mathrm{~mm} \mathrm{dm}$. Subadult stage with subcircular, weakly compressed whorl profile $(\mathrm{ww} / \mathrm{wh}=0.80-1.00)$ and rounded venter; about 12 shallow and rounded radial ribs. Adult stage with parallel sided or weakly trapezoidal, weakly compressed whorl profile (ww/wh $=0.80-1.00$ ), rounded venter and narrowly rounded ventrolateral shoulder; shallow wide ribs on the flank. Prongs of external lobe simple; altogether 7-11 notches of E, A and L lobes.

\section{Etymology}

From the Latin 'ovalis', meaning 'oval', because of the oval whorl profile in the subadult stage.

\section{Material examined}

\section{Holotype}

IRAN • Esfahan Province, Baghuk Mountain B section; Hambast Formation; illustrated in Fig. 58A; MB.C.30059.

\section{Paratypes}

IRAN • 1 specimen; Esfahan Province, Baghuk Mountain B section; Hambast Formation; MB.C.30060 • 3 specimens; Esfahan Province, Baghuk Mountain C section; Hambast Formation; MB.C.30061 to MB.C.30063 - 6 specimens; Esfahan Province, Baghuk Mountain E section; Hambast Formation; MB.C.30064 to MB.C.30069 - 2 specimens; Esfahan Province, Baghuk Mountain G section; Hambast Formation; MB.C.30070 to MB.C.30071 • 1 specimen; Esfahan Province, Baghuk Mountain H section; Hambast Formation; MB.C.30072.

\section{Description}

Holotype MB.C.30059 is a rather well-preserved specimen with $62 \mathrm{~mm}$ conch diameter; the phragmocone diameter is $44 \mathrm{~mm}$ and 190 degrees of the body chamber are preserved (Fig. 58A). The adult whorl profile is weakly trapezoidal with gently diverging, slightly concave flanks, a rounded ventrolateral shoulder and a slightly flattened but broadly rounded venter. One volution earlier, the whorl profile is subcircular and weakly compressed $(\mathrm{ww} / \mathrm{wh}=0.90)$. The sculpture on the phragmocone consists of 12 shallow and rounded radial ribs per volution. They become weaker on the body chamber but develop to elongate, rather sharp nodes on the outer flank.

The suture line of holotype MB.C.30059 shows an external lobe with flanks standing parallel in the lower part and diverging in the upper part. The prongs are very narrow, lanceolate and not secondarily serrated. On the outer flank lies the symmetric adventive lobe with semicircular, strongly serrated base; it is followed by a rather high lateral saddle and a parallel-sided lateral lobe with five small notches (Fig. 58C).

Paratype MB.C.30071 has $60 \mathrm{~mm}$ conch diameter and is, with its weakly trapezoidal whorl profile and the general conch shape very similar to the previous one but has a more slender conch $(\mathrm{ww} / \mathrm{wh}=0.85)$. It shows, in the inner whorls, weak ventrolateral nodes connected to the shallow radial ribs (Fig. 58B).

\section{Remarks}

Abichites ovalis sp. nov. closely resembles A. paucinodum, but differs in the whorl profile (diverging flanks in A. ovalis sp. nov. but converging in A. paucinodum), the wider umbilicus in A. ovalis sp. nov. and in the rounded venter in A. ovalis sp. nov. (flat in A. paucinodum). 
Table 32. Conch dimensions (partly estimated) and ratios of selected specimens of Abichites ovalis Korn \& Hairapetian sp. nov. from Baghuk Mountain.

\begin{tabular}{ccccccccccc}
\hline Specimen & $\mathbf{d m}$ & ww & wh & uw & ah & ww/dm & ww/wh & uw/dm & WER & IZR \\
\hline MB.C.30059 & 61.8 & 18.1 & 20.4 & 26.0 & 19.5 & 0.29 & 0.89 & 0.42 & 2.13 & 0.04 \\
MB.C.30071 & 59.5 & 16.3 & 19.7 & 25.5 & 18.7 & 0.27 & 0.83 & 0.43 & 2.13 & 0.05 \\
MB.C.30061 & 42.8 & 14.1 & 14.7 & 16.5 & 14.1 & 0.33 & 0.95 & 0.39 & 2.22 & 0.04 \\
MB.C.30060 & 48.8 & 14.5 & 18.1 & 19.4 & 17.0 & 0.30 & 0.80 & 0.40 & 2.35 & 0.06 \\
MB.C.30065 & 42.7 & 10.7 & 15.0 & 17.0 & 14.0 & 0.25 & 0.71 & 0.40 & 2.21 & 0.07 \\
MB.C.30064 & 42.4 & 13.4 & 15.4 & 17.0 & 14.5 & 0.32 & 0.87 & 0.40 & 2.31 & 0.06 \\
MB.C.30070 & 39.3 & 12.7 & 13.8 & 14.6 & 13.0 & 0.32 & 0.92 & 0.37 & 2.23 & 0.06 \\
\hline
\end{tabular}

\section{Stratigraphic range}

Upper part of the Hambast Formation; 0.75 to $0.40 \mathrm{~m}$ below the extinction horizon (Abichites stoyanowi Zone to lowest part of the Arasella minuta Zone).
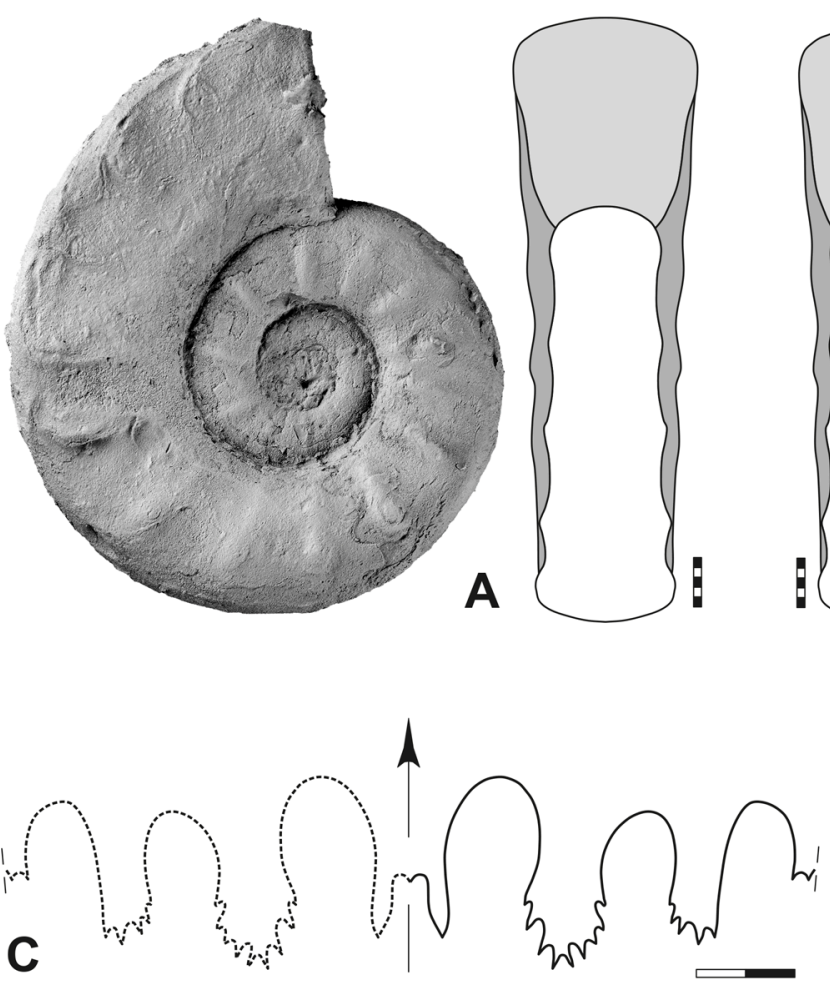
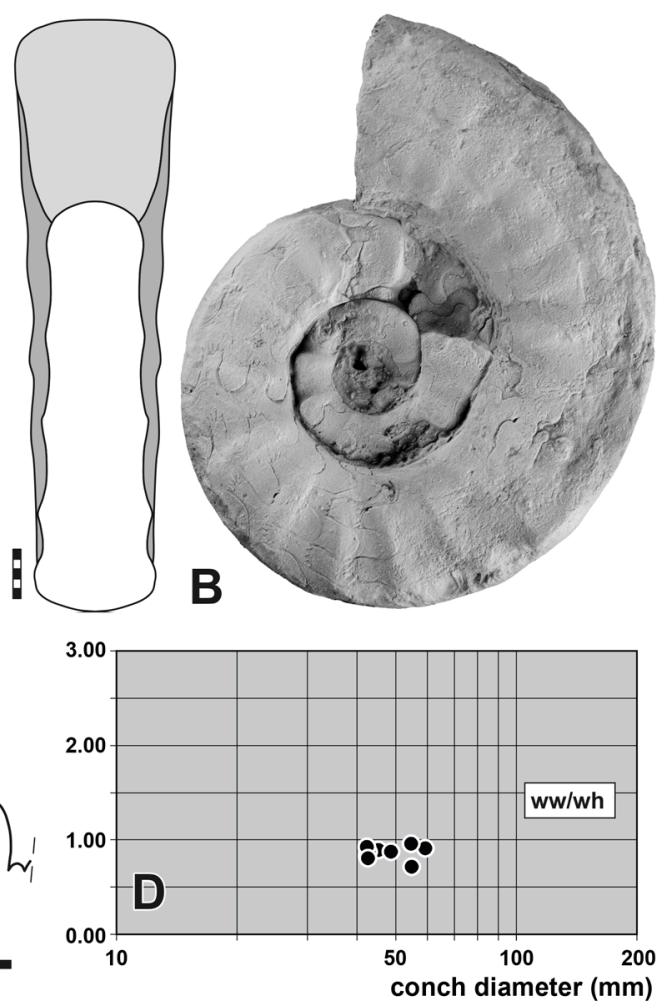

Fig. 58. Abichites ovalis Korn \& Hairapetian sp. nov. A. Lateral and dorsal view, holotype MB.C.30059, section B, float. B. Lateral and dorsal view, paratype MB.C.30071, section G, -0.40 m. C. Suture line, holotype MB.C.30059, at $14.2 \mathrm{~mm}$ wh. D. Whorl profile proportions. Abbreviation: see Material and methods. Scale bar units $=1 \mathrm{~mm}$. 
Abichites stoyanowi (Kiparisova in Voinova et al., 1947)

Fig. 59; Table 33

Kashmirites? stoyanowi Kiparisova in Voinova et al., 1947: 149, pl. 35 fig. 1.

Xenodiscus radians - Stoyanow 1910: 86, pl. 9 fig. 5.

Xenodiscus sp. indet. Stoyanow 1910: 87, pl. 9 fig. 6.

Abichites stoyanowi - Shevyrev 1965: 179, pl. 24 figs 2-3; 1968: 94, pl. 3 fig. 5, pl. 4 fig. 2. - Korn in Ghaderi et al. 2014: text-fig. 7h. - Korn \& Ghaderi in Korn et al. 2016: 881, text-fig. 38.

\section{Diagnosis}

Species of Abichites with conch reaching $70 \mathrm{~mm}$ dm. Subadult stage with circular, weakly compressed whorl profile $(\mathrm{ww} / \mathrm{wh}=0.75-1.00)$ and rounded venter; $16-20$ moderately weak ribs per volution. Adult stage with quadrate and weakly compressed whorl profile (ww/wh $=0.90-1.00)$, flat venter and subangular to angular ventrolateral shoulder; altogether 12-14 sharp concavo-convex ribs per half volution on flanks. Prongs of external lobe simple or bifid; 6-11 notches of E, A and L lobes.

\section{Material examined}

IRAN • 1 specimen; Esfahan Province, Baghuk Mountain 1 section; Hambast Formation; MB.C.30073 • 2 specimens; Esfahan Province, Baghuk Mountain C section; Hambast Formation; MB.C.30074 to MB.C.30075 - 3 specimens; Esfahan Province, Baghuk Mountain E section; Hambast Formation; MB.C.30076 to MB.C.30078 - 1 specimen; Esfahan Province, Baghuk Mountain F section; Hambast Formation; MB.C.30079 - 2 specimens; Esfahan Province, Baghuk Mountain G section; Hambast Formation; MB.C.30080 to MB.C.30081 • 1 specimen; Esfahan Province, Baghuk Mountain H section; Hambast Formation; MB.C.30082.

\section{Description}

Specimen MB.C. 30078 has $62 \mathrm{~mm}$ conch diameter and is rather well-preserved with the last half volution belonging to the body chamber (Fig. 59A). This has a subtrapezoidal, weakly compressed whorl profile $(\mathrm{ww} / \mathrm{wh}=0.90)$ with a broadly rounded umbilical margin, weakly concave converging flanks, an angular ventrolateral shoulder and a weakly concave venter. Two stages of the ornament are visible; the subadult stage has coarse node-like ribs on the flank, which in the adult stage become increasingly weaker and more numerous ( 15 per half volution at the beginning of the body chamber).

The suture line of specimen MB.C.30078 has a large external lobe with weakly diverging flanks and unsubdivided lanceolate prongs. The inverted U-shaped ventrolateral saddle is dorsally inclined and is followed by the pouched adventive lobe that has a very oblique base subdivided into three very shallow blunt notches. In contrast, the three notches of the parallel-sided lateral lobe are pointed denticles (Fig. 59E).

The two smaller specimens MB.C.30074 (31 mm dm; Fig. 59D) and MB.C.30081 (34 mm dm; Fig. 59B) have similar conch shapes and proportions; they differ in the somewhat weaker sculpture.

\section{Remarks}

Abichites stoyanowi differs from A. abichi, which is another similar species with moderately coarse sculpture, in the much weaker ribs. Abichites subtrapezoidalis has a similar whorl profile, but only very weak riblets around the umbilicus on the adult body chamber.

\section{Stratigraphic range}

Upper part of the Hambast Formation; 0.80 to $0.05 \mathrm{~m}$ below the extinction horizon (Abichites stoyanowi Zone to lowest part of the Arasella minuta Zone). 
KORN D. et al., Ammonoids from Baghuk Mountain

Table 33. Conch dimensions (partly estimated) and ratios of selected specimens of Abichites stoyanowi (Kiparisova in Voinova et al., 1947) from Baghuk Mountain.

\begin{tabular}{ccccccccccc}
\hline Specimen & dm & ww & wh & uw & ah & ww/dm & ww/wh & uw/dm & WER & IZR \\
\hline MB.C.30078 & 41.1 & 11.8 & 14.6 & 17.8 & 13.4 & 0.29 & 0.81 & 0.43 & 2.20 & 0.08 \\
MB.C.30079 & 37.7 & 12.4 & 13.3 & 14.8 & 12.2 & 0.33 & 0.93 & 0.39 & 2.19 & 0.08 \\
MB.C.30081 & 33.8 & 9.7 & 13.1 & 13.6 & 11.2 & 0.29 & 0.74 & 0.40 & 2.24 & 0.15 \\
MB.C.30074 & 30.9 & 9.9 & 11.6 & 11.7 & 10.6 & 0.32 & 0.86 & 0.38 & 2.31 & 0.09 \\
MB.C.30077 & 46.3 & 13.1 & 15.8 & 18.9 & 15.0 & 0.28 & 0.83 & 0.41 & 2.19 & 0.05 \\
MB.C.30076 & 41.0 & 10.6 & 12.8 & 16.7 & 12.2 & 0.26 & 0.83 & 0.41 & 2.03 & 0.05 \\
\hline
\end{tabular}
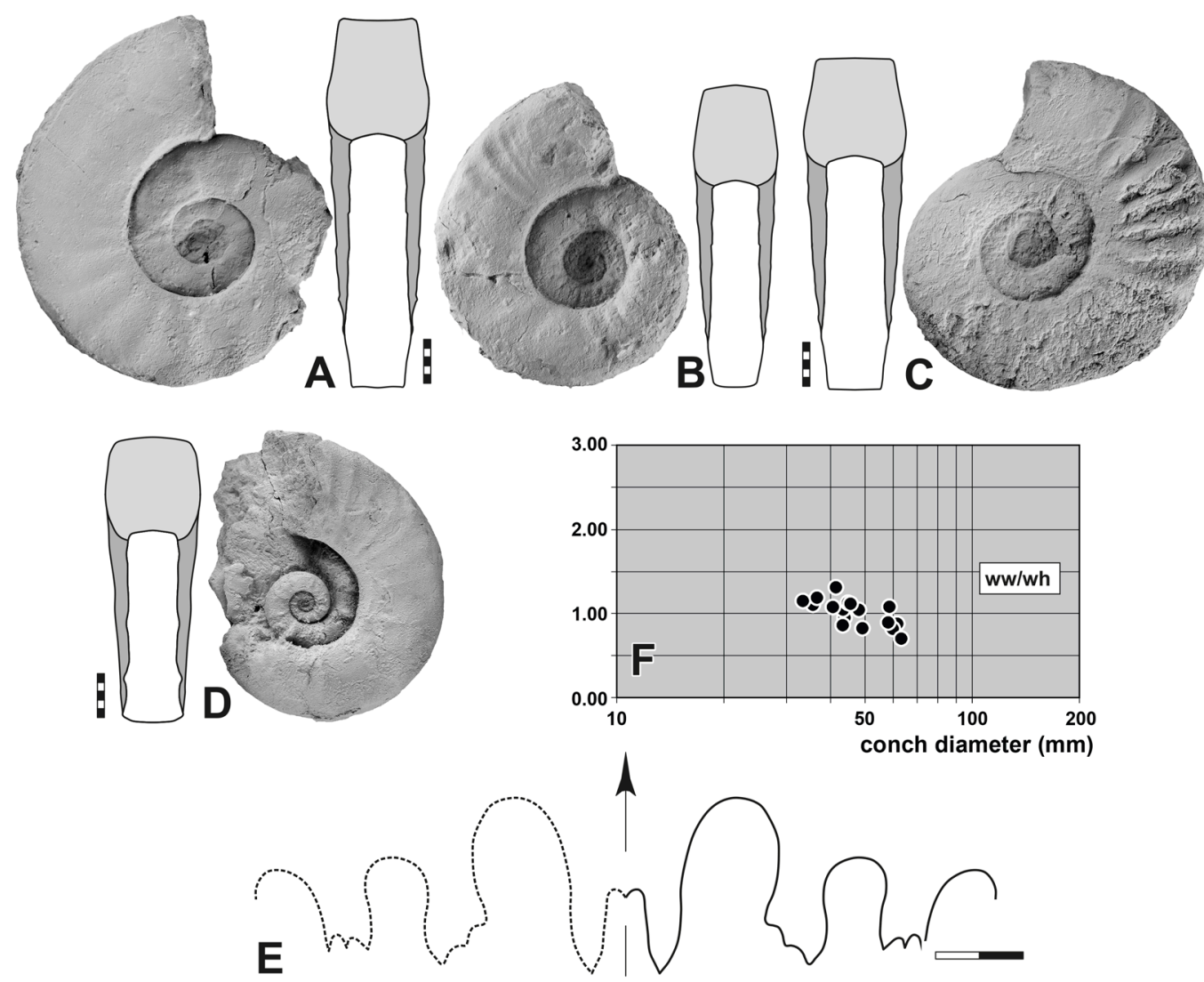

Fig. 59. Abichites stoyanowi (Kiparisova, 1947). A. Lateral and dorsal view, specimen MB.C.30078, section $\mathrm{G},-0.40 \mathrm{~m}$. B. Lateral and dorsal view, specimen MB.C.30081, section G, $-0.05 \mathrm{~m}$. C. Lateral and dorsal view, specimen MB.C.30079, section F, -0.75 m. D. Lateral and dorsal view, specimen MB.C.30074, section C, $-0.50 \mathrm{~m}$. E. Suture line, specimen MB.C.30078, at $7.2 \mathrm{~mm}$ ww, $7.4 \mathrm{~mm}$ wh. F. Whorl profile proportions. Abbreviations: see Material and methods. Scale bar units $=1 \mathrm{~mm}$. 
Abichites infirmis Korn \& Hairapetian sp. nov.

urn:Isid:zoobank.org:act:DF627B6D-3446-4B02-89B2-81ED420C876D

Fig. 60; Table 34

\section{Diagnosis}

Species of Abichites with conch reaching $50 \mathrm{~mm}$ dm. Subadult stage with oval, weakly compressed whorl profile $(\mathrm{ww} / \mathrm{wh}=0.60-0.80)$ and rounded venter; very weak, rounded nodes. Adult stage with weakly subtrapezoidal, weakly compressed whorl profile $(\mathrm{ww} / \mathrm{wh}=0.60-0.80)$ with weakly converging flat flanks, weakly flattened venter and narrowly subangular ventrolateral shoulder. Sculpture with faint plications. Prongs of external lobe simple; altogether 5-6 notches of E, A and L lobes.

\section{Etymology}

From the Latin 'infirmis', meaning 'barely visible', because of the weak sculpture.

\section{Material examined}

\section{Holotype}

IRAN • Esfahan Province, Baghuk Mountain G section; Hambast Formation, $0.40 \mathrm{~m}$ below the top; illustrated in Fig. 60A; MB.C.30086.

\section{Paratypes}

IRAN • 1 specimen; Esfahan Province, Baghuk Mountain 1 section; Hambast Formation; MB.C.30083 • 1 specimen; Esfahan Province, Baghuk Mountain C section; Hambast Formation; MB.C.30084 • 1 specimen; Esfahan Province, Baghuk Mountain E section; Hambast Formation; MB.C.30085 • 2 specimens; Esfahan Province, Baghuk Mountain G section; Hambast Formation; MB.C.30087 to MB.C.30088.

\section{Description}

Holotype MB.C.30086 is a rather well-preserved specimen with $42 \mathrm{~mm}$ conch diameter (Fig. 60A). The whorl profile of the body chamber is subtrapezoidal with a narrowly rounded umbilical margin, flat and weakly converging flanks, a subangular ventrolateral shoulder and a flattened but still broadly rounded venter. Its ww/wh ratio is 0.70 and the whorl embraces the preceding one only weakly. The shell appears to be smooth except for very faint plications.

The suture line of the holotype has a parallel-sided external lobe that has a width/depth ratio of $\sim 0.75$. It is deeper than the adventive lobe and possesses unsubdivided lanceolate prongs. The ventrolateral

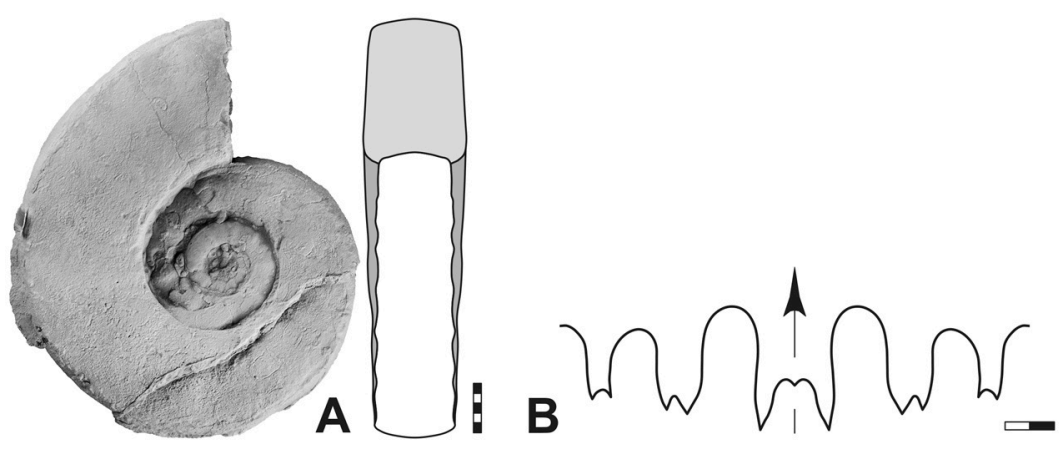

Fig. 60. Abichites infirmis Korn \& Hairapetian sp. nov. A. Lateral and dorsal view, holotype MB.C.30086, section G, $-0.40 \mathrm{~m}$. B. Suture line, holotype MB.C.30086, at $21.5 \mathrm{~mm} \mathrm{dm}, 9.1 \mathrm{~mm}$ wh. Abbreviations: see Material and methods. Scale bar units $=1 \mathrm{~mm}$. 
Table 34. Conch dimensions (partly estimated) and ratios of selected specimens of Abichites infirmis Korn \& Hairapetian sp. nov. from Baghuk Mountain.

\begin{tabular}{ccccccccccc}
\hline Specimen & dm & ww & wh & uw & ah & ww/dm & ww/wh & uw/dm & WER & IZR \\
\hline MB.C.30086 & 41.6 & 10.4 & 14.7 & 15.5 & 13.6 & 0.25 & 0.71 & 0.37 & 2.21 & 0.07 \\
MB.C.30088 & 36.9 & 8.8 & 13.2 & 13.6 & 12.3 & 0.24 & 0.67 & 0.37 & 2.25 & 0.07 \\
MB.C.30087 & 33.6 & 7.7 & 12.4 & 12.6 & 11.4 & 0.23 & 0.62 & 0.38 & 2.29 & 0.08 \\
MB.C.30083 & 33.1 & 9.4 & 12.4 & 13.3 & 11.3 & 0.28 & 0.76 & 0.40 & 2.31 & 0.09 \\
\hline
\end{tabular}

saddle is inverted U-shaped and symmetric and the weakly asymmetric, parallel-sided adventive lobe is subdivided into two secondary notches. The narrow lateral saddle is also inverted U-shaped and followed by a parallel-sided lateral lobe with two notches (Fig. 60B).

\section{Remarks}

Abichites infirmis differs from most of the species of the genus in the lack of coarse ribs or nodes. Similar species are A. paucinodus (which possesses few coarse nodes on the flanks) and A. terminalis (with an oval whorl profile).

\section{Stratigraphic range}

Upper part of the Hambast Formation; 0.40 to $0.05 \mathrm{~m}$ below the extinction horizon (Arasella minuta Zone).

Genus Stoyanowites Korn in Ghaderi et al., 2014

\section{Type species}

Paratirolites dieneri Stoyanow, 1910, by original designation

\section{Included species}

Stoyanowites aspinosus Korn \& Ghaderi in Korn et al., 2016; Paratirolites dieneri Stoyanow, 1910; Stoyanowites parallelus Korn \& Hairapetian sp. nov.

\section{Diagnosis}

Genus of the family Dzhulfitidae with moderately large conch; maximum adult diameters are between 80 and $95 \mathrm{~mm}$. Subadult and adult stages with rectangular and compressed whorl profile. Subadult stage with weak to moderately strong lateral ribs; adult stage with weak ornament. Suture line with an external lobe that is much shorter than the adventive lobe.

\section{Remarks}

Stoyanowites is separated from most of the other genera of the family Dzhulfitidae by the short external lobe, which does not reach the depth of the adventive and lateral lobes. Only Dzhulfites is similar in this respect, but this genus is characterised by coarse ventrolateral nodes absent in Stoyanowites.

Stoyanowites dieneri (Stoyanow, 1910)

Fig. 61, Table 35

Paratirolites Dieneri Stoyanow, 1910: 83, pl. 8 fig. 2. 
Paratirolites dieneri - Spath 1934: 366, text-fig. 125e. - Shevyrev 1965: 178, pl. 23 figs 2-3; 1968: 93 , pl. 3 figs $2-3$.

Stoyanowites dieneri - Korn in Ghaderi et al. 2014: text-fig. 7F. — Korn \& Ghaderi in Korn et al. 2016: 884, text-fig. 42.

Paratirolites mojsisovicsi - Teichert \& Kummel in Teichert et al. 1973: pl. 7 fig. 1.

\section{Diagnosis}

Species of Stoyanowites with conch reaching $120 \mathrm{~mm} \mathrm{dm}$. Subadult stage with oval, weakly compressed whorl profile $(\mathrm{ww} / \mathrm{wh}=0.70-0.80)$ and rounded venter; 16 fine ribs forming weak and rounded dorsolateral and ventrolateral nodes. Adult stage with parallel flanks and weakly compressed whorl profile $(\mathrm{ww} / \mathrm{wh}=0.60-0.70)$, rounded venter and subangular ventrolateral shoulder; weak dorsolateral nodes. Prongs of external lobe bifid; altogether 10-16 notches of E, A and L lobes; external lobe shorter than adventive lobe.

\section{Material examined}

IRAN • 3 specimens; Esfahan Province, Baghuk Mountain E section; Hambast Formation; MB.C.30089 to MB.C.30091 - 1 specimen; Esfahan Province, Baghuk Mountain H section; Hambast Formation; MB.C.30092 - 4 specimens; Esfahan Province, Baghuk Mountain section; Hambast Formation; MB.C.30093 to MB.C.30096.

\section{Description}

Specimen MB.C.30090 has $74 \mathrm{~mm}$ conch diameter and is fairly well preserved if partly crushed and weathered (Fig. 61A). Nearly half of the last volution belongs to the body chamber. At the end of the preserved part of the body chamber, the whorl profile is compressed (ww/wh $=0.70)$ and has nearly parallel, only weakly converging flanks, a subangular ventrolateral shoulder and a flat venter. One volution earlier, the whorl profile is oval with rounded venter. The sculpture on the body chamber consists of faint radial riblets and pronounced isolated ventrolateral spines, ten per half volution. The penultimate volution is corroded, but it appears that the sculpture is weaker than on the terminal body chamber.

The suture line of specimen MB.C.30090 has the characteristic short external lobe with bifid, nearly parallel-sided prongs (Fig. 61C). Both the adventive lobe and the lateral lobe are also nearly parallelsided, they show four small notches.

The smaller specimen MB.C.30089 has a weaker sculpture than the preceding specimen (Fig. 61B). It shows weak ventrolateral spines and weak radial plications on the flank. Its suture line has a weakly pouched, short external lobe with bifid prongs; the pouched adventive lobe and the parallel-sided lateral lobes are trifid (Fig. 61D).

\section{Remarks}

Stoyanowites dieneri differs from S. aspinosus, which is clearly separated from $S$. dieneri because of its wider umbilicus and the lack of spines. Stoyanowites parallelus sp. nov. differs in the flat venter and the more numerous ribs and ventrolateral spines.

\section{Stratigraphic range}

Upper part of the Hambast Formation; the only one in situ collected specimen comes from $1.80 \mathrm{~m}$ below the extinction horizon (Alibashites ferdowsii Zone). 
KORN D. et al., Ammonoids from Baghuk Mountain

Table 35. Conch dimensions (partly estimated) and ratios of selected specimens of Stoyanowites dieneri (Stoyanow, 1910) from Baghuk Mountain.

\begin{tabular}{ccccccccccc}
\hline Specimen & dm & ww & wh & uw & ah & ww/dm & ww/wh & uw/dm & WER & IZR \\
\hline MB.C.30090 & 74.0 & 14.8 & 23.3 & 32.4 & 22.6 & 0.20 & 0.64 & 0.44 & 2.07 & 0.03 \\
MB.C.30090 & 58.8 & 13.3 & 19.1 & 28.2 & - & 0.23 & 0.70 & 0.48 & - & - \\
MB.C.30089 & 49.8 & 13.0 & 17.5 & 21.5 & 15.8 & 0.26 & 0.74 & 0.43 & 2.15 & 0.10 \\
MB.C.30093 & 79.4 & - & 25.0 & 34.8 & 24.0 & - & - & 0.44 & 2.05 & 0.04 \\
MB.C.30091 & 60.6 & - & 18.8 & 27.6 & 18.0 & - & - & 0.46 & 2.02 & 0.04 \\
MB.C.30096 & 47.5 & - & 15.7 & 20.7 & 15.0 & - & - & 0.44 & 2.14 & 0.04 \\
\hline
\end{tabular}
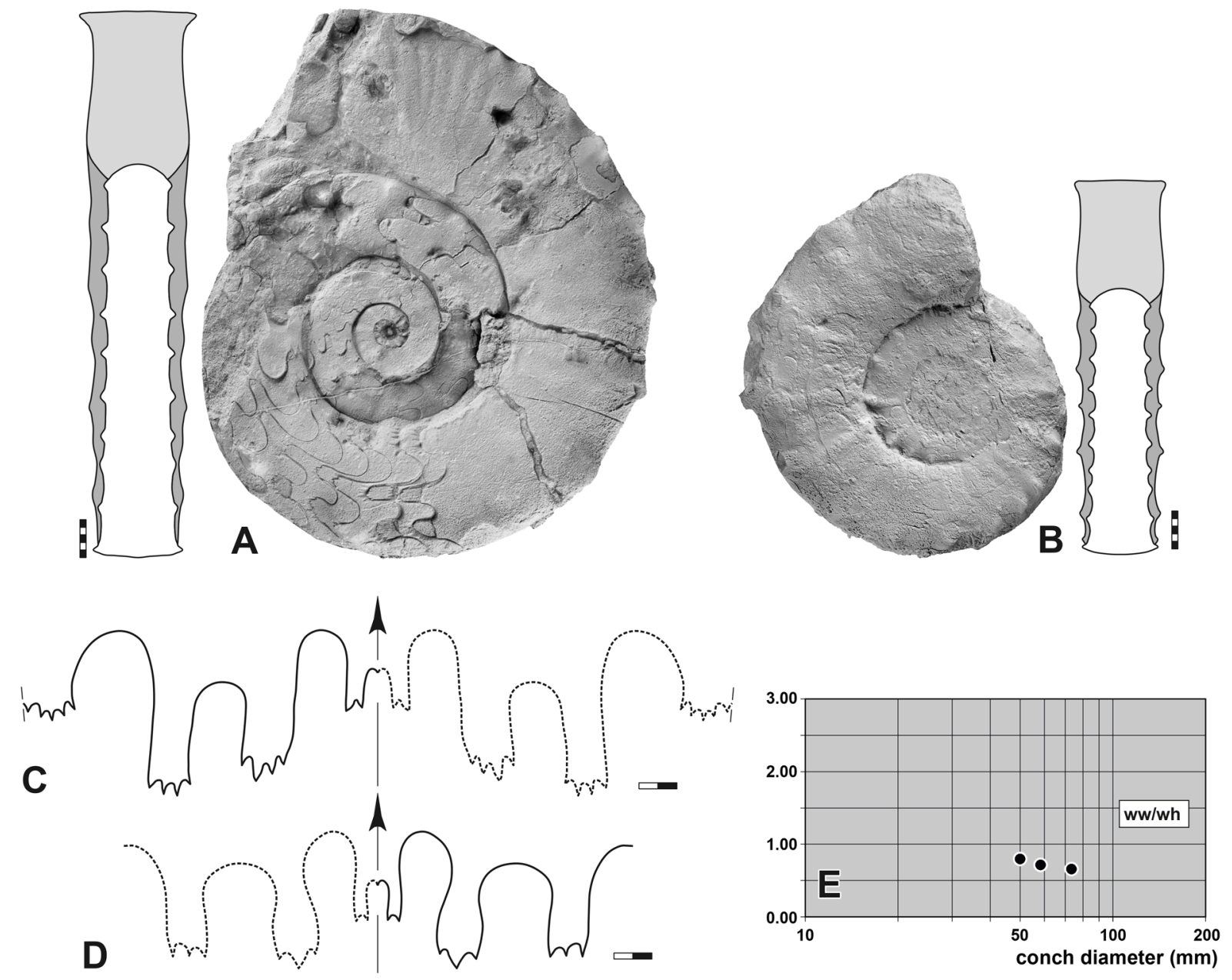

Fig. 61. Stoyanowites dieneri (Stoyanow, 1910). A. Lateral and dorsal view, specimen MB.C.30090, section E, float. B. Lateral and dorsal view, specimen MB.C.30089, section E, float. C. Suture line, specimen MB.C.30090, at $12.4 \mathrm{~mm}$ ww, $17.4 \mathrm{~mm}$ wh. D. Suture line, specimen MB.C.30089, at $14.4 \mathrm{~mm}$ wh. E. Whorl profile proportions. Abbreviations: see Material and methods. Scale bar units $=1 \mathrm{~mm}$. 
Stoyanowites aspinosus Korn \& Ghaderi in Korn et al., 2016

Fig. 62; Table 36

Stoyanowites aspinosus Korn \& Ghaderi in Korn et al., 2016: 885, text-fig. 43.

\section{Diagnosis}

Species of Stoyanowites with conch reaching $100 \mathrm{~mm} \mathrm{dm}$. Subadult stage with oval, weakly compressed whorl profile $(\mathrm{ww} / \mathrm{wh}=0.70)$ and rounded venter; 15 narrow and rounded ribs on the flanks. Adult stage with oval and weakly compressed whorl profile $(\mathrm{ww} / \mathrm{wh}=0.60-0.70)$ and moderately wide to wide umbilicus $(\mathrm{uw} / \mathrm{dm}=0.40-0.50)$, rounded venter and rounded ventrolateral shoulder; very weak ribs on the flanks, coarsest in ventrolateral area. Prongs of external lobe bifid; 8-9 notches of E, A and L lobes.

\section{Material examined}

Holotype

IRAN - West Azerbaijan, Aras Valley section; Paratirolites Limestone, $0.95 \mathrm{~m}$ below the top; illustrated by Korn \& Ghaderi in Korn et al. (2016: text-fig. 43a); MB.C.25458.

\section{Additional material}

IRAN • 1 specimen; Esfahan Province, Baghuk Mountain 1 section; Hambast Formation; MB.C.300978 • 2 specimens; Esfahan Province, Baghuk Mountain A section; Hambast Formation; MB.C.30098 to MB.C.30099 - 1 specimen; Esfahan Province, Baghuk Mountain C section; Hambast Formation; MB.C.30100 - 1 specimen; Esfahan Province, Baghuk Mountain E section; Hambast Formation; MB.C.30101.

\section{Description}

Specimen MB.C. 30100 is a fragmentary specimen with $72 \mathrm{~mm}$ diameter and shows the wide umbilicus (uw/dm $=0.50$ ), the nearly parallel-sided whorl profile and the rounded venter. The ornament of the last half volution consists of numerous (about 25) rather sharp ribles, which extend with a shallow sinus across the flanks and turn forward in the ventrolateral area, where they become coarser and for a hooklike rib (Fig. 62A). The venter is smooth.
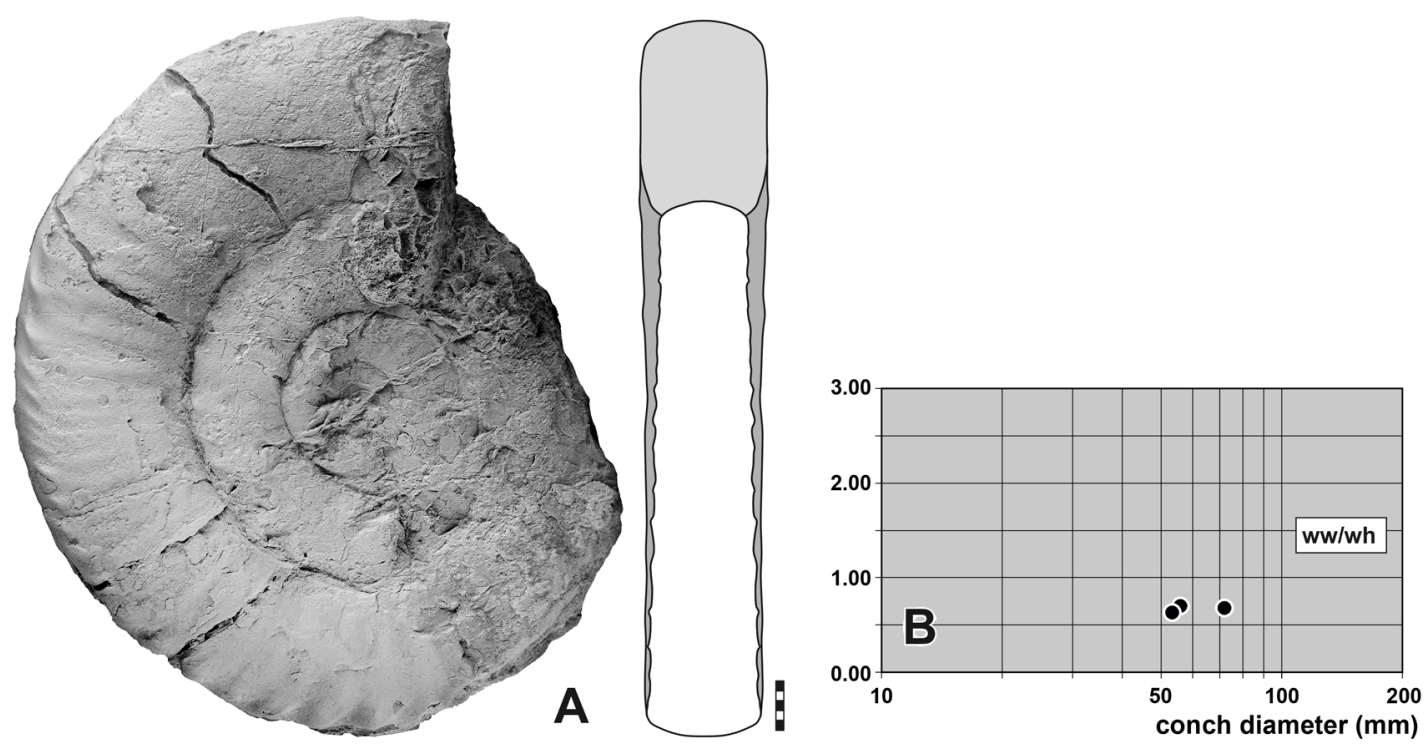

Fig. 62. Stoyanowites aspinosus Korn \& Ghaderi, 2016. A. Lateral and dorsal view, specimen MB.C. 30100 , section C, $-1.60 \mathrm{~m}$. B. Whorl profile proportions. Scale bar units $=1 \mathrm{~mm}$. 
Table 36. Conch dimensions (partly estimated) and ratios of selected specimens of Stoyanowites aspinosus Korn \& Ghaderi in Korn et al., 2016 from Baghuk Mountain.

\begin{tabular}{ccccccccccc}
\hline Specimen & $\mathbf{d m}$ & $\mathbf{w w}$ & $\mathbf{w h}$ & $\mathbf{u w}$ & $\mathbf{a h}$ & $\mathbf{w w} / \mathbf{d m}$ & $\mathbf{w w} / \mathbf{w h}$ & $\mathbf{u w} / \mathbf{d m}$ & WER & IZR \\
\hline MB.C.30100 & 71.7 & 13.8 & 20.4 & 37.3 & 19.8 & 0.19 & 0.68 & 0.52 & 1.91 & 0.03 \\
MB.C.30100 & 56.1 & 10.8 & 15.5 & 27.1 & - & 0.19 & 0.70 & 0.48 & - & - \\
MB.C.30097 & 56.0 & - & 16.2 & 26.7 & 15.7 & - & - & 0.48 & 1.93 & 0.03 \\
MB.C.30099 & 53.5 & 11.6 & 18.4 & 24.0 & 16.7 & 0.22 & 0.63 & 0.45 & 2.11 & 0.09 \\
MB.C.30098 & 58.2 & 12.7 & 19.1 & 25.3 & 18.1 & 0.22 & 0.66 & 0.43 & 2.11 & 0.05 \\
\hline
\end{tabular}

\section{Remarks}

Stoyanowites aspinosus differs from $S$. dieneri in the absence of dorsolateral nodes and the presence of densely spaced curved riblets on the body chamber. Stoyanowites parallelus sp. nov. differs in the flat venter.

\section{Stratigraphic range}

Upper part of the Hambast Formation; 1.80 to $1.60 \mathrm{~m}$ below the extinction horizon (Alibashites ferdowsii Zone).

Stoyanowites parallelus Korn \& Hairapetian sp. nov. urn:1sid:zoobank.org:act:E6C0C2D8-02EF-4E72-9E1E-78816A50573E

Fig. 63; Table 37

\section{Diagnosis}

Species of Stoyanowites with conch reaching $100 \mathrm{~mm} \mathrm{dm}$. Subadult stage with rectangular, compressed whorl profile $(\mathrm{ww} / \mathrm{wh}=0.70)$, subangular ventrolateral shoulder and flattened venter; 10 rather coarse ventrolateral spines per half volution. Adult stage with parallel-sided, compressed whorl profile (ww/ $w h=0.60$ ), flat venter and angular ventrolateral shoulder; 15 ventrolateral spines per half volution. Prongs of external lobe simple; altogether 13 notches of $\mathrm{E}, \mathrm{A}$ and $\mathrm{L}$ lobes.

\section{Etymology}

Named after the parallel flanks of the whorl profile.

\section{Material examined}

\section{Holotype}

IRAN - Esfahan Province, Baghuk Mountain C section; Hambast Formation, $1.70 \mathrm{~m}$ below the top; illustrated in Fig. 63A; MB.C.30102.

\section{Paratypes}

IRAN • 2 specimens; Esfahan Province, Baghuk Mountain E section; Hambast Formation; MB.C.30103 to MB.C.30104 - 1 specimen; Esfahan Province, Baghuk Mountain G section; Hambast Formation; MB.C.30105.

\section{Description}

Holotype MB.C.30102 is an incomplete specimen of $72 \mathrm{~mm}$ diameter; it allows the study of conch shape, ornament and suture line. The conch is extremely discoidal ( $\mathrm{ww} / \mathrm{dm}=0.19)$ with a wide umbilicus (uw/ 
Table 37. Conch dimensions (partly estimated) and ratios of the holotype of Stoyanowites parallelus Korn \& Hairapetian sp. nov. from Baghuk Mountain.

\begin{tabular}{ccccccccccc}
\hline Specimen & dm & ww & wh & uw & ah & ww/dm & ww/wh & uw/dm & WER & IZR \\
\hline MB.C.30102 & 72.2 & 13.7 & 22.5 & 33.7 & 21.8 & 0.19 & 0.61 & 0.47 & 2.05 & 0.03 \\
\hline
\end{tabular}

$\mathrm{dm}=0.47)$ and a compressed whorl profile (ww/wh $=0.61)$. It has nearly parallel, slightly concave flanks, a prominent subangular ventrolateral shoulder and a weakly concave venter at the largest diameter (Fig. 63A). The sculpture is dominated by coarse ventrolateral spines, which become weaker towards the end of growth, but of which are still 15 are present on half a volution of the body chamber. They are not always connected with short ribs on the inner flank.

The suture line of holotype MB.C.30102 shows the short external lobe, which has simple, weakly pouched prongs. The ventrolateral saddle is rather narrow; the adventive and lateral lobes possess six notches (Fig. 63B).

\section{Remarks}

Stoyanowites parallelus sp. nov. differs from $S$. dieneri and $S$. aspinosus in the flat venter and the numerous sharp ventrolateral nodes in the adult stage.

\section{Stratigraphic range}

Upper part of the Hambast Formation; $1.70 \mathrm{~m}$ below the extinction horizon (Alibashites ferdowsii Zone).
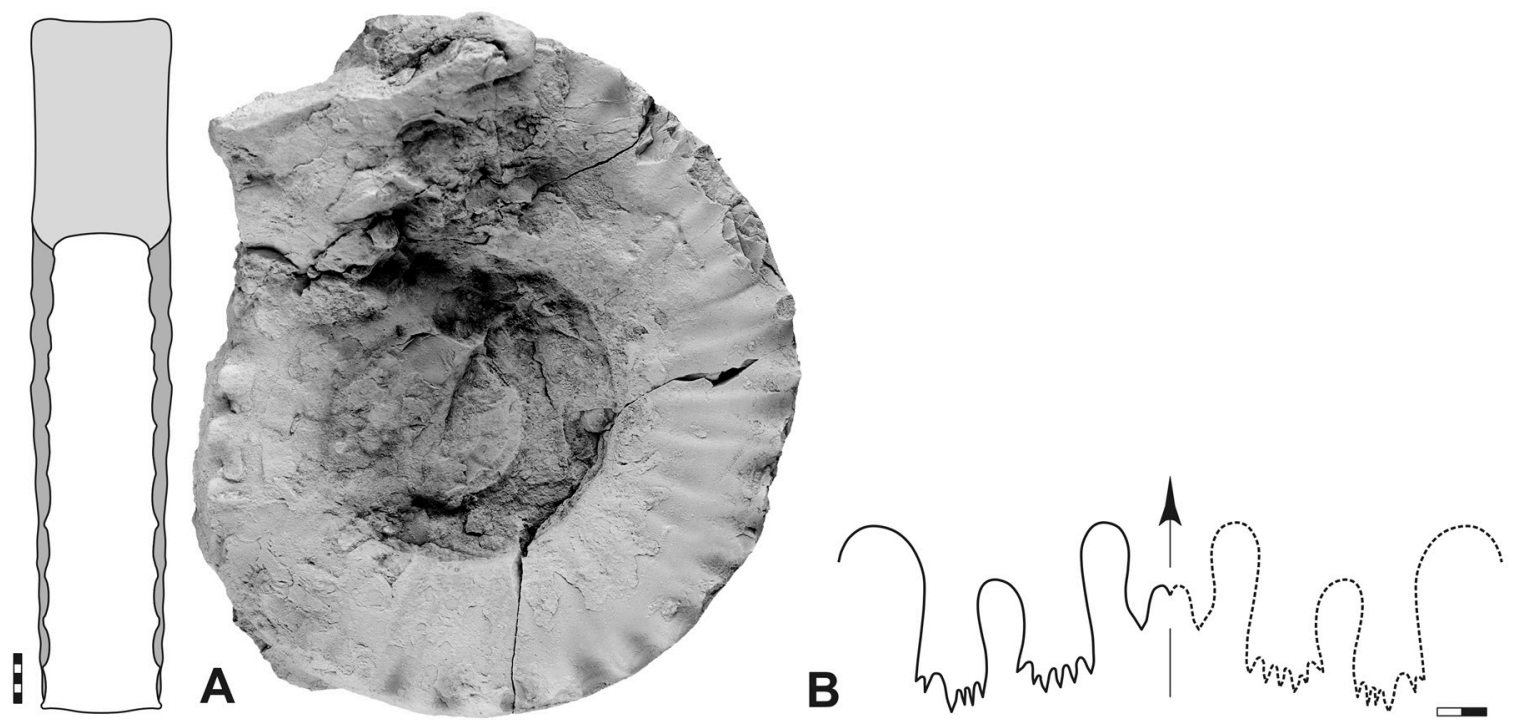

Fig. 63. Stoyanowites parallelus Korn \& Hairapetian sp. nov. A. Lateral and dorsal view, holotype MB.C.30102, section C, $-1.70 \mathrm{~m}$. B. Suture line, holotype MB.C.30102, at $17.5 \mathrm{~mm}$ wh. Abbreviation: see Material and methods. Scale bar units $=1 \mathrm{~mm}$. 


\section{Discussion}

Baghuk Mountain (Central Iran) is the world's most diverse locality for Late Permian ammonoids. The sections have so far yielded eleven genera (Pseudogastrioceras, Shevyrevites, Arasella, Dzhulfites, Paratirolites, Clivotirolites gen. nov., Esfahanites gen. nov., Alibashites, Lutites gen. nov., Abichites and Stoyanowites) and 37 species of ammonoids from the Changhsingian. The succession of ammonoid species allows for a subdivision of the rock unit into biozones, which largely correspond with the occurrences in north-western Iran.

Three new genera, Clivotirolites, Esfahanites and Lutites, as well as 19 new species are described: Shevyrevites corrugatus Korn \& Hairapetian sp. nov., Arasella falcata Korn \& Hairapetian sp. nov., Dzhulfites brevisellatus Korn \& Hairapetian sp. nov., Paratirolites rubens Korn \& Hairapetian sp. nov., Paratirolites lanceolobatus Korn \& Hairapetian sp. nov., Paratirolites robustus Korn \& Hairapetian sp. nov., Paratirolites baghukensis Korn \& Hairapetian sp. nov., Paratirolites aduncus Korn \& Hairapetian sp. nov., Clivotirolites decoratus Korn \& Hairapetian gen. et sp. nov., Clivotirolites petilus Korn \& Hairapetian gen. et sp. nov., Esfahanites armatus Korn \& Hairapetian gen. et sp. nov., Lutites paucis Korn \& Hairapetian gen. et sp. nov., Lutites lyriformis Korn \& Hairapetian gen. et sp. nov., Lutites profundus Korn \& Hairapetian gen. et sp. nov., Lutites alius Korn \& Hairapetian gen. et sp. nov., Lutites plicatus Korn \& Hairapetian gen. et sp. nov., Abichites ovalis Korn \& Hairapetian sp. nov., Abichites infirmus Korn \& Hairapetian sp. nov. and Stoyanowites parallelus Korn \& Hairapetian sp. nov. The other 18 species are already known from localities in the Transcaucasus (Armenia, Azerbaijan) and north-western Iran.

\section{Acknowledgements}

We are indebted to the Islamic Azad University for the support of the field sessions at Baghuk Mountain. We greatly acknowledge Evelin Stenzel and Markus Brinkmann (Berlin) for the preparation as well as Jonas Jahn, Sebastian Sladeczek and Jenny Huang (Berlin) for the photography of the specimens. The Deutsche Forschungsgemeinschaft (DFG) provided financial support for the project (projects Ko1829/12-1, Ko1829/15-1, Ko1829/18-1 and FOR2332). We greatly acknowledge the reviews by Arnaud Brayard (Dijon) and an anonymous reviewer.

\section{References}

Bando Y. 1979. Upper Permian and Lower Triassic ammonoids from Abadeh, Central Iran. Memoirs of the Faculty of Education, Kagawa University 29: 103-182.

Bando Y. 1981. Discovery of Lower Triassic ammonites in the Abadeh region of Central Iran. Geolological Survey of Iran, Report 49: 73-103.

Baud A., Richoz S., Brandner R., Krystyn L., Heindel K., Mohtat T. \& Mohtat-Aghai P. 2021. Sponge takeover from End-Permian mass extinction to early Induan time: records in Central Iran microbial buildups. Frontiers in Earth Science 8: 586210. https://doi.org/10.3389/feart.2021.586210

Farshid E., Hamdi B., Hairapetian V. \& Aghanabati S.A. 2016. Conodont biostratigraphy of the PermianTriassic boundary in the Baghuk mountain section Northwest of Abadeh. Scientific Quarterly Journal, Geosciences 25: 285-294. https://doi.org/10.22071/GSJ.2016.40939

Ghaderi A., Leda L., Schobben M., Korn D. \& Ashouri A.R. 2014. High-resolution stratigraphy of the Changhsingian (Late Permian) successions of NW Iran and the Transcaucasus based on lithological features, conodonts, and ammonoids. Fossil Record 15: 41-57. https://doi.org/10.5194/fr-17-41-2014

Ghaedi M., Mousavi N. \& Yazdi M. 2009. Scrutiny and biozonation of Permian - Triassic boundary in Benarizeh area, north of Abadeh. Second Conference of the Iranian Paleontological Association: 1-4. 
Heuer F., Leda L., Moradi Salimi H., Gliwa J., Hairapetian V. \& Korn D. in press. The PermianTriassic boundary section at Baghuk Mountain, Central Iran: carbonate microfacies and depositional environment. Palaeobiodiversity and Palaeoenvironments.

Kiessling W., Schobben M., Ghaderi A., Hairapetian V., Leda L. \& Korn D. 2018. Pre-mass extinction decline of latest Permian ammonoids. Geology 46: 283-286. https://doi.org/10.1130/G39866.1

Klug C., Korn D., Landman N.H., Tanabe K., De Baets K. \& Naglik C. 2015. Describing ammonoid conchs. In: Klug C., Korn D., De Baets K., Kruta I. \& Mapes R.H. (eds) Ammonoid Paleobiology: From Macroevolution to Paleogeography, Topics in Geobiology 44: 3-24. Springer, Dordrecht. https://doi.org/10.1007/978-94-017-9630-9_1

Korn D. 2010. A key for the description of Palaeozoic ammonoids. Fossil Record 13: 5-12. https://doi.org/10.1002/mmng.200900008

Korn D. \& Ghaderi A. 2019. The Late Permian araxoceratid ammonoids: a case of repetitive temporal and spatial unfolding of homoplastic conch characters. Neues Jahrbuch für Geologie und Paläontologie, Abhandlungen 292: 339-350. https://doi.org/10.1127/njgpa/2019/0826

Korn D., Ebbighausen V., Bockwinkel J. \& Klug C. 2003. The A-mode sutural ontogeny in prolecanitid ammonoids. Palaeontology 46: 1123-1132. https://doi.org/10.1046/j.0031-0239.2003.00336.x

Korn D., Ghaderi A., Leda L., Schobben M. \& Ashouri A.R. 2016. The ammonoids from the Late Permian Paratirolites Limestone of Julfa (East Azerbaijan, Iran). Journal of Systematic Palaeontology 14: 841-890. https://doi.org/10.1080/14772019.2015.1119211

Korn D., Ghaderi A. \& Ghanizadeh Tabrizi N. 2019. Early Changhsingian (Late Permian) ammonoids from NW Iran. Neues Jahrbuch für Geologie und Paläontologie, Abhandlungen 293: 37-56. https://doi.org/10.1127/njgpa/2019/0829

Korn D., Leda L., Heuer F., Moradi Salimi H., Farshid E., Akbari A., Schobben M., Ghaderi A., Struck U., Gliwa J., Ware D. \& Hairapetian V. 2021. Baghuk Mountain (Central Iran): high-resolution stratigraphy of a continuous Central Tethyan Permian-Triassic boundary section. Fossil Record 24: 171-192. https://doi.org/10.5194/fr-24-171-2021

Kotlyar G.V., Zakharov Y.D., Koczyrkevicz B.V., Kropatcheva G.S., Rostovcev L.O., Chedija I.O., Vuks G.P. \& Guseva E.A. 1983. Posdnepermskiy etap evolyutsii organicheskogo mirA. Dzhulficheskiy i dorashamskiy yarusy SSSR. NAUKA, Leningrad.

Kozur H.W. 2005. Pelagic uppermost Permian and the Permian-Triassic boundary conodonts of Iran. Part II: Investigated sections and evaluation of the conodont faunas. Hallesches Jahrbuch für Geowissenschaften, Reihe B, Beiheft 19: 49-86.

Kummel B. 1957. Suborder Ceratitina Hyatt, 1884. In: Moore R.C. (ed.) Treatise on Invertebrate Paleontology. Part L, Mollusca, Ammonoidea 4: L130-L185.

Leda L., Korn D., Ghaderi A., Hairapetian V., Struck U. \& Reimold W.U. 2014. Lithostratigraphy and carbonate microfacies across the Permian-Triassic boundary near Julfa (NW Iran) and in the Baghuk Mountains (Central Iran). Facies 60: 295-325. https://doi.org/10.1007/s10347-013-0366-0

Liang X. 1983. New material of Permian ammonoids with discussion on the origin, migration of Araxoceratidae and the horizon of the Paratirolites. Acta Palaeontologica Sinica 22 (6): 606-615.

Schindewolf O.H. 1929. Vergleichende Studien zur Phylogenie, Morphologie und Terminologie der Ammoneen-Lobenlinie. Abhandlungen der Preußischen Geologischen Landesanstalt, Neue Folge 115: $1-102$. 
KORN D. et al., Ammonoids from Baghuk Mountain

Shevyrev A.A. 1965. Nadortyad Ammonoidea. In: Ruzhencev V.E. \& Sarytcheva T.G. (eds) Rasvitie i smena morskikh organizmov na rubezhe Paleozoya i Mezozoya. Trudy Paleontologicheskogo Instituta Akademiya Nauk SSSR 108: 166-182.

Shevyrev A.A. 1968. Triasovye ammonoidei Yuga SSSR. Trudy Paleontologicheskogo Instituta Akademiya Nauk SSSR 119: 1-272.

Spath L.F. 1934. Catalogue of the Fossil Cephalopoda in the British Museum (Natural History). Part IV. The Ammonoidea of the Trias. British Museum (Natural History), Department of Geology, London. https://doi.org/10.5962/bhl.title.112429

Stampfli G.M. \& Borel G.D. 2002. A plate tectonic model for the Paleozoic and Mesozoic constrained by dynamic plate boundaries and restored synthetic oceanic isochrons. Earth and Planetary Science Letters 196: 17-33. https://doi.org/10.1016/S0012-821X(01)00588-X

Stepanov D.L., Golshani F. \& Stöcklin J. 1969. Upper Permian and Permian-Triassic Boundary in North Iran. Geolological Survey of Iran, Report 12: 1-72.

Stoyanow A.A. 1910. On the character of the boundary of Palaeozoic and Mesozoic near Djulfa. Zapiski Imperatorskago St.-Peterburgskago Mineralogiceskago Obscestva [=Verhandlungen der RussischKaiserlichen Mineralogischen Gesellschaft zu St. Petersburg], ${ }^{\text {nd }}$ Series 47: 61-135.

Taraz H. 1969. Permo-Triassic Section in Central Iran. Bulletin of the American Association of Petroleum Geologists 53 (3): 688-693. https://doi.org/10.1306/5D25C6AB-16C1-11D7-8645000102C1865D

Taraz H. 1971. Uppermost Permian and Permian-Triassic Transition beds in Central Iran. Bulletin of the American Association of Petroleum Geologists 55: 1280-1294.

https://doi.org/10.1306/819A3CDC-16C5-11D7-8645000102C1865D

Taraz H. 1973. Correlation of Uppermost Permian in Iran, Central Asia, and South China. Bulletin of the American Association of Petroleum Geologists 57: 1117-1133.

https://doi.org/10.1306/83D90E67-16C7-11D7-8645000102C1865D

Taraz H., Golshani F., Nakazawa K., Sgimuzu D., Bando Y., Ishi K.-i., Murata M., Okimura Y., Sakagami S., Nakamura K. \& Tokuoka T. 1981. The Permian and the Lower Triassic Systems in Abadeh Region, Central Iran. Memoirs of the Faculty of Science, Kyoto University, Series of Geology and Mineralogy 47: 61-133.

Teichert C., Kummel B. \& Sweet W.C. 1973. Permian-Triassic strata, Kuh-e-Ali Bashi, Northwestern Iran. Bulletin of the Museum of Comparative Zoology, Harvard University 145 (8): 359-472.

Voinova E.V., Kiparisova L.D. \& Robinson V.H. 1947. Klass Cephalopoda. Golovonogie., Atlas rukovodyashtchikh form iskopaemykh faun SSSR. VIII. Triasovaya sistema: 124-176, Moskva-Leningrad

Yang D.-z. \& Yang F. 1992. New materials of Late Permian ammonoids from Southeastern Hubei. Acta Palaeontologica Sinica 31: 595-604.

Yang F. 1987. Late Late Permian strata and their ammonoid zones in Southwest China. Earth ScienceJournal of Wuhan College of Geology 1985 (10): 129-144.

Zakharov Y.D. 1992. The Permo-Triassic boundary in the southern and eastern USSR and its intercontinental correlation. In: Sweet W.C., Zunyi Y., Dickins J.M. \& Hongfu Y. (eds) Permo-Triassic Events in the Eastern Tethys: Stratigraphy Classification and Relations with the Western Tethys: 46-55. Cambridge University Press, Cambridge. https://doi.org/10.1017/CBO9780511529498.006

Zakharov Y.D., Abnavi N.M., Yazdi M. \& Ghaedi M. 2010. New species of Dzhulfian (Late Permian) ammonoids from the Hambast Formation of Central Iran. Paleontological Journal 44: 614-621.

https://doi.org/10.1134/S003103011006002X 
Zakharov Y.D. \& Moussavi Abnavi N. 2013. The ammonoid recovery after the end-Permian mass extinction: evidence from the Iran-Transcaucasia area, Siberia, Primorye, and Kazakhstan. Acta Palaeontologica Polonica 58: 127-147.

Zhao J., Liang X. \& Zheng Z. 1978. Late Permian cephalopods from South China. Palaeontologia Sinica, Series B 12: 1-194.

Zheng Z. 1981. Uppermost Permian (Changhsingian) ammonoids from Western Guizhou. Acta Palaeontologica Sinica 20 (2): 107-114.

Manuscript received: 30 May 2021

Manuscript accepted: 13 August 2021

Published on: 27 October 2021

Topic editor: Christian de Muizon

Desk editor: Kristiaan Hoedemakers

Printed versions of all papers are also deposited in the libraries of the institutes that are members of the EJT consortium: Muséum national d'histoire naturelle, Paris, France; Meise Botanic Garden, Belgium; Royal Museum for Central Africa, Tervuren, Belgium; Royal Belgian Institute of Natural Sciences, Brussels, Belgium; Natural History Museum of Denmark, Copenhagen, Denmark; Naturalis Biodiversity Center, Leiden, the Netherlands; Museo Nacional de Ciencias Naturales-CSIC, Madrid, Spain; Real Jardín Botánico de Madrid CSIC, Spain; Zoological Research Museum Alexander Koenig, Bonn, Germany; National Museum, Prague, Czech Republic. 